Prepared in cooperation with the Triangle Area Water Supply Monitoring Project Steering Committee

\title{
Trends in Water Quality of Selected Streams and Reservoirs Used for Water Supply in the Triangle Area of North Carolina, 1989-2013
}
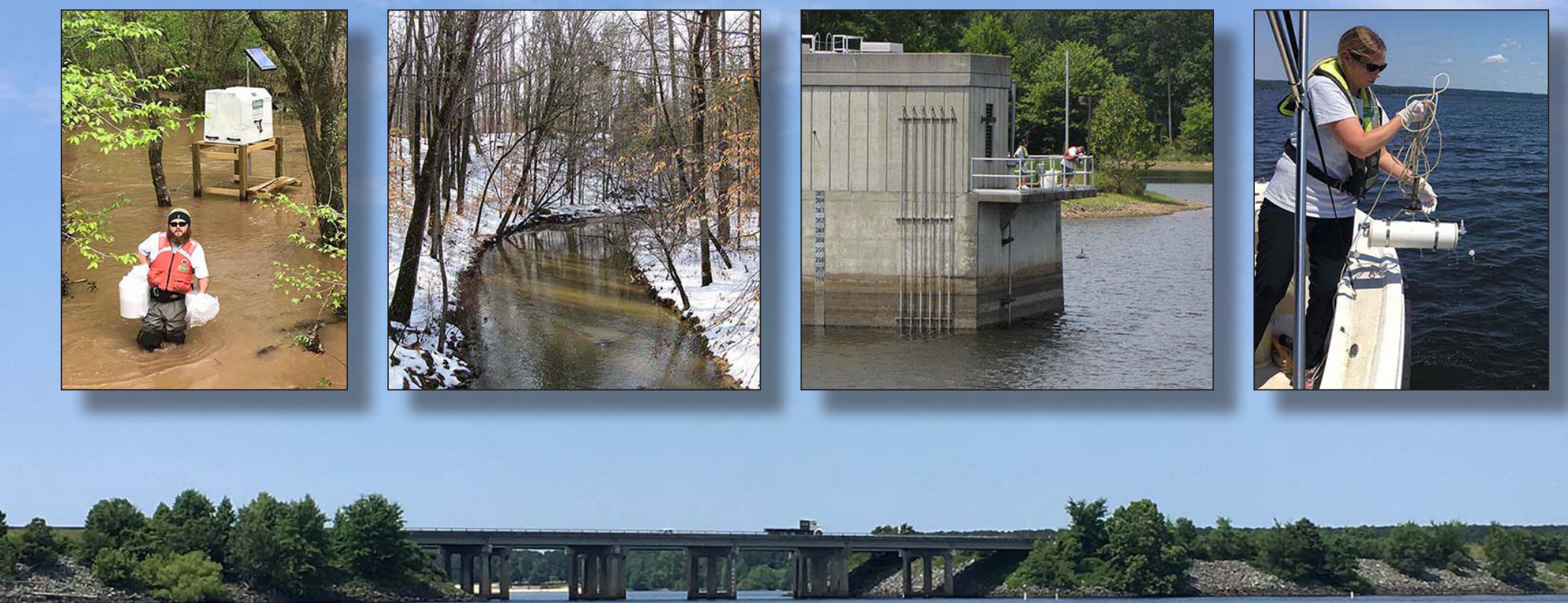

Scientific Investigations Report 2018-5077

U.S. Department of the Interior

U.S. Geological Survey 
Cover. Jordan Lake upstream from U.S. Highway 64 near Wilsonville, North Carolina, June 6, 2018 (photograph by Jen Schmitz, Triangle J Council of Governments).

Inset photographs. From left to right: U.S. Geological Survey (USGS) hydrologic technican retrieving high-flow samples at Northeast Creek near Genlee, NC, April 16, 2018 (photograph by Jessica Cain, USGS); Cane Creek near Orange Grove, NC, February 3, 2010 (photograph by Ryan Rasmussen, USGS); USGS hydrologic technicians collecting water-quality samples at Little River Reservoir near Bahama, NC, August 19, 2009 (photograph by Mary Giorgino, USGS); USGS hydrologic technician collecting samples at Jordan Lake near Wilsonville, NC, June 6, 2018 (photograph by Jen Schmitz, Triangle J Council of Governments). 


\section{Trends in Water Quality of Selected Streams and Reservoirs Used for Water Supply in the Triangle Area of North Carolina, 1989-2013}

By Mary J. Giorgino, Thomas F. Cuffney, Stephen L. Harden, and Toby D. Feaster

Prepared in cooperation with the Triangle Area Water Supply Monitoring Project Steering Committee

Scientific Investigations Report 2018-5077 


\title{
U.S. Department of the Interior \\ RYAN K. ZINKE, Secretary
}

\author{
U.S. Geological Survey \\ James F. Reilly II, Director
}

U.S. Geological Survey, Reston, Virginia: 2018

For more information on the USGS - the Federal source for science about the Earth, its natural and living resources, natural hazards, and the environment-visit https://www.usgs.gov or call 1-888-ASK-USGS.

For an overview of USGS information products, including maps, imagery, and publications,

visit https://store.usgs.gov.

Any use of trade, firm, or product names is for descriptive purposes only and does not imply endorsement by the U.S. Government.

Although this information product, for the most part, is in the public domain, it also may contain copyrighted materials as noted in the text. Permission to reproduce copyrighted items must be secured from the copyright owner.

Suggested citation:

Giorgino, M.J., Cuffney, T.F., Harden, S.L., and Feaster, T.D., 2018, Trends in water quality of selected streams and reservoirs used for water supply in the Triangle area of North Carolina, 1989-2013: U.S. Geological Survey Scientific Investigations Report 2018-5077, 67 p., https://doi.org/10.3133/sir20185077.

ISSN 2328-0328 (online) 


\section{Acknowledgments}

The long-term support of the Triangle Area Water Supply Monitoring Project Steering Committee is deeply appreciated. Committee members include representatives from Chatham and Orange Counties; the Towns of Apex, Cary, Hillsborough, and Morrisville; the City of Durham, and Orange Water and Sewer Authority. The Triangle J Council of Governments provides administrative and coordination support.

The authors wish to thank Aldo Vecchia, U.S. Geological Survey (USGS), for tireless assistance with trend analysis. Aldo Vecchia, Heather Welch, and Chad Wagner, USGS, provided insightful comments on the draft report. Ashlyann Arana-Morales, Kitty Kolb, and Silvia Terziotti, USGS, provided technical assistance with report preparation. Finally, the authors express sincere thanks to all field personnel and science-support staff who diligently collected and quality assured streamflow and water-quality data over the duration of the project since its inception in October 1988. 



\section{Contents}

Acknowledgments ……...................................................................................................................

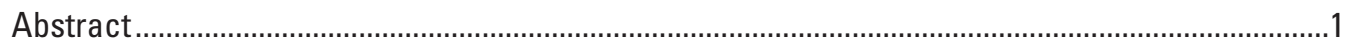

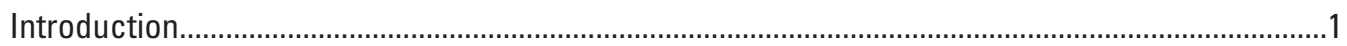

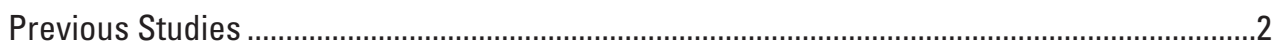

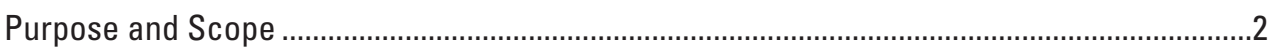

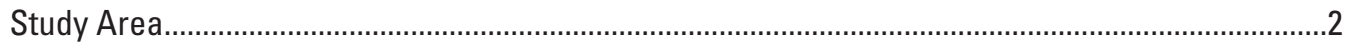

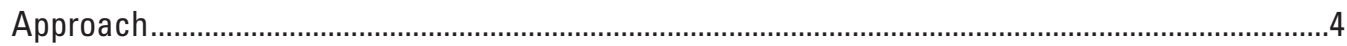

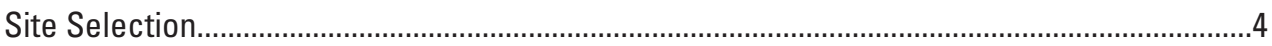

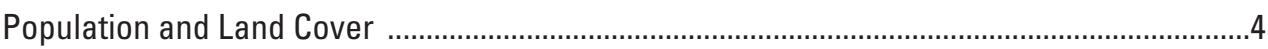

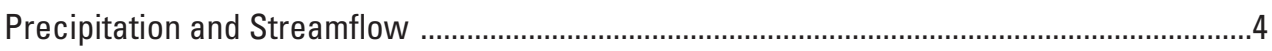

Water-Quality Data Compilation ............................................................................................

Time-Series Analysis for Water-Quality Trends......................................................................

Water-Quality Trends Related to Watershed Setting and Hydrologic Conditions ............................10

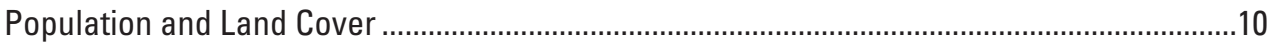

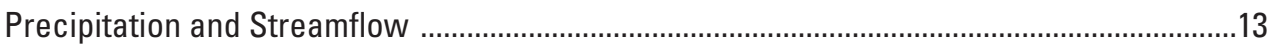

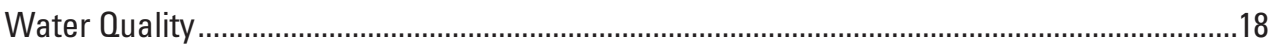

Specific Conductance and Major lons ..........................................................................18

Nutrients and Organic Carbon................................................................................... 45

Total Suspended Solids and Suspended Sediment in Streams ....................................54

Secchi Transparency and Chlorophyll $a$ in Lakes.........................................................59

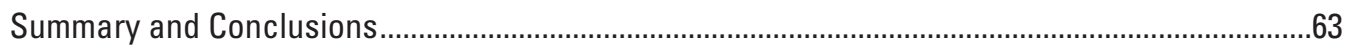

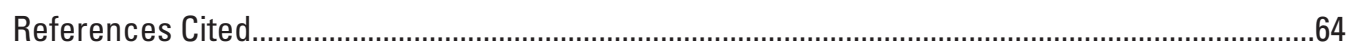

\section{Figures}

1. Map showing location of the Triangle Area Water Supply Monitoring Project trend sites in the upper Cape Fear and upper Neuse River Basins, North Carolina.........3

2-6. Graphs showing-

2. Population density for trend site watersheds in the Triangle area of North Carolina, 1990 and 2010

3. Percent change for generalized land-cover categories for trend site watersheds in the Triangle area of North Carolina from 1992 to 2011.

4. Annual precipitation in the Northern Piedmont and Central Piedmont climate divisions of North Carolina, 1989-2013, and long-term average precipitation at the Raleigh-Durham International Airport, 1981-2010

5. Duration of daily mean flow yields for sites $S 1, S 2, S 3$, and $S 4$ in the Neuse River Basin for the concurrent period October 1, 1988, to September 30, 2013.

6. Duration of daily mean flow yields for sites $S 5, S 6, S 7, S 8, S 9, S 100$, and $S 11$ in the Cape Fear River Basin and sites S9 and S100 in Morgan Creek for the concurrent period September 15, 1999, to September 30, 2013 
7-19. Maps and graphs showing trends at stream and lake sites assessed in the Triangle area of North Carolina, 1989-2013-

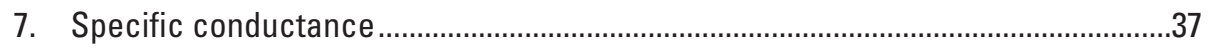

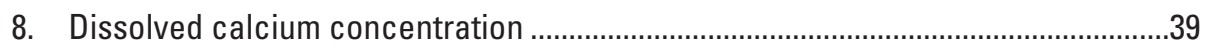

9. Dissolved magnesium concentration .................................................................40

10. Dissolved potassium concentration ...................................................................

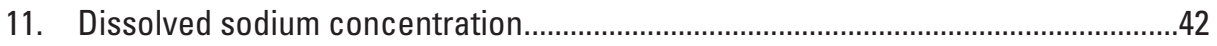

12. Dissolved chloride concentration ......................................................................

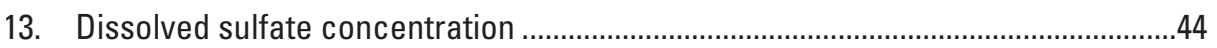

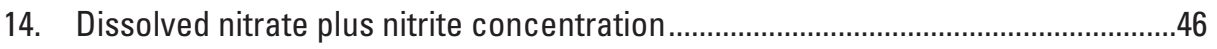

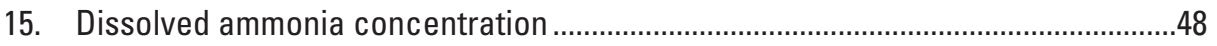

16. Total organic nitrogen concentration ................................................................

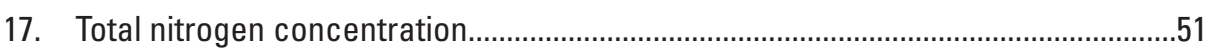

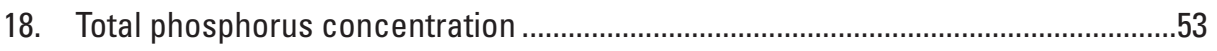

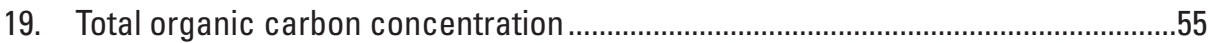

20. Map and graphs showing trends in suspended solids concentration at stream sites assessed in the Triangle area of North Carolina, 1989-2013 ...................................57

21. Map and graphs showing trends in suspended-sediment concentration at stream sites assessed in the Triangle area of North Carolina, 1989-2013......................58

22. Map and graphs showing trends in Secchi transparency at lake sites assessed in the Triangle area of North Carolina, 1993-2013...........................................................61

23. Map and graph showing trends in phytoplankton chlorophyll a concentration at lake sites assessed in the Triangle area of North Carolina, 1992-2013.

\section{Tables}

1. Stream and lake sites in the Triangle area, North Carolina, selected for trend analysis and sources of data....

2. Population density estimates for trend site watersheds in the Triangle area of North Carolina, 1990 and 2010, and change from 1990 to 2010

3. Generalized land-cover distribution for trend site watersheds in the Triangle area of North Carolina, circa 1992, circa 2011, and change from 1992 to 2011.

4. Flow-related watershed features and results of Kendall's tau statistical test for detection of monotonic trends in the annual minimum 7-day average flow, annual mean flow, and annual peak flow at streamflow-monitoring sites in the Triangle area of North Carolina, 1989-2013.

5. Statistical summary of water-quality properties and constituents aggregated for all stream and lake sites in the Triangle area of North Carolina for which trend assessments were conducted

6. Statistical summary of water-quality properties and constituents compiled for trend analysis in the Triangle area of North Carolina, by stream site

7. Statistical summary of water-quality properties and constituents compiled for trend analysis in the Triangle area of North Carolina, by lake site

8. Summary of trend results based on data collected during 1989-2013 for specific conductance, major ions, and nutrients at stream and lake sites assessed in the Triangle area of North Carolina 
9. Summary of trend results based on data collected during 1989-2013 for total suspended solids and suspended sediment at stream sites assessed in the Triangle area of North Carolina.

10. Summary of trend results based on data collected during 1992-2013 for Secchi transparency and chlorophyll $a$ at lake sites assessed in the Triangle area of North Carolina

\section{Conversion Factors}

U.S. customary units to International System of Units

\begin{tabular}{lcl}
\hline \multicolumn{1}{c}{ Multiply } & By & \multicolumn{1}{c}{ To obtain } \\
\hline inch (in.) & Length & \\
foot (ft) & 2.54 & centimeter $(\mathrm{cm})$ \\
\hline \multicolumn{2}{c}{ Area } & \\
\hline square mile $\left(\mathrm{mi}^{2}\right)$ & 0.3048 & heter $(\mathrm{m})$ \\
\hline \multicolumn{2}{c}{ hlow rate } & \\
\hline cubic foot per second per & 259.0 & cubic meter per second $\mathrm{per}$ \\
square mile $\left(\left[\mathrm{ft}^{3} / \mathrm{s}\right] / \mathrm{mi}^{2}\right)$ & 0.01093 & square kilometer $\left(\left[\mathrm{m}^{3} / \mathrm{s}\right] / \mathrm{km}^{2}\right)$ \\
\hline
\end{tabular}

Temperature in degrees Celsius $\left({ }^{\circ} \mathrm{C}\right)$ may be converted to degrees Fahrenheit $\left({ }^{\circ} \mathrm{F}\right)$ as follows:

$$
{ }^{\circ} \mathrm{F}=\left(1.8 \times{ }^{\circ} \mathrm{C}\right)+32 .
$$

\section{Datum}

Horizontal coordinate information is referenced to the North American Datum of 1983 (NAD 83).

\section{Supplemental Information}

Specific conductance is given in microsiemens per centimeter at 25 degrees Celsius $(\mu \mathrm{S} / \mathrm{cm}$ at $\left.25^{\circ} \mathrm{C}\right)$.

Concentrations of chemical constituents in water are given in either milligrams per liter (mg/L) or micrograms per liter $(\mu \mathrm{g} / \mathrm{L})$. 


\section{Abbreviations}

701

EPA

GIS

HPLC

lidar

MCFRBA

$\mathrm{N}$

NCDEO

NLCD 1992

NLCD 2011

NOAA

NPDES

NWIS

$P$

OWTREND

SEAKEN

STORET

TAWSMP

TKN

TON

UCFRBA

USGS

WRTDS

WWTP annual minimum 7-day average flow

U.S. Environmental Protection Agency

geographic information system

high-performance liquid chromatography

light detection and ranging

Middle Cape Fear River Basin Association

nitrogen

North Carolina Department of Environmental Quality

National Land Cover Dataset 1992

National Land Cover Database 2011

National Oceanic and Atmospheric Administration

National Pollutant Discharge Elimination System

National Water Information System

phosphorus

a parametric time-series model for detecting trends

Seasonal Kendall test

STOrage and RETrieval database

Triangle Area Water Supply Monitoring Project

total Kjeldahl nitrogen

total organic nitrogen

Upper Cape Fear River Basin Association

U.S. Geological Survey

Weighted Regressions on Time, Discharge, and Season

wastewater-treatment plant 


\title{
Trends in Water Quality of Selected Streams and Reservoirs Used for Water Supply in the Triangle Area of North Carolina, 1989-2013
}

\author{
By Mary J. Giorgino, Thomas F. Cuffney, Stephen L. Harden, and Toby D. Feaster
}

\section{Abstract}

As the population of the Triangle area in central North Carolina increases, the demand for good quality drinking water from streams and lakes within the upper Neuse and upper Cape Fear River Basins also increases. The Triangle area includes Raleigh, Cary, Research Triangle Park, Durham, Chapel Hill, and the surrounding communities. The U.S. Geological Survey examined temporal trends in water quality for 13 stream and 8 reservoir sites in the two basins on the basis of data collected during 1989-2013. Trends were analyzed by using a fitted time-series model that accommodated for shifting trends and variations in streamflow at multiple time scales. Seventeen water-quality properties and constituents were evaluated, including specific conductance and major ions, nutrients, and organic carbon. Suspended solids and suspended sediment were examined at stream sites; chlorophyll $a$ and Secchi transparency were examined at lake sites.

The investigation identified considerable changes in population, land cover, streamflow, and selected water-quality characteristics in the study area over the 25 -year period. Specific conductance and concentrations of calcium, magnesium, potassium, sodium, and chloride tended to increase throughout the study area. Area-wide increases were also observed for organic nitrogen. Trends for other water-quality constituents varied on a more site-specific basis because of local watershed influences such as changes to wastewatertreatment processes and substantial shifts from rural to urban land use. Water quality is influenced by multiple, often confounding factors, and thus may change in a manner that is not uniform over time. Long-term monitoring is critical for tracking these trends and ensuring resiliency of water supplies for the future. Results from this study may promote the understanding of water-quality response to a growing population and to land-cover changes and can assist waterresource managers in the Triangle area in tracking progress toward water-quality goals.

\section{Introduction}

The Triangle area of North Carolina includes the cities of Raleigh, Cary, Durham, and Chapel Hill; Research Triangle Park; and the surrounding communities. Ongoing growth in the Triangle area continues to increase the demand for local drinking-water supplies. At the same time, urbanization brings landscape changes that are likely to alter area hydrology and inputs of nutrients, sediment, and other water-quality constituents to lakes and rivers used as sources of drinking water. Several streams and lakes in the Triangle area are considered impaired because of degraded water quality (North Carolina Department of Environmental Quality, 2014), and all surface waters in the study area are designated "nutrient sensitive" (North Carolina Department of Environmental Quality, 2018). Raw water quality determines the type and level of water treatment needed to meet drinking-water standards. McDonald and others (2016) estimated that watershed degradation has led to increased water-treatment costs at 29 percent of cities globally, increasing costs, on average, by 53 percent for operation and maintenance and by 44 percent for replacement capital costs.

Recognizing the potential for ongoing population growth and landscape change to affect water-supply quality and quantity, State and local governments have committed to long-term monitoring and periodic assessments to protect these valuable resources. In 1988, several local governments joined to form the Triangle Area Water Supply Monitoring Project (TAWSMP) to systematically evaluate the quality of water-supply sources in the region. In partnership with the TAWSMP, the U.S. Geological Survey (USGS) has collected and analyzed water-quality samples from reservoirs and streams and has collected continuous records of streamflow in the study area for nearly 30 years. Data collected by USGS, State, and local monitoring programs form a valuable, longterm database for streamflow and water quality in the Triangle area. To date, however, the number of regional assessments conducted for long-term water-quality trends for area water supplies is limited. 
Understanding temporal changes is critical for documenting progress toward water-quality goals and informing water-supply planning and land-management decisions. Therefore, the USGS compiled publicly available streamflow and water-quality data and analyzed trends during the 25 -year period of 1989-2013 for streams and reservoirs in the Triangle area. Stream sites with long-term increases or decreases in flow were identified, and long-term increases or decreases in concentrations of selected water-quality constituents were identified for 13 stream sites and 8 reservoir sites.

\section{Previous Studies}

This study supplements a previous analysis of waterquality trends in the Triangle area of North Carolina for the period 1983-95 (Childress and Bathala, 1997). At a national scale, Sprague and others (2009) evaluated trends in nutrients in major rivers of the United States during 1993-2003, including two sites that were evaluated in the current study. Oelsner and others (2017) investigated trends in nutrients, sediment, ions, carbon, and other water-quality constituents in U.S. rivers and streams during 1972-2012, including five stream sites in the current study, by using the Weighted Regressions on Time, Discharge, and Season (WRTDS) method (Hirsch and others, 2010; Hirsch and De Cicco, 2015). Spruill and others (2006) studied trends of suspended sediment and nutrients in the upper Cape Fear River Basin during 1976-2004, including one site in the current study. Water-quality trends in selected Triangle area streams have also been evaluated periodically by the North Carolina Department of Environmental Quality (NCDEQ) as part of their river basin assessment program. The methods used for trend analysis in the current study differ from the methods used in previous investigations as discussed later in the report.

\section{Purpose and Scope}

This report presents a regional comparison of trends in water quality at selected water-supply streams and reservoirs in the Triangle area of North Carolina. Trends in water quality were related to trends in population density, land cover, and other relevant watershed characteristics. Watershed and streamflow characteristics, trend analysis methods, and factors potentially affecting trends are discussed.

Twenty-one sites (13 stream sites and 8 lake sites) were evaluated for water-quality trends during the 25 -year period of 1989-2013, hereafter referred to as "the trend period." The period of analysis was less than 25 years for some sites and (or) constituents because sufficient data were unavailable. The evaluation of trends generally involved a nested comparison of a 1-period trend model for the entire period with a 2-period trend model for "early" (1989-2001) and "late" (2002-13) subperiods to assess whether trend rates and directions shifted over time. Step-change functions were included in the trend models when known events contributed to abrupt changes in water quality. The trend models that best fit the data were selected for use in the regional evaluation. The magnitude of uptrends and downtrends was expressed as a percent change in concentration; the model-fitted median concentrations for beginning and ending years of the trend period also were reported.

Seventeen water-quality properties and constituents were examined for trends, although not all constituents were analyzed at all sites. Water-quality characteristics included specific conductance, dissolved ions, nutrients, total organic carbon, suspended sediment and (or) solids, chlorophyll $a$, and water clarity. Water-quality data were obtained from publicly available sources; specifically, the USGS National Water Information System (NWIS) and the U.S. Environmental Protection Agency (EPA) STOrage and RETrieval (STORET) database. Water-quality datasets that were used as input for the trend analyses are available from Cain and others (2018). Streamflow data from USGS streamgage-monitoring stations used in the trend analyses also were obtained from NWIS.

The trend-analysis approach used in this study allowed site-to-site comparisons throughout the study area during consistent time periods. A full discussion of site-specific trends was beyond the scope of this report; however, site-specific trends are presented when especially noteworthy.

\section{Study Area}

The study area is in the upper Neuse and upper Cape Fear River Basins in the Piedmont Physiographic Province of North Carolina (fig. 1). Characterized by low, rolling hills, the Piedmont extends westward to the Blue Ridge escarpment and eastward to the Coastal Plain. The geology of the region is complex, composed mainly of metamorphic and igneous rocks - primarily gneiss and schist - with granitic intrusions. The western part of the study area is generally located in the Carolina Slate Belt, which consists of heated and deformed volcanic and sedimentary rocks, including slate, gneiss, and metamudstone. The eastern part of the study area is in the Sanford-Durham Triassic Subbasin, which is dominated by claystones, siltstones, and other fine-grained sedimentary rocks (Bain and Brown, 1981; Daniel and Dahlen, 2002).

Sites selected for trend analysis were in Chatham, Durham, Orange, and Wake Counties. From 1990 to 2010, the population of these four counties increased 85 percentfrom 737,825 to $1,365,886$ people (Forstall, 1996; U.S. Census Bureau, 2017). The population of the same four counties is projected to increase by another 44 percent by the year 2030 (North Carolina Office of State Budget and Management, 2017).

Streams and reservoirs in the Triangle area are important water-supply sources and also support recreation, aquatic life, and other uses. Numerous efforts have been made through the years to protect these water supplies and ensure 


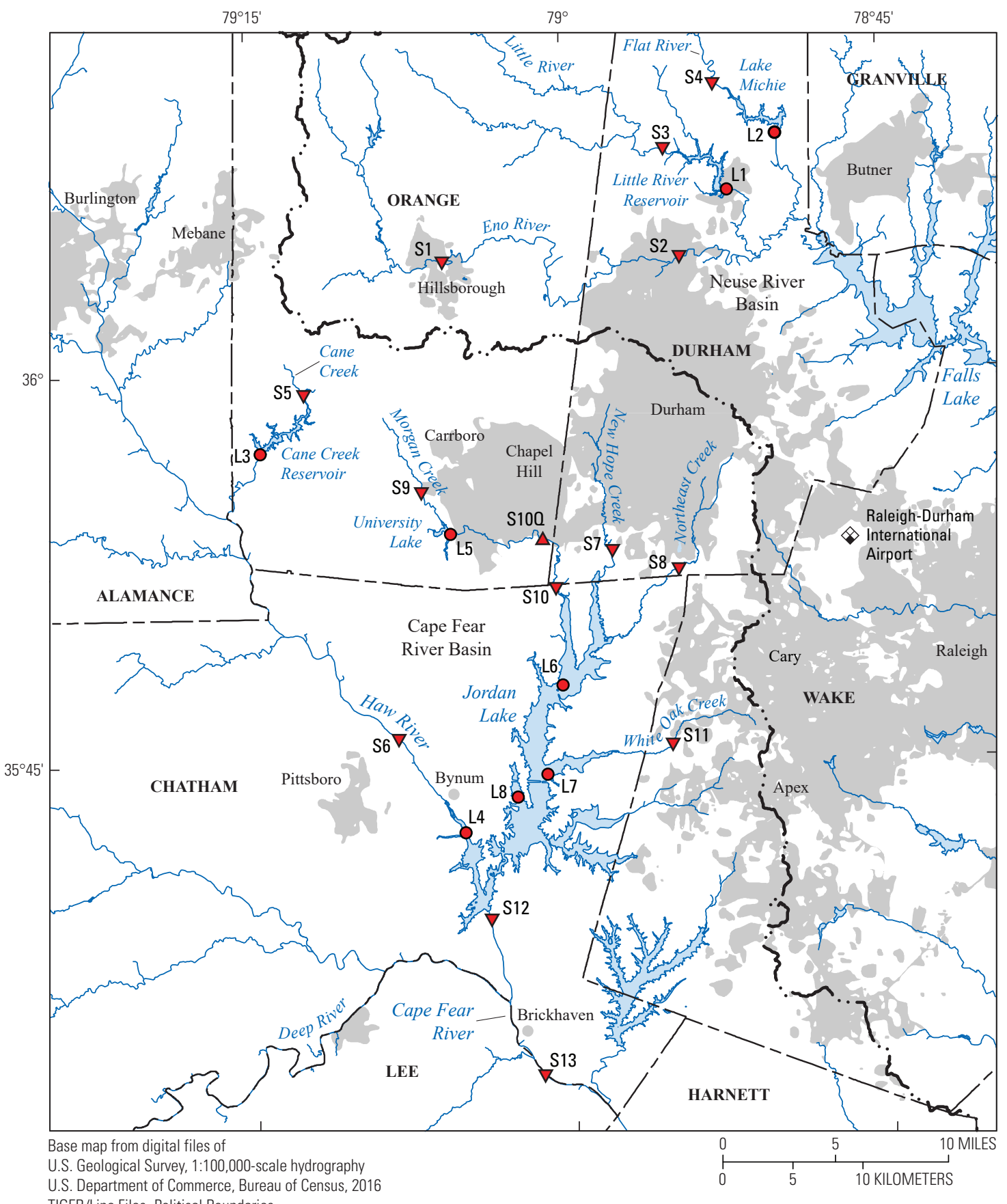

TIGER/Line Files- Political Boundaries

North Carolina Department of Transportation Municipal Boundaries
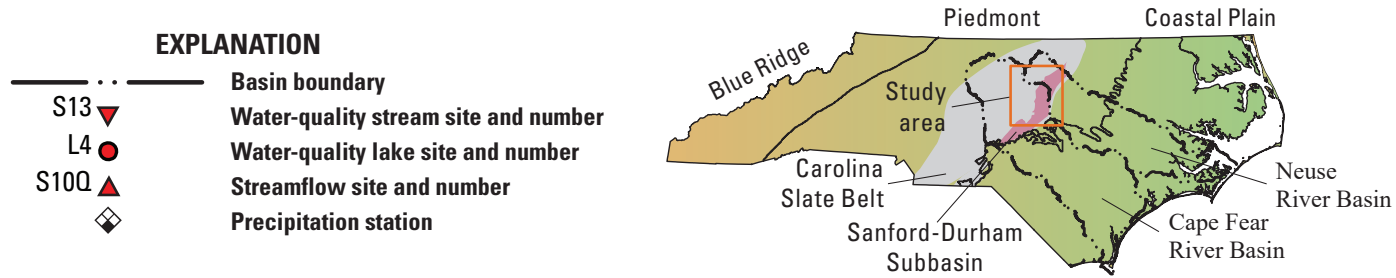

Figure 1. Location of the Triangle Area Water Supply Monitoring Project trend sites in the upper Cape Fear and upper Neuse River Basins, North Carolina. (Geologic belts shown in inset map were modified from Huffman and others, 2006.) 
their long-term sustainability and suitability for use. Various regulatory and voluntary efforts have been undertaken to manage inputs of pollutants to the reservoirs and their tributary streams. For example, a statewide phosphate-detergent ban was enacted in January 1988, which resulted in regionwide reductions of instream phosphorus concentrations (Childress and Bathala, 1997). Local governments have upgraded wastewater-treatment facilities to reduce both phosphorus and nitrogen levels, implemented land and water conservation practices, managed stormwater, and implemented best management practices to reduce runoff from development. Agricultural agencies and landowners have implemented best management practices to achieve sediment and nutrient-runoff reductions. Stream restoration projects have been constructed to restore more natural hydrology, and numerous watershed restoration plans have been adopted.

\section{Approach}

This section provides an overview of the sites selected for trend analysis and the methods used to compile watershed characteristics (land cover and population), hydrologic data (precipitation and streamflow), and water-quality data. Statistical methods used to evaluate trends in streamflow and water-quality constituents at the study sites are discussed.

\section{Site Selection}

The geographic extent of the TAWSMP network has varied over time. As previously stated, sites selected for the current trend analysis were in Orange, Durham, Chatham, and Wake Counties. The land area that drains to the selected sites extends farther upstream to the headwaters of the Neuse and Haw Rivers and downstream to the headwaters of Falls Lake and the Cape Fear River near Brickhaven. Stream sites, lake sites, and water-quality constituents were selected for trend analysis on the basis of available data.

In the Neuse River Basin, the four stream sites selected for water-quality trend analysis were located on the Flat, Little, and Eno Rivers, and the two lake sites were in Lake Michie and Little River Reservoir. In the Cape Fear River Basin, the nine stream sites selected for water-quality trend analysis were located on the Cane, Morgan, New Hope, Northeast, and White Oak Creeks and the Haw and Cape Fear Rivers, and the six lake sites were in Cane Creek Reservoir, University Lake, and Jordan Lake (fig. 1; table 1). Morgan Creek near Farrington (site S10) was a water-quality sampling site with no streamflow gage; thus, Morgan Creek near Chapel Hill (site S10Q) was used as the source of streamflow data for site S10.

\section{Population and Land Cover}

Watershed boundaries and contributing drainage areas for the sites were determined with the USGS StreamStats application developed for North Carolina (https://streamstats. usgs.gov/ss/; Weaver and others, 2012). These features were calculated by using a 30 -foot (ft) by 30 -ft light detection and ranging (lidar)-derived digital elevation model. Drainage areas for the trend sites ranged in size from 7.54 to 3,160 square miles $\left(\mathrm{mi}^{2}\right.$; table 1). Note that drainage area delineation was not applicable for Jordan Lake at Bells Landing (site L8), because the site is in a cove of Jordan Lake. Jordan Lake was impounded in 1982, and water quality at site L8 primarily depends on upstream conditions in the New Hope Creek arm.

Population statistics were compiled by using geographic information system (GIS) processes. Watershed boundaries were intersected with 1990 and 2010 U.S. Census block datasets. The proportion of each census block's area within each watershed was calculated. Each watershed's population was computed as the area-weighted sum of the census block populations within the watershed boundary. Population density was obtained by dividing the total population by the drainage area.

Land-cover data for the trend site watersheds were compiled by using the StreamStats application. The 1992 and 2011 National Land Cover Datasets (NLCD 1992 and NLCD 2011) were used to characterize conditions near the beginning and end of the 1989-2013 trend period for each site. Mapping methods differ for the two datasets; therefore, comparisons should be interpreted broadly. The NLCD 1992 was based primarily on circa 1992 Landsat Thematic Mapper data (Vogelmann and others, 2001) and used a 21-class land-cover classification scheme. The NLCD 2011 was based primarily on circa 2011 Landsat satellite data and included a 16-class land-cover classification scheme (Homer and others, 2015). For this report, detailed land-cover classes were aggregated into three generalized categories - developed, agricultural, and forested/other, which included water and wetlands.

\section{Precipitation and Streamflow}

Although many factors influence streamflow, including basin size and slope, interaction with groundwater, land cover, geology, dams, and water-supply withdrawals, streamflow amounts are determined primarily by the amount of precipitation that falls in a watershed. Regional precipitation data for the Northern Piedmont and Central Piedmont climate divisions of North Carolina were obtained from the National Oceanic and Atmospheric Administration (NOAA, 2018). The Northern Piedmont climate division includes Orange and Durham Counties; the Central Piedmont climate division 
Table 1. Stream and lake sites in the Triangle area, North Carolina, selected for trend analysis and sources of data.

[no., number; USGS, U.S. Geological Survey; mi², square mile; NCDEQ, North Carolina Department of Environmental Quality; AMS, Ambient Monitoring System; NC, North Carolina; na, not applicable; SR, Secondary Road; UCFRBA, Upper Cape Fear River Basin Association; USACE, U.S. Army Corps of Engineers; MCFRBA, Middle Cape Fear River Basin Association. Gray shading indicates sites in the Neuse River Basin; unshaded rows represent sites in the Cape Fear River Basin]

\begin{tabular}{|c|c|c|c|c|c|c|c|}
\hline $\begin{array}{l}\text { Map no. } \\
\text { (fig. 1) }\end{array}$ & $\begin{array}{l}\text { USGS } \\
\text { station no. }\end{array}$ & USGS station name & $\begin{array}{c}\text { Drainage } \\
\text { area } \\
\left(\mathrm{mi}^{2}\right)\end{array}$ & $\begin{array}{l}\text { Source of } \\
\text { streamflow } \\
\text { data }\end{array}$ & $\begin{array}{c}\text { Source of } \\
\text { water-quality } \\
\text { data }\end{array}$ & $\begin{array}{l}\text { NCDEO AMS } \\
\text { station no. }\end{array}$ & $\begin{array}{l}\text { NCDEO AMS } \\
\text { station name }\end{array}$ \\
\hline \multicolumn{8}{|c|}{ Stream sites } \\
\hline S1 & 02085000 & Eno River at Hillsborough, NC & 66.0 & USGS gage at site & USGS & na & na \\
\hline S2 & 02085070 & Eno River near Durham, NC & 141 & USGS gage at site & USGS, NCDEQ & J0770000 & $\begin{array}{l}\text { Eno River at US } 501 \\
\text { near Durham }\end{array}$ \\
\hline S3 & 0208521324 & $\begin{array}{l}\text { Little River at SR } 1461 \text { near Orange } \\
\text { Factory, NC }\end{array}$ & 78.2 & USGS gage at site & USGS, NCDEQ & J0820000 & $\begin{array}{l}\text { Little River at SR } 1461 \\
\text { near Orange Factory }\end{array}$ \\
\hline S4 & 02085500 & Flat River at Bahama, NC & 149 & USGS gage at site & USGS, NCDEQ & J1070000 & $\begin{array}{l}\text { Flat River at SR } 1614 \\
\text { near Quail Roost }\end{array}$ \\
\hline S5 & 02096846 & Cane Creek near Orange Grove, NC & 7.54 & USGS gage at site & USGS & na & na \\
\hline S6 & 02096960 & Haw River near Bynum, NC & 1,275 & USGS gage at site & $\begin{array}{l}\text { USGS, NCDEQ, } \\
\text { UCFRBA }\end{array}$ & B2100000 & $\begin{array}{l}\text { Haw River at SR } 1713 \\
\text { near Bynum }\end{array}$ \\
\hline S7 & 02097314 & New Hope Creek near Blands, NC & 75.9 & USGS gage at site & $\begin{array}{l}\text { USGS, NCDEQ, } \\
\text { UCFRBA }\end{array}$ & B3040000 & $\begin{array}{l}\text { New Hope Creek at } \\
\text { SR } 1107 \text { near Blands }\end{array}$ \\
\hline S8 & 0209741955 & $\begin{array}{l}\text { Northeast Creek at SR } 1100 \text { near Genlee, } \\
\text { NC }\end{array}$ & 21.1 & USGS gage at site & USGS, NCDEQ & B3660000 & $\begin{array}{l}\text { Northeast Creek at } \\
\quad \text { SR } 1100 \text { near Nelson }\end{array}$ \\
\hline S9 & 02097464 & Morgan Creek near White Cross, NC & 8.35 & USGS gage at site & USGS & na & na \\
\hline S10 & 02097521 & Morgan Creek near Farrington, NC & 46.0 & $\begin{array}{c}\text { USGS station } \\
02097517\end{array}$ & $\begin{array}{l}\text { USGS, NCDEQ, } \\
\text { UCFRBA }\end{array}$ & B3900000 & $\begin{array}{l}\text { Morgan Creek at SR } \\
1726 \text { near Farrington }\end{array}$ \\
\hline S11 & 0209782609 & $\begin{array}{l}\text { White Oak Creek at mouth near Green } \\
\text { Level, NC }\end{array}$ & 11.9 & USGS gage at site & USGS & na & na \\
\hline $\mathrm{S} 12$ & 02098198 & $\begin{array}{l}\text { Haw River below B. Everett Jordan Dam } \\
\text { near Moncure, NC }\end{array}$ & 1,689 & $\begin{array}{l}\text { USACE Jordan } \\
\text { Lake dam } \\
\text { releases }\end{array}$ & USGS, NCDEQ & B4050000 & $\begin{array}{l}\text { Haw River below Jordan } \\
\text { Dam near Moncure }\end{array}$ \\
\hline S13 & 0210215985 & $\begin{array}{l}\text { Cape Fear River at State Highway } 42 \text { near } \\
\text { Brickhaven, NC }\end{array}$ & 3,160 & $\begin{array}{l}\text { USGS stations } \\
02098206 \text { and } \\
02100500\end{array}$ & $\begin{array}{l}\text { USGS, NCDEQ, } \\
\text { MCFRBA }\end{array}$ & B6160000 & $\begin{array}{l}\text { Cape Fear River at } \\
\text { NC } 42 \text { near Corinth }\end{array}$ \\
\hline \multicolumn{8}{|c|}{ Lake sites } \\
\hline L1 & 0208524845 & $\begin{array}{l}\text { Little River Reservoir at Dam near } \\
\text { Bahama, NC }\end{array}$ & 97.7 & $\begin{array}{l}\text { USGS station } \\
0208521324\end{array}$ & USGS & na & na \\
\hline L2 & 02086490 & Lake Michie at Dam near Bahama, NC & 167 & $\begin{array}{l}\text { USGS station } \\
02085500\end{array}$ & USGS & na & na \\
\hline L3 & 0209684980 & $\begin{array}{l}\text { Cane Creek Reservoir at Dam near White } \\
\text { Cross, NC }\end{array}$ & 31.4 & $\begin{array}{c}\text { USGS station } \\
02096846\end{array}$ & USGS & na & na \\
\hline L4 & 0209699999 & $\begin{array}{l}\text { Jordan Lake, Haw River arm near Hanks } \\
\text { Chapel, NC }\end{array}$ & 1,303 & $\begin{array}{l}\text { USGS station } \\
02096960\end{array}$ & USGS & na & na \\
\hline L5 & 0209749990 & $\begin{array}{l}\text { University Lake at Intakes near Chapel } \\
\text { Hill, NC }\end{array}$ & 30.0 & $\begin{array}{c}\text { USGS station } \\
02097464\end{array}$ & USGS & na & na \\
\hline L6 & 0209768310 & Jordan Lake at Buoy 12 at Farrington, NC & 231 & $\begin{array}{l}\text { USGS stations } \\
02097314 \text { and } \\
02097517\end{array}$ & USGS & na & na \\
\hline L7 & 0209799150 & $\begin{array}{l}\text { Jordan Lake above U.S. Highway } 64 \text { at } \\
\text { Wilsonville, NC }\end{array}$ & 285 & $\begin{array}{l}\text { USGS stations } \\
02097314 \text { and } \\
02097517\end{array}$ & USGS & na & na \\
\hline L8 & 0209801100 & $\begin{array}{l}\text { Jordan Lake at Bells Landing near } \\
\text { Griffins Crossroads, NC }\end{array}$ & na & $\begin{array}{l}\text { USGS stations } \\
02097314 \text { and } \\
02097517\end{array}$ & USGS & na & na \\
\hline
\end{tabular}


Trends in Water Quality of Streams and Reservoirs Used for Water Supply in the Triangle Area of NC, 1989-2013

includes Chatham and Wake Counties. For comparison, the long-term, annual average precipitation data for the RaleighDurham International Airport (fig. 1) also were obtained from NOAA (2017).

The USGS operates a network of streamflow-gaging stations throughout the study area. For each stream-monitoring site (table 1), daily mean streamflow values were obtained from the USGS NWIS database (U.S. Geological Survey, 2014). Streamflow values for two water-quality sites (S10 and S13) were computed by using data from nearby upstream gages (table 1). In addition, daily records of releases from the Jordan Lake dam were obtained from the U.S. Army Corps of Engineers (2018) to estimate flows at the Haw River below Jordan dam (site S12; table 1).

Flow was not measured at lake sites; however, the waterquality trend analysis technique used in this study required the input of daily flow data, or a representative surrogate, for all sites. Therefore, flow records from upstream USGS streamgages were used to construct surrogate daily-flow values for each lake site (table 1).

Kendall's tau test (Helsel and Hirsch, 2002) was used to assess trends in streamflow at USGS streamflow-gaging stations in the upper Neuse and upper Cape Fear River Basins. The period of time for which streamflow records were available varied considerably among sites, ranging from 15 to 90 years. To facilitate comparisons, however, trends in streamflow were evaluated for the period 1989-2013 at all sites except White Oak Creek (S11), where streamflow monitoring began in 1999. To assess the full range of flows, trend tests were performed on three flow statistics: annual minimum 7-day average flow (7Q1); annual mean flow; and annual peak flow. Available approved data were used through March 31, 2014, which corresponds with the 2013 climatic year. Climatic year is the annual period from April 1 through March 31 that conventionally is used by the USGS for analysis of low-flow statistics. The USGS uses the annual period from October 1 through September 30 (water year) for analysis of annual mean and peak flow statistics.

To illustrate how streamflow characteristics varied among sites, durations of daily flow were computed for the four Neuse River Basin stations for the concurrent period of record from October 1, 1988, to September 30, 2013. Likewise, durations of daily-flow yields were computed for seven Cape Fear River Basin stations for the concurrent period of record from September 15, 1999, to September 30, 2013 (the period for which streamflow data were available for all seven sites). To eliminate differences due to drainage area size, the duration flow for a site was divided by the drainage area of the site, resulting in flow yield in cubic feet per second per square mile.

\section{Water-Quality Data Compilation}

Water-quality monitoring has been conducted at the study sites by multiple agencies, including the USGS, the NCDEQ, and two regional monitoring coalitions. Depending on the individual study site, data were compiled from one to three sources (table 1). USGS data were retrieved from NWIS (U.S. Geological Survey, 2014). The NCDEQ monitors nine of the same USGS stream sites as part of its Ambient Monitoring System. The NCDEQ site identification numbers and names that correspond to the USGS sites are listed in table 1. The Upper Cape Fear River Basin Association (UCFRBA) and the Middle Cape Fear River Basin Association (MCFRBA) monitor water quality at three and one TAWSMP sites, respectively, under Memorandums of Agreement with the NCDEQ and adhere to the NCDEQ site-numbering scheme (table 1). Data from these two coalitions are quality assured and uploaded to STORET by the NCDEQ. Water-quality data for the NCDEQ, UCFRBA, and MCFRBA monitoring stations were retrieved from the STORET database (U.S. Environmental Protection Agency, 2014). All water-quality data used for the trend analysis were previously quality assured by the source agencies (USGS or NCDEQ) prior to being downloaded from the NWIS or STORET databases.

In contrast to the stream sites, only USGS water-quality data were used for trend analysis at lake sites. The USGS sampled lake sites at multiple depths; however, only upper/photic zone samples were included in the trend analysis. Although the NCDEQ also sampled many of the TAWSMP lakes through its Ambient Lakes Monitoring program, NCDEQ sampling historically focused on one season of the year (summer) and was conducted once every 5 years in accordance with a river-basin rotational schedule. The NCDEQ sampled Jordan Lake more frequently; however, sampling locations generally did not correspond to TAWSMP trend sites.

Properties and constituents selected for trend analysis at stream and lake sites included specific conductance, major ions (calcium, magnesium, potassium, sodium, chloride, and sulfate), nutrients (nitrate plus nitrite [hereafter referred to as nitrate], ammonia, total organic nitrogen, total nitrogen, and total phosphorus), and total organic carbon. In addition, suspended solids and suspended-sediment data were available for stream sites. Chlorophyll $a$ and Secchi depth measurements of water transparency were monitored only at lake sites.

Water-quality data for the 13 stream- and 8 lake-monitoring sites were compiled for the period January 1989 through December 2013. For stream sites sampled by more than one agency, analytical results for multiple samples occasionally were available on the same date. In these cases, only the sample with the most complete set of analytical results was retained. Most sites had water-quality data for the entire 25-year period of record, but eight sites had shorter periods of record. Water-quality data began in 1990 for site S1, in 1991 for sites L4, L7, and L8, in 1993 for site L6, and in 2000 for site S11. Data for site S4 ended in 2011. At site S13, data for major ions ended in 2003, and data for all other constituents ended in 2012.

As might be expected, different stream-sampling methods were used during the trend period, both among and within agencies. The USGS generally collected cross-sectional, 
depth-integrated composite samples from streams, but occasionally automated samplers were used to collect highflow samples from a single point in a stream. The NCDEQ, UCFRBA, and MCFRBA typically collected samples from a single point at mid-channel or at the point of greatest flow. Sampling-method differences may have influenced water-quality results, particularly for unfiltered constituents that include particulate matter, such as total nitrogen and total phosphorus. For trend analysis, results were not differentiated on the basis of sampling method, and the data were assumed to be representative and comparable. Laboratory analytical methods and reporting levels evolved during the trend period as well. Analytical approaches for data with multiple reporting levels are discussed later in this report.

The compiled data were reviewed to identify questionable results and obvious outliers, which were then excluded from the final trend-analysis datasets. Reviews included examining nitrogen-fraction ratios, data plots, plots of streamflow versus constituent, and residuals plots from exploratory trend analysis. An example of questionable data included one sample from site S10 and another from site S12 with reported ammonia concentrations that were greater than the concentrations reported for ammonia plus organic nitrogen (theoretically impossible). In another case, one very high concentration of total suspended solids was reported at Eno River near Durham (site S2) during extremely low-flow conditions, which suggested that the sampling device may have contacted the river bottom and thus contaminated the sample. Clear outliers that likely represented episodic events also were eliminated from the trend datasets. For example, one sample collected at Eno River at Hillsborough (site S1) had an unusually high sulfate concentration of 170 milligrams per liter $(\mathrm{mg} / \mathrm{L})$ that also contributed to an unusual specific conductance value of 304 microsiemens per centimeter $(\mu \mathrm{S} / \mathrm{cm})$. The data were valid but highly atypical for this site; therefore, these two values were excluded from the trend analysis.

Retrievals of water-quality data included remark codes associated with analytical results, such as "less than" $(<)$ censored values. During February through July 2001, the NCDEQ laboratory implemented changes to internal qualityassurance practices and analytical methods that resulted in substantial, but temporary, increases in analytical reporting levels for nutrient constituents (North Carolina Department of Environmental Quality, 2017). Retention of these data would have artificially inflated levels used to re-censor data during the trend analysis; therefore, data for samples collected by NCDEQ during this period were excluded.

The USGS lake-sampling methods for chlorophyll $a$ changed in 1992. Prior to 1992, samples were collected at 1 meter $(\mathrm{m})$ below the water surface by using a grab-sampling device. Beginning in 1992, chlorophyll $a$ samples were collected throughout the euphotic zone, operationally defined as the depth equal to twice the Secchi transparency depth, by using a depth-integrating sampler. The change to photic-zone sampling occurred to align USGS and NCDEQ lakesampling protocols and thereby improve data comparability
(Oblinger, 2004). Shifts in chlorophyll $a$ concentrations that coincided with this method change were evident at several lake sites; therefore, pre-1992 data were excluded from the trend analysis.

For nutrients, all monitoring agencies reported concentrations of the various nitrogen fractions in milligrams per liter as nitrogen $(\mathrm{N})$ and concentrations of total phosphorus in milligrams per liter as phosphorus (P). Analytical results for USGS nutrient samples included concentrations of total ammonia plus organic $\mathrm{N}$, filtered ammonia, filtered nitrate plus nitrite, total N, and total P. Nutrient results from NCDEQ, UCFRBA, and MCFRBA were based on unfiltered samples and therefore included concentrations of total ammonia plus organic $\mathrm{N}$ (also referred to as total Kjeldahl nitrogen [TKN]), total ammonia, total nitrate plus nitrite, and total $\mathrm{P}$. Concentrations reported for total ammonia and total nitrate plus nitrite were assumed to be equivalent to concentrations of dissolved ammonia and dissolved nitrate plus nitrite, respectively, because these constituents are present in water only in dissolved form. In this study, trends were analyzed for the following nitrogen fractions: nitrate plus nitrite, hereafter referred to as "nitrate," ammonia, total organic $\mathrm{N}$, and total $\mathrm{N}$.

Values for total organic $\mathrm{N}$ and total $\mathrm{N}$ were computed by using concentrations reported for the aforementioned, directly measured $\mathrm{N}$ fractions. Total organic $\mathrm{N}$, which includes both particulate and dissolved forms, was computed by subtracting ammonia from total ammonia plus organic N. When one or both of these constituents was left-censored (less than the reporting level), a "<" remark code was or was not applied to the computed total organic $\mathrm{N}$ concentration as follows:

- If total ammonia plus organic $\mathrm{N}$ was left-censored, the remark code was carried forward with the computed value for total organic $\mathrm{N}$ regardless of whether ammonia was censored or uncensored.

- In those cases where total ammonia plus organic $\mathrm{N}$ was uncensored and ammonia was left-censored, ammonia typically represented a small fraction, less than 20 percent, of the total ammonia plus organic $\mathrm{N}$ values; thus, the remark code was not applied to the computed total organic $\mathrm{N}$ values.

Values of total $\mathrm{N}$ were computed by summing concentrations for total ammonia plus organic $\mathrm{N}$ and nitrate plus nitrite. When one or both of these constituents was left-censored, the " $<$ " remark code was or was not applied to the computed total $\mathrm{N}$ concentration as follows:

- If both total ammonia plus organic $\mathrm{N}$ and nitrate plus nitrite were left-censored, then the remark code was carried forward with the computed value for total $\mathrm{N}$.

- If only one of the constituents was left-censored and its value represented 40 or more percent of the computed value, the remark code also was assigned to the computed total $\mathrm{N}$ value; otherwise, the remark code was not applied. 
The final datasets used for trend analysis contained more than 47,000 water-quality observations and are available from Cain and others (2018). Statistical summaries were useful for describing and comparing general water-quality characteristics among sites and provided information relevant for analyzing and interpreting trends. The total number of observations, number and percentage of censored observations, mean and standard deviation, and minimum, maximum, and median values were computed for the aggregated stream data, the aggregated lake data, and each site-constituent pairing. Summary statistics for constituents with censored data were determined by use of the Kaplan-Meier technique (Helsel, 2005). Although the concentration data were assumed to have a lognormal distribution, this technique provided unbiased estimates of percentiles, median, and interquartile range for a variety of data distributions, even those that were not lognormal. The percentage of censored data in a trend dataset was particularly important, because the trend analysis could fail to run or produce misleading results when used to analyze highly censored datasets. For this reason, trend results were not presented for station-constituent datasets that contained more than 20 percent censored data. Of 232 site-constituent pairings, 18 had high censoring that precluded trends analysis. This threshold was exceeded for three water-quality constituents: ammonia at five stream sites (S2, S3, S4, S5, and S6) and four lake sites (L5, L6, L7, and L8); total suspended solids at two stream sites (S3 and S6); and nitrate at seven lake sites (L1, L2, L3, L5, L6, L7, and L8).

\section{Time-Series Analysis for Water-Quality Trends}

Trends in 17 water-quality properties and constituents were analyzed on a site-by-site basis. Increases and decreases over time were expressed as both percentage difference and magnitude of change in annual fitted-median concentrations from the beginning to the ending year of the trend period. Trends were identified as statistically significant or nonsignificant on the basis of a widely used convention of $\mathrm{p}$-value less than 0.05 . Conventional tests of significance are informative; however, the choice of a significance level is somewhat discretionary. Therefore, the direction and magnitude of change were provided for all reported trends regardless of the p-value.

The QWTREND program, a parametric statistical time-series model for detecting trends developed by the USGS (Vecchia, 2000, 2003, 2004a, 2004b, 2005), was used to determine whether statistically significant trends existed for the 17 water-quality properties and constituents examined in this study. QWTREND takes into consideration the relation between a property or constituent concentration and both concurrent (same day as concentration sample) and lagged (days leading up to the concentration sample) flow at multiple time scales (annual, seasonal, and daily). Characterizing flowrelated variability at multiple time scales is important because many water-quality properties and constituent concentrations may depend on streamflow in complex ways that cannot be adequately accounted for by using a regression model relating concentration only with concurrent streamflow. Accounting for as much flow-related variability as possible increases the ability to detect trends in concentration independent of trends in flow arising from long- and short-term climatic variation.

QWTREND uses a time-series analysis to express log-transformed constituent concentration in terms of additive components consisting of a trend, flow-related variability, and serially correlated errors:

$$
\log (C)=M_{C}+A N N_{C}+S E A S_{C}+H F V_{C}+T R E N D_{C}
$$

where

$\log$ denotes the base-10 logarithm;

$C$ is the concentration, in milligrams or micrograms per liter;

$M_{C} \quad$ is the long-term mean of the $\log _{10}$-transformed concentration;

$A N N_{C} \quad$ is the annual concentration variability;

$S E A S_{C} \quad$ is the seasonal concentration variability;

$H F V_{C}$ is the high-frequency variability of the concentration; and

TREND $_{C} \quad$ is the concentration trend (dimensionless).

$A N N_{C}, S E A S_{C}$, and $H V F_{C}$ represent natural variability in concentration for different time scales. $A N N_{C}$ is an estimate of the interannual variability in concentration that can be attributed to long-term variability in streamflow. For example, the proportion of surface runoff to base flow in streams is affected by extended dry and wet periods, which result in changes to stream water quality. $S E A S_{C}$ is an estimate of the variability in concentration that can be attributed to seasonal fluctuations in streamflow or factors other than streamflow, such as snowmelt, water temperatures, fertilizer applications, or road deicing. Both $A N N_{C}$ and $S E A S_{C}$ depend on concurrent and lagged daily streamflow (Vecchia, 2005, appendix 1). $H F V_{C}$ estimates the variability in concentration over time intervals shorter than a season (for example, several days or weeks), such as daily changes in weather that may cause variability in streamflow and water quality. $H F V_{C}$ depends on both concurrent and lagged daily streamflow and, in addition, accounts for potential serial correlation between concentration samples separated by short time intervals (several days to several months) (Vecchia, 2005, appendix 1). TREND ${ }_{C}$ estimates long-term systematic changes in water-quality concentration that are unrelated to streamflow, such as a change in human activities. Step (abrupt), monotonic (gradual upward or downward), or cyclic trends are possible. Trends can persist for a short time before ending or reversing direction. In general, TREND ${ }_{C}$ can consist of any linear combination of piecewise monotonic trends, step trends, or other more complicated trends that may be considered, depending on the objectives of the trend analysis and the adequacy of the data (for example, sampling frequency, record length) for determining the trend coefficients. 
The QWTREND program uses Gaussian maximum likelihood estimation to fit the model parameters, choose the best trend model, and determine the significance levels (p-values) associated with the trends. For this study, QWTREND was used to compare among nested models (null [no trend], 1-period trend, and 2-period trend), and statistically significant trends were identified when the probability of a Type I error was less than 5 percent $(\alpha=0.05)$. Generalized likelihood ratio tests (Vecchia, 2005, appendix 1) were used to determine if the 2-period trend model was a significantly better fit than the 1-period trend model. Additional step trends were included in certain cases, when appropriate. The magnitude of uptrends and downtrends was expressed as a percent change in concentration; the annual model-fitted median concentrations for beginning and ending years of the trend period also were reported.

QWTREND analysis uses nonlinear optimization, is computation-intensive, requires care in fitting the models and verifying assumptions about the model and data, and cannot assess highly censored datasets. For this study, the following guidelines were used for including a constituent in a QWTREND analysis:

- at least 15 years of continuous daily streamflow data

- at least 1 year of flow data prior to the collection of the first water-quality sample

- at least 10 years of water-quality data, not necessarily consecutive

- at least 4 samples per year

- at least 15 samples in each 3-month season (January-March, April-June,...)

- less than 20 percent censored data

QWTREND replaced left-censored (“<”) values with half of the largest censored value in the dataset for the constituent and site. If an uncensored value was less than half of the largest censored value, it was also censored at that value. A time step of 3 samples per month (36 samples per year) was used in the QWTREND analyses. Many of the concentration values were missing, which is permissible, but streamflow values were available. The three samples per month represented early (1st-10th), middle (11th-20th), or late (21st-31st) periods in the month. If a water-quality constituent was measured once in an interval, the daily mean streamflow value that corresponded to the water-quality measurement date was used for that period. If a water-quality constituent was measured more than once in an interval, the daily mean streamflow value closest to the middle of the interval was used. Likewise, if the waterquality constituent was not measured in an interval, streamflow for the middle of the interval was used (that is, the 5th, 15th, or 25th of the month for the early, middle, or late period in the month, respectively).
Selection of trend analysis time periods was important because results are dependent on how the time periods are structured. Factors considered in the selection of trend analysis time periods included the timing of known watershed perturbations that might have affected water quality, such as wastewater-treatment plant (WWTP) upgrades; examination of residual plots from QWTREND analyses with no trend (null model); temporal distribution of available data; definition of time periods of sufficient length to provide reasonably meaningful information on temporal variability; and changes in analytical methods, such as the change in chlorophyll $a$ methods that occurred in October of 2005.

Multiple QWTREND analyses were run for each site-constituent combination. Identification of trends generally involved a nested comparison of models in which a 1-period trend model was compared with the null (no trend) model, and a 2-period trend model was compared with the corresponding 1-period trend model. The 1-period trend model consisted of a single monotonic (increasing or decreasing) trend for the entire period of record. This period generally was 1989 through 2013, but varied among sites and constituents depending on the availability of data. For sites with sufficient data both before and after the midpoint of the sampling period, the 2-period trend model also was applied. January 1, 2002, was selected as the beginning of the second period in order to divide the 25-year trend period approximately in half and to ensure that each of the smaller periods had at least 10 years of data. The 2-period trend model consisted of two piecewise monotonic trends for "early" and "late" time periods: 1989 (or beginning of record) through 2001, and 2002 through 2013 (or end of record). The generalized likelihood ratio test statistic was used to determine if the 2-period trend model provided a significantly $(\alpha=0.05)$ better fit with the data than the 1-period trend model. The generalized likelihood ratio test is analogous to a partial F-test in a multiple linear regression framework (Helsel and Hirsch, 2002). Only the "best fit" trend model for each site-constituent pairing was selected and presented in the report. For site-constituent combinations with short periods of record, a single trend during either the early or late period may have been the only possibility that could be considered, in which case it was not possible to determine if there was a similar (or different) trend during the missing period.

In two cases, site- or constituent-specific models were examined if known changes in environmental conditions or analytical methods warranted an alternative model. First, a municipal WWTP that discharges to Northeast Creek (site S8) was upgraded to enhance nitrogen removal in July 2005. All constituents at this site were analyzed by using three models: a step trend beginning in July 2005; a 1-period (1989-2013) monotonic trend; and a model that combined the step and 1-period trends. Interestingly, for each constituent evaluated at site S8, either the step trend or the 1-period trend model was selected. The simultaneous step-plus-monotonic trend model did not provide a significantly better fit. 
Second, laboratory methods used to analyze chlorophyll $a$ samples changed radically in October 2005, which warranted including a step function in the trend analyses for this constituent. From 1992 through September 2005, chlorophyll $a$ was analyzed using a high-performance liquid chromatography (HPLC) method that was highly specific for chlorophyll $a$ and no other forms of chlorophyll or accessory pigments. On October 1, 2005, the USGS National Water Quality Laboratory discontinued the HPLC method; thereafter, samples were analyzed using a modified EPA Method 445.0, which collectively measured chlorophyll $a$ and portions of other algal pigments. Evaluation of split-replicate samples conducted prior to the method change indicated that up to threefold increases in reported chlorophyll $a$ concentrations would likely occur. Data collected before and after the method change are not equivalent and should not be combined for trend analysis without including a step function that can accommodate effects of the method change. Therefore, the QWTREND models for chlorophyll $a$ simultaneously evaluated a step function at the method change and a 1-period trend test for the period of record. This approach was critical for distinguishing environmental trends from shifts that resulted from the method change.

The seasonal Kendall (SEAKEN) test (Hirsch and Slack, 1984; Helsel and Hirsch, 2002) is an alternative trend assessment approach often used to evaluate trends in constituent concentrations. A primary advantage of SEAKEN over a parametric time-series approach such as QWTREND is that SEAKEN is a nonparametric procedure and thus requires fewer assumptions than QWTREND. Another advantage of SEAKEN is that it allows up to 50 percent censored values, whereas QWTREND is not recommended for datasets with more than 20 percent censored values.

There are three important advantages of QWTREND compared to SEAKEN. First, QWTREND jointly models flow-related variability and trends using both concurrent and antecedent daily streamflow, whereas SEAKEN is applied to the residuals from a regression model relating concentration and concurrent daily flow (flow-adjusted concentrations). Thus, in many cases QWTREND explains considerably more flow-related variability and makes trends easier to detect compared to SEAKEN. Second, QWTREND can be used to model complex, nonmonotonic trends, whereas SEAKEN assumes a single monotonic trend. Third, QWTREND does not require a fixed sampling interval for concentration, whereas SEAKEN requires a fixed sampling interval (such as monthly sampling). The sampling frequency for QWTREND can vary from month to month, the number of samples can vary from 0 to 3 samples per month, and the timing of the samples within each month is accounted for. SEAKEN requires one sample per interval, with strict limitations on the number and timing of missing values.

\section{Water-Quality Trends Related to Watershed Setting and Hydrologic Conditions}

Water quality is best understood within the context of watershed setting and prevailing hydrologic conditions; therefore, changes in population, land cover, and hydrologic characteristics during the trend period were examined. Statistical summaries of the water-quality properties and constituents selected for trend analysis were useful for identifying site-tosite differences within the study area. Results of water-quality trend analyses are presented for the period 1989-2013 or for shorter periods within that range, depending on the availability and characteristics of the data. The observed trends are discussed in relation to population and land-cover change in the study area as a whole and in relation to site-specific events when warranted.

\section{Population and Land Cover}

The Triangle area experienced rapid development and population growth during the trend period. Population density increased in all of the trend site watersheds on the basis of a comparison of 1990 and 2010 U.S. Census information (table 2; fig. 2). Among watersheds, population density ranged from 59 to 991 people per square mile (people $/ \mathrm{mi}^{2}$ ) in 1990 to 86 to 1,355 people/mi ${ }^{2}$ in 2010. Population increases expressed as percent change from 1990 to 2010 ranged from a minimum of 26 percent for Eno River at Hillsborough (site S1) to 919 percent at White Oak Creek (site S11), with a median increase of 43 percent among all sites. In both 1990 and 2010, population densities were lowest in the watersheds of Little River Reservoir (L1), Lake Michie (L2), and Cane Creek Reservoir (L3) and their major tributaries-Little River (S3), Flat River (S4), and Cane Creek (S5), respectively. The most densely populated watersheds were those draining to the New Hope arm of Jordan Lake (sites L6 and L7), which included New Hope (S7) and Northeast (S8) Creeks near Durham, Morgan Creek near Farrington (S10), and White Oak Creek (S11) west of Cary. In 1990, population density within the White Oak Creek watershed was 133 people $/ \mathrm{mi}^{2}$. By 2010, population in that watershed had increased by an order of magnitude to 1,355 people $/ \mathrm{mi}^{2}$.

Increases in population density were reflected in landcover changes in the watersheds. On the basis of comparisons of 1992 and 2011 land cover, all trend site watersheds experienced increases in developed land and decreases in forested land. Only minor changes were observed for agricultural land (table 3; fig. 3). Circa 1992, 7 of the 13 stream site watersheds were less than 10 percent developed. By 2011, 
Table 2. Population density estimates for trend site watersheds in the Triangle area of North Carolina, 1990 and 2010 , and change from 1990 to 2010.

[mi², square mile; USGS, U.S. Geological Survey. Gray shading represents sites in the Neuse River Basin; unshaded rows represent sites in the Cape Fear River Basin. Site L8 is not included because watershed characteristics were not applicable for site L8; see "Population and Land Cover" for explanation]

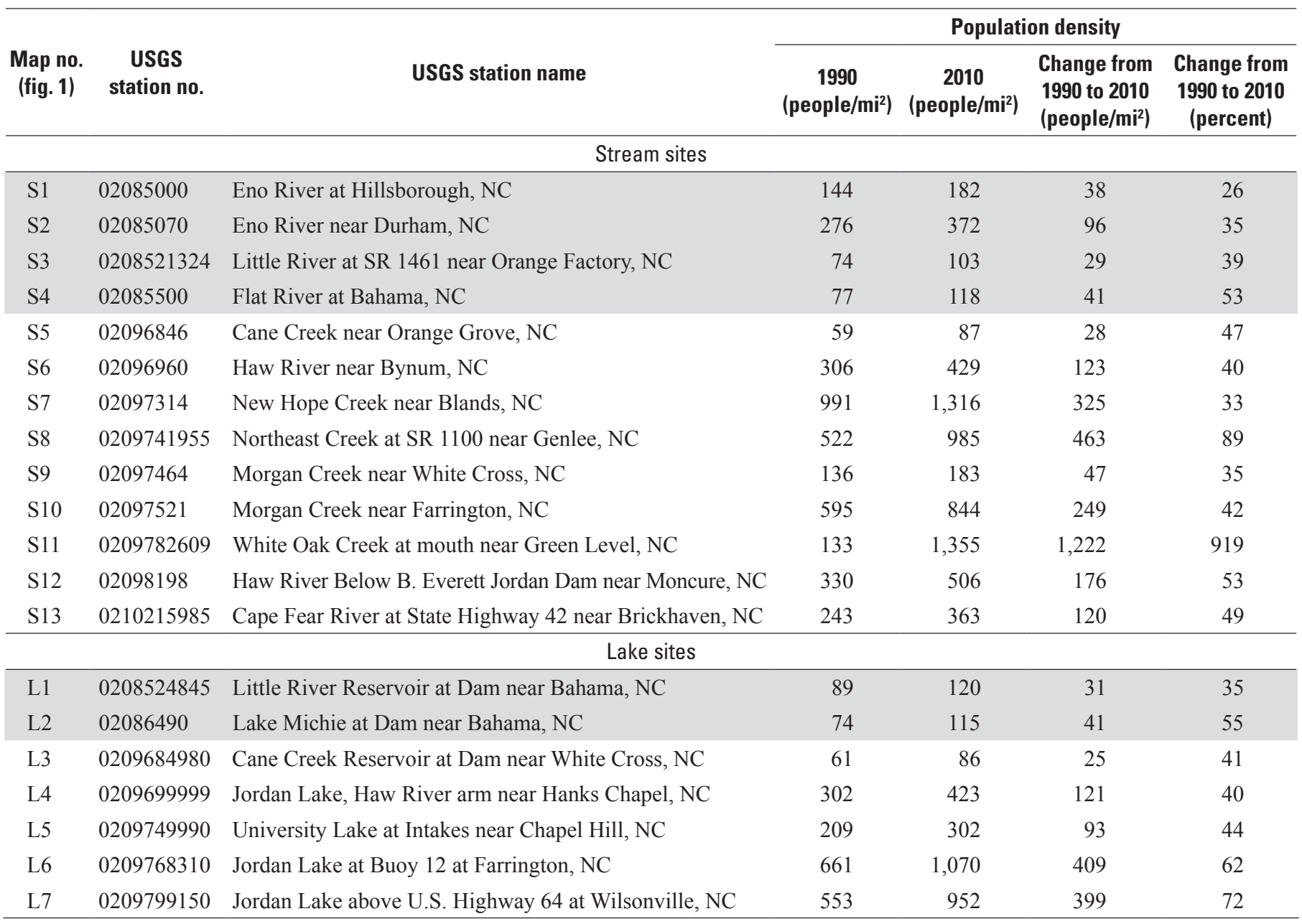

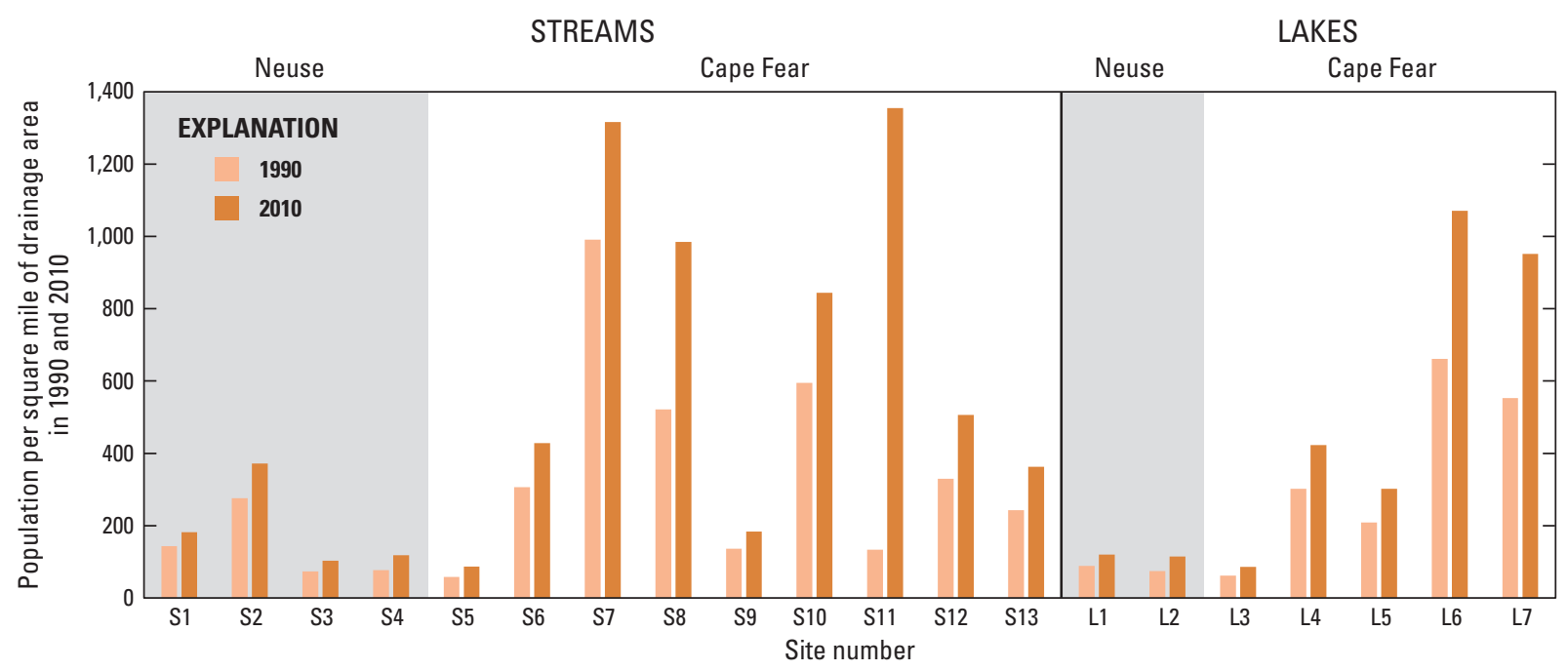

Figure 2. Population density for trend site watersheds in the Triangle area of North Carolina, 1990 and 2010. Site L8 is not included because watershed characteristics were not applicable for site L8; see "Population and Land Cover" for explanation. 
Table 3. Generalized land-cover distribution for trend site watersheds in the Triangle area of North Carolina, circa 1992, circa 2011, and change from 1992 to 2011.

$\left[\mathrm{mi}^{2}\right.$, square mile; USGS, U.S. Geological Survey. Gray shading represents sites in the Neuse River Basin; unshaded rows represent sites in the Cape Fear River Basin. Site L8 is not included because watershed characteristics were not applicable for site L8; see "Population and Land Cover" for explanation]

\begin{tabular}{|c|c|c|c|c|c|c|c|c|c|c|c|c|}
\hline \multirow{3}{*}{$\begin{array}{c}\text { Map } \\
\text { no. } \\
\text { (fig. 1) }\end{array}$} & \multirow{3}{*}{$\begin{array}{c}\text { USGS } \\
\text { station no. }\end{array}$} & \multirow{3}{*}{ USGS station name } & \multirow{3}{*}{$\begin{array}{c}\text { Drain- } \\
\text { age area } \\
\left(\mathrm{mi}^{2}\right)\end{array}$} & \multicolumn{9}{|c|}{ Land-cover distribution, in percent } \\
\hline & & & & \multicolumn{3}{|c|}{ circa $1992^{\mathrm{a}}$} & \multicolumn{3}{|c|}{ circa 2011 b } & \multicolumn{3}{|c|}{ Change from 1992 to 2011} \\
\hline & & & & $\begin{array}{l}\text { Devel- } \\
\text { oped }\end{array}$ & $\begin{array}{l}\text { Agricul- } \\
\text { tural }\end{array}$ & $\begin{array}{l}\text { For- } \\
\text { ested }\end{array}$ & $\begin{array}{l}\text { Devel- } \\
\text { oped }\end{array}$ & $\begin{array}{l}\text { Agricul- } \\
\text { tural }\end{array}$ & $\begin{array}{l}\text { For- } \\
\text { ested }\end{array}$ & $\begin{array}{l}\text { Devel- } \\
\text { oped }\end{array}$ & $\begin{array}{l}\text { Agricul- } \\
\text { tural }\end{array}$ & $\begin{array}{l}\text { For- } \\
\text { ested }\end{array}$ \\
\hline \multicolumn{13}{|c|}{ Stream sites } \\
\hline S1 & 02085000 & Eno River at Hillsborough, NC & 66.0 & 6.4 & 23.3 & 70.3 & 12.5 & 24.3 & 63.2 & 6.1 & 1.0 & -7.1 \\
\hline S2 & 02085070 & Eno River near Durham, NC & 141 & 11.0 & 15.8 & 73.2 & 18.1 & 17.1 & 64.8 & 7.1 & 1.3 & -8.4 \\
\hline S4 & 02085500 & Flat River at Bahama, NC & 149 & 2.5 & 26.8 & 70.7 & 7.1 & 28.0 & 65.0 & 4.5 & 1.2 & -5.7 \\
\hline S5 & 02096846 & Cane Creek near Orange Grove, NC & 7.54 & 0.0 & 15.8 & 84.2 & 4.4 & 17.0 & 78.5 & 4.4 & 1.2 & -5.7 \\
\hline S6 & 02096960 & Haw River near Bynum, NC & 1,275 & 11.4 & 27.6 & 61.0 & 19.7 & 27.6 & 52.7 & 8.2 & -0.0 & -8.2 \\
\hline S7 & 02097314 & New Hope Creek near Blands, NC & 75.9 & 26.8 & 5.3 & 67.9 & 41.6 & 5.3 & 53.1 & 14.8 & -0.0 & -14.8 \\
\hline $\mathrm{S} 10$ & 02097521 & Morgan Creek near Farrington, NC & 46.0 & 11.9 & 9.2 & 78.9 & 20.0 & 10.7 & 69.3 & 8.1 & 1.5 & -9.7 \\
\hline S11 & 0209782609 & $\begin{array}{l}\text { White Oak Creek at mouth near Green } \\
\text { Level, NC }\end{array}$ & 11.9 & 0.7 & 11.6 & 87.6 & 38.7 & 9.3 & 52.0 & 37.9 & -2.3 & -35.6 \\
\hline $\mathrm{S} 12$ & 02098198 & $\begin{array}{l}\text { Haw River below B. Everett Jordan } \\
\text { Dam near Moncure, NC }\end{array}$ & 1,689 & 11.3 & 22.2 & 66.5 & 21.0 & 22.5 & 56.5 & 9.7 & 0.3 & -10.0 \\
\hline $\mathrm{S} 13$ & 0210215985 & $\begin{array}{l}\text { Cape Fear River at State Highway } 42 \\
\text { near Brickhaven, NC }\end{array}$ & 3,160 & 8.5 & 20.0 & 71.6 & 16.8 & 21.7 & 61.5 & 8.3 & 1.8 & -10.1 \\
\hline \multicolumn{13}{|c|}{ Lake sites } \\
\hline L1 & 0208524845 & $\begin{array}{l}\text { Little River Reservoir at Dam near } \\
\text { Bahama, NC }\end{array}$ & 97.7 & 1.7 & 24.5 & 73.8 & 6.9 & 27.1 & 66.0 & 5.2 & 2.6 & -7.8 \\
\hline L6 & 0209768310 & $\begin{array}{l}\text { Jordan Lake at Buoy } 12 \text { at Farrington, } \\
\text { NC }\end{array}$ & 231 & 18.4 & 5.6 & 76.0 & 35.7 & 6.1 & 58.2 & 17.3 & 0.5 & -17.8 \\
\hline L7 & 0209799150 & $\begin{array}{l}\text { Jordan Lake above U.S. Highway } 64 \text { at } \\
\text { Wilsonville, NC }\end{array}$ & 285 & 15.1 & 5.6 & 79.3 & 31.8 & 6.4 & 61.9 & 16.7 & 0.8 & -17.5 \\
\hline
\end{tabular}

a1992 National Land Cover Database (NLCD) classes were aggregated as follows: Developed = classes 21, 22, and 23; Agricultural = classes 81 and 82; Forested $=$ classes 11, 31, 32, 33, 41, 42, 43, and 92. NLCD 1992 class definitions are from Vogelmann and others (2001).

b2011 NLCD classes were aggregated as follows: Developed = classes 21, 22, 23, and 24; Agricultural = classes 81 and 82; Forested = classes 11, 31, 41, 42, 43, 52, 71, 90, and 95. NLCD 2011 class definitions are from Homer and others (2015). 


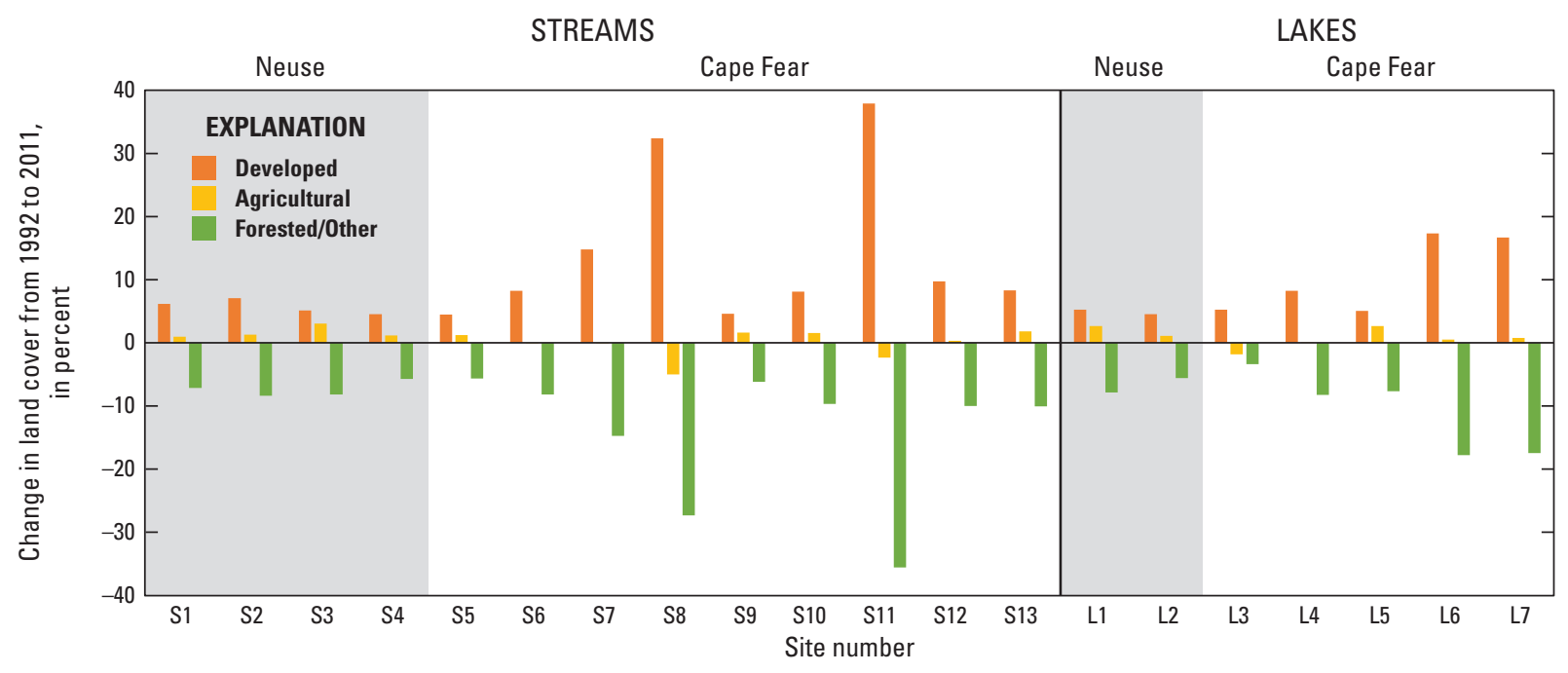

Figure 3. Percent change for generalized land-cover categories for trend site watersheds in the Triangle area of North Carolina from 1992 to 2011. Site L8 is not included because watershed characteristics were not applicable for the site; see "Population and Land Cover" for explanation

only four watersheds remained less than 10 percent developed, including Little River (S3), Flat River (S4), Cane Creek (S5), and Morgan Creek near White Cross (S9) (table 3). Among all study sites, the watershed for White Oak Creek (S11) had the greatest overall land-cover change. Developed lands increased from less than 1 percent to 39 percent of the watershed, and forested lands dropped from 88 to 52 percent. Northeast Creek (S8) watershed experienced a 32-percent increase in developed land cover and a 27-percent decrease in forested/other lands. The lowest amounts of land-cover change were observed in the watersheds of Lake Michie (L2) and Cane Creek Reservoir (L3) as well as their major tributaries Flat River (S4) and Cane Creek (S5), respectively (table 3; fig. 3).

\section{Precipitation and Streamflow}

In a largely unaltered basin, streamflow is strongly influenced by physiographic characteristics and climatic conditions. Likewise, trends in streamflow in such a basin often are associated with similar trends in climatic conditions. When evaluating trends in hydroclimatic records, it is important to consider the potential influence of long-term persistence, which is the natural pattern of wet years tending to follow wet years and dry years tending to follow dry years (Hirsch, 2011). In substantially long hydroclimatic records, multidecadal variations may lead to multiyear periods that exhibit upward and (or) downward fluctuations that are not necessarily indicative of long-term changes in the hydroclimatic system (Lins and Cohn, 2011).

Interpretation of streamflow trends can be complicated further in basins that are influenced by regulation (for example, dams), water withdrawals, and (or) inputs from point sources such as wastewater-treatment facilities. The streamflow in such basins may also be influenced by short-term hydroclimatic conditions, but the anthropogenic influences may mitigate, enhance, or even offset those short-term changes in certain parts of the flow regime. Nonetheless, trend assessments still may prove useful in the broader context of assessing water resources in a basin.

Streamflow sites assessed in this report are located within the Northern Piedmont and Central Piedmont climate divisions (NOAA, 2016). Total annual rainfall for the trend period varied from year to year, and no consistent trend was indicated (fig. 4). In both the Northern and Central Piedmont, 2007 had the lowest annual precipitation, and 2003 had the highest. The study area experienced drought conditions in 2001 and 2007, and precipitation was well below the "climate normal" (that is, the annual average for the period 1981-2010) of 43.34 inches at the Raleigh-Durham International Airport (NOAA, 2017). In addition to the high annual precipitation in 2003, precipitation was well above normal during 1989, 1995, 1996, and 2013.

Many water-quality constituents vary with streamflow; therefore, an assessment of streamflow conditions during the trend period provides a context for understanding waterquality trends. Streamflow is influenced by a wide range of factors that function across multiple time scales. Although the magnitude of change can be assessed with confidence for a given time period, tests of statistical significance for streamflow trends should be interpreted with caution (Cohn and Lins, 2005). Certain watershed features influenced flow patterns observed at the study sites. At some sites, flows from upstream impoundments were regulated; other sites had no upstream flow regulation. Sites ranged from headwater streams with small, undeveloped watersheds to mid- and large-sized rivers that received substantial inflows of treated wastewater and urban runoff and (or) were affected by upstream water-supply withdrawals (table 4). 


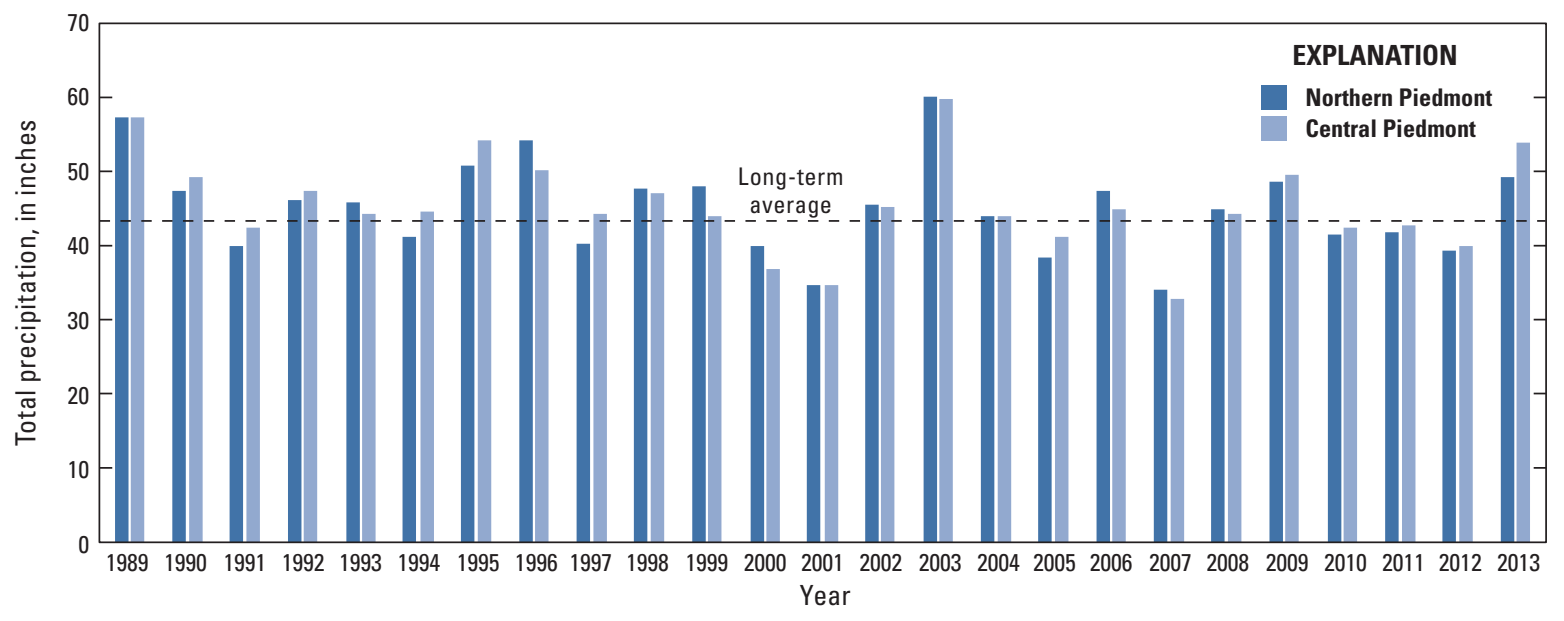

Figure 4. Annual precipitation in the Northern Piedmont and Central Piedmont climate divisions of North Carolina, 1989-2013, and long-term average precipitation at the Raleigh-Durham International Airport, 1981-2010.

Among the four streamflow sites in the Neuse River Basin, no statistically significant trends were indicated for annual minimum 7-day average flows (7Q1) or annual peak flows from 1989 through 2013, with the exception of Eno River at Hillsborough (site S1) where annual peak flows indicated a downward trend. Annual mean flows trended downward at all four sites, including the two Eno River sites (S1 and S2) (table 4). In the late 1980s, concerns regarding competing and unrestricted water-supply withdrawals and decreasing flow in the Eno River led local governments to voluntarily adopt a "Capacity Use Agreement" (North Carolina Department of Natural Resources and Community Development, 1987). At the time, substantial water users included three public water-supply systems and a mining operation. The agreement mandated a minimum instream flow at site S1 and capped withdrawals by each user over a series of stages of water availability.

Of the seven streamflow sites in the Cape Fear River Basin, five indicated downward trends in the 7Q1 flows during the 1989-2013 study period: Cane Creek near Orange Grove (S5), Haw River near Bynum (S6), Morgan Creek near White Cross (S9), Morgan Creek near Chapel Hill (S10Q, which is the source of streamflow data for site S10), and White Oak Creek (S11) (table 4). It should be noted that three of the five sites with downward trends (S5, S9, and S11) had a number of zero flows in the record being analyzed. The Kendall's tau test is based on enumerating concordant (when both the $\mathrm{x}$ and $\mathrm{y}$ variables increase or decrease) and discordant (when $\mathrm{x}$ increases and $\mathrm{y}$ decreases or $\mathrm{x}$ decreases and $\mathrm{y}$ increases) pairs of $\mathrm{x}$ and $\mathrm{y}$ data (Kendall, 1938). Consequently, when stations have a substantial number of zero flows, resulting in numerous pairs of $\mathrm{x}$ and $\mathrm{y}$ data with tied ranks, interpretation of the trend test can become tenuous at best. These three sites also have the smallest drainage areas (7.54 to $11.9 \mathrm{mi}^{2}$ ) and may respond more rapidly to extremes such as droughts. Continued monitoring of streamflow at these sites can provide the data needed to assess trends with greater confidence. New Hope Creek near Blands (S7) indicated no significant trend in 7Q1 flows, and Northeast Creek near Genlee (S8) indicated an upward trend. Both sites S7 and $\mathrm{S} 8$ receive effluent from municipal wastewater-reclamation facilities, and neither site is affected by upstream withdrawals or substantial flow regulation. The additional and consistent input of flow from effluent likely lessened the time periods that these sites experienced low-flow conditions. Annual mean flows trended downward at five sites in the Cape Fear River Basin (S5, S6, S7, S9, and S10Q) during the study period, and no significant trend was noted at the remaining two sites (S8 and S11). No trends were indicated in the annual peak flows at any of the sites.

Durations of daily flow yields for the four Neuse River Basin stations indicated that Flat River (site S4) had a lower yield throughout the full range of flows, although there are no known water diversions upstream from the site (fig. 5). For the other three stations, flow yields were similar at flow durations from one to about the 40th percentile. Under low-flow conditions (highest percentiles), however, yields were relatively higher at the two Eno River sites (S1 and S2) than in the Little River (S3) or Flat River (S4). The higher low-flow yield at site $\mathrm{S} 1$ likely reflected the upstream minimum-release requirements implemented in the late 1980s. The higher low-flow yields at site S2 also reflected the regulated upstream release, as well as anthropogenic inputs from a municipal wastewatertreatment facility.

Flow yields at stations located in the Cape Fear River Basin differed on the basis of contribution of flow from other sources (fig. $6 A$ ). The three stations with small drainage areas and no known withdrawals or point-source inputs (sites S5, S9, and S11) had flow yield curves with a relatively similar shape, although the yield at site S11 substantially dropped for the lowest flows (percentiles greater than 80). Site S11 is located in the Triassic basins, a sedimentary geological formation with low porosity and permeability, where low 


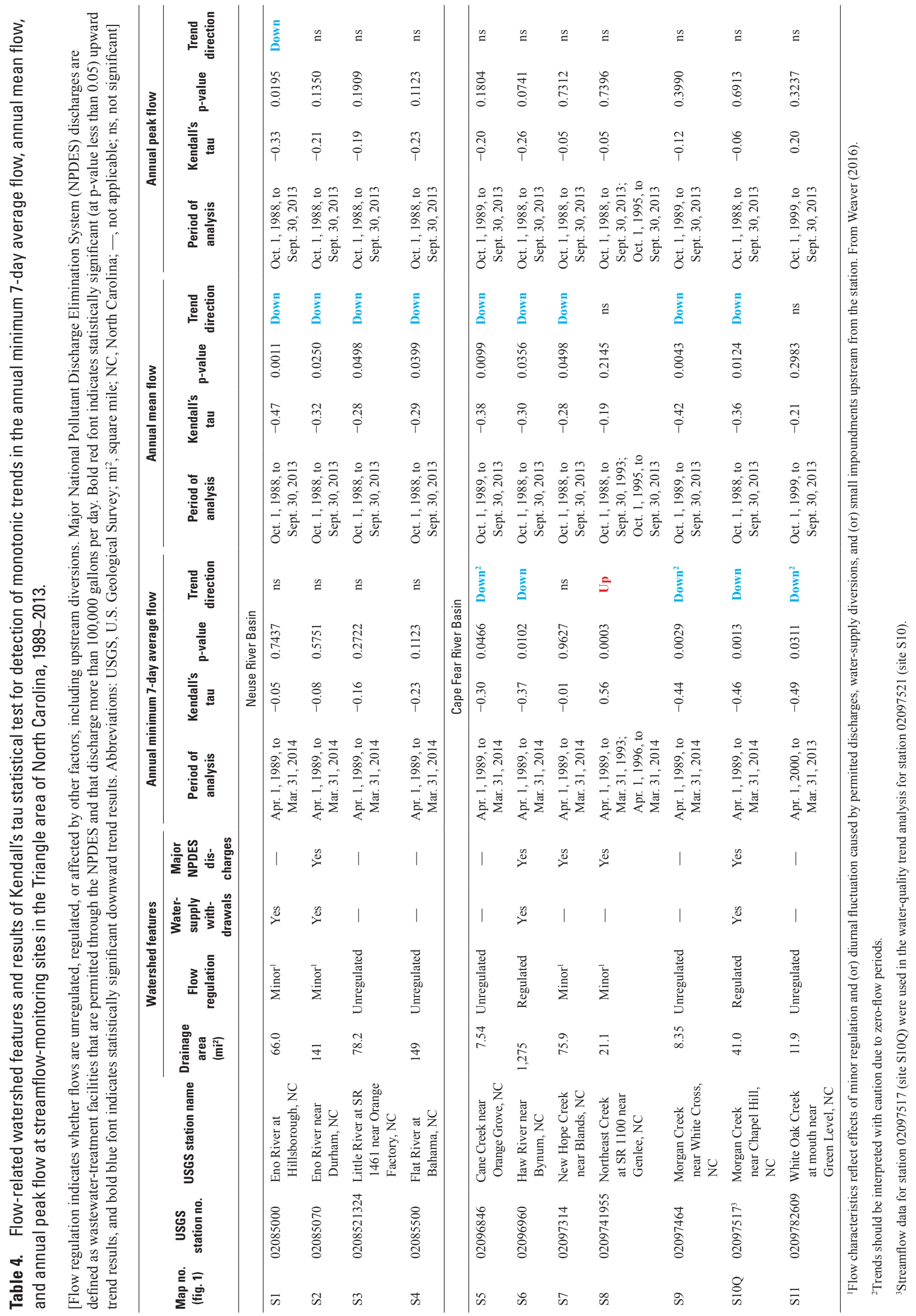




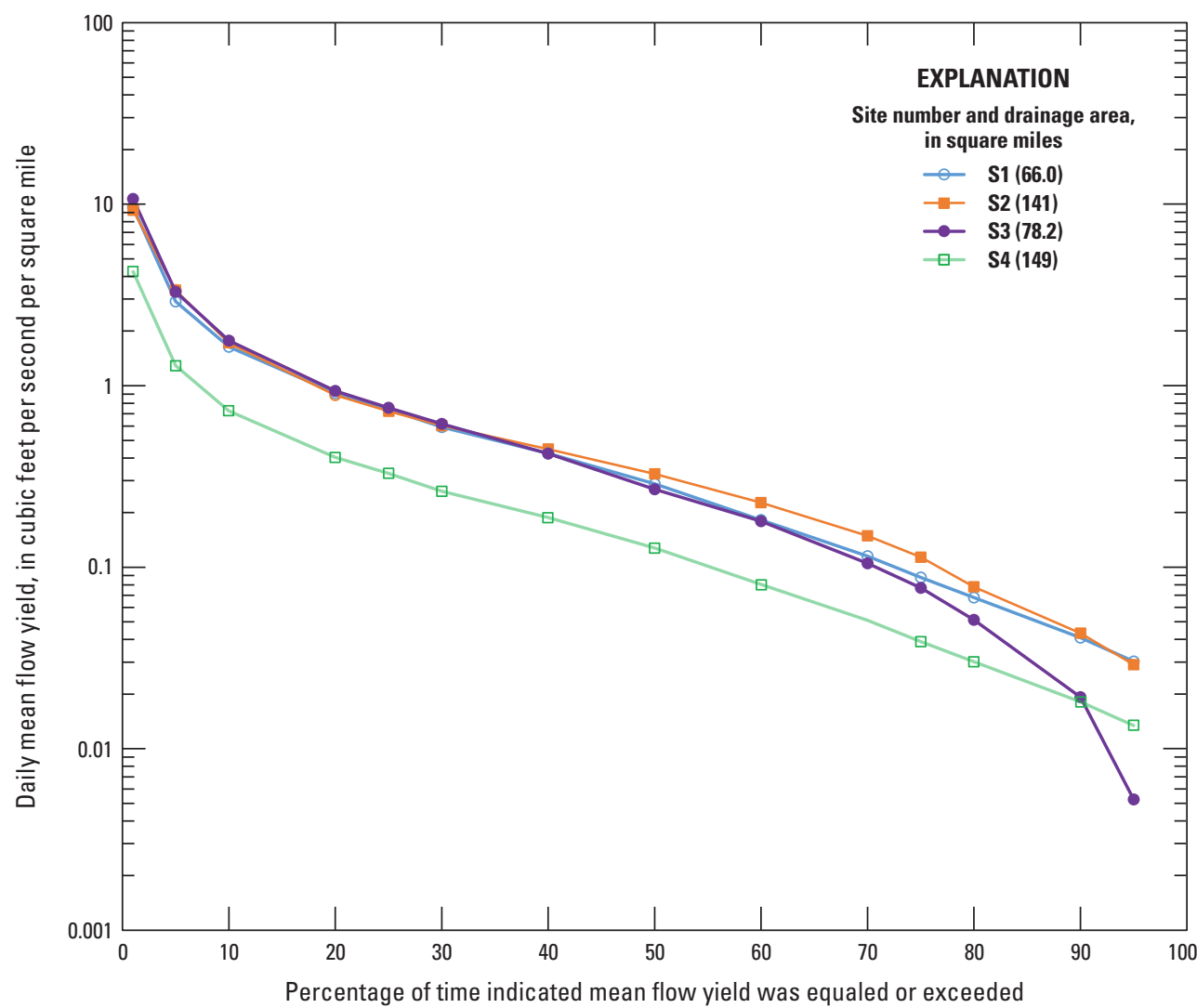

Figure 5. Duration of daily mean flow yields, in cubic feet per second per square mile, for sites S1, S2, S3, and S4 in the Neuse River Basin for the concurrent period October 1, 1988, to September 30, 2013. 


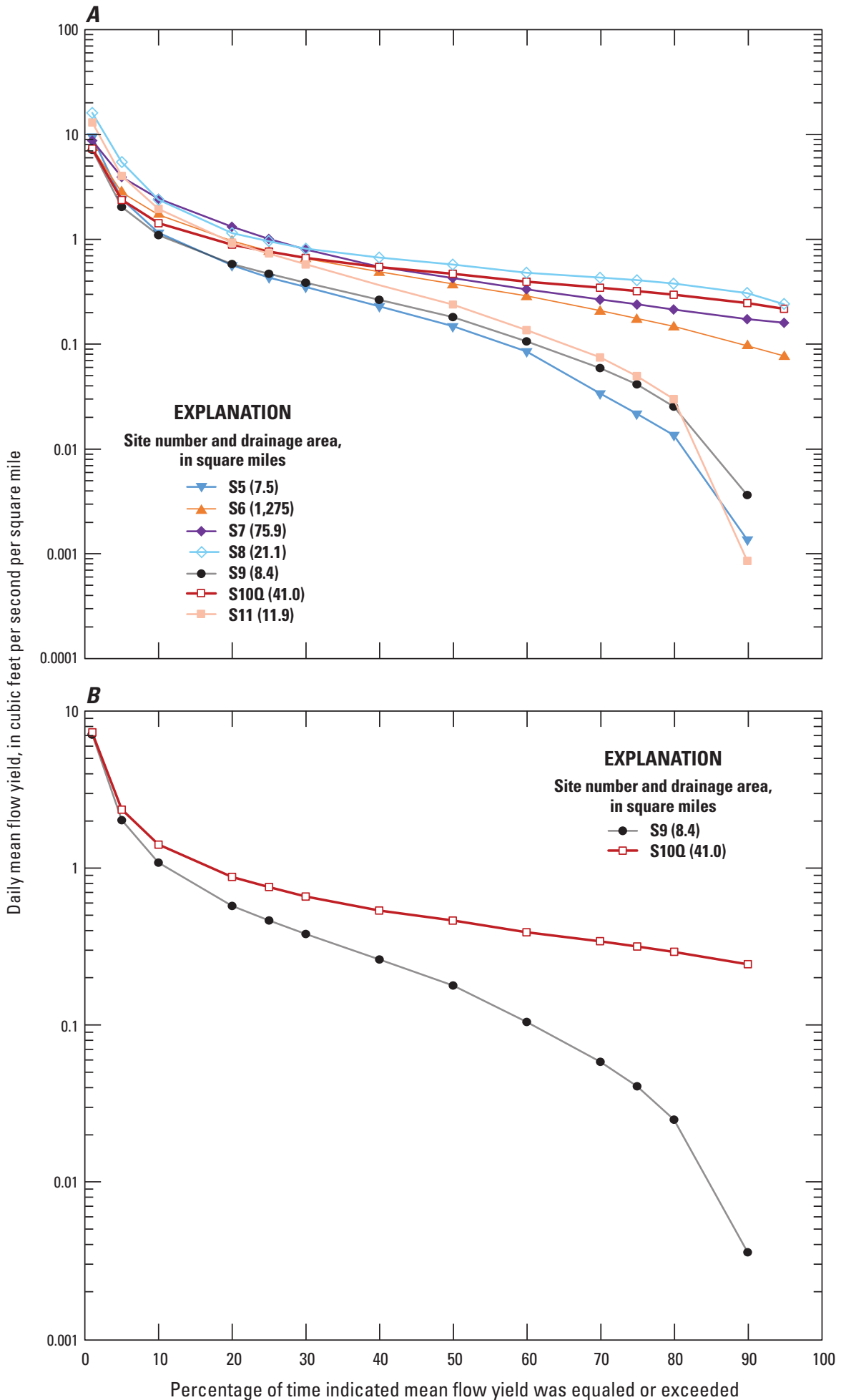

Figure 6. Duration of daily mean flow yields, in cubic feet per second per square mile, for (A) sites S5, S6, S7, S8, S9, S100, and S11 in the Cape Fear River Basin and (B) sites S9 and S100 in Morgan Creek for the concurrent period September 15, 1999, to September 30, 2013. 
yields are typical (Bain and Brown, 1981). The watersheds contributing flow to sites S6 and S10Q have upstream watersupply withdrawals. Sites $\mathrm{S} 6, \mathrm{~S} 7, \mathrm{~S} 8$, and $\mathrm{S} 10 \mathrm{Q}$ receive inputs from major wastewater-treatment facilities, and the influence of anthropogenic discharges to these streams is evident in the higher yields for the lower flows (higher percentiles).

Additional details are evident when durations of daily flow yields are compared for the two Morgan Creek stations for the same period of record (September 15, 1999, to September 30, 2013). Sites S9 and S10Q have very similar yields at higher flows but begin to diverge above the 20th flow percentile. The influence of anthropogenic sources at site S10Q can clearly be seen in the larger yields under low-flow conditions (higher percentiles) (fig. $6 B$ ).

\section{Water Quality}

Trends in concentrations of 17 water-quality properties and constituents were analyzed for selected streams and lakes used for water supply in the Triangle area of North Carolina. Trends are reported in terms of both percent change and magnitude of change in fitted annual-median concentrations from the first year to the last year of the trend period.

\section{Specific Conductance and Major lons}

Specific conductance is a measure of the ability of water to conduct an electrical current at a specified temperature (typically standardized to 25 degrees Celsius). Specific conductance ranges widely in natural waters, depending primarily on underlying geology. In practical terms, specific conductance indicates the overall concentration of charged ions that are present in a water sample; thus, specific conductance generally is closely related to the concentrations of individual ions. Individual ions in this report include the cations calcium, magnesium, potassium, and sodium, and the anions chloride and sulfate. All of these ions occur naturally in water; however, concentrations that are elevated above naturally occurring levels may indicate anthropogenic inputs.

At stream sites in the study area, specific conductance and nutrients were measured by the USGS, NCDEQ, UCFRBA, and MCFRBA; thus, there were substantially more observations for these constituents than for other properties and constituents in the trend datasets (table 5). In contrast, major ions and suspended-sediment data were collected only by the USGS and therefore had fewer observations.

Specific conductance varied considerably among study sites and with streamflow. Concentrations ranged from 21 to $996 \mu \mathrm{S} / \mathrm{cm}$ among stream samples and from 42 to $453 \mu \mathrm{S} / \mathrm{cm}$ among lake samples (table 5). Concentrations at all stream sites tended to be highest during low-flow conditions and lowest when streamflow was high. This likely could be attributed to dilution by incoming stormwater. Streams with the highest median specific conductance were those located in highly developed watersheds and in proximity to National Pollutant Discharge Elimination System (NPDES) discharges (tables 4, 6), including New Hope Creek (site S7), Northeast Creek (site S8), and Morgan Creek near Farrington (site S10). Low specific conductance values were measured at sites with relatively undeveloped watersheds with no NPDES inputs. Among lake sites, the four sites in Jordan Lake had the highest specific conductance (table 7), reflecting the higher concentrations observed in their upstream tributaries. Jordan Lake sites have large drainage areas and diverse anthropogenic inputs, such as treated wastewater and stormwater runoff from developed and (or) agricultural lands.

Trends in specific conductance were analyzed for all 21 sites in the study area (table 8; fig. 7). The time-series model did not produce a trend result for Cane Creek Reservoir (site L3). Of the 20 remaining sites, all but one site (S11) had sufficient data to evaluate both the 1- and 2-period trend models. For White Oak Creek (site S11), only a single trend for the later period (2002-13) could be evaluated.

During 1989-2013, specific conductance significantly increased at 13 sites and significantly decreased at 2 sites. The largest percent increases during the trend period were observed at Northeast Creek (site S8, 63.3 percent) and New Hope Creek (site S7, 43.2 percent). These sites receive municipal wastewater effluent and also have high percentages of developed land. In contrast, specific conductance decreased 25.5 percent at Eno River near Durham (site S2) during 1989-2013 and 7.2 percent at Jordan Lake near Hanks Chapel (site L4) during 1991-2013. Interestingly, major NPDES dischargers are located upstream from these sites. As part of an assessment of water-quality trends in the Nation's rivers, Oelsner and others (2017) reported similar trends in specific conductance during 1992-2002 at several Triangle area sitesspecifically, increasing trends at sites S1, S3, S4, and S7 and a decreasing trend at site $\mathrm{S} 2$.

Specific conductance at Morgan Creek near Farrington (site S10) and Jordan Lake at Buoy 12 (site L6) increased significantly ( 84.5 percent) during the early part of the trend period (1989-2001), but did not change significantly (5.5 percent) during the later part (2002-13). At White Oak Creek (site S11), specific conductance increased significantly during 2002-13.

Sufficient data to assess trends for individual ions were available at 13 sites, including 5 stream and 8 lake sites (table 8). Data for 11 of the 13 sites were sufficient to evaluate both the 1- and 2-period trend models for the entire trend period. Data for White Oak Creek (site S11) were sufficient to evaluate trends for only the late time period (2002-13), and data for Cape Fear River near Brickhaven (site S13) were sufficient to evaluate trends for only the early time period (1989-2001).

As expected, trend patterns for most of the individual ions were similar to those observed for specific conductance. Concentrations of calcium, magnesium, potassium, sodium, and chloride increased significantly at most sites during the various time periods that were analyzed. Overall, trend 
Table 5. Statistical summary of water-quality properties and constituents aggregated for all stream and lake sites in the Triangle area of North Carolina for which trend assessments were conducted.

[Summary statistics for constituents with censored data were determined by use of the Kaplan-Meier technique (Helsel, 2005). Abbreviations: $\mu \mathrm{S} / \mathrm{cm}, \mathrm{micro-}$ siemens per centimeter; ${ }^{\circ} \mathrm{C}$, degree Celsius; $\mathrm{m}$, meter; diss., dissolved; mg/L, milligram per liter; $\mathrm{N}$, nitrogen; $\mathrm{P}$, phosphorus; $\mu \mathrm{g} / \mathrm{L}$, microgram per liter; USGS, U.S. Geological Survey; NCDEQ, North Carolina Department of Environmental Quality; UCFRBA, Upper Cape Fear River Basin Association; MCFRBA, Middle Cape Fear River Basin Association; <, less than]

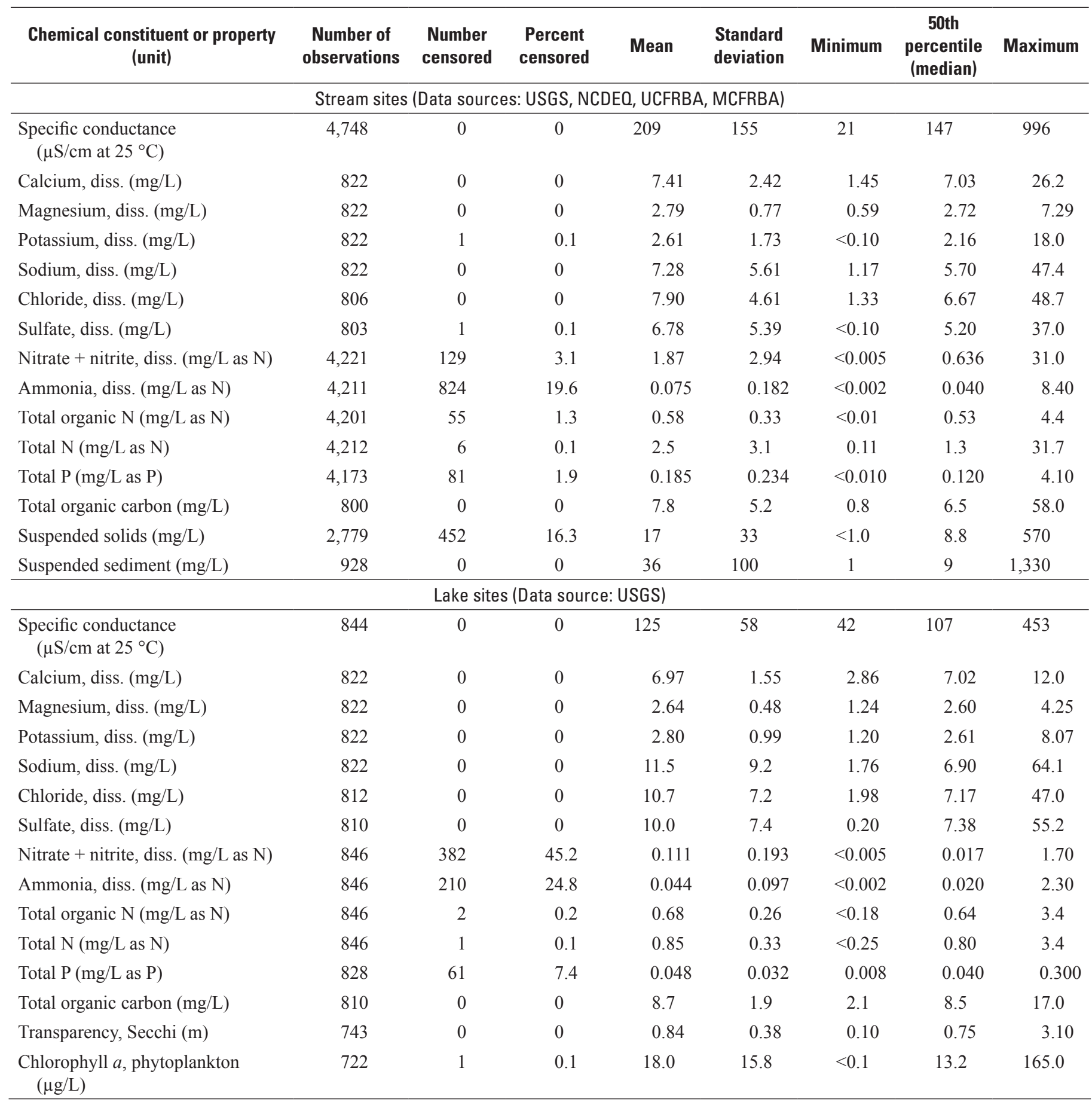


Table 6. Statistical summary of water-quality properties and constituents compiled for trend analysis in the Triangle area of North Carolina, by stream site.

[Summary statistics for constituents with censored data were determined by use of the Kaplan-Meier technique (Helsel, 2005). Gray shading indicates that more than 20 percent of the data for a constituent were censored. Abbreviations: $\mu \mathrm{S} / \mathrm{cm}$, microsiemens per centimeter; ${ }^{\circ} \mathrm{C}$, degree Celsius; diss., dissolved; mg $/ \mathrm{L}$, milligram per liter; $\mathrm{N}$, nitrogen; $\mathrm{P}$, phosphorus; <, less than]

\begin{tabular}{|c|c|c|c|c|c|c|c|c|c|c|c|}
\hline $\begin{array}{l}\text { Map no. } \\
\text { (fig. 1) }\end{array}$ & USGS station name & $\begin{array}{l}\text { Number of } \\
\text { observations }\end{array}$ & $\begin{array}{l}\text { Number } \\
\text { censored }\end{array}$ & $\begin{array}{l}\text { Percent } \\
\text { censored }\end{array}$ & Mean & $\begin{array}{l}\text { Standard } \\
\text { deviation }\end{array}$ & Minimum & $\begin{array}{c}\text { 50th } \\
\text { percentile } \\
\text { (median) }\end{array}$ & Maximum & Start year & End year \\
\hline \multicolumn{12}{|c|}{ Specific conductance $\left(\mu \mathrm{S} / \mathrm{cm}\right.$ at $\left.25^{\circ} \mathrm{C}\right)$} \\
\hline $\mathrm{S} 1$ & Eno River at Hillsborough, NC & 193 & 0 & 0 & 91 & 18 & 33 & 90 & 145 & 1990 & 2013 \\
\hline $\mathrm{S} 2$ & Eno River near Durham, NC & 294 & 0 & 0 & 143 & 83 & 33 & 121 & 615 & 1989 & 2013 \\
\hline $\mathrm{S} 3$ & $\begin{array}{l}\text { Little River at SR } 1461 \text { near Orange } \\
\quad \text { Factory, NC }\end{array}$ & 332 & 0 & 0 & 85 & 26 & 25 & 85 & 315 & 1989 & 2013 \\
\hline $\mathrm{S} 4$ & Flat River at Bahama, NC & 401 & 0 & 0 & 77 & 17 & 24 & 79 & 132 & 1989 & 2011 \\
\hline S5 & Cane Creek near Orange Grove, NC & 223 & 0 & 0 & 86 & 25 & 26 & 82 & 198 & 1989 & 2013 \\
\hline S6 & Haw River near Bynum, NC & 597 & 0 & 0 & 218 & 134 & 33 & 179 & 793 & 1989 & 2013 \\
\hline S7 & New Hope Creek near Blands, NC & 613 & 0 & 0 & 285 & 129 & 37 & 275 & 609 & 1989 & 2013 \\
\hline S8 & $\begin{array}{l}\text { Northeast Creek at SR } 1100 \text { near } \\
\text { Genlee, NC }\end{array}$ & 425 & 0 & 0 & 407 & 184 & 50 & 433 & 996 & 1989 & 2013 \\
\hline S9 & Morgan Creek near White Cross, NC & 201 & 0 & 0 & 109 & 30 & 36 & 108 & 249 & 1989 & 2013 \\
\hline $\mathrm{S} 10$ & Morgan Creek near Farrington, NC & 607 & 0 & 0 & 364 & 152 & 40 & 367 & 750 & 1989 & 2013 \\
\hline $\mathrm{S} 11$ & $\begin{array}{l}\text { White Oak Creek at mouth near Green } \\
\text { Level, NC }\end{array}$ & 93 & 0 & 0 & 94 & 29 & 21 & 92 & 204 & 2000 & 2013 \\
\hline $\mathrm{S} 12$ & $\begin{array}{l}\text { Haw River below B. Everett Jordan } \\
\text { Dam near Moncure, NC }\end{array}$ & 242 & 0 & 0 & 160 & 54 & 45 & 155 & 311 & 1989 & 2013 \\
\hline $\mathrm{S} 13$ & $\begin{array}{l}\text { Cape Fear River at State Highway } 42 \\
\text { near Brickhaven, NC }\end{array}$ & 527 & 0 & 0 & 158 & 53 & 35 & 154 & 359 & 1989 & 2012 \\
\hline \multicolumn{12}{|c|}{ Calcium, diss. (mg/L) } \\
\hline $\mathrm{S} 1$ & Eno River at Hillsborough, NC & 191 & 0 & 0 & 7.05 & 1.58 & 2.90 & 7.00 & 11.3 & 1990 & 2013 \\
\hline S5 & Cane Creek near Orange Grove, NC & 215 & 0 & 0 & 6.99 & 2.34 & 1.94 & 6.70 & 16.4 & 1989 & 2013 \\
\hline S9 & Morgan Creek near White Cross, NC & 195 & 0 & 0 & 9.22 & 3.04 & 2.36 & 8.71 & 26.2 & 1989 & 2013 \\
\hline S11 & $\begin{array}{l}\text { White Oak Creek at mouth near Green } \\
\text { Level, NC }\end{array}$ & 93 & 0 & 0 & 5.92 & 1.63 & 1.45 & 5.92 & 10.5 & 2000 & 2013 \\
\hline $\mathrm{S} 13$ & $\begin{array}{l}\text { Cape Fear River at State Highway } 42 \\
\text { near Brickhaven, NC }\end{array}$ & 128 & 0 & 0 & 6.97 & 1.25 & 2.50 & 6.91 & 10.0 & 1989 & 2003 \\
\hline \multicolumn{12}{|c|}{ Magnesium, diss. (mg/L) } \\
\hline $\mathrm{S} 1$ & Eno River at Hillsborough, NC & 191 & 0 & 0 & 2.84 & 0.54 & 1.10 & 2.87 & 4.05 & 1990 & 2013 \\
\hline S5 & Cane Creek near Orange Grove, NC & 215 & 0 & 0 & 2.61 & 0.80 & 0.80 & 2.50 & 5.65 & 1989 & 2013 \\
\hline S9 & Morgan Creek near White Cross, NC & 195 & 0 & 0 & 3.25 & 0.91 & 1.04 & 3.18 & 7.29 & 1989 & 2013 \\
\hline $\mathrm{S} 11$ & $\begin{array}{l}\text { White Oak Creek at mouth near Green } \\
\text { Level, NC }\end{array}$ & 93 & 0 & 0 & 2.22 & 0.57 & 0.59 & 2.19 & 3.60 & 2000 & 2013 \\
\hline S13 & $\begin{array}{l}\text { Cape Fear River at State Highway } 42 \\
\text { near Brickhaven, NC }\end{array}$ & 128 & 0 & 0 & 2.75 & 0.46 & 1.30 & 2.80 & 4.15 & 1989 & 2003 \\
\hline \multicolumn{12}{|c|}{ Potassium, diss. (mg/L) } \\
\hline $\mathrm{S} 1$ & Eno River at Hillsborough, NC & 191 & 0 & 0 & 1.73 & 0.44 & 0.97 & 1.70 & 3.53 & 1990 & 2013 \\
\hline S5 & Cane Creek near Orange Grove, NC & 215 & 0 & 0 & 2.24 & 1.98 & 0.40 & 1.62 & 15.2 & 1989 & 2013 \\
\hline S9 & Morgan Creek near White Cross, NC & 195 & 1 & 0.5 & 3.17 & 2.30 & $<0.10$ & 2.45 & 18.0 & 1989 & 2013 \\
\hline S11 & $\begin{array}{l}\text { White Oak Creek at mouth near Green } \\
\text { Level, NC }\end{array}$ & 93 & 0 & 0 & 3.05 & 0.77 & 1.93 & 2.94 & 6.28 & 2000 & 2013 \\
\hline $\mathrm{S} 13$ & $\begin{array}{l}\text { Cape Fear River at State Highway } 42 \\
\text { near Brickhaven, NC }\end{array}$ & 128 & 0 & 0 & 3.42 & 1.11 & 1.50 & 3.31 & 7.72 & 1989 & 2003 \\
\hline
\end{tabular}


Table 6. Statistical summary of water-quality properties and constituents compiled for trend analysis in the Triangle area of North Carolina, by stream site.-Continued

[Summary statistics for constituents with censored data were determined by use of the Kaplan-Meier technique (Helsel, 2005). Gray shading indicates that more than 20 percent of the data for a constituent were censored. Abbreviations: $\mu \mathrm{S} / \mathrm{cm}$, microsiemens per centimeter; ${ }^{\circ} \mathrm{C}$, degree Celsius; diss., dissolved; mg/L, milligram per liter; $\mathrm{N}$, nitrogen; $\mathrm{P}$, phosphorus; <, less than]

\begin{tabular}{|c|c|c|c|c|c|c|c|c|c|c|c|}
\hline $\begin{array}{l}\text { Map no. } \\
\text { (fig. 1) }\end{array}$ & USGS station name & $\begin{array}{c}\text { Number of } \\
\text { observations }\end{array}$ & $\begin{array}{l}\text { Number } \\
\text { censored }\end{array}$ & $\begin{array}{l}\text { Percent } \\
\text { censored }\end{array}$ & Mean & $\begin{array}{l}\text { Standard } \\
\text { deviation }\end{array}$ & Minimum & $\begin{array}{c}\text { 50th } \\
\text { percentile } \\
\text { (median) }\end{array}$ & Maximum & Start year & End year \\
\hline \multicolumn{12}{|c|}{ Sodium, diss. (mg/L) } \\
\hline $\mathrm{S} 1$ & Eno River at Hillsborough, NC & 191 & 0 & 0 & 5.50 & 1.48 & 1.40 & 5.50 & 16.0 & 1990 & 2013 \\
\hline S5 & Cane Creek near Orange Grove, NC & 215 & 0 & 0 & 4.86 & 1.08 & 1.17 & 5.02 & 8.56 & 1989 & 2013 \\
\hline S9 & Morgan Creek near White Cross, NC & 195 & 0 & 0 & 5.48 & 1.23 & 1.41 & 5.50 & 9.84 & 1989 & 2013 \\
\hline $\mathrm{S} 11$ & $\begin{array}{l}\text { White Oak Creek at mouth near Green } \\
\text { Level, NC }\end{array}$ & 93 & 0 & 0 & 7.45 & 3.35 & 1.68 & 6.88 & 25.6 & 2000 & 2013 \\
\hline $\mathrm{S} 13$ & $\begin{array}{l}\text { Cape Fear River at State Highway } 42 \\
\text { near Brickhaven, NC }\end{array}$ & 128 & 0 & 0 & 16.6 & 9.0 & 2.70 & 14.0 & 47.4 & 1989 & 2003 \\
\hline \multicolumn{12}{|c|}{ Chloride, diss. (mg/L) } \\
\hline $\mathrm{S} 1$ & Eno River at Hillsborough, NC & 187 & 0 & 0 & 6.00 & 1.94 & 1.60 & 5.57 & 15.0 & 1990 & 2013 \\
\hline S5 & Cane Creek near Orange Grove, NC & 209 & 0 & 0 & 6.18 & 1.82 & 1.33 & 6.00 & 19.1 & 1989 & 2013 \\
\hline S9 & Morgan Creek near White Cross, NC & 194 & 0 & 0 & 7.06 & 1.89 & 2.81 & 6.70 & 17.0 & 1989 & 2013 \\
\hline $\mathrm{S} 11$ & $\begin{array}{l}\text { White Oak Creek at mouth near Green } \\
\text { Level, NC }\end{array}$ & 93 & 0 & 0 & 8.93 & 5.41 & 1.60 & 7.98 & 48.7 & 2000 & 2013 \\
\hline S13 & $\begin{array}{l}\text { Cape Fear River at State Highway } 42 \\
\text { near Brickhaven, NC }\end{array}$ & 123 & 0 & 0 & 14.2 & 6.9 & 4.80 & 12.0 & 39.3 & 1989 & 2003 \\
\hline \multicolumn{12}{|c|}{ Sulfate, diss. (mg/L) } \\
\hline S1 & Eno River at Hillsborough, NC & 186 & 0 & 0 & 5.56 & 1.74 & 2.40 & 5.30 & 14.0 & 1990 & 2013 \\
\hline S5 & Cane Creek near Orange Grove, NC & 208 & 0 & 0 & 3.93 & 1.83 & 0.43 & 3.70 & 14.7 & 1989 & 2013 \\
\hline S9 & Morgan Creek near White Cross, NC & 193 & 1 & 0.5 & 4.81 & 2.45 & $<0.10$ & 4.30 & 22.0 & 1989 & 2013 \\
\hline $\mathrm{S} 11$ & $\begin{array}{l}\text { White Oak Creek at mouth near Green } \\
\text { Level, NC }\end{array}$ & 93 & 0 & 0 & 7.60 & 4.72 & 1.37 & 6.98 & 32.0 & 2000 & 2013 \\
\hline $\mathrm{S} 13$ & $\begin{array}{l}\text { Cape Fear River at State Highway } 42 \\
\text { near Brickhaven, NC }\end{array}$ & 123 & 0 & 0 & 15.9 & 6.9 & 4.00 & 14.0 & 37.0 & 1989 & 2003 \\
\hline \multicolumn{12}{|c|}{ Nitrate + nitrite, diss. (mg/L as N) } \\
\hline $\mathrm{S} 1$ & Eno River at Hillsborough, $\mathrm{NC}$ & 192 & 0 & 0.0 & 0.264 & 0.111 & 0.036 & 0.270 & 0.600 & 1990 & 2013 \\
\hline S2 & Eno River near Durham, NC & 251 & 12 & 4.8 & 0.317 & 0.230 & $<0.01$ & 0.300 & 1.60 & 1989 & 2013 \\
\hline S3 & $\begin{array}{l}\text { Little River at SR } 1461 \text { near Orange } \\
\text { Factory, NC }\end{array}$ & 295 & 29 & 9.8 & 0.260 & 0.191 & $<0.01$ & 0.250 & 1.32 & 1989 & 2013 \\
\hline S4 & Flat River at Bahama, NC & 309 & 28 & 9.1 & 0.243 & 0.162 & $<0.008$ & 0.240 & 0.800 & 1989 & 2011 \\
\hline S5 & Cane Creek near Orange Grove, NC & 217 & 8 & 3.7 & 0.536 & 0.395 & $<0.005$ & 0.530 & 4.16 & 1989 & 2013 \\
\hline S6 & Haw River near Bynum, NC & 582 & 1 & 0.2 & 1.08 & 0.718 & $<0.02$ & 0.870 & 4.40 & 1989 & 2013 \\
\hline S7 & New Hope Creek near Blands, NC & 545 & 1 & 0.2 & 3.74 & 3.13 & $<0.02$ & 3.00 & 31.0 & 1989 & 2013 \\
\hline S8 & $\begin{array}{l}\text { Northeast Creek at SR } 1100 \text { near } \\
\text { Genlee, NC }\end{array}$ & 421 & 3 & 0.7 & 4.42 & 5.19 & $<0.01$ & 2.30 & 29.0 & 1989 & 2013 \\
\hline S9 & Morgan Creek near White Cross, NC & 199 & 9 & 4.5 & 0.556 & 0.361 & $<0.005$ & 0.540 & 1.70 & 1989 & 2013 \\
\hline $\mathrm{S} 10$ & Morgan Creek near Farrington, NC & 549 & 3 & 0.5 & 4.67 & 3.10 & $<0.01$ & 4.00 & 18.2 & 1989 & 2013 \\
\hline S11 & $\begin{array}{l}\text { White Oak Creek at mouth near Green } \\
\text { Level, NC }\end{array}$ & 93 & 9 & 9.7 & 0.055 & 0.064 & $<0.005$ & 0.035 & 0.430 & 2000 & 2013 \\
\hline $\mathrm{S} 12$ & $\begin{array}{l}\text { Haw River below B. Everett Jordan } \\
\text { Dam near Moncure, NC }\end{array}$ & 134 & 1 & 0.7 & 0.507 & 0.265 & $<0.01$ & 0.480 & 1.30 & 1989 & 2000 \\
\hline $\mathrm{S} 13$ & $\begin{array}{l}\text { Cape Fear River at State Highway } 42 \\
\text { near Brickhaven, NC }\end{array}$ & 434 & 25 & 5.8 & 0.510 & 0.287 & 0.007 & 0.520 & 1.79 & 1989 & 2012 \\
\hline
\end{tabular}


Table 6. Statistical summary of water-quality properties and constituents compiled for trend analysis in the Triangle area of North Carolina, by stream site.-Continued

[Summary statistics for constituents with censored data were determined by use of the Kaplan-Meier technique (Helsel, 2005). Gray shading indicates that more than 20 percent of the data for a constituent were censored. Abbreviations: $\mu \mathrm{S} / \mathrm{cm}$, microsiemens per centimeter; ${ }^{\circ} \mathrm{C}$, degree Celsius; diss., dissolved; $\mathrm{mg} / \mathrm{L}$, milligram per liter; N, nitrogen; $\mathrm{P}$, phosphorus; <, less than]

\begin{tabular}{|c|c|c|c|c|c|c|c|c|c|c|c|}
\hline $\begin{array}{l}\text { Map no. } \\
\text { (fig. 1) }\end{array}$ & USGS station name & $\begin{array}{l}\text { Number of } \\
\text { observations }\end{array}$ & $\begin{array}{l}\text { Number } \\
\text { censored }\end{array}$ & $\begin{array}{l}\text { Percent } \\
\text { censored }\end{array}$ & Mean & $\begin{array}{l}\text { Standard } \\
\text { deviation }\end{array}$ & Minimum & $\begin{array}{c}\text { 50th } \\
\text { percentile } \\
\text { (median) }\end{array}$ & Maximum & Start year & End year \\
\hline \multicolumn{12}{|c|}{ Ammonia, diss. (mg/L as N) } \\
\hline S1 & Eno River at Hillsborough, NC & 192 & 20 & 10.4 & 0.042 & 0.077 & $<0.002$ & 0.030 & 1.02 & 1990 & 2013 \\
\hline $\mathrm{S} 2$ & Eno River near Durham, NC & 251 & 75 & 29.9 & 0.041 & 0.048 & $<0.01$ & 0.030 & 0.460 & 1989 & 2013 \\
\hline S3 & $\begin{array}{l}\text { Little River at SR } 1461 \text { near Orange } \\
\text { Factory, NC }\end{array}$ & 295 & 136 & 46.1 & 0.027 & 0.045 & 0.005 & 0.012 & 0.460 & 1989 & 2013 \\
\hline S4 & Flat River at Bahama, NC & 309 & 95 & 30.7 & 0.039 & 0.040 & $<0.002$ & 0.028 & 0.320 & 1989 & 2011 \\
\hline S5 & Cane Creek near Orange Grove, NC & 217 & 57 & 26.3 & 0.034 & 0.049 & $<0.002$ & 0.018 & 0.360 & 1989 & 2013 \\
\hline S6 & Haw River near Bynum, NC & 578 & 177 & 30.6 & 0.052 & 0.075 & 0.005 & 0.030 & 0.820 & 1989 & 2013 \\
\hline S7 & New Hope Creek near Blands, NC & 543 & 56 & 10.3 & 0.085 & 0.158 & 0.009 & 0.050 & 2.30 & 1989 & 2013 \\
\hline S8 & $\begin{array}{l}\text { Northeast Creek at SR } 1100 \text { near } \\
\text { Genlee, NC }\end{array}$ & 421 & 36 & 8.6 & 0.150 & 0.470 & $<0.01$ & 0.050 & 8.40 & 1989 & 2013 \\
\hline S9 & Morgan Creek near White Cross, NC & 199 & 38 & 19.1 & 0.058 & 0.142 & $<0.002$ & 0.020 & 1.50 & 1989 & 2013 \\
\hline $\mathrm{S} 10$ & Morgan Creek near Farrington, NC & 546 & 40 & 7.3 & 0.128 & 0.143 & $<0.01$ & 0.080 & 1.20 & 1989 & 2013 \\
\hline S11 & $\begin{array}{l}\text { White Oak Creek at mouth near Green } \\
\text { Level, NC }\end{array}$ & 93 & 16 & 17.2 & 0.025 & 0.020 & 0.002 & 0.018 & 0.104 & 2000 & 2013 \\
\hline $\mathrm{S} 12$ & $\begin{array}{l}\text { Haw River below B. Everett Jordan } \\
\text { Dam near Moncure, NC }\end{array}$ & 133 & 2 & 1.5 & 0.147 & 0.137 & $<0.01$ & 0.110 & 0.700 & 1989 & 2000 \\
\hline S13 & $\begin{array}{l}\text { Cape Fear River at State Highway } 42 \\
\text { near Brickhaven, NC }\end{array}$ & 434 & 76 & 17.5 & 0.070 & 0.068 & 0.002 & 0.060 & 0.580 & 1989 & 2012 \\
\hline \multicolumn{12}{|c|}{ Total organic N (mg/L as N) } \\
\hline $\mathrm{S} 1$ & Eno River at Hillsborough, NC & 186 & 3 & 1.6 & 0.39 & 0.26 & 0.13 & 0.33 & 2.8 & 1990 & 2013 \\
\hline $\mathrm{S} 2$ & Eno River near Durham, NC & 250 & 1 & 0.4 & 0.33 & 0.16 & 0.01 & 0.32 & 1.6 & 1989 & 2013 \\
\hline S3 & $\begin{array}{l}\text { Little River at SR } 1461 \text { near Orange } \\
\text { Factory, NC }\end{array}$ & 294 & 2 & 0.7 & 0.39 & 0.28 & 0.05 & 0.32 & 2.0 & 1989 & 2013 \\
\hline S4 & Flat River at Bahama, NC & 309 & 4 & 1.3 & 0.38 & 0.27 & $<0.01$ & 0.29 & 2.0 & 1989 & 2011 \\
\hline S5 & Cane Creek near Orange Grove, NC & 216 & 11 & 5.1 & 0.57 & 0.62 & $<0.08$ & 0.35 & 4.4 & 1989 & 2013 \\
\hline S6 & Haw River near Bynum, NC & 578 & 5 & 0.9 & 0.58 & 0.23 & $<0.01$ & 0.56 & 2.0 & 1989 & 2013 \\
\hline S7 & New Hope Creek near Blands, NC & 542 & 6 & 1.1 & 0.76 & 0.27 & $<0.07$ & 0.77 & 2.6 & 1989 & 2013 \\
\hline S8 & $\begin{array}{l}\text { Northeast Creek at SR } 1100 \text { near } \\
\text { Genlee, NC }\end{array}$ & 421 & 2 & 0.5 & 0.82 & 0.31 & 0.06 & 0.81 & 3.1 & 1989 & 2013 \\
\hline S9 & Morgan Creek near White Cross, NC & 199 & 7 & 3.5 & 0.47 & 0.40 & 0.11 & 0.37 & 3.1 & 1989 & 2013 \\
\hline $\mathrm{S} 10$ & Morgan Creek near Farrington, NC & 546 & 11 & 2.0 & 0.66 & 0.25 & 0.01 & 0.69 & 1.9 & 1989 & 2013 \\
\hline S11 & $\begin{array}{l}\text { White Oak Creek at mouth near Green } \\
\text { Level, NC }\end{array}$ & 93 & 0 & 0.0 & 0.59 & 0.17 & 0.32 & 0.57 & 1.2 & 2000 & 2013 \\
\hline $\mathrm{S} 12$ & $\begin{array}{l}\text { Haw River below B. Everett Jordan } \\
\text { Dam near Moncure, NC }\end{array}$ & 133 & 0 & 0.0 & 0.42 & 0.17 & 0.10 & 0.39 & 1.2 & 1989 & 2000 \\
\hline $\mathrm{S} 13$ & $\begin{array}{l}\text { Cape Fear River at State Highway } 42 \\
\text { near Brickhaven, NC }\end{array}$ & 434 & 3 & 0.7 & 0.64 & 0.26 & 0.01 & 0.61 & 2.3 & 1989 & 2012 \\
\hline
\end{tabular}


Table 6. Statistical summary of water-quality properties and constituents compiled for trend analysis in the Triangle area of North Carolina, by stream site.-Continued

[Summary statistics for constituents with censored data were determined by use of the Kaplan-Meier technique (Helsel, 2005). Gray shading indicates that more than 20 percent of the data for a constituent were censored. Abbreviations: $\mu \mathrm{S} / \mathrm{cm}$, microsiemens per centimeter; ${ }^{\circ} \mathrm{C}$, degree Celsius; diss., dissolved; mg/L, milligram per liter; $\mathrm{N}$, nitrogen; $\mathrm{P}$, phosphorus; <, less than]

\begin{tabular}{|c|c|c|c|c|c|c|c|c|c|c|c|}
\hline $\begin{array}{l}\text { Map no. } \\
\text { (fig. 1) }\end{array}$ & USGS station name & $\begin{array}{c}\text { Number of } \\
\text { observations }\end{array}$ & $\begin{array}{l}\text { Number } \\
\text { censored }\end{array}$ & $\begin{array}{l}\text { Percent } \\
\text { censored }\end{array}$ & Mean & $\begin{array}{l}\text { Standard } \\
\text { deviation }\end{array}$ & Minimum & $\begin{array}{c}\text { 50th } \\
\text { percentile } \\
\text { (median) }\end{array}$ & Maximum & Start year & End year \\
\hline \multicolumn{12}{|c|}{ Total N (mg/L as N) } \\
\hline $\mathrm{S} 1$ & Eno River at Hillsborough, NC & 186 & 0 & 0 & 0.70 & 0.32 & 0.26 & 0.63 & 3.4 & 1990 & 2013 \\
\hline S2 & Eno River near Durham, NC & 251 & 0 & 0 & 0.69 & 0.28 & 0.23 & 0.63 & 1.8 & 1989 & 2013 \\
\hline $\mathrm{S} 3$ & $\begin{array}{l}\text { Little River at SR } 1461 \text { near Orange } \\
\text { Factory, NC }\end{array}$ & 295 & 1 & 0.3 & 0.68 & 0.36 & 0.13 & 0.62 & 2.5 & 1989 & 2013 \\
\hline S4 & Flat River at Bahama, $\mathrm{NC}$ & 309 & 3 & 1.0 & 0.66 & 0.34 & 0.11 & 0.60 & 2.5 & 1989 & 2011 \\
\hline S5 & Cane Creek near Orange Grove, NC & 217 & 0 & 0 & 1.1 & 0.8 & 0.24 & 0.93 & 5.5 & 1989 & 2013 \\
\hline S6 & Haw River near Bynum, NC & 582 & 0 & 0 & 1.7 & 0.8 & 0.51 & 1.5 & 5.3 & 1989 & 2013 \\
\hline S7 & New Hope Creek near Blands, NC & 545 & 0 & 0 & 4.6 & 3.2 & 0.53 & 3.8 & 31.7 & 1989 & 2013 \\
\hline S8 & $\begin{array}{l}\text { Northeast Creek at SR } 1100 \text { near } \\
\text { Genlee, NC }\end{array}$ & 421 & 0 & 0 & 5.4 & 5.3 & 0.34 & 3.3 & 29.2 & 1989 & 2013 \\
\hline S9 & Morgan Creek near White Cross, NC & 199 & 0 & 0 & 1.1 & 0.6 & 0.19 & 0.96 & 4.4 & 1989 & 2013 \\
\hline $\mathrm{S} 10$ & Morgan Creek near Farrington, NC & 547 & 0 & 0 & 5.5 & 3.2 & 0.39 & 4.8 & 18.6 & 1989 & 2013 \\
\hline $\mathrm{S} 11$ & $\begin{array}{l}\text { White Oak Creek at mouth near Green } \\
\text { Level, NC }\end{array}$ & 93 & 0 & 0 & 0.67 & 0.21 & 0.39 & 0.63 & 1.4 & 2000 & 2013 \\
\hline $\mathrm{S} 12$ & $\begin{array}{l}\text { Haw River below B. Everett Jordan } \\
\text { Dam near Moncure, NC }\end{array}$ & 133 & 0 & 0 & 1.1 & 0.3 & 0.45 & 1.0 & 2.0 & 1989 & 2000 \\
\hline $\mathrm{S} 13$ & $\begin{array}{l}\text { Cape Fear River at State Highway } 42 \\
\text { near Brickhaven, NC }\end{array}$ & 434 & 2 & 0.5 & 1.2 & 0.4 & $<0.13$ & 1.2 & 3.2 & 1989 & 2012 \\
\hline \multicolumn{12}{|c|}{ Total P (mg/L as P) } \\
\hline S1 & Eno River at Hillsborough, NC & 182 & 17 & 9.3 & 0.044 & 0.045 & $<0.010$ & 0.030 & 0.330 & 1990 & 2013 \\
\hline $\mathrm{S} 2$ & Eno River near Durham, NC & 252 & 4 & 1.6 & 0.055 & 0.049 & $<0.010$ & 0.040 & 0.458 & 1989 & 2013 \\
\hline S3 & $\begin{array}{l}\text { Little River at SR } 1461 \text { near Orange } \\
\text { Factory, NC }\end{array}$ & 293 & 10 & 3.4 & 0.062 & 0.079 & $<0.010$ & 0.040 & 0.646 & 1989 & 2013 \\
\hline S4 & Flat River at Bahama, $\mathrm{NC}$ & 309 & 22 & 7.1 & 0.062 & 0.065 & $<0.010$ & 0.040 & 0.490 & 1989 & 2011 \\
\hline S5 & Cane Creek near Orange Grove, NC & 214 & 11 & 5.1 & 0.123 & 0.191 & $<0.010$ & 0.050 & 0.997 & 1989 & 2013 \\
\hline S6 & Haw River near Bynum, NC & 563 & 2 & 0.4 & 0.167 & 0.106 & $<0.020$ & 0.140 & 0.820 & 1989 & 2013 \\
\hline S7 & New Hope Creek near Blands, NC & 545 & 1 & 0.2 & 0.354 & 0.353 & $<0.010$ & 0.240 & 4.10 & 1989 & 2013 \\
\hline $\mathrm{S} 8$ & $\begin{array}{l}\text { Northeast Creek at SR } 1100 \text { near } \\
\text { Genlee, NC }\end{array}$ & 420 & 0 & 0 & 0.392 & 0.341 & 0.040 & 0.280 & 1.82 & 1989 & 2013 \\
\hline S9 & Morgan Creek near White Cross, NC & 198 & 1 & 0.5 & 0.181 & 0.258 & 0.013 & 0.107 & 2.80 & 1989 & 2013 \\
\hline $\mathrm{S} 10$ & Morgan Creek near Farrington, NC & 548 & 2 & 0.4 & 0.216 & 0.193 & $<0.010$ & 0.160 & 1.60 & 1989 & 2013 \\
\hline $\mathrm{S} 11$ & $\begin{array}{l}\text { White Oak Creek at mouth near Green } \\
\text { Level, NC }\end{array}$ & 89 & 9 & 10.1 & 0.065 & 0.045 & 0.026 & 0.051 & 0.294 & 2000 & 2013 \\
\hline $\mathrm{S} 12$ & $\begin{array}{l}\text { Haw River below B. Everett Jordan } \\
\text { Dam near Moncure, NC }\end{array}$ & 134 & 0 & 0 & 0.109 & 0.047 & 0.030 & 0.100 & 0.270 & 1989 & 2000 \\
\hline $\mathrm{S} 13$ & $\begin{array}{l}\text { Cape Fear River at State Highway } 42 \\
\text { near Brickhaven, NC }\end{array}$ & 426 & 2 & 0.5 & 0.138 & 0.106 & $<0.010$ & 0.120 & 1.40 & 1989 & 2012 \\
\hline \multicolumn{12}{|c|}{ Total organic carbon (mg/L) } \\
\hline $\mathrm{S} 1$ & Eno River at Hillsborough, $\mathrm{NC}$ & 186 & 0 & 0 & 6.4 & 3.1 & 2.7 & 5.6 & 26.6 & 1990 & 2013 \\
\hline S5 & Cane Creek near Orange Grove, NC & 200 & 0 & 0 & 7.8 & 6.6 & 2.1 & 5.6 & 49.5 & 1989 & 2013 \\
\hline S9 & Morgan Creek near White Cross, NC & 194 & 0 & 0 & 6.8 & 6.4 & 2.1 & 5.2 & 58.0 & 1989 & 2013 \\
\hline $\mathrm{S} 11$ & $\begin{array}{l}\text { White Oak Creek at mouth near Green } \\
\text { Level, NC }\end{array}$ & 93 & 0 & 0 & 11.5 & 2.6 & 6.6 & 11.1 & 17.6 & 2000 & 2013 \\
\hline $\mathrm{S} 13$ & $\begin{array}{l}\text { Cape Fear River at State Highway } 42 \\
\text { near Brickhaven, NC }\end{array}$ & 127 & 0 & 0 & 8.9 & 2.8 & 0.8 & 8.3 & 22.0 & 1989 & 2003 \\
\hline
\end{tabular}




\section{Trends in Water Quality of Streams and Reservoirs Used for Water Supply in the Triangle Area of NC, 1989-2013}

Table 6. Statistical summary of water-quality properties and constituents compiled for trend analysis in the Triangle area of North Carolina, by stream site.-Continued

[Summary statistics for constituents with censored data were determined by use of the Kaplan-Meier technique (Helsel, 2005). Gray shading indicates that more than 20 percent of the data for a constituent were censored. Abbreviations: $\mu \mathrm{S} / \mathrm{cm}$, microsiemens per centimeter; ${ }^{\circ} \mathrm{C}$, degree Celsius; diss., dissolved; mg/L, milligram per liter; N, nitrogen; P, phosphorus; <, less than]

\begin{tabular}{|c|c|c|c|c|c|c|c|c|c|c|c|}
\hline $\begin{array}{l}\text { Map no. } \\
\text { (fig. 1) }\end{array}$ & USGS station name & $\begin{array}{c}\text { Number of } \\
\text { observations }\end{array}$ & $\begin{array}{l}\text { Number } \\
\text { censored }\end{array}$ & $\begin{array}{l}\text { Percent } \\
\text { censored }\end{array}$ & Mean & $\begin{array}{l}\text { Standard } \\
\text { deviation }\end{array}$ & Minimum & $\begin{array}{c}\text { 50th } \\
\text { percentile } \\
\text { (median) }\end{array}$ & Maximum & Start year & End year \\
\hline \multicolumn{12}{|c|}{ Suspended solids (mg/L) } \\
\hline $\mathrm{S} 2$ & Eno River near Durham, NC & 195 & 38 & 19.5 & 9.6 & 21.6 & $<1.0$ & 5.0 & 275 & 1989 & 2013 \\
\hline $\mathrm{S} 3$ & $\begin{array}{l}\text { Little River at SR } 1461 \text { near Orange } \\
\text { Factory, NC }\end{array}$ & 253 & 88 & 34.8 & 14 & 49 & $<1.0$ & 3.0 & 510 & 1989 & 2013 \\
\hline S4 & Flat River at Bahama, NC & 138 & 23 & 16.7 & 15 & 53 & $<1.0$ & 5.0 & 460 & 1989 & 2011 \\
\hline S6 & Haw River near Bynum, NC & 455 & 106 & 23.3 & 16 & 41 & $<1.0$ & 6.0 & 570 & 1989 & 2013 \\
\hline S7 & New Hope Creek near Blands, NC & 485 & 39 & 8.0 & 25 & 27 & $<1.0$ & 18 & 280 & 1989 & 2013 \\
\hline $\mathrm{S} 8$ & $\begin{array}{l}\text { Northeast Creek at SR } 1100 \text { near } \\
\text { Genlee, NC }\end{array}$ & 338 & 62 & 18.3 & 22 & 38 & $<1.0$ & 12 & 558 & 1989 & 2013 \\
\hline $\mathrm{S} 10$ & Morgan Creek near Farrington, NC & 487 & 84 & 17.2 & 16 & 20 & $<1.0$ & 9.0 & 243 & 1989 & 2013 \\
\hline $\mathrm{S} 12$ & $\begin{array}{l}\text { Haw River below B. Everett Jordan } \\
\text { Dam near Moncure, NC }\end{array}$ & 150 & 10 & 6.7 & 13 & 11 & 1.0 & 9.0 & 64 & 1989 & 2013 \\
\hline $\mathrm{S} 13$ & $\begin{array}{l}\text { Cape Fear River at State Highway } 42 \\
\text { near Brickhaven, NC }\end{array}$ & 278 & 2 & 0.7 & 16 & 24 & $<1.0$ & 10 & 225 & 1992 & 2012 \\
\hline \multicolumn{12}{|c|}{ Suspended sediment (mg/L) } \\
\hline $\mathrm{S} 1$ & Eno River at Hillsborough, NC & 180 & 0 & 0 & 26 & 63 & 1 & 8 & 546 & 1990 & 2013 \\
\hline S4 & Flat River at Bahama, NC & 164 & 0 & 0 & 48 & 84 & 1 & 11 & 581 & 1989 & 2011 \\
\hline S5 & Cane Creek near Orange Grove, NC & 192 & 0 & 0 & 47 & 169 & 1 & 7 & 1,330 & 1989 & 2013 \\
\hline S9 & Morgan Creek near White Cross, NC & 187 & 0 & 0 & 26 & 85 & 1 & 7 & 640 & 1989 & 2013 \\
\hline S11 & $\begin{array}{l}\text { White Oak Creek at mouth near Green } \\
\text { Level, NC }\end{array}$ & 91 & 0 & 0 & 35 & 59 & 3 & 12 & 351 & 2000 & 2013 \\
\hline $\mathrm{S} 13$ & $\begin{array}{l}\text { Cape Fear River at State Highway } 42 \\
\text { near Brickhaven, NC }\end{array}$ & 114 & 0 & 0 & 30 & 46 & 4 & 16 & 290 & 1989 & 2003 \\
\hline
\end{tabular}


Table 7. Statistical summary of water-quality properties and constituents compiled for trend analysis in the Triangle area of North Carolina, by lake site.

[Summary statistics for constituents with censored data were determined by use of the Kaplan-Meier technique (Helsel, 2005). Gray shading indicates that more than 20 percent of the data for a constituent were censored. Abbreviations: $\mu \mathrm{S} / \mathrm{cm}$, microsiemens per centimeter; ${ }^{\circ} \mathrm{C}$, degree Celsius; $\mathrm{m}$, meter; diss., dissolved; $\mathrm{mg} / \mathrm{L}$, milligram per liter; N, nitrogen; $\mathrm{P}$, phosphorus; $\mu \mathrm{g} / \mathrm{L}$, microgram per liter; <, less than]

\begin{tabular}{|c|c|c|c|c|c|c|c|c|c|c|c|}
\hline $\begin{array}{l}\text { Map no. } \\
\text { (fig. 1) }\end{array}$ & USGS station name & $\begin{array}{c}\begin{array}{c}\text { Number } \\
\text { of } \\
\text { observations }\end{array}\end{array}$ & $\begin{array}{l}\text { Number } \\
\text { censored }\end{array}$ & $\begin{array}{l}\text { Percent } \\
\text { censored }\end{array}$ & Mean & $\begin{array}{l}\text { Standard } \\
\text { deviation }\end{array}$ & Minimum & $\begin{array}{c}\text { 50th } \\
\text { percentile } \\
\text { (median) }\end{array}$ & Maximum & Start year & End year \\
\hline \multicolumn{12}{|c|}{ Specific conductance $\left(\mu \mathrm{S} / \mathrm{cm}\right.$ at $\left.25^{\circ} \mathrm{C}\right)$} \\
\hline L1 & $\begin{array}{l}\text { Little River Reservoir at Dam near } \\
\text { Bahama, NC }\end{array}$ & 106 & 0 & 0 & 74 & 10 & 45 & 73 & 99 & 1989 & 2013 \\
\hline L2 & Lake Michie at Dam near Bahama, $\mathrm{NC}$ & 106 & 0 & 0 & 70 & 11 & 44 & 70 & 100 & 1989 & 2013 \\
\hline L3 & $\begin{array}{l}\text { Cane Creek Reservoir at Dam near } \\
\text { White Cross, NC }\end{array}$ & 106 & 0 & 0 & 76 & 10 & 42 & 76 & 111 & 1989 & 2013 \\
\hline L4 & $\begin{array}{l}\text { Jordan Lake, Haw River arm near } \\
\text { Hanks Chapel, NC }\end{array}$ & 103 & 0 & 0 & 196 & 70 & 85 & 192 & 453 & 1991 & 2013 \\
\hline L5 & $\begin{array}{l}\text { University Lake at Intakes near } \\
\text { Chapel Hill, NC }\end{array}$ & 106 & 0 & 0 & 95 & 16 & 66 & 93 & 186 & 1989 & 2013 \\
\hline L6 & $\begin{array}{l}\text { Jordan Lake at Buoy } 12 \text { at Farrington, } \\
\text { NC }\end{array}$ & 97 & 0 & 0 & 172 & 41 & 74 & 166 & 268 & 1993 & 2013 \\
\hline L7 & $\begin{array}{l}\text { Jordan Lake above U.S. Highway } 64 \\
\text { at Wilsonville, NC }\end{array}$ & 132 & 0 & 0 & 158 & 32 & 80 & 157 & 218 & 1991 & 2013 \\
\hline L8 & $\begin{array}{l}\text { Jordan Lake at Bells Landing near } \\
\text { Griffins Crossroads, NC }\end{array}$ & 89 & 0 & 0 & 158 & 29 & 83 & 159 & 214 & 1991 & 2013 \\
\hline \multicolumn{12}{|c|}{ Calcium, diss. (mg/L) } \\
\hline L1 & $\begin{array}{l}\text { Little River Reservoir at Dam near } \\
\text { Bahama, NC }\end{array}$ & 106 & 0 & 0 & 5.70 & 0.77 & 3.41 & 5.76 & 8.20 & 1989 & 2013 \\
\hline L2 & Lake Michie at Dam near Bahama, NC & 106 & 0 & 0 & 4.97 & 0.66 & 2.86 & 5.00 & 6.46 & 1989 & 2013 \\
\hline L3 & $\begin{array}{l}\text { Cane Creek Reservoir at Dam near } \\
\text { White Cross, NC }\end{array}$ & 106 & 0 & 0 & 5.87 & 0.84 & 3.56 & 5.81 & 9.60 & 1989 & 2013 \\
\hline L4 & $\begin{array}{l}\text { Jordan Lake, Haw River arm near } \\
\text { Hanks Chapel, NC }\end{array}$ & 104 & 0 & 0 & 8.08 & 1.17 & 5.57 & 7.98 & 10.8 & 1991 & 2013 \\
\hline L5 & $\begin{array}{l}\text { University Lake at Intakes near } \\
\text { Chapel Hill, NC }\end{array}$ & 106 & 0 & 0 & 7.62 & 1.19 & 5.38 & 7.55 & 12.0 & 1989 & 2013 \\
\hline L6 & $\begin{array}{l}\text { Jordan Lake at Buoy } 12 \text { at Farrington, } \\
\text { NC }\end{array}$ & 98 & 0 & 0 & 8.54 & 1.16 & 5.20 & 8.49 & 11.7 & 1993 & 2013 \\
\hline L7 & $\begin{array}{l}\text { Jordan Lake above U.S. Highway } 64 \\
\text { at Wilsonville, NC }\end{array}$ & 106 & 0 & 0 & 7.66 & 0.96 & 5.10 & 7.58 & 9.59 & 1991 & 2013 \\
\hline L8 & $\begin{array}{l}\text { Jordan Lake at Bells Landing near } \\
\text { Griffins Crossroads, NC }\end{array}$ & 90 & 0 & 0 & 7.51 & 0.90 & 5.02 & 7.48 & 9.49 & 1991 & 2013 \\
\hline \multicolumn{12}{|c|}{ Magnesium, diss. (mg/L) } \\
\hline L1 & $\begin{array}{l}\text { Little River Reservoir at Dam near } \\
\text { Bahama, NC }\end{array}$ & 106 & 0 & 0 & 2.28 & 0.28 & 1.46 & 2.31 & 2.90 & 1989 & 2013 \\
\hline L2 & Lake Michie at Dam near Bahama, NC & 106 & 0 & 0 & 2.17 & 0.30 & 1.24 & 2.20 & 2.82 & 1989 & 2013 \\
\hline L3 & $\begin{array}{l}\text { Cane Creek Reservoir at Dam near } \\
\text { White Cross, NC }\end{array}$ & 106 & 0 & 0 & 2.39 & 0.29 & 1.46 & 2.40 & 3.80 & 1989 & 2013 \\
\hline L4 & $\begin{array}{l}\text { Jordan Lake, Haw River arm near } \\
\text { Hanks Chapel, NC }\end{array}$ & 104 & 0 & 0 & 3.21 & 0.47 & 2.24 & 3.15 & 4.25 & 1991 & 2013 \\
\hline L5 & $\begin{array}{l}\text { University Lake at Intakes near } \\
\text { Chapel Hill, NC }\end{array}$ & 106 & 0 & 0 & 2.63 & 0.34 & 1.90 & 2.63 & 3.73 & 1989 & 2013 \\
\hline L6 & $\begin{array}{l}\text { Jordan Lake at Buoy } 12 \text { at Farrington, } \\
\text { NC }\end{array}$ & 98 & 0 & 0 & 2.90 & 0.42 & 1.75 & 2.87 & 3.95 & 1993 & 2013 \\
\hline L7 & $\begin{array}{l}\text { Jordan Lake above U.S. Highway } 64 \\
\text { at Wilsonville, NC }\end{array}$ & 106 & 0 & 0 & 2.78 & 0.36 & 1.80 & 2.80 & 3.53 & 1991 & 2013 \\
\hline L8 & $\begin{array}{l}\text { Jordan Lake at Bells Landing near } \\
\text { Griffins Crossroads, NC }\end{array}$ & 90 & 0 & 0 & 2.83 & 0.33 & 1.88 & 2.81 & 3.52 & 1991 & 2013 \\
\hline
\end{tabular}


Table 7. Statistical summary of water-quality properties and constituents compiled for trend analysis in the Triangle area of North Carolina, by lake site.-Continued

[Summary statistics for constituents with censored data were determined by use of the Kaplan-Meier technique (Helsel, 2005). Gray shading indicates that more than 20 percent of the data for a constituent were censored. Abbreviations: $\mu \mathrm{S} / \mathrm{cm}$, microsiemens per centimeter; ${ }^{\circ} \mathrm{C}$, degree Celsius; $\mathrm{m}$, meter; diss., dissolved; $\mathrm{mg} / \mathrm{L}$, milligram per liter; $\mathrm{N}$, nitrogen; $\mathrm{P}$, phosphorus; $\mu \mathrm{g} / \mathrm{L}$, microgram per liter; $<$, less than]

\begin{tabular}{|c|c|c|c|c|c|c|c|c|c|c|c|}
\hline $\begin{array}{l}\text { Map no. } \\
\text { (fig. 1) }\end{array}$ & USGS station name & $\begin{array}{c}\text { Number } \\
\text { of } \\
\text { observations }\end{array}$ & $\begin{array}{l}\text { Number } \\
\text { censored }\end{array}$ & $\begin{array}{l}\text { Percent } \\
\text { censored }\end{array}$ & Mean & $\begin{array}{l}\text { Standard } \\
\text { deviation }\end{array}$ & Minimum & $\begin{array}{c}\text { 50th } \\
\text { percentile } \\
\text { (median) }\end{array}$ & Maximum & Start year & End year \\
\hline \multicolumn{12}{|c|}{ Potassium, diss. (mg/L) } \\
\hline $\mathrm{L} 1$ & $\begin{array}{l}\text { Little River Reservoir at Dam near } \\
\text { Bahama, NC }\end{array}$ & 106 & 0 & 0 & 1.87 & 0.33 & 1.20 & 1.80 & 2.83 & 1989 & 2013 \\
\hline $\mathrm{L} 2$ & Lake Michie at Dam near Bahama, NC & 106 & 0 & 0 & 1.96 & 0.40 & 1.20 & 1.90 & 2.97 & 1989 & 2013 \\
\hline L3 & $\begin{array}{l}\text { Cane Creek Reservoir at Dam near } \\
\text { White Cross, NC }\end{array}$ & 106 & 0 & 0 & 2.26 & 0.45 & 1.42 & 2.15 & 3.68 & 1989 & 2013 \\
\hline L4 & $\begin{array}{l}\text { Jordan Lake, Haw River arm near } \\
\text { Hanks Chapel, NC }\end{array}$ & 104 & 0 & 0 & 3.87 & 1.10 & 2.11 & 3.68 & 8.07 & 1991 & 2013 \\
\hline L5 & $\begin{array}{l}\text { University Lake at Intakes near } \\
\text { Chapel Hill, NC }\end{array}$ & 106 & 0 & 0 & 2.30 & 0.50 & 1.34 & 2.22 & 3.52 & 1989 & 2013 \\
\hline L6 & $\begin{array}{l}\text { Jordan Lake at Buoy } 12 \text { at Farrington, } \\
\text { NC }\end{array}$ & 98 & 0 & 0 & 3.66 & 0.85 & 1.70 & 3.64 & 5.75 & 1993 & 2013 \\
\hline L7 & $\begin{array}{l}\text { Jordan Lake above U.S. Highway } 64 \\
\text { at Wilsonville, NC }\end{array}$ & 106 & 0 & 0 & 3.31 & 0.62 & 1.90 & 3.26 & 4.49 & 1991 & 2013 \\
\hline L8 & $\begin{array}{l}\text { Jordan Lake at Bells Landing near } \\
\text { Griffins Crossroads, NC }\end{array}$ & 90 & 0 & 0 & 3.36 & 0.56 & 1.90 & 3.40 & 4.32 & 1991 & 2013 \\
\hline \multicolumn{12}{|c|}{ Sodium, diss. (mg/L) } \\
\hline L1 & $\begin{array}{l}\text { Little River Reservoir at Dam near } \\
\text { Bahama, NC }\end{array}$ & 106 & 0 & 0 & 4.20 & 0.82 & 2.21 & 4.20 & 5.89 & 1989 & 2013 \\
\hline L2 & Lake Michie at Dam near Bahama, NC & 106 & 0 & 0 & 4.41 & 0.88 & 1.76 & 4.43 & 6.55 & 1989 & 2013 \\
\hline L3 & $\begin{array}{l}\text { Cane Creek Reservoir at Dam near } \\
\text { White Cross, NC }\end{array}$ & 106 & 0 & 0 & 4.04 & 0.62 & 2.38 & 4.03 & 5.80 & 1989 & 2013 \\
\hline L4 & $\begin{array}{l}\text { Jordan Lake, Haw River arm near } \\
\text { Hanks Chapel, NC }\end{array}$ & 104 & 0 & 0 & 23.0 & 12.0 & 5.84 & 21.8 & 64.1 & 1991 & 2013 \\
\hline L5 & $\begin{array}{l}\text { University Lake at Intakes near } \\
\text { Chapel Hill, NC }\end{array}$ & 106 & 0 & 0 & 5.78 & 1.14 & 3.20 & 5.69 & 8.16 & 1989 & 2013 \\
\hline L6 & $\begin{array}{l}\text { Jordan Lake at Buoy } 12 \text { at Farrington, } \\
\text { NC }\end{array}$ & 98 & 0 & 0 & 18.9 & 6.9 & 5.07 & 18.2 & 45.1 & 1993 & 2013 \\
\hline L7 & $\begin{array}{l}\text { Jordan Lake above U.S. Highway } 64 \\
\text { at Wilsonville, NC }\end{array}$ & 106 & 0 & 0 & 16.4 & 4.9 & 6.90 & 16.0 & 26.8 & 1991 & 2013 \\
\hline L8 & $\begin{array}{l}\text { Jordan Lake at Bells Landing near } \\
\text { Griffins Crossroads, NC }\end{array}$ & 90 & 0 & 0 & 17.1 & 4.6 & 7.00 & 17.0 & 27.0 & 1991 & 2013 \\
\hline \multicolumn{12}{|c|}{ Chloride, diss. (mg/L) } \\
\hline L1 & $\begin{array}{l}\text { Little River Reservoir at Dam near } \\
\text { Bahama, NC }\end{array}$ & 105 & 0 & 0 & 4.94 & 1.09 & 1.98 & 4.90 & 7.45 & 1989 & 2013 \\
\hline $\mathrm{L} 2$ & Lake Michie at Dam near Bahama, NC & 103 & 0 & 0 & 4.87 & 0.93 & 2.29 & 4.72 & 7.19 & 1989 & 2013 \\
\hline L3 & $\begin{array}{l}\text { Cane Creek Reservoir at Dam near } \\
\text { White Cross, NC }\end{array}$ & 105 & 0 & 0 & 5.28 & 0.74 & 3.10 & 5.30 & 7.03 & 1989 & 2013 \\
\hline L4 & $\begin{array}{l}\text { Jordan Lake, Haw River arm near } \\
\text { Hanks Chapel, NC }\end{array}$ & 103 & 0 & 0 & 18.4 & 8.9 & 5.34 & 16.9 & 47.0 & 1991 & 2013 \\
\hline L5 & $\begin{array}{l}\text { University Lake at Intakes near } \\
\text { Chapel Hill, NC }\end{array}$ & 105 & 0 & 0 & 5.99 & 1.38 & 3.68 & 5.60 & 9.71 & 1989 & 2013 \\
\hline L6 & $\begin{array}{l}\text { Jordan Lake at Buoy } 12 \text { at Farrington, } \\
\text { NC }\end{array}$ & 96 & 0 & 0 & 17.3 & 5.9 & 4.50 & 16.8 & 35.1 & 1993 & 2013 \\
\hline L7 & $\begin{array}{l}\text { Jordan Lake above U.S. Highway } 64 \\
\text { at Wilsonville, NC }\end{array}$ & 105 & 0 & 0 & 14.9 & 4.3 & 6.41 & 14.3 & 25.1 & 1991 & 2013 \\
\hline L8 & $\begin{array}{l}\text { Jordan Lake at Bells Landing near } \\
\text { Griffins Crossroads, NC }\end{array}$ & 90 & 0 & 0 & 15.2 & 4.0 & 6.40 & 14.9 & 23.9 & 1991 & 2013 \\
\hline
\end{tabular}


Table 7. Statistical summary of water-quality properties and constituents compiled for trend analysis in the Triangle area of North Carolina, by lake site.-Continued

[Summary statistics for constituents with censored data were determined by use of the Kaplan-Meier technique (Helsel, 2005). Gray shading indicates that more than 20 percent of the data for a constituent were censored. Abbreviations: $\mu \mathrm{S} / \mathrm{cm}$, microsiemens per centimeter; ${ }^{\circ} \mathrm{C}$, degree Celsius; $\mathrm{m}$, meter; diss., dissolved; $\mathrm{mg} / \mathrm{L}$, milligram per liter; N, nitrogen; $\mathrm{P}$, phosphorus; $\mu \mathrm{g} / \mathrm{L}$, microgram per liter; $<$, less than]

\begin{tabular}{|c|c|c|c|c|c|c|c|c|c|c|c|}
\hline $\begin{array}{l}\text { Map no. } \\
\text { (fig. 1) }\end{array}$ & USGS station name & $\begin{array}{c}\text { Number } \\
\text { of } \\
\text { observations }\end{array}$ & $\begin{array}{l}\text { Number } \\
\text { censored }\end{array}$ & $\begin{array}{l}\text { Percent } \\
\text { censored }\end{array}$ & Mean & $\begin{array}{l}\text { Standard } \\
\text { deviation }\end{array}$ & Minimum & $\begin{array}{c}\text { 50th } \\
\text { percentile } \\
\text { (median) }\end{array}$ & Maximum & Start year & End year \\
\hline \multicolumn{12}{|c|}{ Sulfate, diss. (mg/L) } \\
\hline L1 & $\begin{array}{l}\text { Little River Reservoir at Dam near } \\
\text { Bahama, NC }\end{array}$ & 105 & 0 & 0 & 4.13 & 1.22 & 2.11 & 3.90 & 8.27 & 1989 & 2013 \\
\hline L2 & Lake Michie at Dam near Bahama, NC & 103 & 0 & 0 & 3.97 & 1.17 & 2.19 & 3.71 & 7.86 & 1989 & 2013 \\
\hline L3 & $\begin{array}{l}\text { Cane Creek Reservoir at Dam near } \\
\text { White Cross, NC }\end{array}$ & 105 & 0 & 0 & 3.90 & 1.09 & 1.20 & 3.90 & 7.30 & 1989 & 2013 \\
\hline L4 & $\begin{array}{l}\text { Jordan Lake, Haw River arm near } \\
\text { Hanks Chapel, NC }\end{array}$ & 103 & 0 & 0 & 19.7 & 9.4 & 6.78 & 17.7 & 55.2 & 1991 & 2013 \\
\hline L5 & $\begin{array}{l}\text { University Lake at Intakes near } \\
\text { Chapel Hill, NC }\end{array}$ & 104 & 0 & 0 & 5.45 & 1.95 & 0.20 & 5.20 & 12.3 & 1989 & 2013 \\
\hline L6 & $\begin{array}{l}\text { Jordan Lake at Buoy } 12 \text { at Farrington, } \\
\text { NC }\end{array}$ & 96 & 0 & 0 & 15.8 & 5.0 & 6.92 & 15.4 & 30.4 & 1993 & 2013 \\
\hline L7 & $\begin{array}{l}\text { Jordan Lake above U.S. Highway } 64 \\
\text { at Wilsonville, NC }\end{array}$ & 104 & 0 & 0 & 14.0 & 3.4 & 6.93 & 13.9 & 21.8 & 1991 & 2013 \\
\hline L8 & $\begin{array}{l}\text { Jordan Lake at Bells Landing near } \\
\text { Griffins Crossroads, NC }\end{array}$ & 90 & 0 & 0 & 14.3 & 3.3 & 6.77 & 14.4 & 21.3 & 1991 & 2013 \\
\hline \multicolumn{12}{|c|}{ Nitrate + nitrite, diss. (mg/L as N) } \\
\hline $\mathrm{L} 1$ & $\begin{array}{l}\text { Little River Reservoir at Dam near } \\
\text { Bahama, NC }\end{array}$ & 105 & 36 & 34.3 & 0.091 & 0.101 & $<0.005$ & 0.073 & 0.470 & 1989 & 2013 \\
\hline $\mathrm{L} 2$ & Lake Michie at Dam near Bahama, NC & 106 & 51 & 48.1 & 0.061 & 0.086 & $<0.005$ & 0.012 & 0.360 & 1989 & 2013 \\
\hline L3 & $\begin{array}{l}\text { Cane Creek Reservoir at Dam near } \\
\text { White Cross, NC }\end{array}$ & 106 & 52 & 49.1 & 0.102 & 0.205 & $<0.005$ & 0.012 & 1.70 & 1989 & 2013 \\
\hline L4 & $\begin{array}{l}\text { Jordan Lake, Haw River arm near } \\
\text { Hanks Chapel, NC }\end{array}$ & 103 & 12 & 11.7 & 0.388 & 0.327 & $<0.005$ & 0.360 & 1.50 & 1991 & 2013 \\
\hline L5 & $\begin{array}{l}\text { University Lake at Intakes near } \\
\text { Chapel Hill, NC }\end{array}$ & 106 & 74 & 69.8 & 0.027 & 0.067 & $<0.005$ & 0.005 & 0.470 & 1989 & 2013 \\
\hline L6 & $\begin{array}{l}\text { Jordan Lake at Buoy } 12 \text { at Farrington, } \\
\text { NC }\end{array}$ & 98 & 50 & 51.0 & 0.071 & 0.124 & $<0.005$ & 0.011 & 0.660 & 1993 & 2013 \\
\hline L7 & $\begin{array}{l}\text { Jordan Lake above U.S. Highway } 64 \\
\text { at Wilsonville, NC }\end{array}$ & 132 & 64 & 48.5 & 0.063 & 0.099 & $<0.005$ & 0.010 & 0.630 & 1991 & 2013 \\
\hline L8 & $\begin{array}{l}\text { Jordan Lake at Bells Landing near } \\
\text { Griffins Crossroads, NC }\end{array}$ & 90 & 43 & 47.8 & 0.102 & 0.140 & $<0.005$ & 0.020 & 0.640 & 1991 & 2013 \\
\hline \multicolumn{12}{|c|}{ Ammonia, diss. (mg/L as N) } \\
\hline L1 & $\begin{array}{l}\text { Little River Reservoir at Dam near } \\
\text { Bahama, NC }\end{array}$ & 105 & 17 & 16.2 & 0.058 & 0.066 & $<0.002$ & 0.034 & 0.350 & 1989 & 2013 \\
\hline $\mathrm{L} 2$ & Lake Michie at Dam near Bahama, NC & 106 & 21 & 19.8 & 0.055 & 0.065 & $<0.002$ & 0.030 & 0.358 & 1989 & 2013 \\
\hline L3 & $\begin{array}{l}\text { Cane Creek Reservoir at Dam near } \\
\text { White Cross, NC }\end{array}$ & 106 & 21 & 19.8 & 0.048 & 0.093 & 0.002 & 0.020 & 0.650 & 1989 & 2013 \\
\hline L4 & $\begin{array}{l}\text { Jordan Lake, Haw River arm near } \\
\text { Hanks Chapel, NC }\end{array}$ & 103 & 19 & 18.4 & 0.030 & 0.030 & $<0.002$ & 0.020 & 0.194 & 1991 & 2013 \\
\hline L5 & $\begin{array}{l}\text { University Lake at Intakes near } \\
\text { Chapel Hill, NC }\end{array}$ & 106 & 35 & 33.0 & 0.057 & 0.228 & $<0.002$ & 0.012 & 2.30 & 1989 & 2013 \\
\hline L6 & $\begin{array}{l}\text { Jordan Lake at Buoy } 12 \text { at Farrington, } \\
\text { NC }\end{array}$ & 98 & 31 & 31.6 & 0.031 & 0.041 & $<0.002$ & 0.017 & 0.220 & 1993 & 2013 \\
\hline L7 & $\begin{array}{l}\text { Jordan Lake above U.S. Highway } 64 \\
\text { at Wilsonville, NC }\end{array}$ & 132 & 40 & 30.3 & 0.036 & 0.042 & $<0.002$ & 0.020 & 0.213 & 1991 & 2013 \\
\hline L8 & $\begin{array}{l}\text { Jordan Lake at Bells Landing near } \\
\text { Griffins Crossroads, NC }\end{array}$ & 90 & 26 & 28.9 & 0.033 & 0.044 & $<0.002$ & 0.013 & 0.223 & 1991 & 2013 \\
\hline
\end{tabular}


Table 7. Statistical summary of water-quality properties and constituents compiled for trend analysis in the Triangle area of North Carolina, by lake site.-Continued

[Summary statistics for constituents with censored data were determined by use of the Kaplan-Meier technique (Helsel, 2005). Gray shading indicates that more than 20 percent of the data for a constituent were censored. Abbreviations: $\mu \mathrm{S} / \mathrm{cm}$, microsiemens per centimeter; ${ }^{\circ} \mathrm{C}$, degree Celsius; $\mathrm{m}$, meter; diss., dissolved; $\mathrm{mg} / \mathrm{L}$, milligram per liter; $\mathrm{N}$, nitrogen; $\mathrm{P}$, phosphorus; $\mu \mathrm{g} / \mathrm{L}$, microgram per liter; $<$, less than]

\begin{tabular}{|c|c|c|c|c|c|c|c|c|c|c|c|}
\hline $\begin{array}{l}\text { Map no. } \\
\text { (fig. 1) }\end{array}$ & USGS station name & $\begin{array}{c}\text { Number } \\
\text { of } \\
\text { observations }\end{array}$ & $\begin{array}{l}\text { Number } \\
\text { censored }\end{array}$ & $\begin{array}{l}\text { Percent } \\
\text { censored }\end{array}$ & Mean & $\begin{array}{l}\text { Standard } \\
\text { deviation }\end{array}$ & Minimum & $\begin{array}{c}\text { 50th } \\
\text { percentile } \\
\text { (median) }\end{array}$ & Maximum & Start year & End year \\
\hline \multicolumn{12}{|c|}{ Total organic N (mg/L as N) } \\
\hline $\mathrm{L} 1$ & $\begin{array}{l}\text { Little River Reservoir at Dam near } \\
\text { Bahama, NC }\end{array}$ & 105 & 0 & 0 & 0.48 & 0.13 & 0.18 & 0.47 & 0.86 & 1989 & 2013 \\
\hline L2 & Lake Michie at Dam near Bahama, NC & 106 & 0 & 0 & 0.52 & 0.13 & 0.28 & 0.51 & 0.96 & 1989 & 2013 \\
\hline L3 & $\begin{array}{l}\text { Cane Creek Reservoir at Dam near } \\
\text { White Cross, NC }\end{array}$ & 106 & 0 & 0 & 0.62 & 0.23 & 0.29 & 0.58 & 1.6 & 1989 & 2013 \\
\hline L4 & $\begin{array}{l}\text { Jordan Lake, Haw River arm near } \\
\text { Hanks Chapel, NC }\end{array}$ & 103 & 1 & 1.0 & 0.79 & 0.29 & $<0.18$ & 0.75 & 2.0 & 1991 & 2013 \\
\hline L5 & $\begin{array}{l}\text { University Lake at Intakes near } \\
\text { Chapel Hill, NC }\end{array}$ & 106 & 1 & 0.9 & 0.72 & 0.29 & $<0.18$ & 0.65 & 2.2 & 1989 & 2013 \\
\hline L6 & $\begin{array}{l}\text { Jordan Lake at Buoy } 12 \text { at Farrington, } \\
\text { NC }\end{array}$ & 98 & 0 & 0 & 0.95 & 0.36 & 0.31 & 0.90 & 3.4 & 1993 & 2013 \\
\hline L7 & $\begin{array}{l}\text { Jordan Lake above U.S. Highway } 64 \\
\text { at Wilsonville, NC }\end{array}$ & 132 & 0 & 0 & 0.71 & 0.14 & 0.32 & 0.71 & 1.2 & 1991 & 2013 \\
\hline L8 & $\begin{array}{l}\text { Jordan Lake at Bells Landing near } \\
\text { Griffins Crossroads, NC }\end{array}$ & 90 & 0 & 0 & 0.67 & 0.12 & 0.38 & 0.66 & 1.2 & 1991 & 2013 \\
\hline \multicolumn{12}{|c|}{ Total N (mg/L as N) } \\
\hline L1 & $\begin{array}{l}\text { Little River Reservoir at Dam near } \\
\text { Bahama, NC }\end{array}$ & 105 & 0 & 0 & 0.64 & 0.16 & 0.35 & 0.61 & 1.3 & 1989 & 2013 \\
\hline L2 & Lake Michie at Dam near Bahama, NC & 106 & 0 & 0 & 0.65 & 0.15 & 0.35 & 0.64 & 1.2 & 1989 & 2013 \\
\hline L3 & $\begin{array}{l}\text { Cane Creek Reservoir at Dam near } \\
\text { White Cross, NC }\end{array}$ & 106 & 0 & 0 & 0.78 & 0.29 & 0.35 & 0.73 & 2.1 & 1989 & 2013 \\
\hline L4 & $\begin{array}{l}\text { Jordan Lake, Haw River arm near } \\
\text { Hanks Chapel, NC }\end{array}$ & 103 & 0 & 0 & 1.2 & 0.37 & 0.47 & 1.1 & 2.6 & 1991 & 2013 \\
\hline L5 & $\begin{array}{l}\text { University Lake at Intakes near } \\
\text { Chapel Hill, NC }\end{array}$ & 106 & 1 & 0.9 & 0.82 & 0.39 & $<0.25$ & 0.75 & 3.2 & 1989 & 2013 \\
\hline L6 & $\begin{array}{l}\text { Jordan Lake at Buoy } 12 \text { at Farrington, } \\
\text { NC }\end{array}$ & 98 & 0 & 0 & 1.1 & 0.35 & 0.42 & 1.0 & 3.4 & 1993 & 2013 \\
\hline L7 & $\begin{array}{l}\text { Jordan Lake above U.S. Highway } 64 \\
\text { at Wilsonville, NC }\end{array}$ & 132 & 0 & 0 & 0.82 & 0.16 & 0.45 & 0.81 & 1.3 & 1991 & 2013 \\
\hline L8 & $\begin{array}{l}\text { Jordan Lake at Bells Landing near } \\
\text { Griffins Crossroads, NC }\end{array}$ & 90 & 0 & 0 & 0.82 & 0.19 & 0.45 & 0.80 & 1.6 & 1991 & 2013 \\
\hline \multicolumn{12}{|c|}{ Total P (mg/L as P) } \\
\hline $\mathrm{L} 1$ & $\begin{array}{l}\text { Little River Reservoir at Dam near } \\
\text { Bahama, NC }\end{array}$ & 103 & 11 & 10.7 & 0.029 & 0.014 & $<0.010$ & 0.030 & 0.082 & 1989 & 2013 \\
\hline $\mathrm{L} 2$ & Lake Michie at Dam near Bahama, NC & 104 & 15 & 14.4 & 0.034 & 0.015 & $<0.010$ & 0.030 & 0.080 & 1989 & 2013 \\
\hline L3 & $\begin{array}{l}\text { Cane Creek Reservoir at Dam near } \\
\text { White Cross, NC }\end{array}$ & 103 & 18 & 17.5 & 0.030 & 0.025 & 0.008 & 0.029 & 0.230 & 1989 & 2013 \\
\hline $\mathrm{L} 4$ & $\begin{array}{l}\text { Jordan Lake, Haw River arm near } \\
\text { Hanks Chapel, NC }\end{array}$ & 101 & 2 & 2.0 & 0.091 & 0.044 & $<0.010$ & 0.080 & 0.250 & 1991 & 2013 \\
\hline L5 & $\begin{array}{l}\text { University Lake at Intakes near } \\
\text { Chapel Hill, NC }\end{array}$ & 103 & 6 & 5.8 & 0.046 & 0.017 & $<0.010$ & 0.045 & 0.093 & 1989 & 2013 \\
\hline L6 & $\begin{array}{l}\text { Jordan Lake at Buoy } 12 \text { at Farrington, } \\
\text { NC }\end{array}$ & 96 & 1 & 1.0 & 0.076 & 0.034 & 0.010 & 0.074 & 0.300 & 1993 & 2013 \\
\hline L7 & $\begin{array}{l}\text { Jordan Lake above U.S. Highway } 64 \\
\text { at Wilsonville, NC }\end{array}$ & 130 & 4 & 3.1 & 0.040 & 0.011 & $<0.010$ & 0.040 & 0.072 & 1991 & 2013 \\
\hline L8 & $\begin{array}{l}\text { Jordan Lake at Bells Landing near } \\
\text { Griffins Crossroads, NC }\end{array}$ & 88 & 4 & 4.5 & 0.037 & 0.012 & $<0.010$ & 0.037 & 0.092 & 1991 & 2013 \\
\hline
\end{tabular}


Table 7. Statistical summary of water-quality properties and constituents compiled for trend analysis in the Triangle area of North Carolina, by lake site.-Continued

[Summary statistics for constituents with censored data were determined by use of the Kaplan-Meier technique (Helsel, 2005). Gray shading indicates that more than 20 percent of the data for a constituent were censored. Abbreviations: $\mu \mathrm{S} / \mathrm{cm}$, microsiemens per centimeter; ${ }^{\circ} \mathrm{C}$, degree Celsius; $\mathrm{m}$, meter; diss., dissolved; $\mathrm{mg} / \mathrm{L}$, milligram per liter; N, nitrogen; $\mathrm{P}$, phosphorus; $\mu \mathrm{g} / \mathrm{L}$, microgram per liter; $<$, less than]

\begin{tabular}{|c|c|c|c|c|c|c|c|c|c|c|c|}
\hline $\begin{array}{l}\text { Map no. } \\
\text { (fig. 1) }\end{array}$ & USGS station name & $\begin{array}{c}\text { Number } \\
\text { of } \\
\text { observations }\end{array}$ & $\begin{array}{l}\text { Number } \\
\text { censored }\end{array}$ & $\begin{array}{l}\text { Percent } \\
\text { censored }\end{array}$ & Mean & $\begin{array}{l}\text { Standard } \\
\text { deviation }\end{array}$ & Minimum & $\begin{array}{c}\text { 50th } \\
\text { percentile } \\
\text { (median) }\end{array}$ & Maximum & Start year & End year \\
\hline \multicolumn{12}{|c|}{ Total organic carbon (mg/L) } \\
\hline L1 & $\begin{array}{l}\text { Little River Reservoir at Dam near } \\
\text { Bahama, NC }\end{array}$ & 106 & 0 & 0 & 7.7 & 1.8 & 4.7 & 7.5 & 12.4 & 1989 & 2013 \\
\hline $\mathrm{L} 2$ & Lake Michie at Dam near Bahama, NC & 103 & 0 & 0 & 8.6 & 2.1 & 2.1 & 8.3 & 16.5 & 1989 & 2013 \\
\hline L3 & $\begin{array}{l}\text { Cane Creek Reservoir at Dam near } \\
\text { White Cross, NC }\end{array}$ & 105 & 0 & 0 & 7.9 & 2.0 & 2.9 & 7.7 & 16.0 & 1989 & 2013 \\
\hline L4 & $\begin{array}{l}\text { Jordan Lake, Haw River arm near } \\
\text { Hanks Chapel, NC }\end{array}$ & 101 & 0 & 0 & 8.6 & 1.8 & 4.7 & 8.4 & 14.7 & 1991 & 2013 \\
\hline L5 & $\begin{array}{l}\text { University Lake at Intakes near } \\
\text { Chapel Hill, NC }\end{array}$ & 106 & 0 & 0 & 8.5 & 2.0 & 4.8 & 8.6 & 15.0 & 1989 & 2013 \\
\hline L6 & $\begin{array}{l}\text { Jordan Lake at Buoy } 12 \text { at Farrington, } \\
\text { NC }\end{array}$ & 96 & 0 & 0 & 10.7 & 1.4 & 8.0 & 10.6 & 15.5 & 1993 & 2013 \\
\hline L7 & $\begin{array}{l}\text { Jordan Lake above U.S. Highway } 64 \\
\text { at Wilsonville, NC }\end{array}$ & 105 & 0 & 0 & 9.0 & 1.5 & 2.3 & 8.9 & 17.0 & 1991 & 2013 \\
\hline L8 & $\begin{array}{l}\text { Jordan Lake at Bells Landing near } \\
\text { Griffins Crossroads, NC }\end{array}$ & 88 & 0 & 0 & 8.4 & 1.0 & 5.8 & 8.3 & 10.9 & 1991 & 2013 \\
\hline \multicolumn{12}{|c|}{ Transparency, Secchi (m) } \\
\hline $\mathrm{L} 1$ & $\begin{array}{l}\text { Little River Reservoir at Dam near } \\
\text { Bahama, NC }\end{array}$ & 86 & 0 & 0 & 1.09 & 0.36 & 0.50 & 1.00 & 2.50 & 1993 & 2013 \\
\hline $\mathrm{L} 2$ & Lake Michie at Dam near Bahama, NC & 86 & 0 & 0 & 0.95 & 0.36 & 0.30 & 0.88 & 2.50 & 1993 & 2013 \\
\hline L3 & $\begin{array}{l}\text { Cane Creek Reservoir at Dam near } \\
\text { White Cross, NC }\end{array}$ & 85 & 0 & 0 & 1.30 & 0.54 & 0.35 & 1.20 & 3.10 & 1993 & 2013 \\
\hline $\mathrm{L} 4$ & $\begin{array}{l}\text { Jordan Lake, Haw River arm near } \\
\text { Hanks Chapel, NC }\end{array}$ & 98 & 0 & 0 & 0.66 & 0.21 & 0.20 & 0.65 & 1.40 & 1993 & 2013 \\
\hline L5 & $\begin{array}{l}\text { University Lake at Intakes near } \\
\text { Chapel Hill, NC }\end{array}$ & 85 & 0 & 0 & 0.72 & 0.23 & 0.25 & 0.70 & 1.45 & 1993 & 2013 \\
\hline L6 & $\begin{array}{l}\text { Jordan Lake at Buoy } 12 \text { at Farrington, } \\
\text { NC }\end{array}$ & 98 & 0 & 0 & 0.50 & 0.16 & 0.10 & 0.50 & 1.40 & 1993 & 2013 \\
\hline L7 & $\begin{array}{l}\text { Jordan Lake above U.S. Highway } 64 \\
\text { at Wilsonville, NC }\end{array}$ & 124 & 0 & 0 & 0.78 & 0.21 & 0.40 & 0.73 & 1.60 & 1993 & 2013 \\
\hline L8 & $\begin{array}{l}\text { Jordan Lake at Bells Landing near } \\
\text { Griffins Crossroads, NC }\end{array}$ & 81 & 0 & 0 & 0.82 & 0.21 & 0.45 & 0.80 & 1.40 & 1993 & 2013 \\
\hline \multicolumn{12}{|c|}{ Chlorophyll a, phytoplankton ( $\mu \mathrm{g} / \mathrm{L})$} \\
\hline L1 & $\begin{array}{l}\text { Little River Reservoir at Dam near } \\
\text { Bahama, NC }\end{array}$ & 85 & 0 & 0 & 10.0 & 10.5 & 1.0 & 7.5 & 75.5 & 1992 & 2013 \\
\hline $\mathrm{L} 2$ & Lake Michie at Dam near Bahama, NC & 85 & 1 & 1.2 & 10.0 & 7.7 & $<0.1$ & 8.3 & 37.6 & 1992 & 2013 \\
\hline L3 & $\begin{array}{l}\text { Cane Creek Reservoir at Dam near } \\
\text { White Cross, NC }\end{array}$ & 85 & 0 & 0 & 13.4 & 14.1 & 0.2 & 8.9 & 87.8 & 1992 & 2013 \\
\hline L4 & $\begin{array}{l}\text { Jordan Lake, Haw River arm near } \\
\text { Hanks Chapel, NC }\end{array}$ & 94 & 0 & 0 & 19.1 & 15.5 & 0.8 & 14.8 & 64.3 & 1992 & 2013 \\
\hline L5 & $\begin{array}{l}\text { University Lake at Intakes near } \\
\text { Chapel Hill, NC }\end{array}$ & 84 & 0 & 0 & 24.0 & 23.9 & 1.2 & 17.6 & 165.0 & 1992 & 2013 \\
\hline L6 & $\begin{array}{l}\text { Jordan Lake at Buoy } 12 \text { at Farrington, } \\
\text { NC }\end{array}$ & 90 & 0 & 0 & 30.2 & 17.7 & 0.9 & 27.8 & 74.5 & 1993 & 2013 \\
\hline L7 & $\begin{array}{l}\text { Jordan Lake above U.S. Highway } 64 \\
\text { at Wilsonville, NC }\end{array}$ & 120 & 0 & 0 & 19.4 & 10.9 & 1.2 & 18.1 & 52.3 & 1992 & 2013 \\
\hline L8 & $\begin{array}{l}\text { Jordan Lake at Bells Landing near } \\
\text { Griffins Crossroads, NC }\end{array}$ & 79 & 0 & 0 & 16.1 & 9.4 & 2.4 & 14.8 & 50.3 & 1992 & 2013 \\
\hline
\end{tabular}


Table 8. Summary of trend results based on data collected during 1989-2013 for specific conductance, major ions, and nutrients at stream and lake sites assessed in the Triangle area of North Carolina.

[Bold red font indicates statistically significant (at p-value less than 0.05) upward trend results, and bold blue font indicates statistically significant downward trend results. Gray shading indicates no trend results are presented due to model error or because more than 20 percent of the data were censored. Abbreviations: USGS, U.S. Geological Survey; NC, North Carolina; $\mu \mathrm{S} / \mathrm{cm}$, microsiemens per centimeter; ${ }^{\circ} \mathrm{C}$, degree Celsius; <, less than; diss., dissolved; $\mathrm{mg} / \mathrm{L}$, milligram per liter; na, not applicable; $\mathrm{N}$, nitrogen; $\mathrm{P}$, phosphorus]

\begin{tabular}{|c|c|c|c|c|c|c|c|}
\hline $\begin{array}{l}\text { Map no. } \\
\text { (fig. 1) }\end{array}$ & USGS station name & Best-fit trend model & $\begin{array}{l}\text { Trend } \\
\text { period }\end{array}$ & $\begin{array}{l}\text { Percent } \\
\text { change }\end{array}$ & p-value & $\begin{array}{c}\text { Fitted annual } \\
\text { median } \\
\text { concentration for } \\
\text { first year } \\
\text { in period }\end{array}$ & $\begin{array}{c}\text { Fitted annual } \\
\text { median } \\
\text { concentration for } \\
\text { last year } \\
\text { in period }\end{array}$ \\
\hline \multicolumn{8}{|c|}{ Specific conductance $\left(\mu \mathrm{S} / \mathrm{cm}\right.$ at $\left.25^{\circ} \mathrm{C}\right)$} \\
\hline $\mathrm{S} 1$ & Eno River at Hillsborough, NC & 1-period & 1990-2013 & 6.2 & 0.0309 & 88 & 94 \\
\hline $\mathrm{S} 2$ & Eno River near Durham, NC & 1-period & 1989-2013 & -25.5 & 0.0019 & 156 & 118 \\
\hline S3 & Little River at SR 1461 near Orange Factory, NC & 1-period & 1989-2013 & 16.3 & 0.0002 & 79 & 92 \\
\hline S4 & Flat River at Bahama, $\mathrm{NC}$ & 1-period & $1989-2011$ & 8.6 & 0.0838 & 76 & 82 \\
\hline S5 & Cane Creek near Orange Grove, NC & 1-period & 1989-2013 & -4.0 & 0.2318 & 92 & 88 \\
\hline S6 & Haw River near Bynum, NC & 1-period & 1989-2013 & 14.7 & 0.0489 & 170 & 194 \\
\hline S7 & New Hope Creek near Blands, NC & 1-period & 1989-2013 & 43.2 & $<0.0001$ & 196 & 279 \\
\hline S8 & Northeast Creek at SR 1100 near Genlee, NC & 1-period & $1989-2013$ & 63.3 & $<0.0001$ & 275 & 446 \\
\hline S9 & Morgan Creek near White Cross, NC & 1-period & 1989-2013 & 7.6 & 0.0483 & 107 & 115 \\
\hline \multirow[t]{2}{*}{$\mathrm{S} 10$} & Morgan Creek near Farrington, NC & 2-period & $1989-2001$ & 84.5 & $<0.0001$ & 180 & 324 \\
\hline & & & $2002-2013$ & 5.5 & 0.2666 & 328 & 346 \\
\hline $\mathrm{S} 11$ & White Oak Creek at mouth near Green Level, NC & Late period & $2002-2013$ & 25.1 & 0.0021 & 78 & 97 \\
\hline S12 & Haw River below B. Everett Jordan Dam near Moncure, NC & 1-period & 1989-2013 & 19.1 & 0.0006 & 140 & 166 \\
\hline $\mathrm{S} 13$ & $\begin{array}{l}\text { Cape Fear River at State Highway } 42 \text { near } \\
\text { Brickhaven, NC }\end{array}$ & 1-period & $1989-2012$ & 9.0 & 0.0143 & 138 & 150 \\
\hline L1 & Little River Reservoir at Dam near Bahama, NC & 1-period & 1989-2013 & 15.6 & $<0.0001$ & 65 & 76 \\
\hline L2 & Lake Michie at Dam near Bahama, NC & 1-period & 1989-2013 & 12.0 & 0.0006 & 63 & 71 \\
\hline L3 & Cane Creek Reservoir at Dam near White Cross, NC & none & 1989-2013 & \multicolumn{2}{|c|}{ model error } & & \\
\hline L4 & Jordan Lake, Haw River Arm near Hanks Chapel, NC & 1-period & $1991-2013$ & -7.2 & 0.0010 & 171 & 160 \\
\hline L5 & University Lake at Intakes near Chapel Hill, NC & 1-period & 1989-2013 & 23.8 & $<0.0001$ & 90 & 111 \\
\hline \multirow[t]{2}{*}{ L6 } & Jordan Lake at Buoy 12 at Farrington, NC & 2-period & $1993-2001$ & 25.5 & $<0.0001$ & 128 & 158 \\
\hline & & & $2002-2013$ & 5.8 & 0.0909 & 160 & 168 \\
\hline L7 & Jordan Lake above U.S. Highway 64 at Wilsonville, NC & 1-period & $1991-2013$ & 25.4 & $<0.0001$ & 131 & 163 \\
\hline L8 & $\begin{array}{l}\text { Jordan Lake at Bells Landing near Griffins } \\
\text { Crossroads, NC }\end{array}$ & 1-period & $1991-2013$ & 8.3 & 0.0177 & 144 & 156 \\
\hline \multicolumn{8}{|c|}{ Calcium, diss. (mg/L) } \\
\hline $\mathrm{S} 1$ & Eno River at Hillsborough, NC & 1-period & $1990-2013$ & 8.2 & 0.0170 & 6.84 & 7.40 \\
\hline S5 & Cane Creek near Orange Grove, $\mathrm{NC}$ & 1-period & 1989-2013 & 6.6 & 0.1371 & 7.03 & 7.48 \\
\hline S9 & Morgan Creek near White Cross, NC & 1-period & 1989-2013 & 20.0 & $<0.0001$ & 8.77 & 10.50 \\
\hline S11 & White Oak Creek at mouth near Green Level, NC & Late period & $2002-2013$ & 48.9 & $<0.0001$ & 4.60 & 6.75 \\
\hline $\mathrm{S} 13$ & $\begin{array}{l}\text { Cape Fear River at State Highway } 42 \text { near } \\
\text { Brickhaven, NC }\end{array}$ & Early period & $1989-2001$ & 5.4 & 0.0943 & 6.76 & 7.11 \\
\hline L1 & Little River Reservoir at Dam near Bahama, NC & 1-period & $1989-2013$ & 13.4 & $<0.0001$ & 5.30 & 6.00 \\
\hline $\mathrm{L} 2$ & Lake Michie at Dam near Bahama, NC & 1-period & $1989-2013$ & 4.5 & 0.0880 & 4.94 & 5.16 \\
\hline \multirow[t]{2}{*}{ L3 } & Cane Creek Reservoir at Dam nr White Cross, NC & 2-period & 1989-2001 & -12.9 & 0.0001 & 6.84 & 5.98 \\
\hline & & & $2002-2013$ & 12.7 & 0.0024 & 5.98 & 6.71 \\
\hline L4 & Jordan Lake, Haw River Arm near Hanks Chapel, NC & 1-period & $1991-2013$ & 14.6 & 0.0012 & 7.46 & 8.53 \\
\hline L5 & University Lake at Intakes near Chapel Hill, NC & 1-period & 1989-2013 & 26.5 & $<0.0001$ & 6.84 & 8.61 \\
\hline L6 & Jordan Lake at Buoy 12 at Farrington, NC & 1-period & $1993-2013$ & 20.6 & $<0.0001$ & 7.64 & 9.16 \\
\hline L7 & Jordan Lake above U.S. Highway 64 at Wilsonville, NC & 1-period & $1991-2013$ & 19.9 & $<0.0001$ & 6.82 & 8.15 \\
\hline L8 & $\begin{array}{l}\text { Jordan Lake at Bells Landing near Griffins } \\
\text { Crossroads, NC }\end{array}$ & 1-period & $1991-2013$ & 16.4 & $<0.0001$ & 6.68 & 7.76 \\
\hline \multicolumn{8}{|c|}{ Magnesium, diss. (mg/L) } \\
\hline $\mathrm{S} 1$ & Eno River at Hillsborough, NC & 1-period & $1990-2013$ & 8.7 & 0.0019 & 2.78 & 3.01 \\
\hline S5 & Cane Creek near Orange Grove, NC & 1-period & 1989-2013 & 7.8 & 0.0714 & 2.61 & 2.82 \\
\hline S9 & Morgan Creek near White Cross, NC & 1-period & $1989-2013$ & 10.1 & 0.0191 & 3.18 & 3.49 \\
\hline S11 & White Oak Creek at mouth near Green Level, NC & Late period & $2002-2013$ & 26.2 & $<0.0001$ & 1.95 & 2.44 \\
\hline $\mathrm{S} 13$ & $\begin{array}{l}\text { Cape Fear River at State Highway } 42 \text { near } \\
\text { Brickhaven, NC }\end{array}$ & Early period & 1989-2001 & 9.5 & 0.1976 & 2.64 & 2.87 \\
\hline
\end{tabular}


Table 8. Summary of trend results based on data collected during 1989-2013 for specific conductance, major ions, and nutrients at stream and lake sites assessed in the Triangle area of North Carolina.-Continued

[Bold red font indicates statistically significant (at p-value less than 0.05) upward trend results, and bold blue font indicates statistically significant downward trend results. Gray shading indicates no trend results are presented due to model error or because more than 20 percent of the data were censored. Abbreviations: USGS, U.S. Geological Survey; NC, North Carolina; $\mu \mathrm{S} / \mathrm{cm}$, microsiemens per centimeter; ${ }^{\circ} \mathrm{C}$, degree Celsius; <, less than; diss., dissolved; $\mathrm{mg} / \mathrm{L}$, milligram per liter; na, not applicable; $\mathrm{N}$, nitrogen; $\mathrm{P}$, phosphorus]

\begin{tabular}{|c|c|c|c|c|c|c|c|}
\hline $\begin{array}{l}\text { Map no. } \\
\text { (fig. 1) }\end{array}$ & USGS station name & Best-fit trend model & $\begin{array}{l}\text { Trend } \\
\text { period }\end{array}$ & $\begin{array}{l}\text { Percent } \\
\text { change }\end{array}$ & p-value & $\begin{array}{c}\text { Fitted annual } \\
\text { median } \\
\text { concentration for } \\
\text { first year } \\
\text { in period }\end{array}$ & $\begin{array}{c}\text { Fitted annual } \\
\text { median } \\
\text { concentration for } \\
\text { last year } \\
\text { in period }\end{array}$ \\
\hline \multicolumn{8}{|c|}{ Magnesium, diss. (mg/L)_Continued } \\
\hline L1 & Little River Reservoir at Dam near Bahama, NC & 1-period & $1989-2013$ & 14.2 & $<0.0001$ & 2.12 & 2.42 \\
\hline L2 & Lake Michie at Dam near Bahama, NC & 1-period & $1989-2013$ & 13.8 & $<0.0001$ & 2.05 & 2.33 \\
\hline \multirow[t]{2}{*}{ L3 } & Cane Creek Reservoir at Dam nr White Cross, NC & 2-period & $1989-2001$ & -5.0 & 0.0246 & 2.39 & 2.28 \\
\hline & & & $2002-2013$ & 2.8 & 0.2203 & 2.27 & 2.33 \\
\hline L4 & Jordan Lake, Haw River Arm near Hanks Chapel, NC & 1-period & $1991-2013$ & 17.5 & 0.0001 & 2.89 & 3.39 \\
\hline \multirow[t]{2}{*}{ L5 } & University Lake at Intakes near Chapel Hill, NC & 2-period & $1989-2001$ & 8.1 & 0.0063 & 2.54 & 2.74 \\
\hline & & & $2002-2013$ & 18.0 & $<0.0001$ & 2.75 & 3.21 \\
\hline L6 & Jordan Lake at Buoy 12 at Farrington, NC & 1-period & $1993-2013$ & 25.9 & $<0.0001$ & 2.52 & 3.16 \\
\hline L7 & Jordan Lake above U.S. Highway 64 at Wilsonville, NC & 1-period & $1991-2013$ & 18.0 & $<0.0001$ & 2.48 & 2.91 \\
\hline L8 & $\begin{array}{l}\text { Jordan Lake at Bells Landing near Griffins } \\
\text { Crossroads, NC }\end{array}$ & 1-period & $1991-2013$ & 13.1 & $<0.0001$ & 2.55 & 2.88 \\
\hline \multicolumn{8}{|c|}{ Potassium, diss. (mg/L) } \\
\hline $\mathrm{S} 1$ & Eno River at Hillsborough, $\mathrm{NC}$ & 1-period & $1990-2013$ & 13.5 & 0.0005 & 1.58 & 1.79 \\
\hline S5 & Cane Creek near Orange Grove, NC & 1-period & $1989-2013$ & -1.5 & na & 1.77 & 1.75 \\
\hline \multirow[t]{2}{*}{ S9 } & Morgan Creek near White Cross, NC & 2-period & $1989-2001$ & -20.7 & 0.0017 & 3.00 & 2.39 \\
\hline & & & $2002-2013$ & -6.9 & 0.2853 & 2.38 & 2.22 \\
\hline $\mathrm{S} 11$ & White Oak Creek at mouth near Green Level, NC & Late period & $2002-2013$ & 22.9 & $<0.0001$ & 2.89 & 3.52 \\
\hline $\mathrm{S} 13$ & $\begin{array}{l}\text { Cape Fear River at State Highway } 42 \text { near } \\
\text { Brickhaven, NC }\end{array}$ & Early period & $1989-2001$ & 18.0 & $<0.0001$ & 2.92 & 3.43 \\
\hline L1 & Little River Reservoir at Dam near Bahama, NC & 1-period & $1989-2013$ & 3.9 & 0.2506 & 1.88 & 1.95 \\
\hline \multirow[t]{2}{*}{$\mathrm{L} 2$} & Lake Michie at Dam near Bahama, NC & 2-period & $1989-2001$ & -6.3 & 0.0596 & 2.05 & 1.92 \\
\hline & & & $2002-2013$ & 16.8 & 0.0001 & 1.93 & 2.24 \\
\hline \multirow[t]{2}{*}{ L3 } & Cane Creek Reservoir at Dam nr White Cross, NC & 2-period & $1989-2001$ & -22.6 & $<0.0001$ & 2.84 & 2.23 \\
\hline & & & $2002-2013$ & 10.2 & $<0.0001$ & 2.22 & 2.44 \\
\hline L4 & Jordan Lake, Haw River Arm near Hanks Chapel, NC & 1-period & $1991-2013$ & 2.7 & na & 3.42 & 3.51 \\
\hline \multirow[t]{2}{*}{ L5 } & University Lake at Intakes near Chapel Hill, NC & 2-period & $1989-2001$ & -9.9 & 0.0055 & 2.68 & 2.42 \\
\hline & & & $2002-2013$ & 1.4 & 0.3681 & 2.42 & 2.45 \\
\hline L6 & Jordan Lake at Buoy 12 at Farrington, NC & 1-period & $1993-2013$ & 28.5 & $<0.0001$ & 3.18 & 4.06 \\
\hline L7 & Jordan Lake above U.S. Highway 64 at Wilsonville, NC & 1-period & $1991-2013$ & 22.5 & $<0.0001$ & 2.95 & 3.60 \\
\hline L8 & $\begin{array}{l}\text { Jordan Lake at Bells Landing near Griffins } \\
\text { Crossroads, NC }\end{array}$ & 1-period & $1991-2013$ & 13.0 & na & 3.04 & 3.43 \\
\hline \multicolumn{8}{|c|}{ Sodium, diss. (mg/L) } \\
\hline $\mathrm{S} 1$ & Eno River at Hillsborough, $\mathrm{NC}$ & 1-period & $1990-2013$ & 10.5 & 0.0173 & 5.13 & 5.66 \\
\hline S5 & Cane Creek near Orange Grove, NC & 1-period & $1989-2013$ & 5.1 & 0.1426 & 5.14 & 5.40 \\
\hline S9 & Morgan Creek near White Cross, NC & 1-period & $1989-2013$ & 30.0 & $<0.0001$ & 5.12 & 6.62 \\
\hline $\mathrm{S} 11$ & White Oak Creek at mouth near Green Level, NC & Late period & $2002-2013$ & 55.2 & $<0.0001$ & 5.21 & 7.93 \\
\hline $\mathrm{S} 13$ & $\begin{array}{l}\text { Cape Fear River at State Highway } 42 \text { near } \\
\text { Brickhaven, NC }\end{array}$ & Early period & $1989-2001$ & -0.4 & na & 14.09 & 14.06 \\
\hline L1 & Little River Reservoir at Dam near Bahama, NC & 1-period & $1989-2013$ & 27.9 & $<0.0001$ & 3.61 & 4.60 \\
\hline $\mathrm{L} 2$ & Lake Michie at Dam near Bahama, NC & 1-period & $1989-2013$ & 8.4 & 0.0773 & 4.11 & 4.45 \\
\hline \multirow[t]{2}{*}{ L3 } & Cane Creek Reservoir at Dam nr White Cross, NC & 2-period & $1989-2001$ & -5.1 & 0.1257 & 4.08 & 3.88 \\
\hline & & & $2002-2013$ & 16.3 & 0.0003 & 3.89 & 4.50 \\
\hline \multirow[t]{2}{*}{ L4 } & Jordan Lake, Haw River Arm near Hanks Chapel, NC & 2-period & $1991-2001$ & -23.4 & 0.0325 & 21.48 & 16.67 \\
\hline & & & $2002-2013$ & -4.5 & 0.3615 & 16.56 & 15.85 \\
\hline L5 & University Lake at Intakes near Chapel Hill, NC & 1-period & $1989-2013$ & 38.4 & $<0.0001$ & 5.19 & 7.13 \\
\hline \multirow[t]{2}{*}{ L6 } & Jordan Lake at Buoy 12 at Farrington, NC & 2-period & $1993-2001$ & 45.2 & $<0.0001$ & 11.35 & 16.14 \\
\hline & & & $2002-2013$ & 13.6 & 0.0246 & 16.37 & 18.49 \\
\hline L7 & Jordan Lake above U.S. Highway 64 at Wilsonville, NC & 1-period & $1991-2013$ & 33.0 & $<0.0001$ & 13.15 & 17.40 \\
\hline L8 & $\begin{array}{l}\text { Jordan Lake at Bells Landing near Griffins } \\
\text { Crossroads, NC }\end{array}$ & 1-period & $1991-2013$ & 8.1 & 0.3055 & 15.24 & 16.44 \\
\hline
\end{tabular}


Table 8. Summary of trend results based on data collected during 1989-2013 for specific conductance, major ions, and nutrients at stream and lake sites assessed in the Triangle area of North Carolina.-Continued

[Bold red font indicates statistically significant (at p-value less than 0.05) upward trend results, and bold blue font indicates statistically significant downward trend results. Gray shading indicates no trend results are presented due to model error or because more than 20 percent of the data were censored. Abbreviations: USGS, U.S. Geological Survey; NC, North Carolina; $\mu \mathrm{S} / \mathrm{cm}$, microsiemens per centimeter; ${ }^{\circ} \mathrm{C}$, degree Celsius; <, less than; diss., dissolved; $\mathrm{mg} / \mathrm{L}$, milligram per liter; na, not applicable; $\mathrm{N}$, nitrogen; $\mathrm{P}$, phosphorus]

\begin{tabular}{|c|c|c|c|c|c|c|c|}
\hline $\begin{array}{l}\text { Map no. } \\
\text { (fig. 1) }\end{array}$ & USGS station name & Best-fit trend model & $\begin{array}{l}\text { Trend } \\
\text { period }\end{array}$ & $\begin{array}{l}\text { Percent } \\
\text { change }\end{array}$ & p-value & $\begin{array}{c}\text { Fitted annual } \\
\text { median } \\
\text { concentration for } \\
\text { first year } \\
\text { in period } \\
\end{array}$ & $\begin{array}{c}\text { Fitted annual } \\
\text { median } \\
\text { concentration for } \\
\text { last year } \\
\text { in period } \\
\end{array}$ \\
\hline \multicolumn{8}{|c|}{ Chloride, diss. (mg/L) } \\
\hline S1 & Eno River at Hillsborough, NC & 1-period & 1990-2013 & 37.1 & $<0.0001$ & 5.05 & 6.89 \\
\hline S5 & Cane Creek near Orange Grove, $\mathrm{NC}$ & 1-period & 1989-2013 & 5.5 & 0.1023 & 6.31 & 6.65 \\
\hline \multirow[t]{2}{*}{ S9 } & Morgan Creek near White Cross, NC & 2-period & 1989-2001 & -2.1 & 0.3376 & 6.62 & 6.49 \\
\hline & & & 2002-2013 & 47.2 & $<0.0001$ & 6.54 & 9.47 \\
\hline S11 & White Oak Creek at mouth near Green Level, NC & Late period & $2002-2013$ & 48.9 & $<0.0001$ & 6.30 & 9.22 \\
\hline S13 & $\begin{array}{l}\text { Cape Fear River at State Highway } 42 \text { near } \\
\text { Brickhaven, NC }\end{array}$ & Early period & 1989-2001 & 15.4 & 0.0723 & 11.59 & 13.30 \\
\hline L1 & Little River Reservoir at Dam near Bahama, NC & 1-period & 1989-2013 & 32.4 & $<0.0001$ & 4.07 & 5.36 \\
\hline L2 & Lake Michie at Dam near Bahama, NC & 1-period & 1989-2013 & 6.0 & 0.1542 & 4.50 & 4.76 \\
\hline \multirow[t]{2}{*}{ L3 } & Cane Creek Reservoir at Dam nr White Cross, NC & 2-period & 1989-2001 & -5.0 & 0.1518 & 5.71 & 5.43 \\
\hline & & & $2002-2013$ & 15.0 & 0.0012 & 5.45 & 6.22 \\
\hline L4 & Jordan Lake, Haw River Arm near Hanks Chapel, NC & 1-period & 1991-2013 & 1.1 & na & 14.35 & 14.49 \\
\hline L5 & University Lake at Intakes near Chapel Hill, NC & 1-period & 1989-2013 & 42.2 & $<0.0001$ & 5.19 & 7.34 \\
\hline L6 & Jordan Lake at Buoy 12 at Farrington, $\mathrm{NC}$ & 1-period & 1993-2013 & 46.9 & $<0.0001$ & 13.27 & 19.28 \\
\hline L7 & Jordan Lake above U.S. Highway 64 at Wilsonville, NC & 1-period & 1991-2013 & 41.6 & $<0.0001$ & 11.68 & 16.41 \\
\hline \multirow[t]{2}{*}{ L8 } & Jordan Lake at Bells Landing near Griffins & 2-period & 1991-2001 & 23.6 & $<0.0001$ & 11.86 & 14.52 \\
\hline & Crossroads, $\mathrm{NC}$ & & 2002-2013 & 6.6 & 0.1942 & 14.60 & 15.52 \\
\hline \multicolumn{8}{|c|}{ Sulfate, diss. (mg/L) } \\
\hline S1 & Eno River at Hillsborough, NC & 1-period & 1990-2013 & -3.8 & 0.3771 & 5.32 & 5.12 \\
\hline S5 & Cane Creek near Orange Grove, $\mathrm{NC}$ & 1-period & 1989-2013 & 2.8 & 0.8875 & 3.45 & 3.55 \\
\hline \multirow[t]{2}{*}{ S9 } & Morgan Creek near White Cross, NC & 2-period & 1989-2001 & -19.5 & 0.0116 & 4.82 & 3.91 \\
\hline & & & 2002-2013 & 21.0 & 0.0529 & 3.91 & 4.70 \\
\hline S11 & White Oak Creek at mouth near Green Level, NC & Late period & 2002-2013 & -13.1 & 0.3078 & 6.37 & 5.57 \\
\hline S13 & $\begin{array}{l}\text { Cape Fear River at State Highway } 42 \text { near } \\
\text { Brickhaven, NC }\end{array}$ & Early period & 1989-2001 & -14.8 & 0.0010 & 14.72 & 12.65 \\
\hline \multirow[t]{2}{*}{ L1 } & Little River Reservoir at Dam near Bahama, NC & 2-period & 1989-2001 & -4.2 & 0.2701 & 4.74 & 4.55 \\
\hline & & & 2002-2013 & -21.8 & $<0.0001$ & 4.53 & 3.57 \\
\hline \multirow[t]{2}{*}{ L2 } & Lake Michie at Dam near Bahama, NC & 2-period & 1989-2001 & -3.3 & 0.3105 & 4.62 & 4.49 \\
\hline & & & 2002-2013 & -27.7 & $<0.0001$ & 4.45 & 3.26 \\
\hline \multirow[t]{2}{*}{ L3 } & Cane Creek Reservoir at Dam nr White Cross, NC & 2-period & 1989-2001 & -12.0 & 0.0055 & 3.75 & 3.32 \\
\hline & & & 2002-2013 & -20.7 & $<0.0001$ & 3.29 & 2.64 \\
\hline L4 & Jordan Lake, Haw River Arm near Hanks Chapel, NC & 1-period & $1991-2013$ & -42.9 & $<0.0001$ & 21.38 & 12.37 \\
\hline L5 & University Lake at Intakes near Chapel Hill, NC & 1-period & 1989-2013 & 27.4 & 0.0003 & 4.73 & 6.00 \\
\hline L6 & Jordan Lake at Buoy 12 at Farrington, $\mathrm{NC}$ & 1-period & 1993-2013 & 9.7 & 0.0094 & 13.49 & 14.76 \\
\hline \multirow[t]{2}{*}{ L7 } & Jordan Lake above U.S. Highway 64 at Wilsonville, NC & 2-period & 1991-2001 & -15.6 & 0.0001 & 15.28 & 13.00 \\
\hline & & & 2002-2013 & 5.1 & 0.1804 & 12.97 & 13.61 \\
\hline L8 & $\begin{array}{l}\text { Jordan Lake at Bells Landing near Griffins } \\
\text { Crossroads, NC }\end{array}$ & 1-period & $1991-2013$ & -26.4 & $<0.0001$ & 16.79 & 12.45 \\
\hline \multicolumn{8}{|c|}{ Nitrate + nitrite, diss. (mg/L as N) } \\
\hline S1 & Eno River at Hillsborough, NC & 1-period & 1990-2013 & -12.3 & 0.0561 & 0.255 & 0.224 \\
\hline S2 & Eno River near Durham, NC & 1-period & 1989-2013 & -47.3 & 0.0001 & 0.324 & 0.178 \\
\hline S3 & Little River at SR 1461 near Orange Factory, NC & 1-period & 1989-2013 & -18.2 & 0.0381 & 0.198 & 0.163 \\
\hline S4 & Flat River at Bahama, NC & 1-period & 1989-2011 & -24.5 & 0.2921 & 0.204 & 0.155 \\
\hline \multirow[t]{2}{*}{ S5 } & Cane Creek near Orange Grove, $\mathrm{NC}$ & 2-period & 1989-2001 & -29.0 & 0.0079 & 0.553 & 0.398 \\
\hline & & & 2002-2013 & 34.9 & 0.0194 & 0.398 & 0.530 \\
\hline S6 & Haw River near Bynum, NC & 1-period & 1989-2013 & -24.3 & 0.0001 & 1.096 & 0.834 \\
\hline \multirow[t]{2}{*}{ S7 } & New Hope Creek near Blands, NC & 2-period & 1989-2001 & -54.2 & $<0.0001$ & 4.350 & 2.056 \\
\hline & & & 2002-2013 & 30.9 & 0.0005 & 2.035 & 2.630 \\
\hline S8 & Northeast Creek at SR 1100 near Genlee, NC & Step, July 2005 & 1989-2013 & -75.5 & $<0.0001$ & 5.682 & 1.365 \\
\hline
\end{tabular}


Table 8. Summary of trend results based on data collected during 1989-2013 for specific conductance, major ions, and nutrients at stream and lake sites assessed in the Triangle area of North Carolina.-Continued

[Bold red font indicates statistically significant (at p-value less than 0.05) upward trend results, and bold blue font indicates statistically significant downward trend results. Gray shading indicates no trend results are presented due to model error or because more than 20 percent of the data were censored. Abbreviations: USGS, U.S. Geological Survey; NC, North Carolina; $\mu \mathrm{S} / \mathrm{cm}$, microsiemens per centimeter; ${ }^{\circ} \mathrm{C}$, degree Celsius; $<$, less than; diss., dissolved; $\mathrm{mg} / \mathrm{L}$, milligram per liter; na, not applicable; $\mathrm{N}$, nitrogen; $\mathrm{P}$, phosphorus]

\begin{tabular}{|c|c|c|c|c|c|c|c|}
\hline $\begin{array}{l}\text { Map no. } \\
\text { (fig. 1) }\end{array}$ & USGS station name & Best-fit trend model & $\begin{array}{l}\text { Trend } \\
\text { period }\end{array}$ & $\begin{array}{l}\text { Percent } \\
\text { change }\end{array}$ & p-value & $\begin{array}{c}\text { Fitted annual } \\
\text { median } \\
\text { concentration for } \\
\text { first year } \\
\text { in period }\end{array}$ & $\begin{array}{c}\text { Fitted annual } \\
\text { median } \\
\text { concentration for } \\
\text { last year } \\
\text { in period }\end{array}$ \\
\hline \multicolumn{8}{|c|}{ Nitrate + nitrite, diss. $(\mathrm{mg} / \mathrm{L}$ as N)—Continued } \\
\hline S9 & Morgan Creek near White Cross, NC & 1-period & 1989-2013 & -48.4 & 0.0116 & 0.500 & 0.262 \\
\hline \multirow[t]{2}{*}{$\mathrm{S} 10$} & Morgan Creek near Farrington, NC & 2-period & 1989-2001 & 41.3 & 0.0050 & 2.773 & 3.864 \\
\hline & & & $2002-2013$ & -31.3 & 0.0056 & 3.855 & 2.692 \\
\hline S11 & White Oak Creek at mouth near Green Level, NC & Late period & $2002-2013$ & 86.2 & 0.0001 & 0.034 & 0.062 \\
\hline $\mathrm{S} 12$ & Haw River below B. Everett Jordan Dam near Moncure, NC & Early period & $1989-2000$ & -37.2 & $<0.0001$ & 0.547 & 0.350 \\
\hline S13 & $\begin{array}{l}\text { Cape Fear River at State Highway } 42 \text { near } \\
\text { Brickhaven, NC }\end{array}$ & 1-period & 1989-2012 & -6.2 & 0.5967 & 0.431 & 0.405 \\
\hline L1 & Little River Reservoir at Dam near Bahama, NC & none & 1989-2013 & \multicolumn{2}{|c|}{ highly censored } & & \\
\hline $\mathrm{L} 2$ & Lake Michie at Dam near Bahama, NC & none & 1989-2013 & \multicolumn{2}{|c|}{ highly censored } & & \\
\hline L3 & Cane Creek Reservoir at Dam nr White Cross, NC & none & 1989-2013 & \multicolumn{2}{|c|}{ highly censored } & & \\
\hline \multirow[t]{2}{*}{ L4 } & Jordan Lake, Haw River Arm near Hanks Chapel, NC & 2-period & $1991-2001$ & 3.3 & 0.3951 & 0.306 & 0.316 \\
\hline & & & $2002-2013$ & -23.3 & $<0.0001$ & 0.314 & 0.244 \\
\hline L5 & University Lake at Intakes near Chapel Hill, NC & none & $1989-2013$ & \multicolumn{2}{|c|}{ highly censored } & & \\
\hline L6 & Jordan Lake at Buoy 12 at Farrington, NC & none & 1993-2013 & \multicolumn{2}{|c|}{ highly censored } & & \\
\hline L7 & Jordan Lake above U.S. Highway 64 at Wilsonville, NC & none & $1991-2013$ & \multicolumn{2}{|c|}{ highly censored } & & \\
\hline L8 & $\begin{array}{l}\text { Jordan Lake at Bells Landing near Griffins } \\
\text { Crossroads, NC }\end{array}$ & none & $1991-2013$ & \multicolumn{2}{|c|}{ highly censored } & & \\
\hline \multicolumn{8}{|c|}{ Ammonia, diss. (mg/L as N) } \\
\hline \multirow[t]{2}{*}{ S1 } & Eno River at Hillsborough, NC & 2-period & $1990-2001$ & -34.8 & $<0.0001$ & 0.042 & 0.028 \\
\hline & & & 2002-2013 & -0.2 & 0.3909 & 0.028 & 0.028 \\
\hline $\mathrm{S} 2$ & Eno River near Durham, NC & none & 1989-2013 & \multicolumn{2}{|c|}{ highly censored } & & \\
\hline $\mathrm{S} 3$ & Little River at SR 1461 near Orange Factory, NC & none & 1989-2013 & \multicolumn{2}{|c|}{ highly censored } & & \\
\hline S4 & Flat River at Bahama, NC & none & 1989-2011 & \multicolumn{2}{|c|}{ highly censored } & & \\
\hline S5 & Cane Creek near Orange Grove, NC & none & $1989-2013$ & \multicolumn{2}{|c|}{ highly censored } & & \\
\hline S6 & Haw River near Bynum, NC & none & 1989-2013 & \multicolumn{2}{|c|}{ highly censored } & & \\
\hline S7 & New Hope Creek near Blands, NC & 1-period & $1989-2013$ & -39.0 & 0.0043 & 0.063 & 0.039 \\
\hline S8 & Northeast Creek at SR 1100 near Genlee, NC & Step, July 2005 & 1989-2013 & $-\mathbf{5 7 . 3}$ & $<0.0001$ & 0.121 & 0.043 \\
\hline \multirow[t]{2}{*}{ S9 } & Morgan Creek near White Cross, NC & 2-period & 1989-2001 & -49.9 & 0.0001 & 0.056 & 0.029 \\
\hline & & & $2002-2013$ & -20.1 & 0.2083 & 0.028 & 0.023 \\
\hline \multirow[t]{2}{*}{ S10 } & Morgan Creek near Farrington, NC & 2-period & 1989-2001 & 9.3 & 0.3490 & 0.088 & 0.096 \\
\hline & & & $2002-2013$ & -50.0 & 0.0004 & 0.095 & 0.049 \\
\hline S 11 & White Oak Creek at mouth near Green Level, NC & Late period & $2002-2013$ & 27.6 & na & 0.019 & 0.024 \\
\hline S12 & Haw River below B. Everett Jordan Dam near Moncure, NC & Early period & $1989-2000$ & -54.4 & 0.0001 & 0.139 & 0.066 \\
\hline \multirow[t]{2}{*}{$\mathrm{S} 13$} & Cape Fear River at State Highway 42 near & 2-period & $1989-2001$ & -29.2 & 0.0001 & 0.091 & 0.065 \\
\hline & Brickhaven, NC & & $2002-2012$ & -2.6 & 0.3840 & 0.065 & 0.063 \\
\hline \multirow[t]{2}{*}{$\mathrm{L} 1$} & Little River Reservoir at Dam near Bahama, NC & 2-period & $1989-2001$ & -73.4 & $<0.0001$ & 0.117 & 0.033 \\
\hline & & & $2002-2013$ & -25.2 & 0.1647 & 0.032 & 0.024 \\
\hline \multirow[t]{2}{*}{ L2 } & Lake Michie at Dam near Bahama, NC & 2-period & $1989-2001$ & -80.9 & $<0.0001$ & 0.117 & 0.024 \\
\hline & & & $2002-2013$ & 125.4 & 0.0001 & 0.023 & 0.051 \\
\hline L3 & Cane Creek Reservoir at Dam nr White Cross, NC & 2-period & 1989-2001 & -69.0 & $<0.0001$ & 0.129 & 0.042 \\
\hline & & & $2002-2013$ & 87.5 & 0.0277 & 0.041 & 0.076 \\
\hline L4 & Jordan Lake, Haw River Arm near Hanks Chapel, NC & 1-period & $1991-2013$ & -17.7 & 0.2059 & 0.040 & 0.033 \\
\hline L5 & University Lake at Intakes near Chapel Hill, NC & none & $1989-2013$ & higl & censored & & \\
\hline L6 & Jordan Lake at Buoy 12 at Farrington, NC & none & 1993-2013 & higl & censored & & \\
\hline L7 & Jordan Lake above U.S. Highway 64 at Wilsonville, NC & none & $1991-2013$ & higl & censored & & \\
\hline L8 & $\begin{array}{l}\text { Jordan Lake at Bells Landing near Griffins } \\
\text { Crossroads, NC }\end{array}$ & none & $1991-2013$ & higl & censored & & \\
\hline
\end{tabular}


Table 8. Summary of trend results based on data collected during 1989-2013 for specific conductance, major ions, and nutrients at stream and lake sites assessed in the Triangle area of North Carolina.-Continued

[Bold red font indicates statistically significant (at p-value less than 0.05) upward trend results, and bold blue font indicates statistically significant downward trend results. Gray shading indicates no trend results are presented due to model error or because more than 20 percent of the data were censored. Abbreviations: USGS, U.S. Geological Survey; NC, North Carolina; $\mu \mathrm{S} / \mathrm{cm}$, microsiemens per centimeter; ${ }^{\circ} \mathrm{C}$, degree Celsius; <, less than; diss., dissolved; $\mathrm{mg} / \mathrm{L}$, milligram per liter; na, not applicable; $\mathrm{N}$, nitrogen; $\mathrm{P}$, phosphorus]

\begin{tabular}{|c|c|c|c|c|c|c|c|}
\hline $\begin{array}{l}\text { Map no. } \\
\text { (fig. 1) }\end{array}$ & USGS station name & Best-fit trend model & $\begin{array}{l}\text { Trend } \\
\text { period }\end{array}$ & $\begin{array}{l}\text { Percent } \\
\text { change }\end{array}$ & p-value & $\begin{array}{l}\text { Fitted annual } \\
\text { median } \\
\text { concentration for } \\
\text { first year } \\
\text { in period }\end{array}$ & $\begin{array}{c}\text { Fitted annual } \\
\text { median } \\
\text { concentration for } \\
\text { last year } \\
\text { in period }\end{array}$ \\
\hline \multicolumn{8}{|c|}{ Total organic N (mg/L as N) } \\
\hline $\mathrm{S} 1$ & Eno River at Hillsborough, $\mathrm{NC}$ & 1-period & $1990-2013$ & 29.1 & 0.0005 & 0.29 & 0.37 \\
\hline $\mathrm{S} 2$ & Eno River near Durham, NC & 1-period & 1989-2013 & 20.1 & 0.0099 & 0.26 & 0.31 \\
\hline S3 & Little River at SR 1461 near Orange Factory, NC & 1-period & 1989-2013 & 48.3 & $<0.0001$ & 0.25 & 0.36 \\
\hline S4 & Flat River at Bahama, $\mathrm{NC}$ & 1-period & 1989-2011 & 29.4 & 0.0015 & 0.26 & 0.34 \\
\hline \multirow[t]{2}{*}{ S5 } & Cane Creek near Orange Grove, NC & 2-period & $1989-2001$ & -19.3 & 0.0748 & 0.37 & 0.30 \\
\hline & & & $2002-2013$ & 60.7 & 0.0001 & 0.30 & 0.48 \\
\hline S6 & Haw River near Bynum, NC & 1-period & 1989-2013 & 44.9 & $<0.0001$ & 0.39 & 0.56 \\
\hline S7 & New Hope Creek near Blands, NC & 1-period & $1989-2013$ & 75.0 & $<0.0001$ & 0.48 & 0.83 \\
\hline S8 & Northeast Creek at SR 1100 near Genlee, NC & 1-period & $1989-2013$ & 43.9 & na & 0.61 & 0.87 \\
\hline \multirow[t]{2}{*}{ S9 } & Morgan Creek near White Cross, NC & 2-period & 1989-2001 & -27.2 & 0.0065 & 0.43 & 0.32 \\
\hline & & & $2002-2013$ & -13.4 & 0.2131 & 0.31 & 0.27 \\
\hline S10 & Morgan Creek near Farrington, NC & 1-period & $1989-2013$ & 46.9 & $<0.0001$ & 0.48 & 0.70 \\
\hline S11 & White Oak Creek at mouth near Green Level, NC & Late period & $2002-2013$ & 6.1 & 0.2987 & 0.56 & 0.60 \\
\hline $\mathrm{S} 12$ & Haw River below B. Everett Jordan Dam near Moncure, NC & Early period & $1989-2000$ & -11.0 & 0.2401 & 0.45 & 0.40 \\
\hline $\mathrm{S} 13$ & $\begin{array}{l}\text { Cape Fear River at State Highway } 42 \text { near } \\
\text { Brickhaven, NC }\end{array}$ & 1-period & $1989-2012$ & 30.6 & 0.0001 & 0.51 & 0.66 \\
\hline L1 & Little River Reservoir at Dam near Bahama, NC & 1-period & $1989-2013$ & 17.7 & $<0.0001$ & 0.40 & 0.46 \\
\hline $\mathrm{L} 2$ & Lake Michie at Dam near Bahama, NC & 1-period & 1989-2013 & 26.5 & $<0.0001$ & 0.53 & 0.67 \\
\hline \multirow[t]{2}{*}{ L3 } & Cane Creek Reservoir at Dam nr White Cross, NC & 2-period & $1989-2001$ & -10.6 & 0.0878 & 0.42 & 0.37 \\
\hline & & & $2002-2013$ & 31.5 & $<0.0001$ & 0.38 & 0.49 \\
\hline L4 & Jordan Lake, Haw River Arm near Hanks Chapel, NC & 1-period & $1991-2013$ & 8.2 & 0.5541 & 0.65 & 0.71 \\
\hline L5 & University Lake at Intakes near Chapel Hill, NC & 1-period & $1989-2013$ & 18.4 & $<0.0001$ & 0.53 & 0.63 \\
\hline \multirow[t]{2}{*}{ L6 } & Jordan Lake at Buoy 12 at Farrington, NC & 2-period & $1993-2001$ & 50.3 & $<0.0001$ & 0.68 & 0.99 \\
\hline & & & $2002-2013$ & -17.6 & 0.0147 & 1.00 & 0.83 \\
\hline \multirow[t]{2}{*}{ L7 } & Jordan Lake above U.S. Highway 64 at Wilsonville, NC & 2-period & $1991-2001$ & 34.9 & $<0.0001$ & 0.55 & 0.74 \\
\hline & & & $2002-2013$ & -8.8 & 0.0355 & 0.74 & 0.68 \\
\hline L8 & $\begin{array}{l}\text { Jordan Lake at Bells Landing near Griffins } \\
\text { Crossroads, NC }\end{array}$ & 1-period & $1991-2013$ & -3.5 & 0.5376 & 0.67 & 0.64 \\
\hline \multicolumn{8}{|c|}{ Total $\mathrm{N}$ (mg/L as N) } \\
\hline $\mathrm{S} 1$ & Eno River at Hillsborough, NC & 1-period & 1990-2013 & 8.8 & 0.1229 & 0.60 & 0.65 \\
\hline $\mathrm{S} 2$ & Eno River near Durham, NC & 1-period & $1989-2013$ & -17.6 & 0.0062 & 0.71 & 0.59 \\
\hline S3 & Little River at SR 1461 near Orange Factory, NC & 1-period & $1989-2013$ & 10.7 & 0.1750 & 0.52 & 0.58 \\
\hline S4 & Flat River at Bahama, NC & 1-period & 1989-2011 & -0.7 & 0.8065 & 0.55 & 0.55 \\
\hline \multirow[t]{2}{*}{ S5 } & Cane Creek near Orange Grove, $\mathrm{NC}$ & 2-period & 1989-2001 & -33.0 & $<0.0001$ & 1.12 & 0.76 \\
\hline & & & $2002-2013$ & 62.6 & $<0.0001$ & 0.77 & 1.22 \\
\hline S6 & Haw River near Bynum, NC & 1-period & $1989-2013$ & -6.5 & 0.1692 & 1.62 & 1.51 \\
\hline \multirow[t]{2}{*}{ S7 } & New Hope Creek near Blands, NC & 2-period & $1989-2001$ & -43.9 & $<0.0001$ & 5.12 & 2.94 \\
\hline & & & $2002-2013$ & 35.5 & $<0.0001$ & 2.92 & 3.91 \\
\hline S8 & Northeast Creek at SR 1100 near Genlee, NC & Step, July 2005 & 1989-2013 & -61.0 & $<0.0001$ & 6.73 & 2.54 \\
\hline \multirow[t]{2}{*}{ S9 } & Morgan Creek near White Cross, NC & 2-period & $1989-2001$ & -37.0 & $<0.0001$ & 1.27 & 0.81 \\
\hline & & & $2002-2013$ & -32.5 & 0.0001 & 0.80 & 0.55 \\
\hline \multirow[t]{2}{*}{ S10 } & Morgan Creek near Farrington, NC & 2-period & 1989-2001 & 41.6 & 0.0003 & 3.45 & 4.82 \\
\hline & & & $2002-2013$ & -26.0 & 0.0053 & 4.82 & 3.61 \\
\hline $\mathrm{S} 11$ & White Oak Creek at mouth near Green Level, NC & Late period & $2002-2013$ & 12.0 & 0.0093 & 0.62 & 0.69 \\
\hline $\mathrm{S} 12$ & Haw River below B. Everett Jordan Dam near Moncure, NC & Early period & $1989-2000$ & -29.9 & $<0.0001$ & 1.27 & 0.91 \\
\hline \multirow[t]{2}{*}{$\mathrm{S} 13$} & Cape Fear River at State Highway 42 near & 2-period & 1989-2001 & -13.8 & 0.0071 & 1.24 & 1.07 \\
\hline & Brickhaven, $\mathrm{NC}$ & & $2002-2012$ & 24.9 & 0.0003 & 1.08 & 1.33 \\
\hline L1 & Little River Reservoir at Dam near Bahama, NC & 1-period & $1989-2013$ & -13.5 & 0.0009 & 0.72 & 0.63 \\
\hline
\end{tabular}


Table 8. Summary of trend results based on data collected during 1989-2013 for specific conductance, major ions, and nutrients at stream and lake sites assessed in the Triangle area of North Carolina.-Continued

[Bold red font indicates statistically significant (at p-value less than 0.05) upward trend results, and bold blue font indicates statistically significant downward trend results. Gray shading indicates no trend results are presented due to model error or because more than 20 percent of the data were censored. Abbreviations: USGS, U.S. Geological Survey; NC, North Carolina; $\mu \mathrm{S} / \mathrm{cm}$, microsiemens per centimeter; ${ }^{\circ} \mathrm{C}$, degree Celsius; $<$, less than; diss., dissolved; $\mathrm{mg} / \mathrm{L}$, milligram per liter; na, not applicable; $\mathrm{N}$, nitrogen; $\mathrm{P}$, phosphorus]

\begin{tabular}{|c|c|c|c|c|c|c|c|}
\hline $\begin{array}{l}\text { Map no. } \\
\text { (fig. 1) }\end{array}$ & USGS station name & Best-fit trend model & $\begin{array}{l}\text { Trend } \\
\text { period }\end{array}$ & $\begin{array}{l}\text { Percent } \\
\text { change }\end{array}$ & p-value & $\begin{array}{l}\text { Fitted annual } \\
\text { median } \\
\text { concentration for } \\
\text { first year } \\
\text { in period }\end{array}$ & $\begin{array}{c}\text { Fitted annual } \\
\text { median } \\
\text { concentration for } \\
\text { last year } \\
\text { in period }\end{array}$ \\
\hline \multicolumn{8}{|c|}{ Total $\mathrm{N}(\mathrm{mg} / \mathrm{L}$ as $\mathrm{N})$-Continued } \\
\hline \multirow[t]{2}{*}{ L2 } & Lake Michie at Dam near Bahama, NC & 2-period & 1989-2001 & -13.2 & 0.0063 & 0.84 & 0.73 \\
\hline & & & $2002-2013$ & 16.9 & 0.0086 & 0.73 & 0.85 \\
\hline \multirow[t]{2}{*}{ L3 } & Cane Creek Reservoir at Dam nr White Cross, NC & 2-period & 1989-2001 & -33.8 & $<0.0001$ & 1.09 & 0.73 \\
\hline & & & $2002-2013$ & 31.2 & 0.0010 & 0.73 & 0.95 \\
\hline L4 & Jordan Lake, Haw River Arm near Hanks Chapel, NC & 1-period & $1991-2013$ & 2.5 & 0.8415 & 1.14 & 1.17 \\
\hline L5 & University Lake at Intakes near Chapel Hill, NC & 1-period & 1989-2013 & 2.9 & $<0.0001$ & 0.70 & 0.71 \\
\hline \multirow[t]{2}{*}{ L6 } & Jordan Lake at Buoy 12 at Farrington, $\mathrm{NC}$ & 2-period & $1993-2001$ & 21.4 & 0.0075 & 0.91 & 1.09 \\
\hline & & & $2002-2013$ & -8.5 & 0.1804 & 1.09 & 1.00 \\
\hline \multirow[t]{2}{*}{ L7 } & Jordan Lake above U.S. Highway 64 at Wilsonville, NC & 2-period & $1991-2001$ & 25.9 & $<0.0001$ & 0.71 & 0.89 \\
\hline & & & $2002-2013$ & -13.0 & 0.0046 & 0.89 & 0.78 \\
\hline L8 & $\begin{array}{l}\text { Jordan Lake at Bells Landing near Griffins } \\
\text { Crossroads, NC }\end{array}$ & 1-period & $1991-2013$ & -3.3 & 0.5716 & 0.84 & 0.81 \\
\hline \multicolumn{8}{|c|}{ Total $\mathrm{P}$ (mg/L as $\mathrm{P}$ ) } \\
\hline S1 & Eno River at Hillsborough, $\mathrm{NC}$ & 1-period & $1990-2013$ & -11.0 & 0.4624 & 0.039 & 0.035 \\
\hline S2 & Eno River near Durham, $\mathrm{NC}$ & 1-period & 1989-2013 & -25.9 & 0.0043 & 0.048 & 0.036 \\
\hline S3 & Little River at SR 1461 near Orange Factory, NC & 1-period & $1989-2013$ & 15.1 & 0.1371 & 0.033 & 0.038 \\
\hline S4 & Flat River at Bahama, NC & 1-period & 1989-2011 & -21.1 & $<0.0001$ & 0.048 & 0.038 \\
\hline \multirow[t]{2}{*}{ S5 } & Cane Creek near Orange Grove, $\mathrm{NC}$ & 2-period & $1989-2001$ & -34.4 & 0.0053 & 0.078 & 0.052 \\
\hline & & & $2002-2013$ & 42.2 & 0.0224 & 0.052 & 0.073 \\
\hline \multirow[t]{2}{*}{ S6 } & Haw River near Bynum, $\mathrm{NC}$ & 2-period & 1989-2001 & -20.5 & 0.0116 & 0.217 & 0.174 \\
\hline & & & $2002-2013$ & -44.4 & $<0.0001$ & 0.171 & 0.097 \\
\hline \multirow[t]{2}{*}{ S7 } & New Hope Creek near Blands, NC & 2-period & 1989-2001 & -44.8 & $<0.0001$ & 0.397 & 0.225 \\
\hline & & & $2002-2013$ & 2.2 & 0.3930 & 0.222 & 0.227 \\
\hline S8 & Northeast Creek at SR 1100 near Genlee, NC & 1-period & $1989-2013$ & -41.0 & 0.0007 & 0.388 & 0.232 \\
\hline \multirow[t]{2}{*}{ S9 } & Morgan Creek near White Cross, NC & 2-period & 1989-2001 & -63.6 & $<0.0001$ & 0.234 & 0.089 \\
\hline & & & 2002-2013 & -56.7 & $<0.0001$ & 0.085 & 0.038 \\
\hline S10 & Morgan Creek near Farrington, NC & 1-period & 1989-2013 & -6.9 & 0.3865 & 0.164 & 0.153 \\
\hline S11 & White Oak Creek at mouth near Green Level, $\mathrm{NC}$ & Late period & 2002-2013 & 53.5 & $<0.0001$ & 0.045 & 0.068 \\
\hline S12 & Haw River below B. Everett Jordan Dam near Moncure, NC & Early period & 1989-2000 & -41.8 & $<0.0001$ & 0.126 & 0.075 \\
\hline \multirow[t]{2}{*}{ S13 } & Cape Fear River at State Highway 42 near & 2-period & $1989-2001$ & 20.3 & 0.0431 & 0.108 & 0.129 \\
\hline & Brickhaven, $\mathrm{NC}$ & & 2002-2012 & -20.5 & 0.0347 & 0.129 & 0.104 \\
\hline L1 & Little River Reservoir at Dam near Bahama, NC & 1-period & 1989-2013 & -2.2 & 0.4028 & 0.037 & 0.036 \\
\hline \multirow[t]{2}{*}{ L2 } & Lake Michie at Dam near Bahama, $\mathrm{NC}$ & 2-period & 1989-2001 & -17.6 & 0.0007 & 0.041 & 0.034 \\
\hline & & & $2002-2013$ & 25.4 & 0.0006 & 0.034 & 0.043 \\
\hline L3 & Cane Creek Reservoir at Dam nr White Cross, NC & 1-period & $1989-2013$ & -8.1 & na & 0.033 & 0.030 \\
\hline L4 & Jordan Lake, Haw River arm near Hanks Chapel, NC & 1-period & 1991-2013 & 48.6 & 0.0008 & 0.064 & 0.094 \\
\hline L5 & University Lake at Intakes near Chapel Hill, NC & 1-period & 1989-2013 & 10.6 & 0.3833 & 0.035 & 0.039 \\
\hline L6 & Jordan Lake at Buoy 12 at Farrington, $\mathrm{NC}$ & 1-period & 1993-2013 & 57.8 & na & 0.055 & 0.086 \\
\hline \multirow[t]{2}{*}{ L7 } & Jordan Lake above U.S. Highway 64 at Wilsonville, NC & 2-period & 1991-2001 & 36.1 & $<0.0001$ & 0.033 & 0.044 \\
\hline & & & 2002-2013 & -10.2 & 0.0404 & 0.044 & 0.040 \\
\hline L8 & Jordan Lake at Bells Landing near Griffins & 1-period & $1991-2013$ & 15.3 & 0.0039 & 0.035 & 0.040 \\
\hline
\end{tabular}


Table 8. Summary of trend results based on data collected during 1989-2013 for specific conductance, major ions, and nutrients at stream and lake sites assessed in the Triangle area of North Carolina._-Continued

[Bold red font indicates statistically significant (at p-value less than 0.05) upward trend results, and bold blue font indicates statistically significant downward trend results. Gray shading indicates no trend results are presented due to model error or because more than 20 percent of the data were censored. Abbreviations: USGS, U.S. Geological Survey; NC, North Carolina; $\mu \mathrm{S} / \mathrm{cm}$, microsiemens per centimeter; ${ }^{\circ} \mathrm{C}$, degree Celsius; <, less than; diss., dissolved; $\mathrm{mg} / \mathrm{L}$, milligram per liter; na, not applicable; N, nitrogen; $\mathrm{P}$, phosphorus]

\begin{tabular}{|c|c|c|c|c|c|c|c|}
\hline $\begin{array}{l}\text { Map no. } \\
\text { (fig. 1) }\end{array}$ & USGS station name & Best-fit trend model & $\begin{array}{l}\text { Trend } \\
\text { period }\end{array}$ & $\begin{array}{l}\text { Percent } \\
\text { change }\end{array}$ & p-value & $\begin{array}{c}\text { Fitted annual } \\
\text { median } \\
\text { concentration for } \\
\text { first year } \\
\text { in period } \\
\end{array}$ & $\begin{array}{c}\text { Fitted annual } \\
\text { median } \\
\text { concentration for } \\
\text { last year } \\
\text { in period }\end{array}$ \\
\hline \multicolumn{8}{|c|}{ Total organic carbon (mg/L) } \\
\hline $\mathrm{S} 1$ & Eno River at Hillsborough, NC & 1-period & $1990-2013$ & 19.8 & 0.0015 & 5.2 & 6.2 \\
\hline S5 & Cane Creek near Orange Grove, NC & 1-period & 1989-2013 & 16.6 & 0.1846 & 5.5 & 6.3 \\
\hline \multirow[t]{2}{*}{ S9 } & Morgan Creek near White Cross, NC & 2-period & 1989-2001 & 0.5 & 0.3980 & 5.5 & 5.5 \\
\hline & & & $2002-2013$ & -21.1 & 0.0147 & 5.5 & 4.4 \\
\hline $\mathrm{S} 11$ & White Oak Creek at mouth near Green Level, NC & Late period & $2002-2013$ & -2.6 & 0.4386 & 11.4 & 11.1 \\
\hline $\mathrm{S} 13$ & $\begin{array}{l}\text { Cape Fear River at State Highway } 42 \text { near } \\
\text { Brickhaven, NC }\end{array}$ & Early period & $1989-2001$ & 6.1 & 0.6315 & 8.2 & 8.6 \\
\hline L1 & Little River Reservoir at Dam near Bahama, NC & 1-period & $1989-2013$ & 10.8 & na & 7.1 & 7.8 \\
\hline $\mathrm{L} 2$ & Lake Michie at Dam near Bahama, NC & 1-period & $1989-2013$ & 14.4 & 0.0183 & 8.4 & 9.6 \\
\hline L3 & Cane Creek Reservoir at Dam nr White Cross, NC & 1-period & 1989-2013 & 14.4 & 0.1670 & 7.1 & 8.1 \\
\hline \multirow[t]{2}{*}{ L4 } & Jordan Lake, Haw River arm near Hanks Chapel, NC & 2-period & $1991-2001$ & 6.0 & 0.2227 & 8.4 & 8.9 \\
\hline & & & $2002-2013$ & -12.3 & 0.0151 & 8.9 & 7.8 \\
\hline L5 & University Lake at Intakes near Chapel Hill, NC & 1-period & 1989-2013 & 18.2 & 0.0149 & 7.4 & 8.7 \\
\hline \multirow[t]{2}{*}{ L6 } & Jordan Lake at Buoy 12 at Farrington, NC & 2-period & $1993-2001$ & 12.6 & 0.0086 & 10.0 & 11.2 \\
\hline & & & $2002-2013$ & -8.2 & 0.1145 & 11.2 & 10.4 \\
\hline L7 & Jordan Lake above U.S. Highway 64 at Wilsonville, NC & 1-period & $1991-2013$ & 3.7 & 0.3833 & 8.6 & 9.0 \\
\hline \multirow[t]{2}{*}{ L8 } & Jordan Lake at Bells Landing near Griffins & 2-period & $1991-2001$ & 5.7 & 0.1394 & 8.3 & 8.7 \\
\hline & Crossroads, $\mathrm{NC}$ & & $2002-2013$ & -9.5 & 0.0264 & 8.7 & 7.9 \\
\hline
\end{tabular}



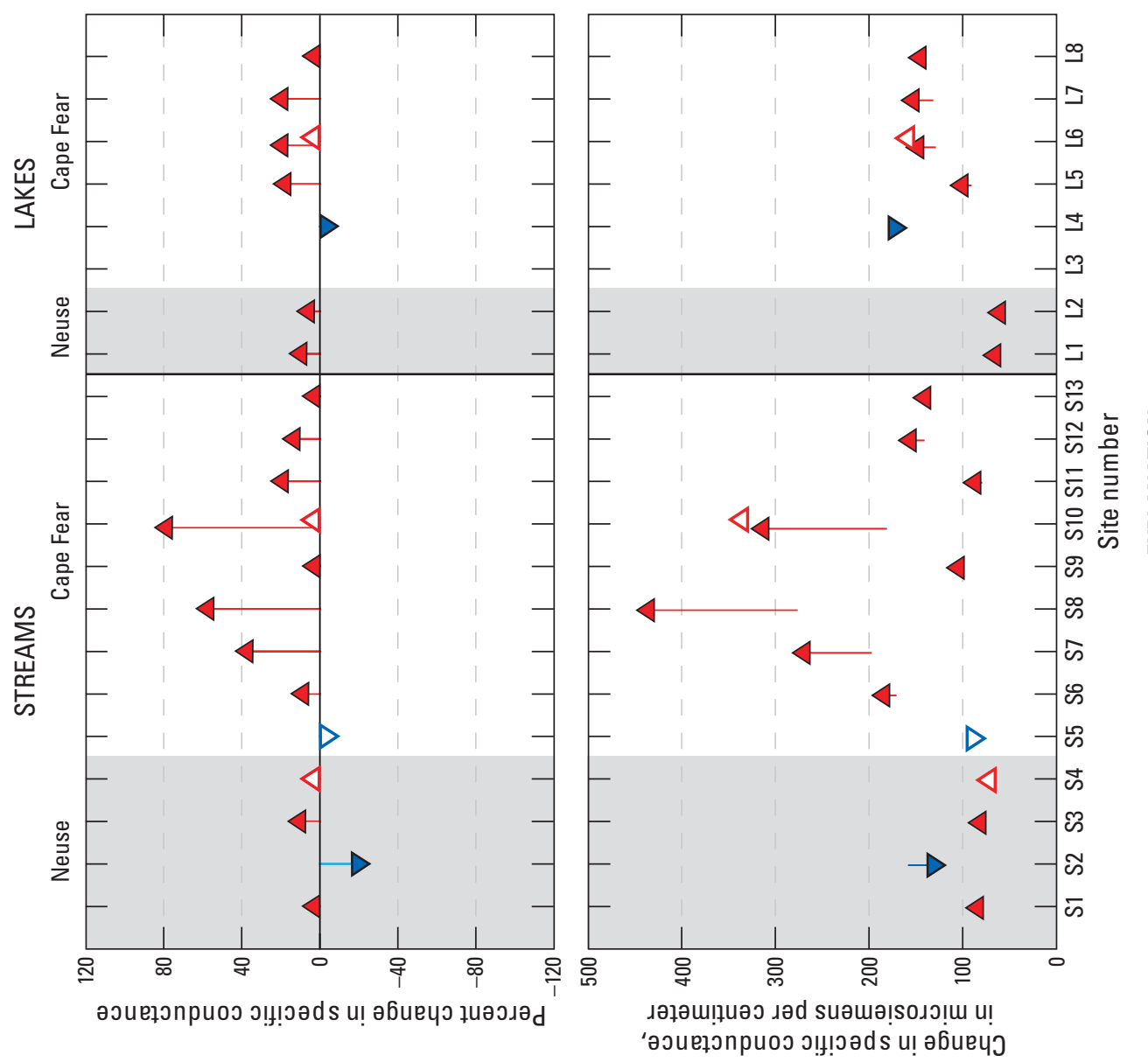

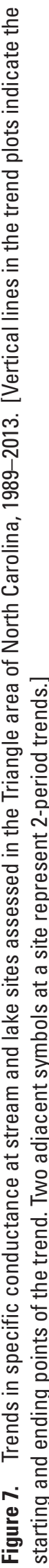

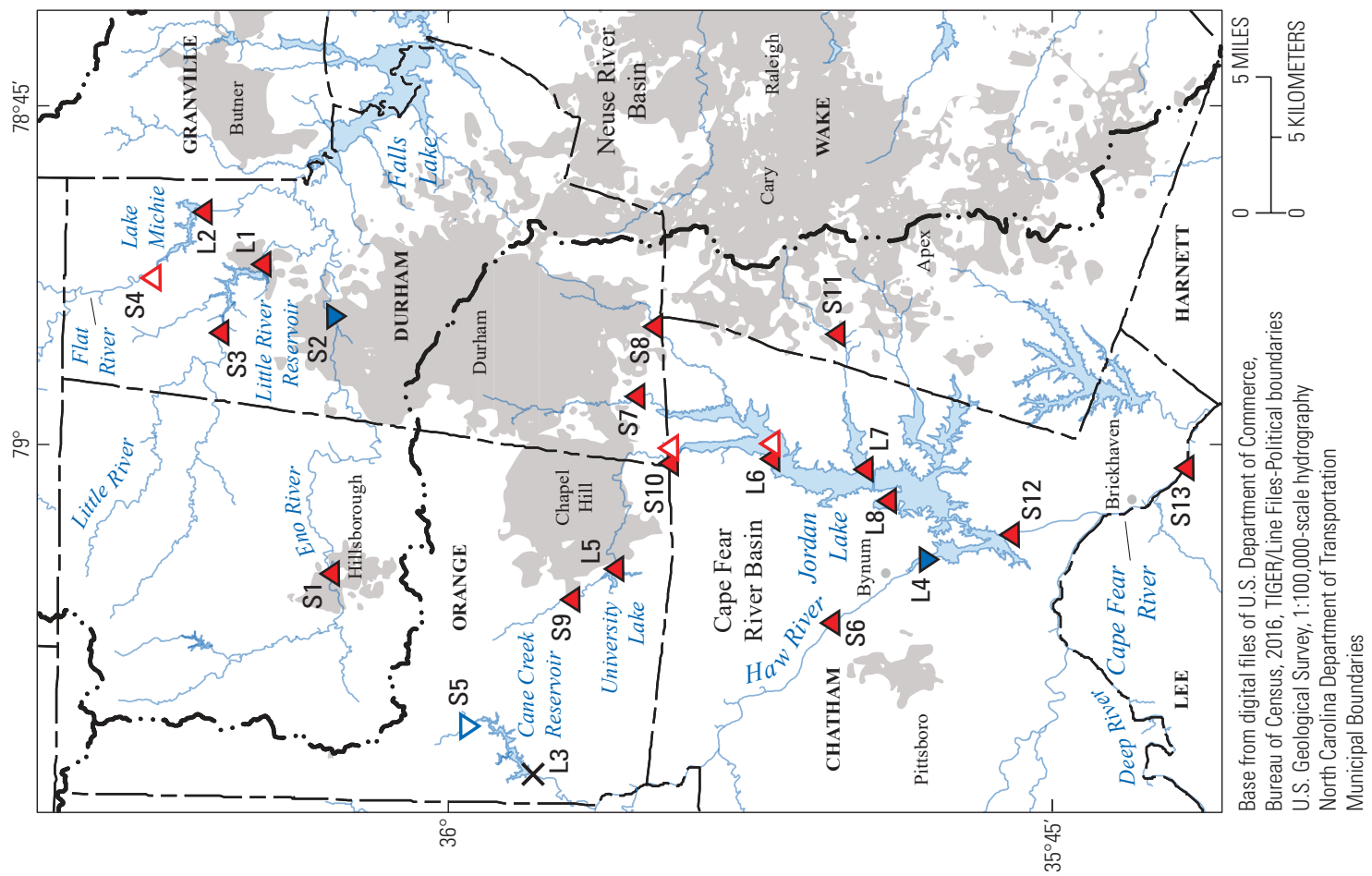


patterns observed for these major ions were remarkably similar throughout the study area.

Calcium trends ranged from a 12.9 percent decrease to a 48.9 percent increase during the various trend periods (table 8; fig. 8). A 1-period trend model provided the best fit for calcium data at 10 sites. During the 1-period trend period (1989-2013), calcium significantly increased at eight sites and showed smaller, nonsignificant uptrends at two additional sites. Calcium decreased significantly at Cane Creek Reservoir (site L3) during 1989-2001, but this downtrend was offset by a significant uptrend during 2002-13. At White Oak Creek (site S11), calcium increased significantly during 2002-13 and increased by a smaller, nonsignificant amount at Cape Fear River near Brickhaven (site S13) during 1989-2001.

Magnesium trends ranged from -5.0 to 26.2 percent (table 8; fig. 9). Similar to calcium, magnesium increased significantly during 1989-2013 at nine sites and to a lesser, nonsignificant degree at one site. Magnesium decreased significantly at Cane Creek Reservoir (site L3) during 1989-2001, but this decrease was more or less offset by a nonsignificant uptrend during 2002-13. Magnesium increased significantly at White Oak Creek (site S11) during 2002-13 and by a smaller, nonsignificant amount at Cape Fear River near Brickhaven (site S13) during 1989-2001.

Potassium trends were generally similar to calcium and magnesium trends, with notable exceptions at sites S9 and L5. Overall, trends ranged from -22.6 to 28.5 percent (table 8; fig. 10). During 1989-2013, potassium increased significantly at three sites and showed nonsignificant uptrends at three sites and a nonsignificant downtrend at one site. A 2-period trend model best fit the potassium concentrations at four sites. Significant potassium downtrends were noted for Morgan Creek near White Cross (site S9) and University Lake (site L5) during 1989-2001 followed by small, nonsignificant trends during 2002-13 compared to consistent uptrends for calcium and magnesium for those sites. Potassium decreased slightly at Lake Michie (site L2) during 1989-2001, then increased significantly during 2002-13. Potassium also increased significantly at White Oak Creek (site S11) during 2002-13 and increased at Cape Fear River near Brickhaven (site S13) during 1989-2001.

Sodium trends also were generally similar to calcium and magnesium trends at all sites except site L4. Trends ranged from -23.4 to 55.2 percent (table 8; fig. 11), with uptrends at most sites. Sodium increased significantly during 1989-2013 at five sites and to a lesser, nonsignificant degree at three sites. Significant uptrends also were observed at White Oak Creek (site S11) and Cane Creek Reservoir (site L3) during 2002-13. Sodium increased significantly at Jordan Lake at Buoy 12 (site L6) during both the early and late periods, although the rate of increase was substantially higher during the early period. For Jordan Lake near Hanks Chapel (site L4), a significant downtrend (23.4 percent) in sodium was observed during 1991-2001 and a small, nonsignificant downtrend was observed during 2002-13.
Chloride trends ranged from -5.0 to 48.9 percent and trended upward at most sites, similar to calcium and magnesium (table 8; fig. 12). Chloride increased significantly during 1989-2013 at five sites and by a lesser, nonsignificant amount at three sites. Significant uptrends also were observed during 2002-13 at Morgan Creek near White Cross (site S9), White Oak Creek (site S11), and Cane Creek Reservoir, and during 1991-2001 at Jordan Lake at Bells Landing (site L8). For the Cape Fear River near Brickhaven (site S13), sodium also trended upward during 1989-2001, but the trend was not statistically significant.

Evidence is increasing that urbanization raises specific conductance and concentrations of major ions in downstream waters through nonpoint-source inputs. Increases in calcium and magnesium in streams have been attributed to weathering of concrete and other carbonate materials, and increases in sodium and chloride have been related to road-salt runoff (Kaushal and others, 2017; Moore and others, 2017). Likewise, increasing chloride concentrations in North American lakes have been attributed to road-salt application (Dugan and others, 2017). In the current study, some of the largest percent increases in major ion concentrations were observed at White Oak Creek (site S11), where calcium, sodium, and chloride increased by more than 40 percent during the 12-year period 2002-13. The White Oak Creek watershed (site S11) had the greatest increase in developed land cover as well as pronounced increases in major ion concentrations and specific conductance during the entire study period. For other sites with significant increases in specific conductance, such as sites S7, S8, and S10, data were insufficient to assess trends in individual ions. Because increasing concentrations of ions have implications for water treatment, agricultural use, and aquatic health, it could be beneficial to obtain sufficient data to track future trends at additional locations in the study area.

Although urbanization also has been associated with increasing sulfate concentrations in other areas, sulfate in the Triangle area trended downward at most sites (table 8; fig. 13). Sulfate trends ranged from -42.9 to 27.4 percent. Concentrations increased significantly during 1989-2013 at only two sites-University Lake (L5) and Jordan Lake at Buoy 12 (L6); these uptrends were similar to uptrends for the previous ions. Sulfate concentrations for the remaining sites trended downward or remained relatively unchanged, in sharp contrast to uptrends for most of the other major ions. Sulfate concentrations in atmospheric deposition have declined during the last several decades due to advances in air-pollution controls, which may have contributed to the observed downward trends.

The previous discussion focused on percent changes (either increasing for decreasing) in major ion concentrations. The effects of the trends on water quality, however, need to be assessed both in terms of the relative (percent) changes and with respect to actual concentration changes (table 8). A large percent change at one site may not have as much effect (in terms of concentrations) as a smaller percent change at another site. For example, some of the largest percent increases in 


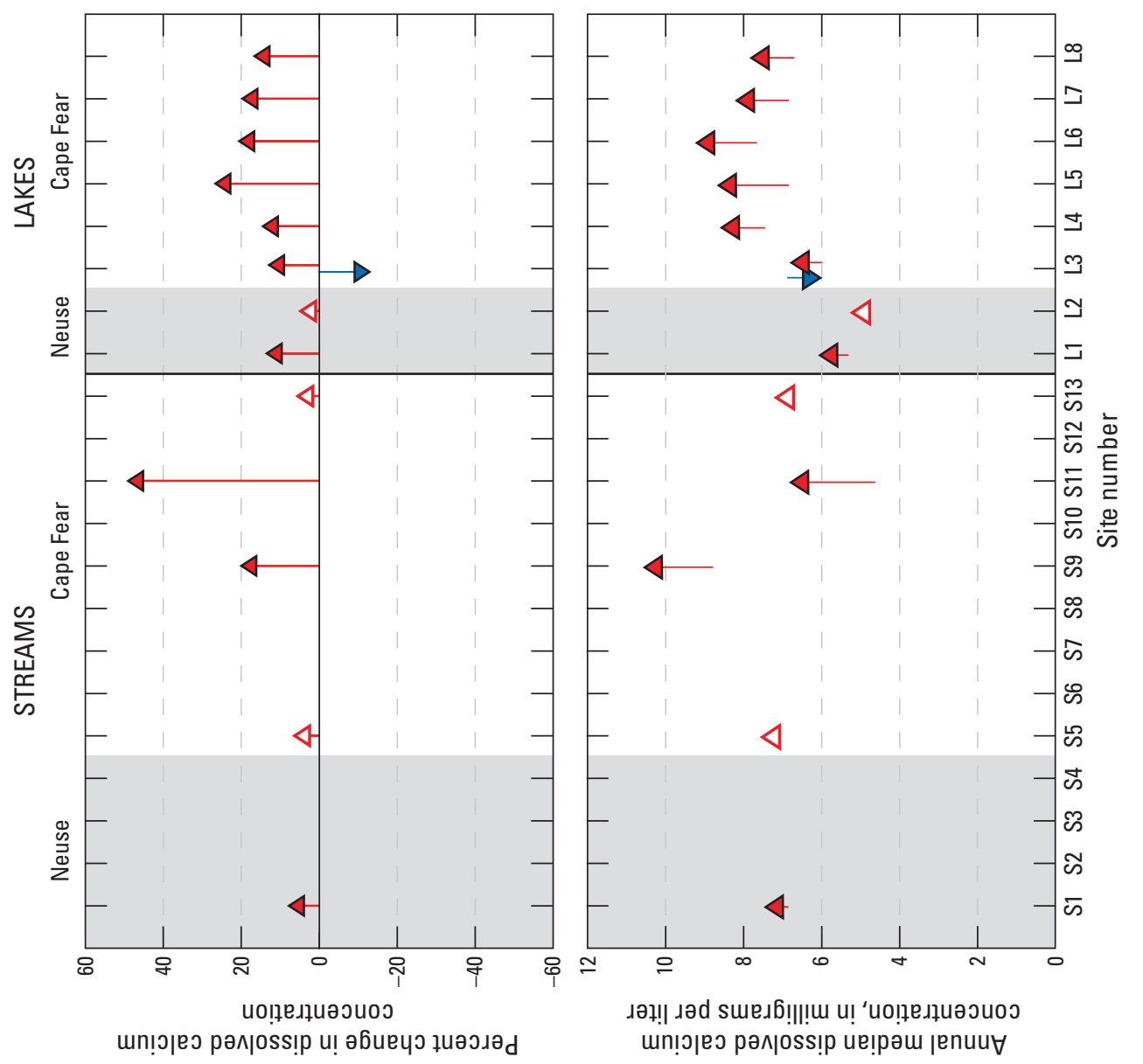

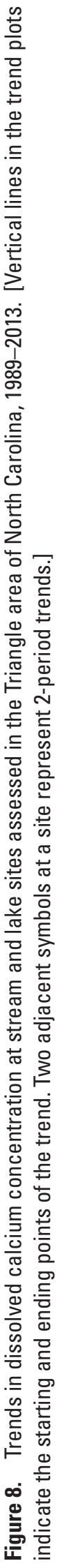

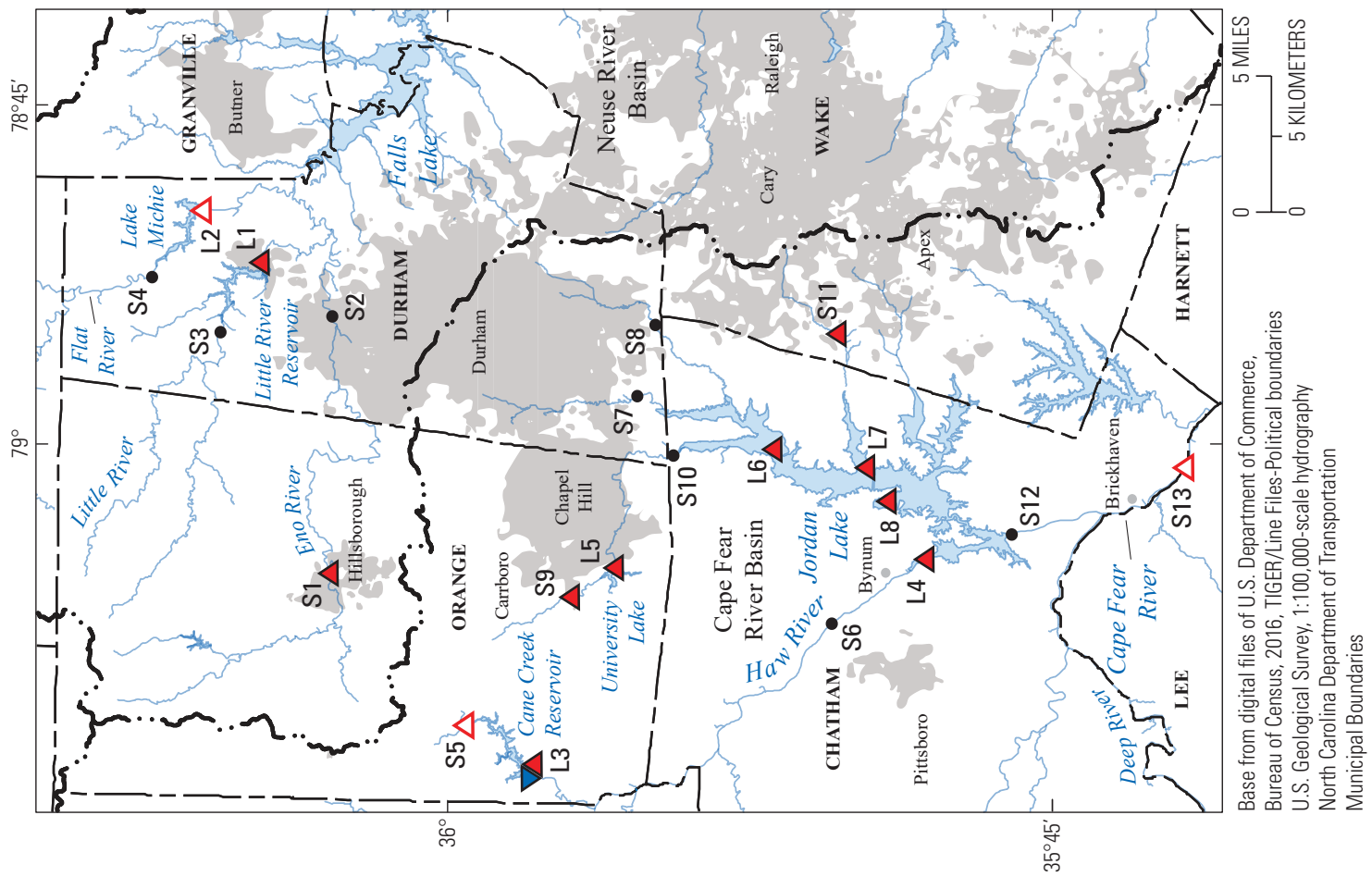



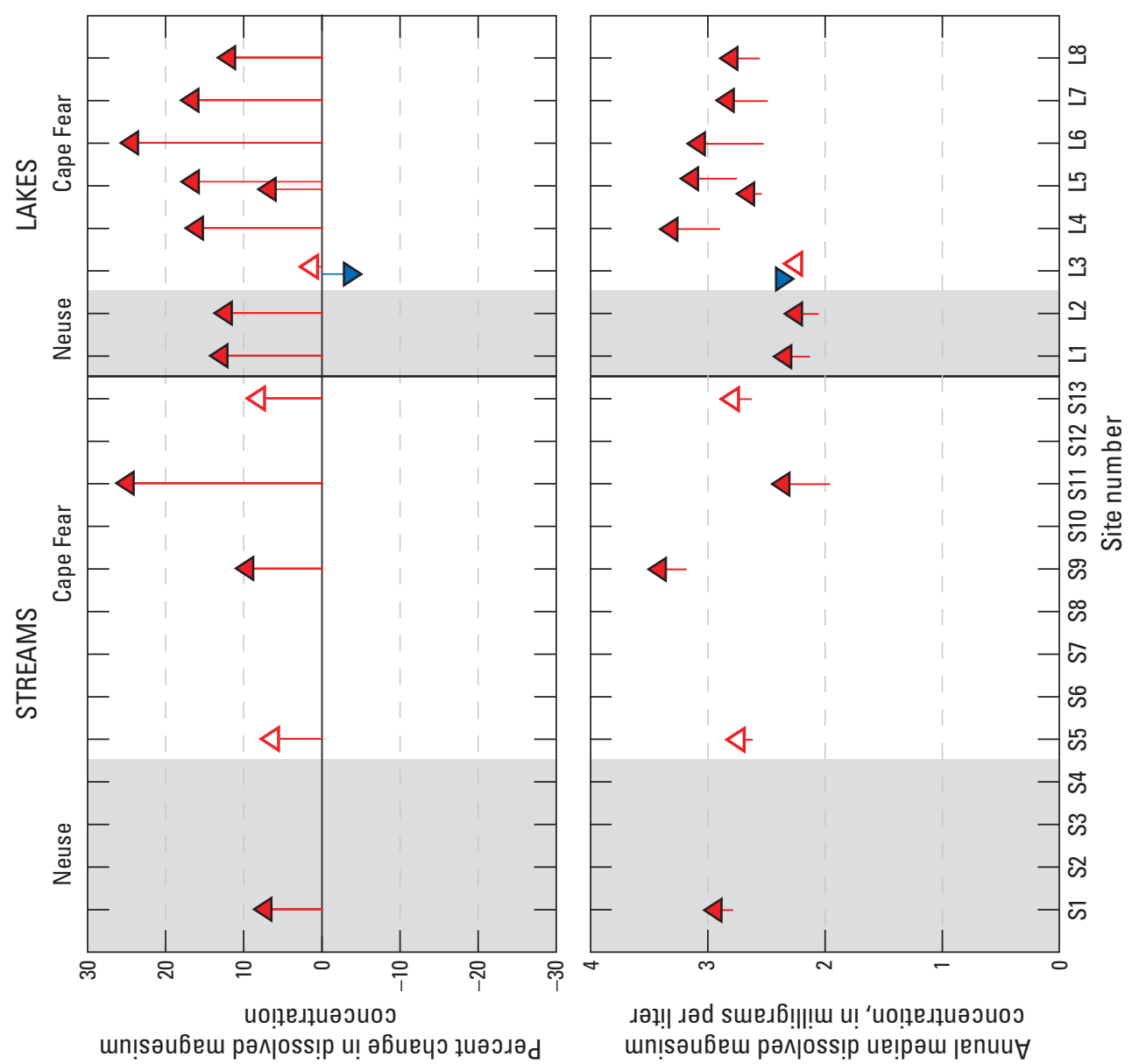

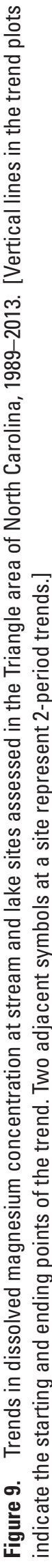

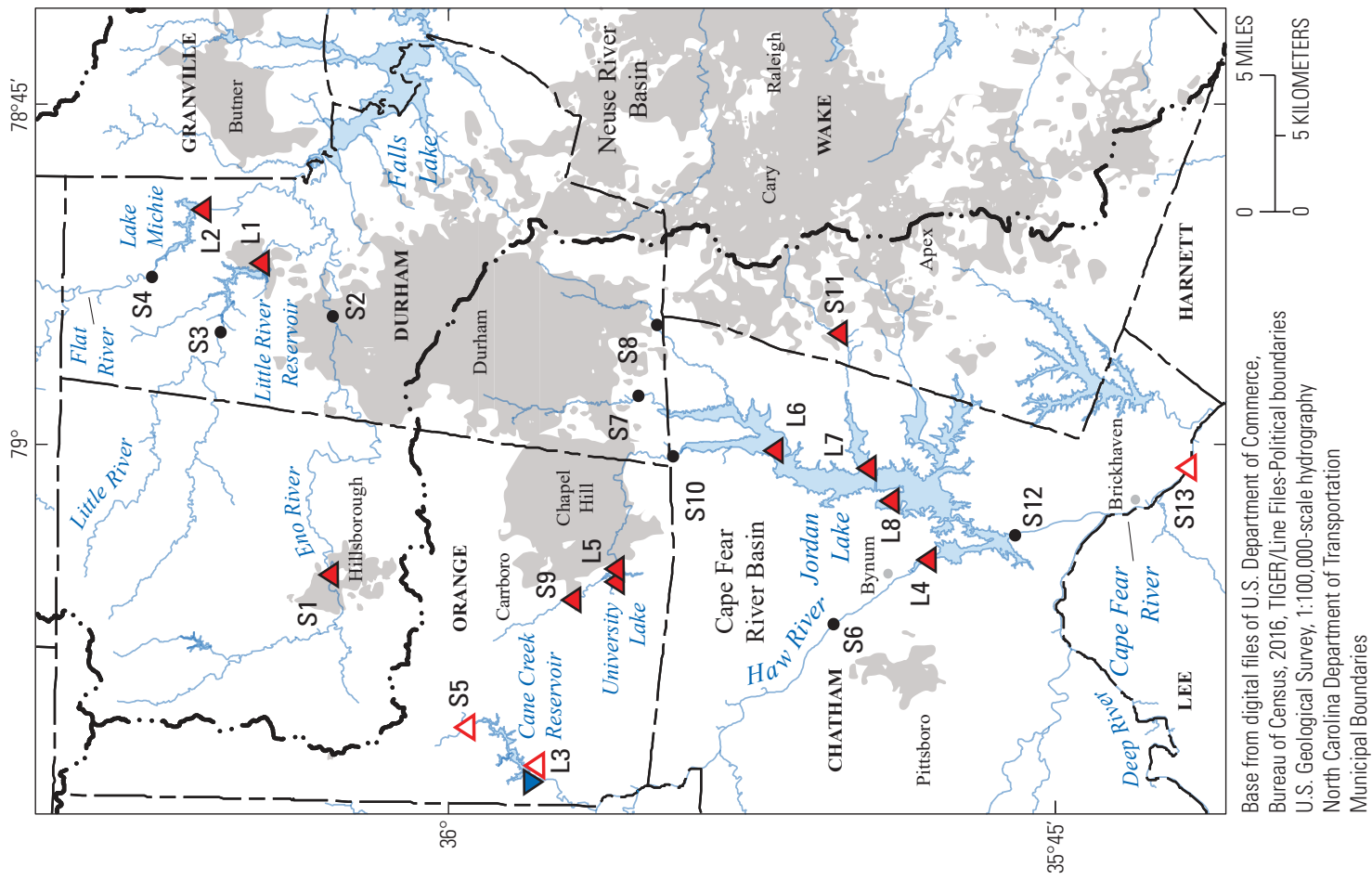



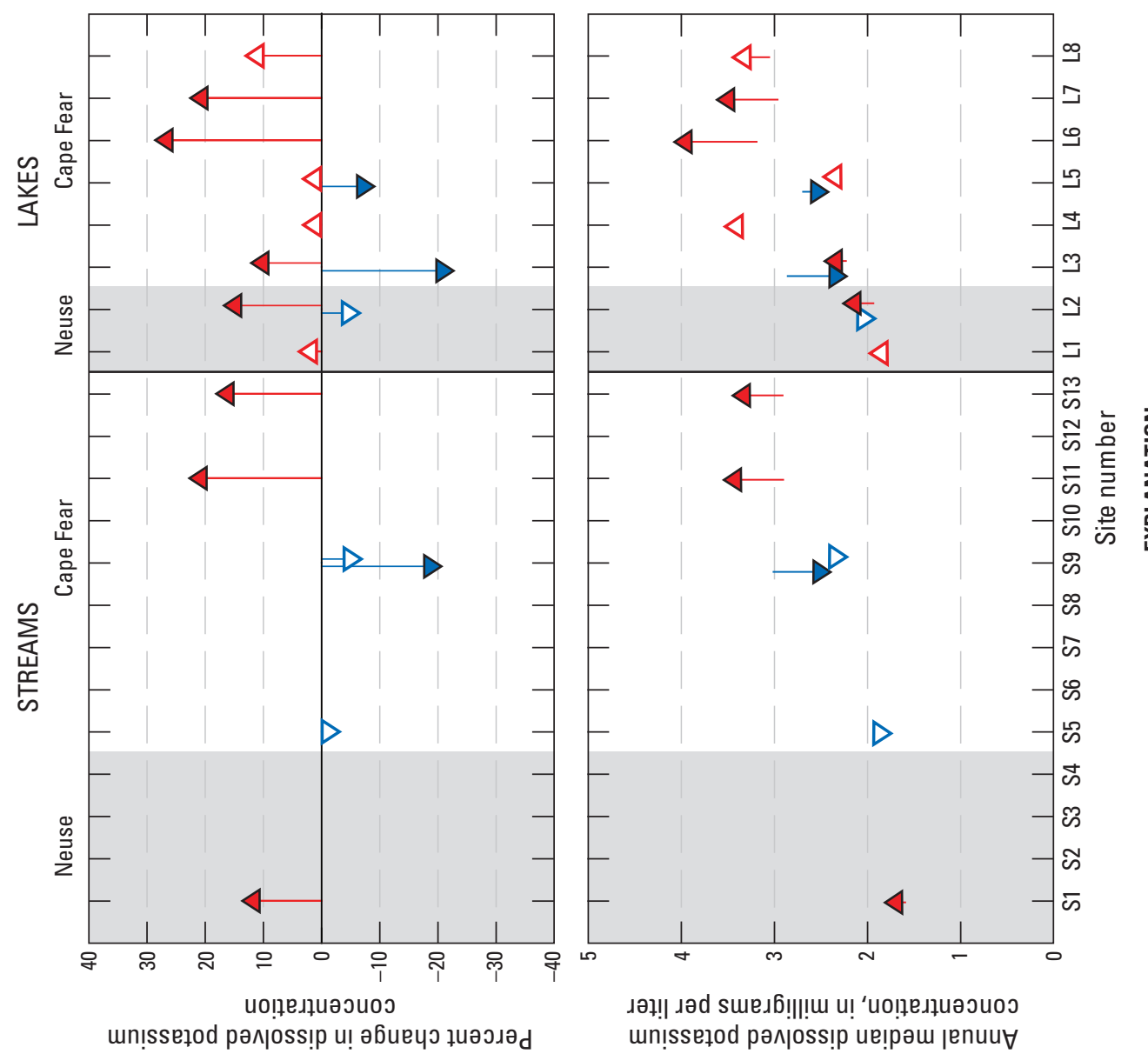

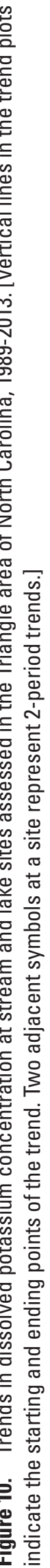

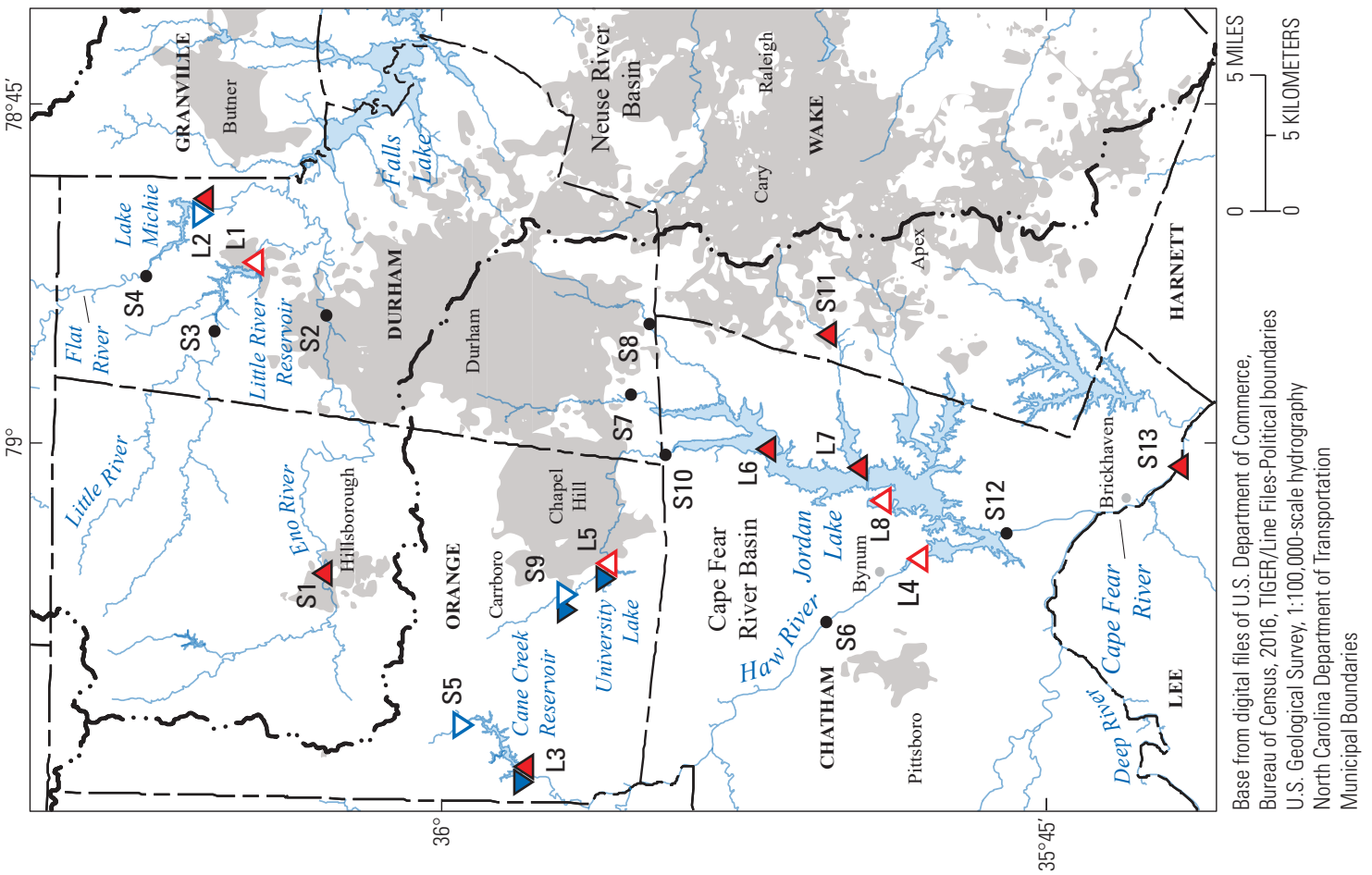



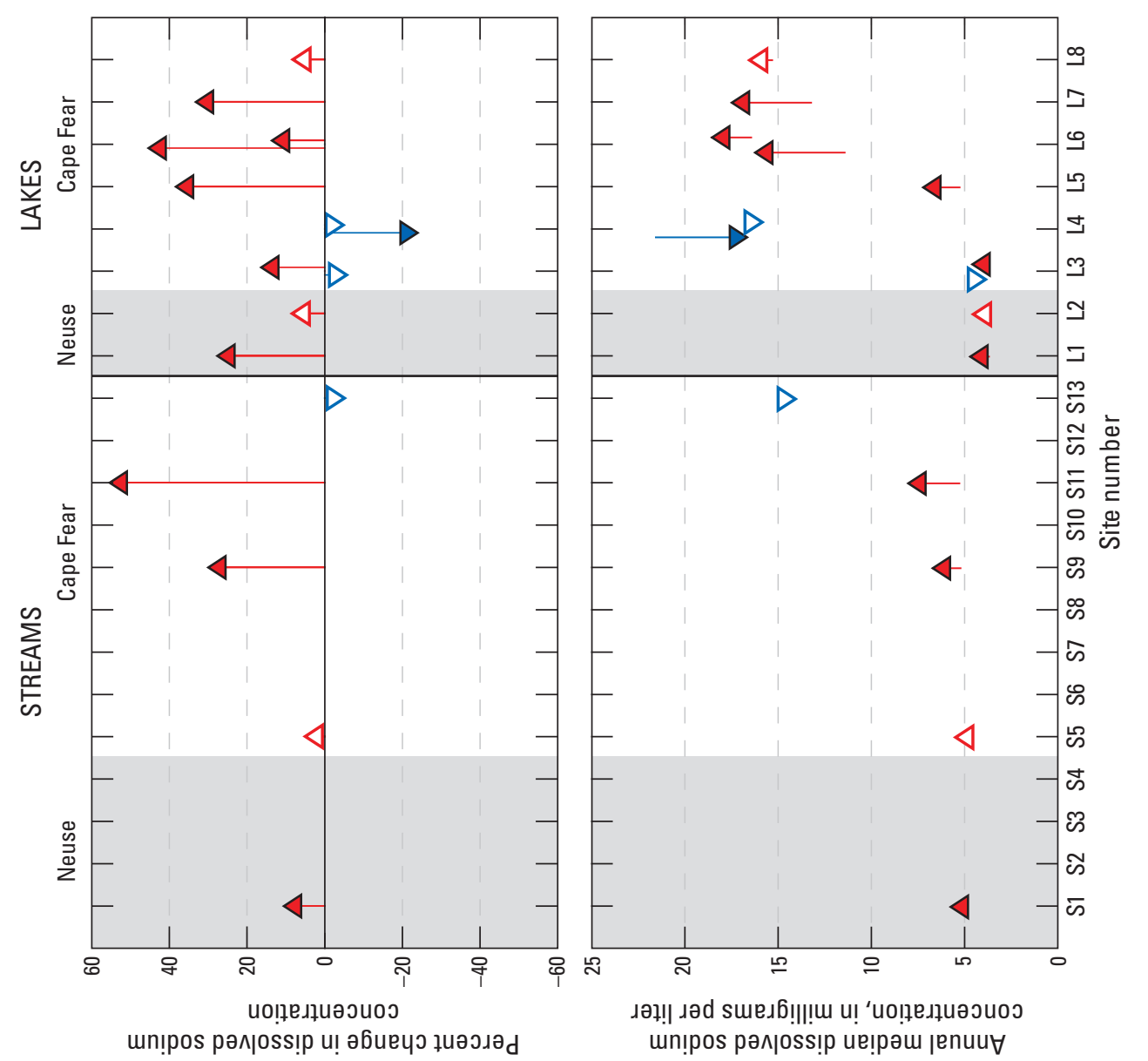

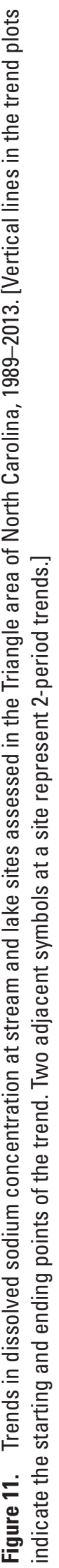

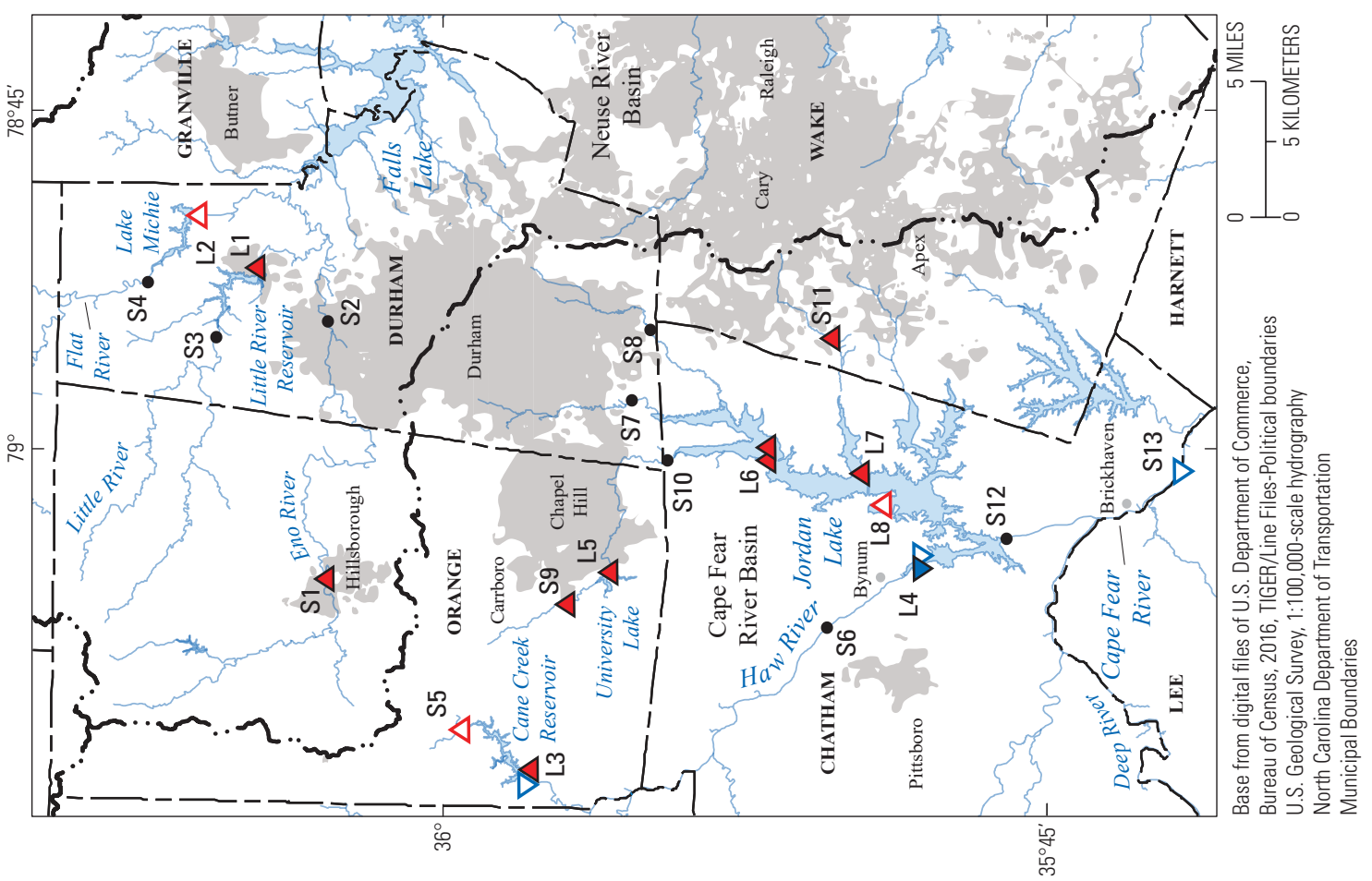



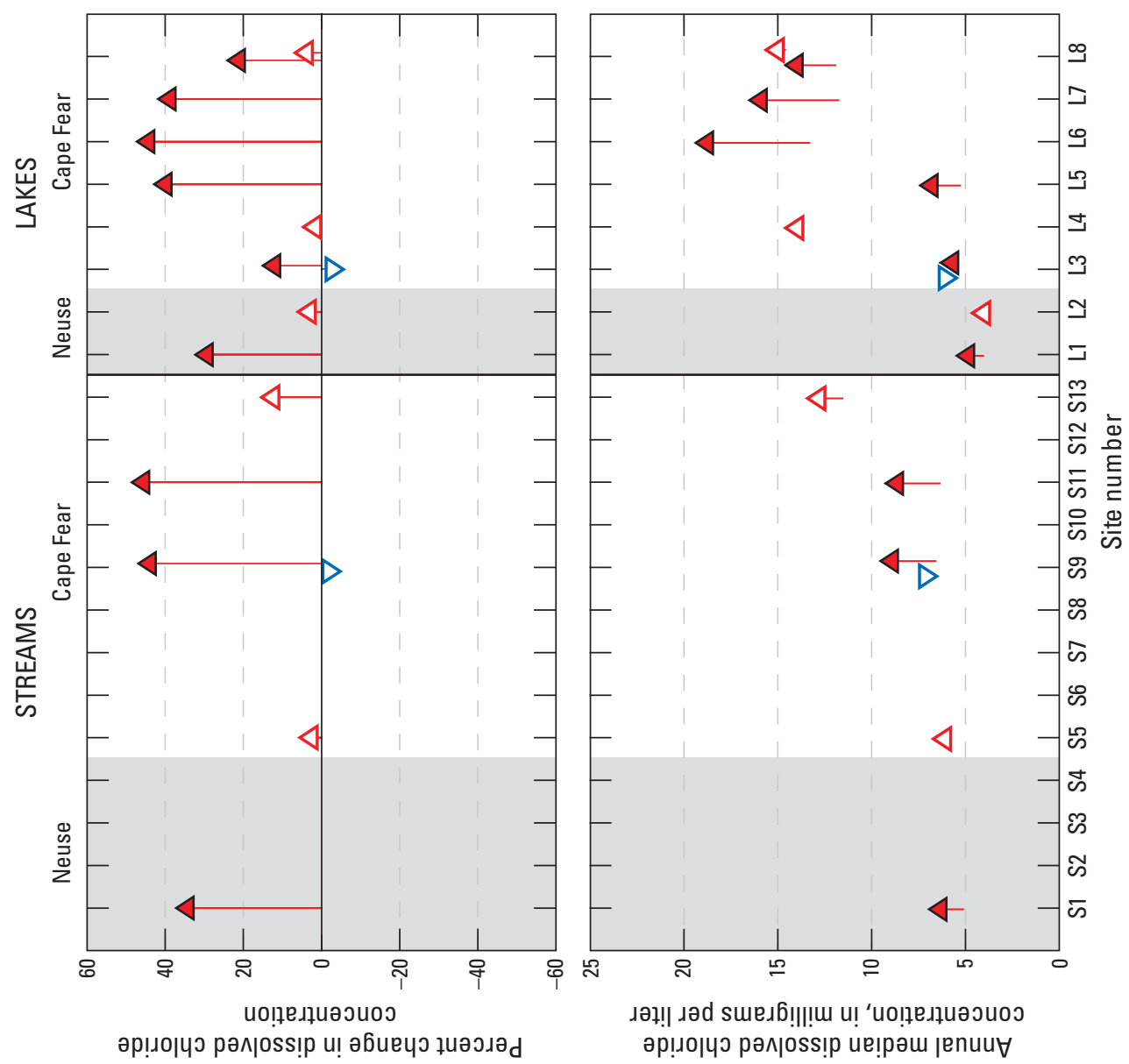

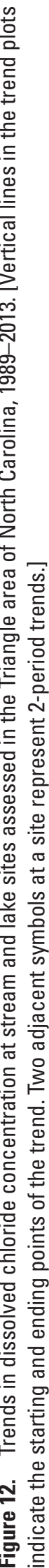

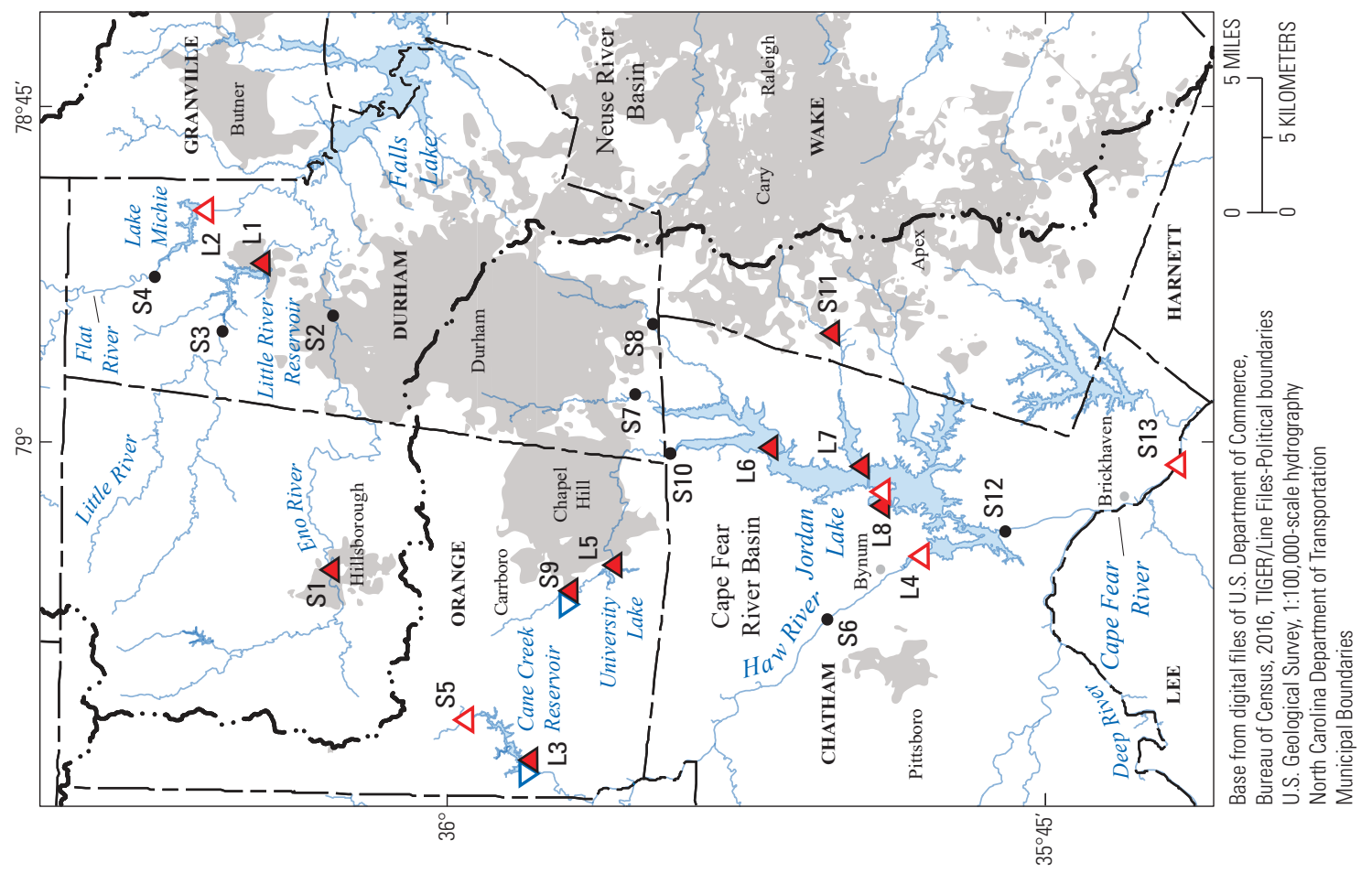




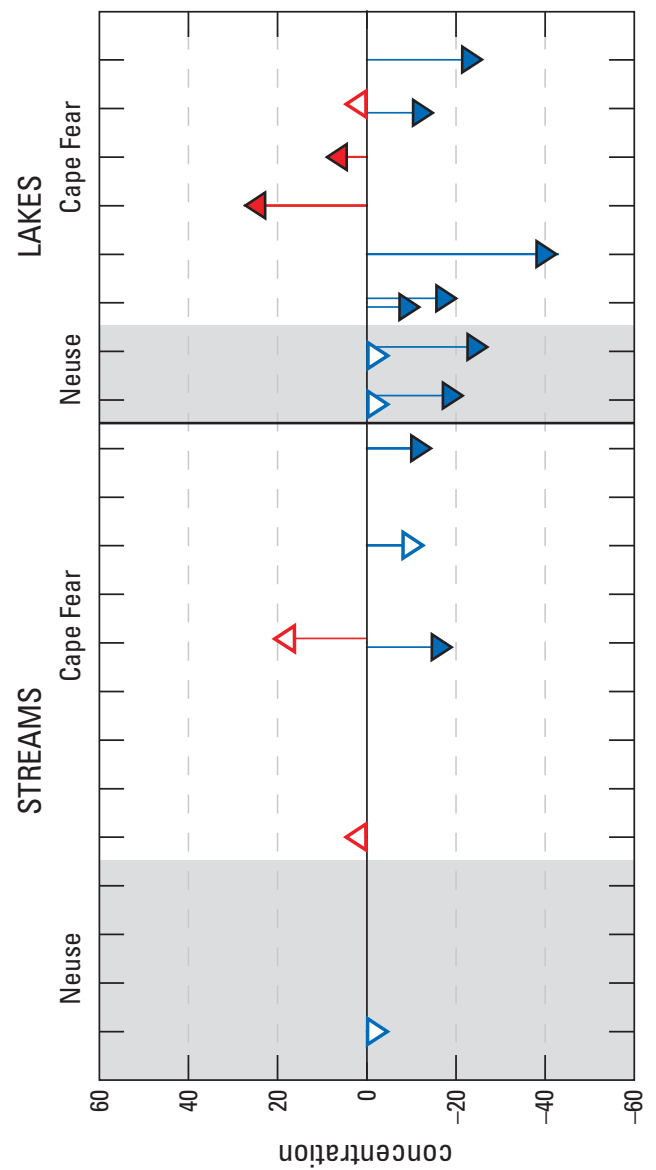

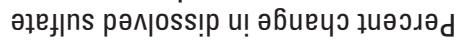

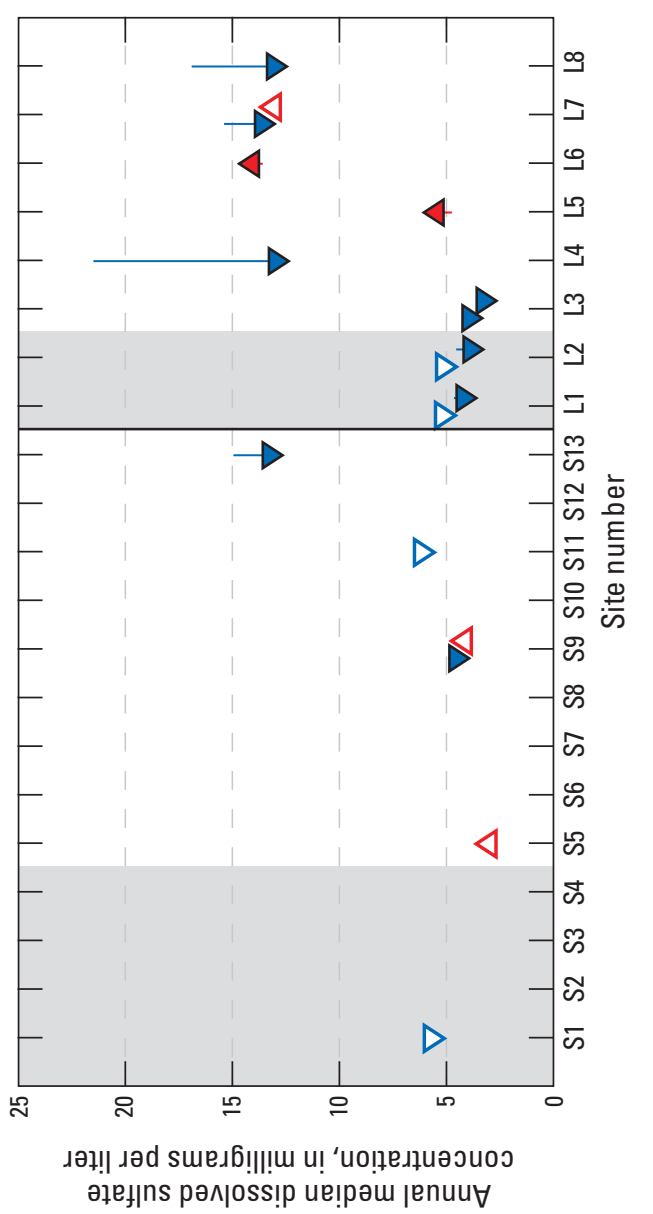

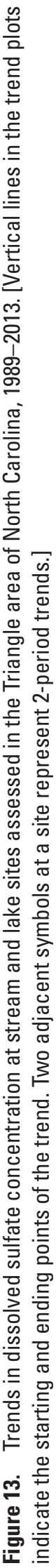

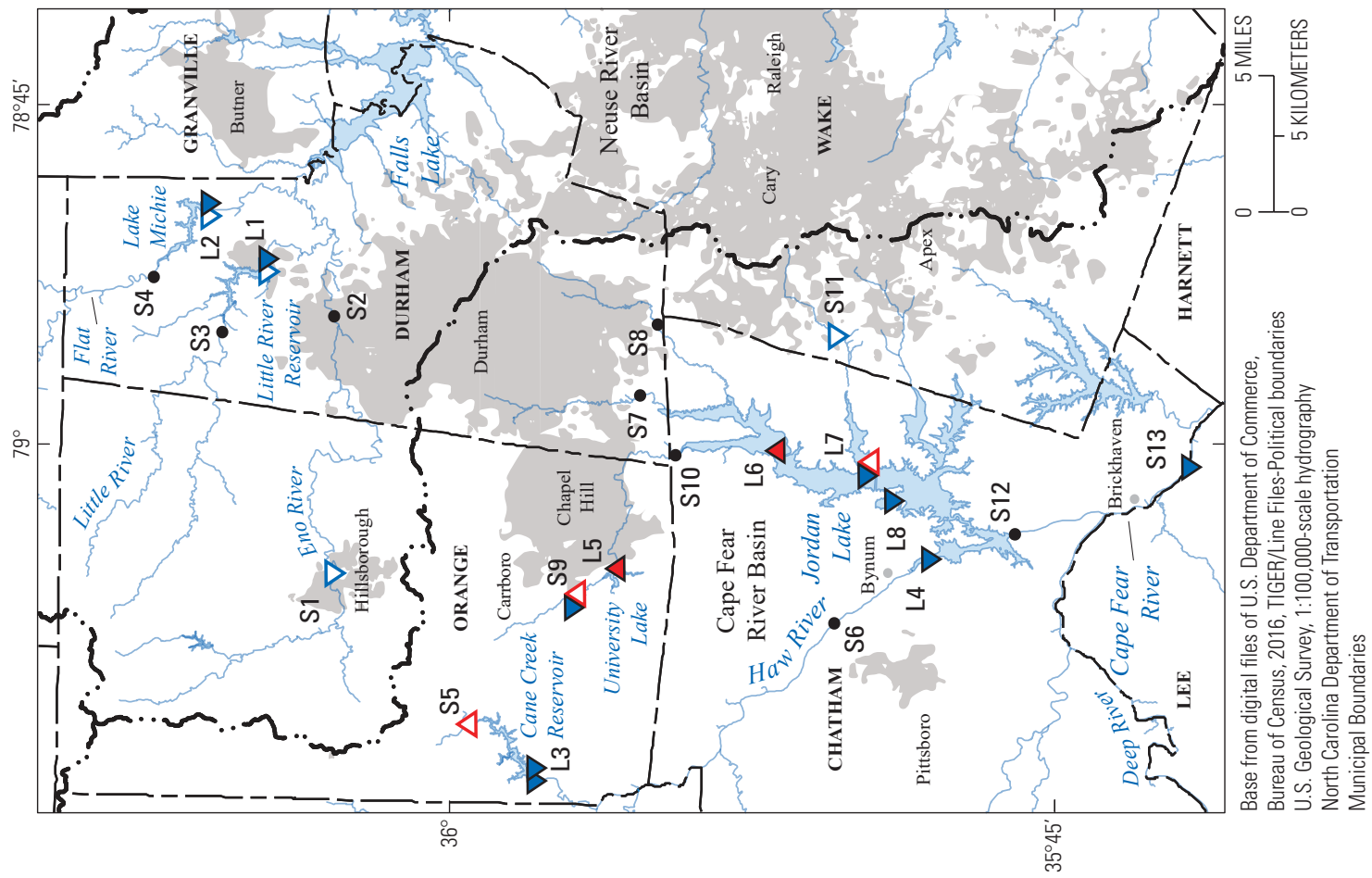


major ions were observed at White Oak Creek (site S11). However, concentrations of these ions for site S11 at the end of the trend assessment period (2013) were still low compared to many other sites (figs. 8, 11, 12).

Among the lake sites, University Lake (L5) had some of the largest percent increases in sodium, chloride, and sulfate concentrations. However, concentrations in 2013 for site L5 were still well below concentrations for several other lake sites (figs. 11, 12, 13). Two lake sites, Jordan Lake at Buoy 12 (L6) and Jordan Lake above U.S. Highway 64 (L7) had large percent increases in sodium and chloride concentrations during 1993-2013 and 1991-2013, respectively, and also had the highest concentrations of those ions in 2013 compared to all of the remaining sites (figs. 11, 12). For site L6, the annual median sodium concentration increased from about 11.3 to $18.5 \mathrm{mg} / \mathrm{L}$ from 1993 to 2013, and the annual median chloride concentration increased from about 13.3 to $19.3 \mathrm{mg} / \mathrm{L}$ during the same period.

It is interesting to note that specific conductance for three stream sites upstream from the New Hope arm of Jordan Lake (S7, S8, and S10) had the largest increases in specific conductance during the study period and by far the highest specific conductance in 2013 (fig. 7). Although major ion trends were not available for these sites, the specific conductance trends indicate that the source of the increasing major ion concentrations in Jordan Lake is probably the upstream tributaries.

Trend results for sulfate (fig. 13) provide an interesting contrast to the trends observed for other major ions. Like sodium and chloride, significant uptrends in sulfate concentrations were observed for lake sites at University Lake (L5) and Jordan Lake at Buoy 12 (L6). However, sulfate concentrations for lake sites at Cane Creek Reservoir (L3), Haw River arm of Jordan Lake (L4), and Jordan Lake at Bells Landing (L8) trended strongly downward. Similarly, for several sites in the upper Neuse River Basin portion of the study area (S1, L1, and L2), sulfate concentrations decreased in contrast to increases in specific conductance and concentrations of all the other ions (figs. 7-13).

\section{Nutrients and Organic Carbon}

Nitrogen and phosphorus are the primary elements essential for plant and animal nutrition. Nutrient dynamics in streams and lakes differ. Excessive concentrations of nutrients accelerate the eutrophication of lakes, which can lead to water-quality problems like algal blooms, nuisance macrophyte growth, fish kills, taste-and-odor problems, and loss of biodiversity and recreational enjoyment. Nutrient enrichment primarily affects lakes; however, similar water-quality problems may be observed in slow-moving streams.

In this study, data were sufficient to assess trends for total organic nitrogen, total nitrogen, and total phosphorus at all of the stream and lake sites (table 8). Data for 19 sites were sufficient to evaluate both 1- and 2-period trend models for the entire trend period. Data for White Oak Creek (site S11) were sufficient to evaluate trends only for the late time period
(2002-13), and data for Haw River below Jordan Dam (site S12) were sufficient to evaluate trends for only the early time period (1989-2000). As described below, trends for nitrate or ammonia were not reported at several sites where more than 20 percent of the observations were below reporting levels.

Nitrogen occurs in water in several chemical forms and is cycled through the atmosphere, hydrosphere, biosphere, and lithosphere through a complex set of chemical and biological processes. The major forms of nitrogen that occur in water include nitrate plus nitrite, ammonia, and total organic nitrogen. Nitrate is the predominant form of inorganic nitrogen in surface waters, typically occurring with lesser amounts of nitrite and ammonia. For this study, nitrate and nitrite were analyzed as a combined fraction; these results hereafter are referred to as "nitrate." Nitrate concentrations in excess of $10 \mathrm{mg} / \mathrm{L}$ as $\mathrm{N}$ may cause methemoglobinemia ("blue baby syndrome") in young children (North Carolina Department of Health and Human Services, 2018); therefore, concentrations of nitrate in water supplies have been studied extensively. In the Triangle area, concentrations of nitrate above $10 \mathrm{mg} / \mathrm{L}$ were occasionally observed during the trend period at three stream sites, including New Hope Creek (S7), Northeast Creek (S8), and Morgan Creek near Farrington (S10); these sites also had the highest median concentrations of nitrate during the trend period (table 6). In contrast, the maximum concentration of nitrate observed at lake sites was $1.70 \mathrm{mg} / \mathrm{L}$-well below $10 \mathrm{mg} / \mathrm{L}$. Overall, 45.2 percent of lake-sample values were censored (table 5). Nitrate typically was below detection at these lake sites during summer months, likely due to assimilation by phytoplankton, and was more likely to be detected during fall turnover, winter, and early spring. At seven lake sites, more than 30 percent of samples had concentrations below reporting levels. At the remaining lake site, Jordan Lake near Hanks Chapel (L4), the median nitrate concentration during the trend period was an order of magnitude higher than at other lake sites (table 7).

Nitrate trends were assessed at 14 sites, including 13 stream sites and 1 lake site (table 8). Statistically significant, downward trends in nitrate concentrations were observed at five sites for the 1989-2013 period; downward but nonsignificant trends were observed at another three sites (table 8; fig. 14). It should be noted that many of these downtrends represented little change in terms of actual nitrate concentrations. However, a pronounced change occurred at Northeast Creek (site S8), where nitrate concentrations declined by 75.5 percent after July 2005, when an upstream WWTP implemented nitrogen-removal practices. This step trend corresponded to a substantial $(4.317 \mathrm{mg} / \mathrm{L})$ decrease in annual fitted median concentrations. During 1989-2000, nitrate decreased significantly at Haw River below Jordan dam (site S12). Nitrate concentrations at White Oak Creek (site S11) increased 86.2 percent during 2002-13, which was the maximum percent increase observed during the study; however, the magnitude of change was very small, with annual median concentration increasing only $0.028 \mathrm{mg} / \mathrm{L}$ (from 0.034 to $0.062 \mathrm{mg} / \mathrm{L}$ ) during that period. 


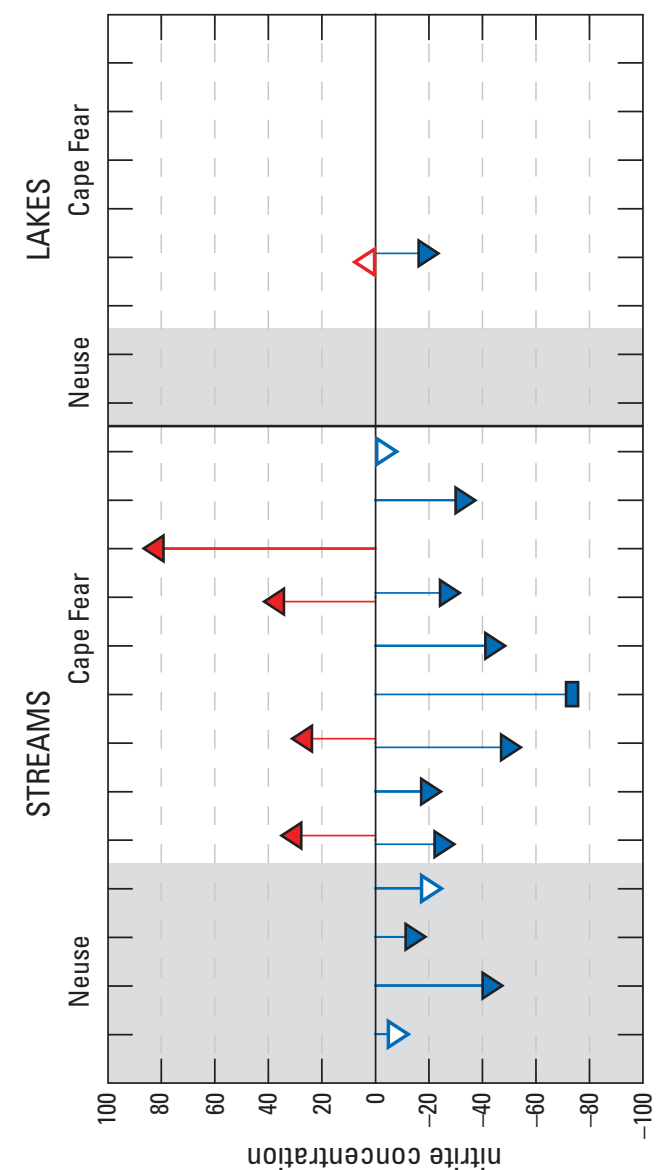

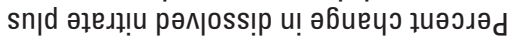

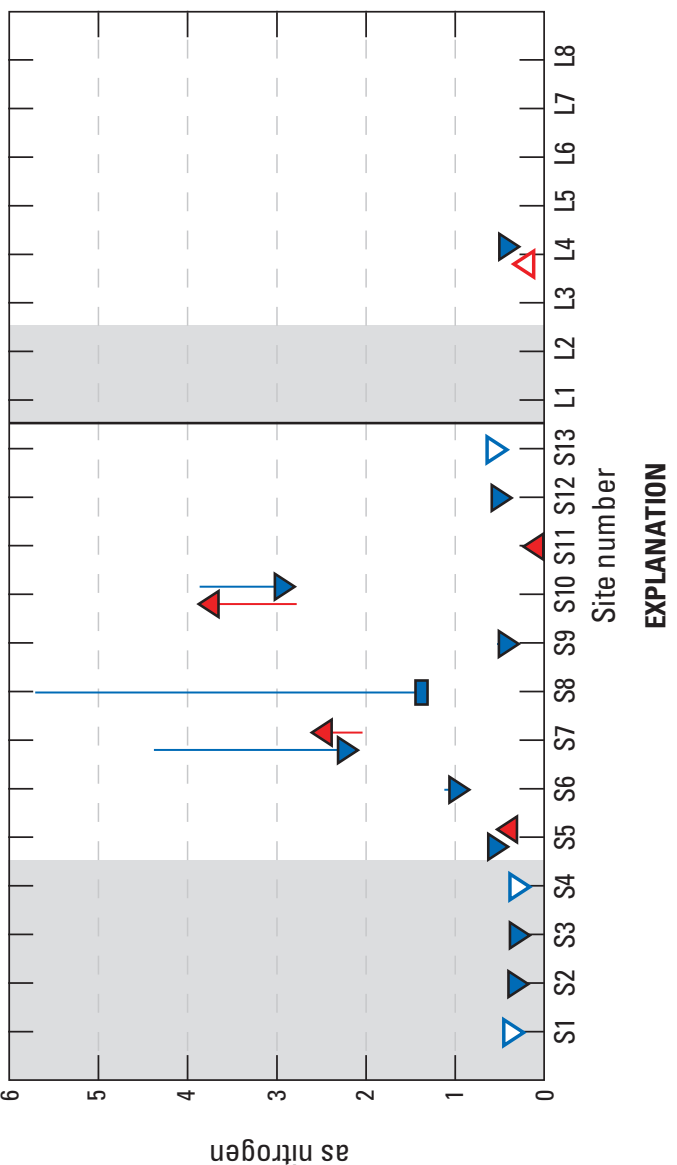

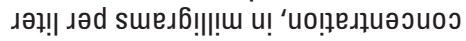
әฺ!

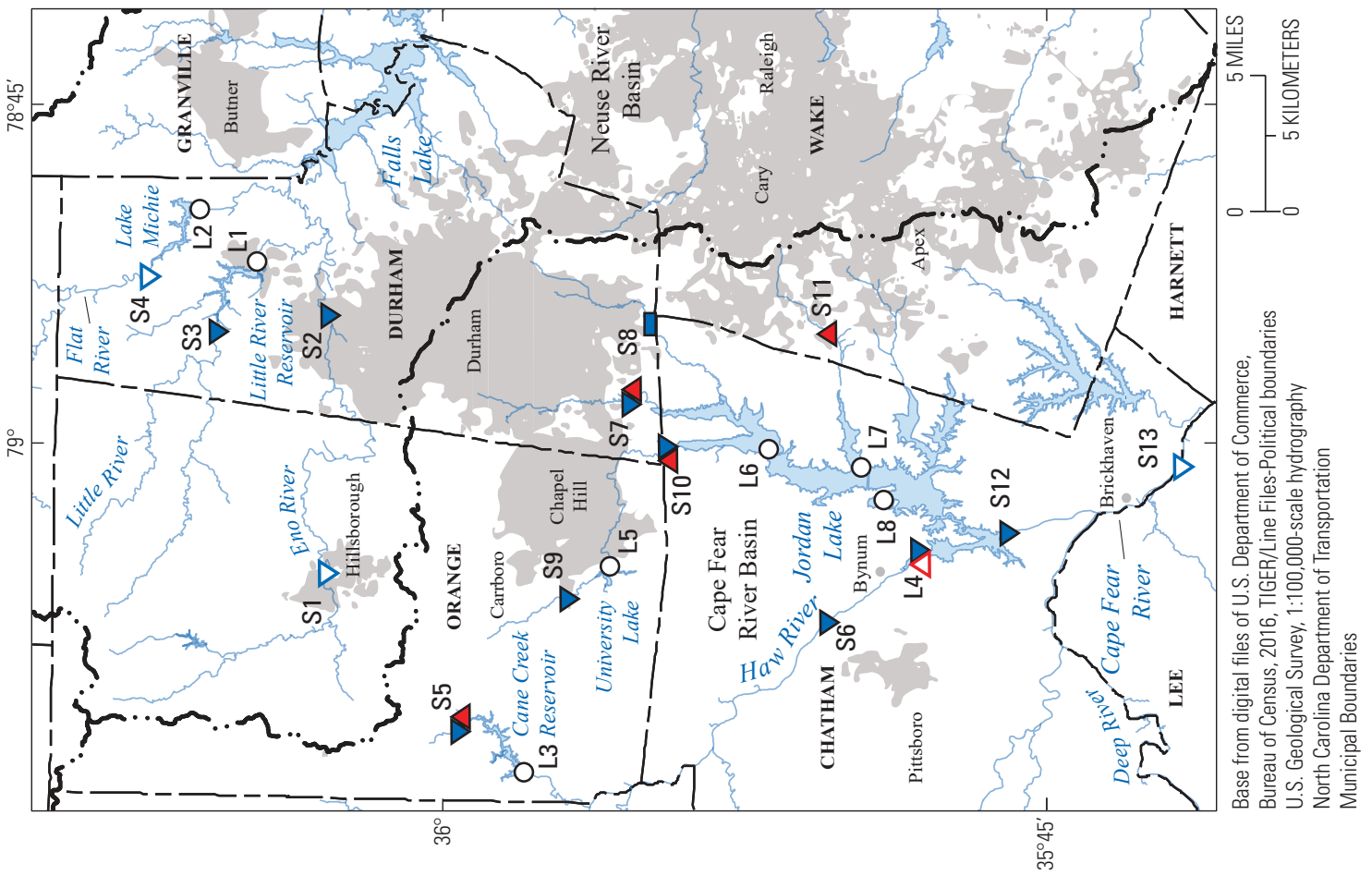


Two-period trend analysis for nitrate showed mixed results at the remaining four sites. At New Hope Creek (site S7), annual median concentrations decreased $1.720 \mathrm{mg} / \mathrm{L}$ overall from 1989 to 2013, with a significant downtrend during 1989-2001 followed by a significant, but smaller, uptrend during 2002-13. In 1994, a major municipal WWTP upstream from site S7 implemented biological nutrient removal, which may have contributed to decreasing nitrate concentrations during the early trend period (Sydney Miller, City of Durham, Department of Water Management, written commun., March 2, 2018). The maximum-magnitude increase in nitrate concentrations was observed at Morgan Creek near Farrington (site S10), where annual fitted medians rose $1.090 \mathrm{mg} / \mathrm{L}$ from 1989 to 2001; however, this uptrend was offset by a $1.163 \mathrm{mg} / \mathrm{L}$ decrease from 2002 to 2013 (table 8; fig. 14). In 2007, a major municipal WWTP upstream from site S10 installed deep-bed denitrification filters, which may have contributed to decreasing nitrate concentrations during the late trend period (Sandra Bradshaw, Orange Water and Sewer Authority, written commun., February 28, 2018). It is interesting that the largest reductions in nitrate occurred at sites S7, S8, and S10 during the late trend period, despite considerable development and population growth in these watersheds; however, annual median nitrate concentrations in 2013 remained higher than at other sites in the study area (fig. 14). In an analysis of nutrient yields among 48 streams in central and eastern North Carolina, Harden and others (2013) noted that high point-source contributions (greater than 10 percent of total streamflow) had a major influence on nitrate and total nitrogen yields. Nitrate trends observed at sites S5 and L4, while statistically significant, accounted for small changes in actual concentrations. In other water-quality trend studies, decreases in stream nitrate concentrations have been associated with decreases in agricultural land use. However, in the Triangle area, agricultural land uses were generally stable during the trend period (table 3 ).

Ammonia is produced when microorganisms decompose or convert organic matter that contains nitrogen. Ammonia is rapidly transformed to other forms of nitrogen when oxygen is present and is readily utilized by phytoplankton. Not surprisingly, therefore, ammonia concentrations in Triangle area streams and lake (near-surface) samples were generally low. The median ammonia concentration was $0.040 \mathrm{mg} / \mathrm{L}$ as $\mathrm{N}$ among all stream samples and $0.020 \mathrm{mg} / \mathrm{L}$ among all lake samples. For stream samples, 19.6 percent of values were censored (below reporting limits), and 24.8 percent of lake-sample values were censored (table 5). In lakes, ammonia typically was below detection during summer months when phytoplankton were relatively more abundant and upper waters were well oxygenated.

Ammonia trends were not reported for the five stream sites (table 6) and four lake sites (table 7) where more than 20 percent of the data were censored. Sufficient uncensored data were available to analyze trends in ammonia at eight stream sites and four lake sites (table 8; fig. 15). From 1989 to 2013, ammonia significantly decreased at New Hope Creek (site S7) and showed a smaller, nonsignificant downtrend at Jordan Lake near Hanks Chapel (site L4). At Northeast Creek (site S8), a downward step trend ( 57.3 percent; $0.078 \mathrm{mg} / \mathrm{L}$ ) corresponded to nitrogen-removal implementation at the upstream WWTP in July 2005. During the earlier period of 1989-2001, statistically significant, downward trends were noted at seven additional sites (table 8; fig. 15). At Lake Michie (site L2) and Cane Creek Reservoir (site L3), ammonia concentrations decreased from 1989 to 2001, then increased from 2002 to 2013. However, despite the recent uptrends, annual median ammonia concentrations for those sites in 2013 remained well below the values in 1989. The reasons for the prevailing downtrends in the study area are unclear other than for the previously described step trend at site S8.

Total organic nitrogen (TON) in water consists of living organisms, such as phytoplankton and zooplankton, suspended and dissolved materials transported from upstream sources, and various intermediate products of organic matter decomposition. At stream sites, the maximum TON value observed during the trend period of 1989-2013 was $4.4 \mathrm{mg} / \mathrm{L}$ as N at Cane Creek (site S5); Northeast Creek (site S8) had the highest median concentration $(0.81 \mathrm{mg} / \mathrm{L}$; table 6$)$. In general, concentrations were lower at stream sites in the Neuse River Basin than in the Cape Fear River Basin (table 6). Among lake sites, Jordan Lake at Farrington (site L6) had the maximum TON concentration $(3.4 \mathrm{mg} / \mathrm{L})$ as well as the highest median concentration $(0.90 \mathrm{mg} / \mathrm{L})$.

In contrast to nitrate and ammonia, concentrations of TON generally increased throughout the study area during 1989-2013 (table 8; fig. 16). Statistically significant, upward trends in TON concentrations were noted at 11 sites for the 1989-2013 period; upward but nonsignificant trends were noted at an additional 2 sites; and a downward but nonsignificant trend was noted at 1 site (L8). The largest increase of 75.0 percent $(0.35 \mathrm{mg} / \mathrm{L})$ was noted at New Hope Creek (site S7). In contrast to the substantial reductions in nitrate and ammonia that were observed at Northeast Creek (site S8), TON trended upward by 43.9 percent $(0.26 \mathrm{mg} / \mathrm{L})$ at this site, although the trend was not statistically significant. At sites with uptrends, increases in annual median concentration generally ranged from 0.05 to $0.20 \mathrm{mg} / \mathrm{L}$.

At five sites (S5, S9, L3, L6, and L7), 2-period trend models best fit the TON data. At sites S5 and L3, nonsignificant downtrends during the early period were followed by significant uptrends during the late period, resulting in higher annual median concentrations in 2013. At two sites in Jordan Lake (L6, L7), TON increased significantly through 2001, then decreased slightly from 2002 to 2013 . However, annual median concentrations at the end of the trend-analysis period remained higher than concentrations at the beginning of the record for both sites. In contrast to the generally increasing trends observed at most sites in the study area, TON decreased significantly at Morgan Creek near White Cross (site S9), where annual fitted-median concentrations decreased by $0.16 \mathrm{mg} / \mathrm{L}$ from 1989 to 2013. A nonsignificant uptrend in TON concentrations was noted at White Oak Creek (site S11) 


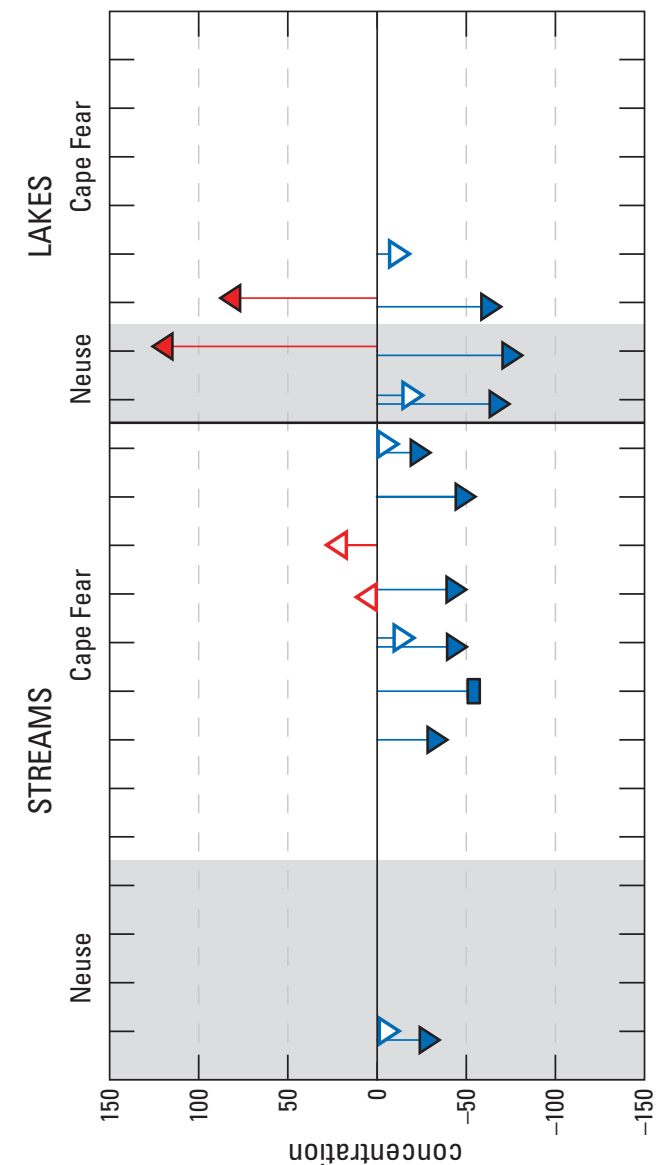

е!иошше рәл|оss!p u! әбиецэ ұиәэләd

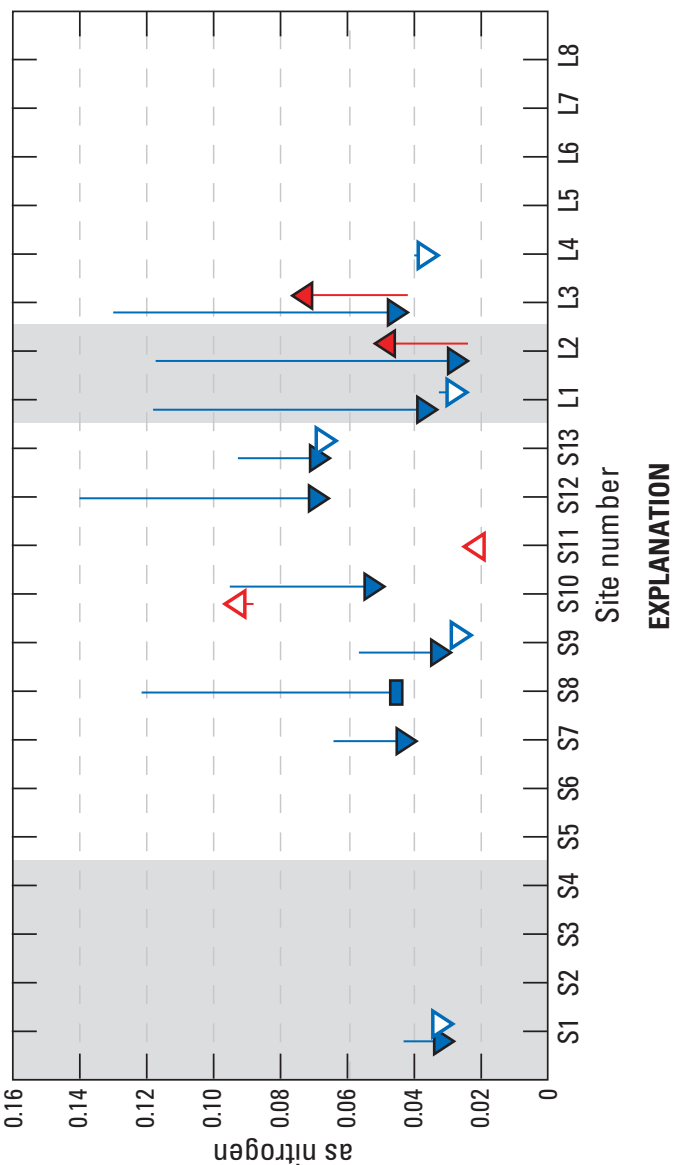

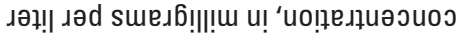
е!̣omше рәл|оss!p ие!pәш jenuu

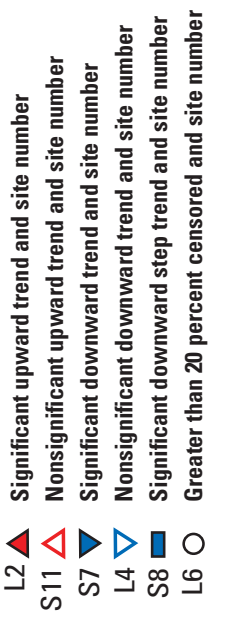

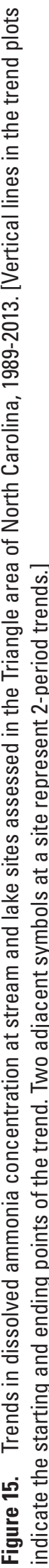

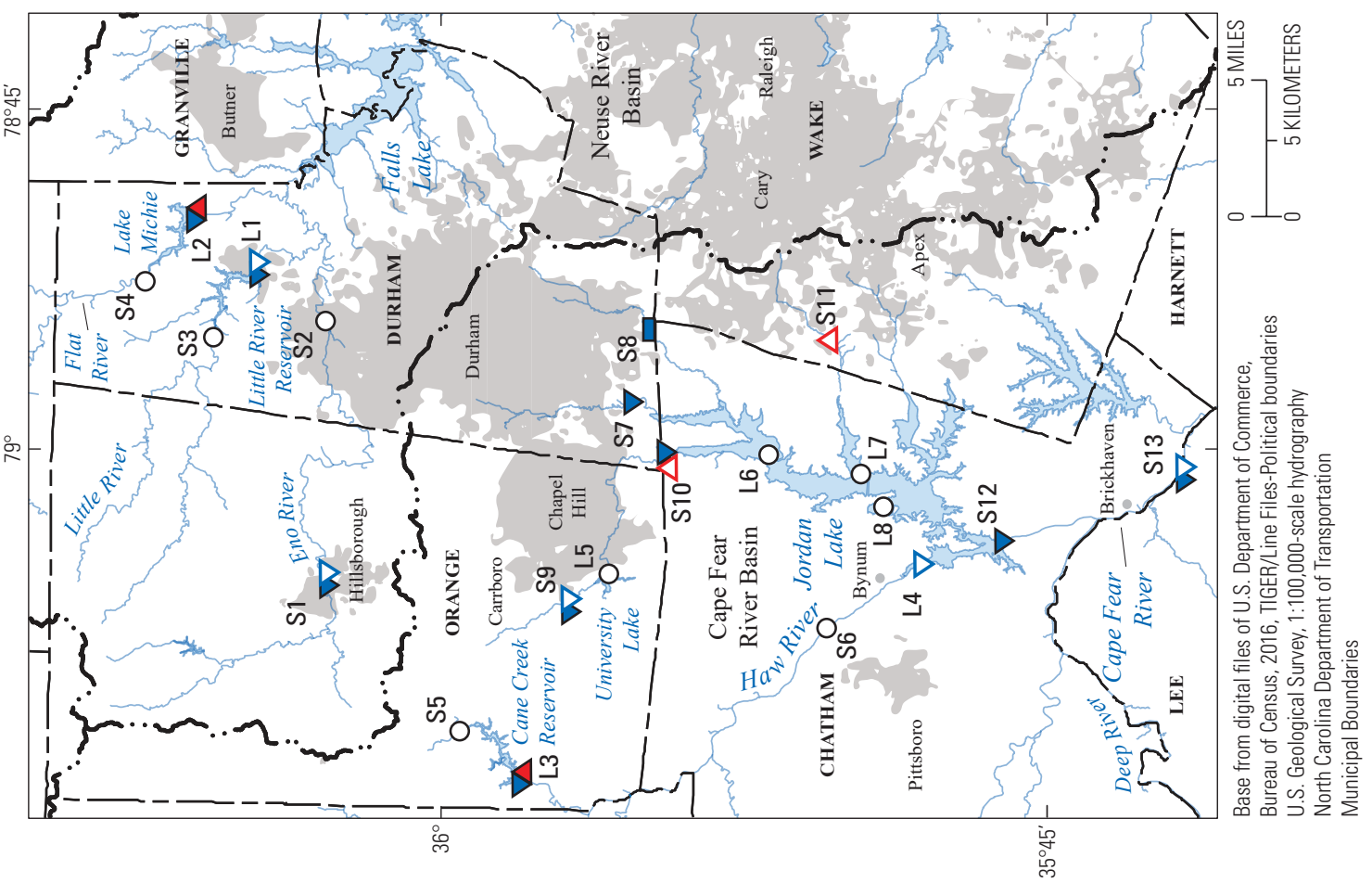



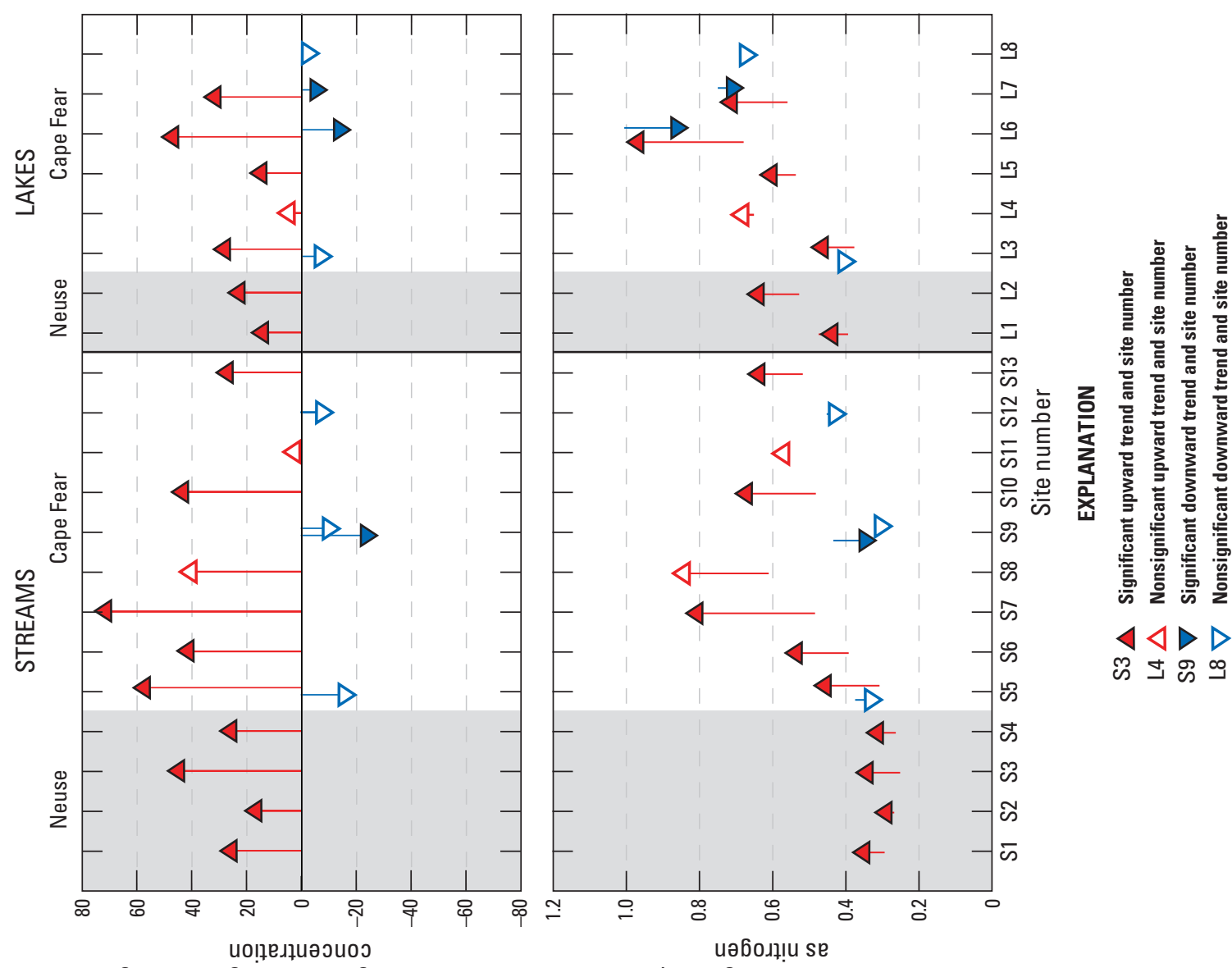

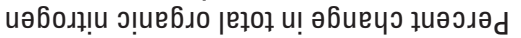

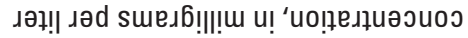

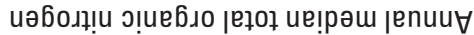

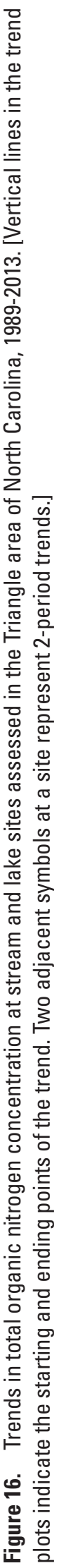

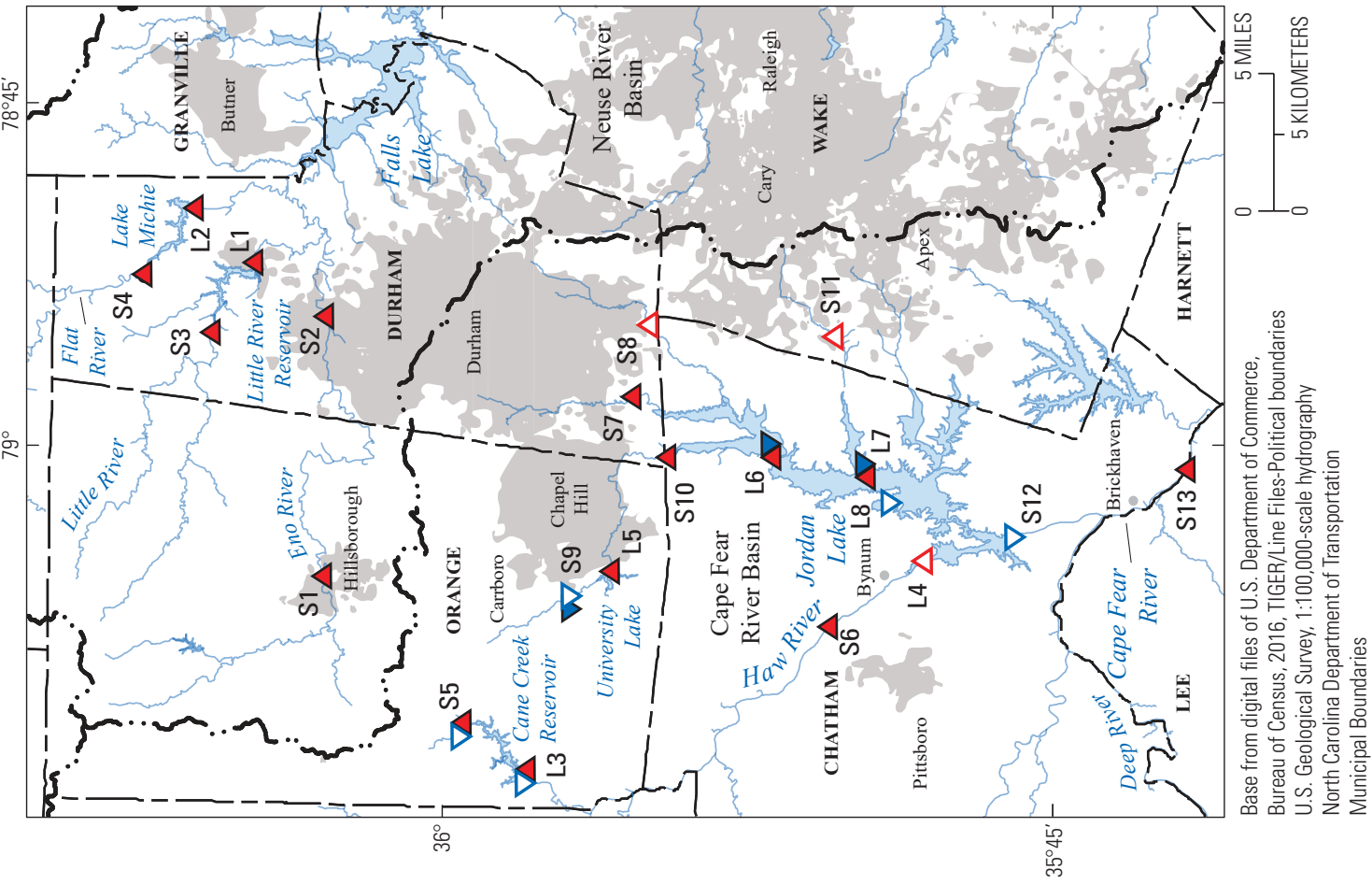


for the late period, and a nonsignificant downtrend was noted at Haw River below Jordan dam (site S12) for the early period.

Childress and Bathala (1997) previously reported downward trends in TON concentrations during 1989-95 at sites S5, S9, S12, S13, L1, and L3, which agreed with the downward trends noted at sites S5, S9, S12, and L3 during the early period (1989-2001) of the current study. Interestingly, TON tended to decrease during the first several years of the trend period at several additional sites in the current study, then shifted to an increasing pattern around 1995 to 2000. This pattern was observed even at sites where a significant upward trend was ultimately selected for the entire trend period of 1989-2013. The regional consistency suggested these trends were influenced by factors that affected the entire study area.

Atmospheric deposition is one factor that may have contributed to the observed trends in TON. Globally, emissions of anthropogenic nitrogen increased following the mid-1900s as fossil-fuel combustion and intensive agriculture accelerated (Galloway and Cowling, 2002; Liu and others, 2013). Oxidized forms of nitrogen (nitrous oxide and nitrite), which are attributed primarily to combustion of fossil fuels, formerly dominated emissions in the United States. As a result of successful regulatory controls, emissions of oxidized nitrogen fractions have declined during the last 20 years; however, emissions of reduced forms of nitrogen (ammonia and ammonium) have increased and now dominate wet deposition. Increases in atmospheric ammonia have been attributed to increases in regional livestock production, nitrogen fertilizer application, and use of emission-control devices that convert oxidized forms of nitrogen to reduced forms ( $\mathrm{Li}$ and others, 2016). Nitrogen deposition has also increased outside of the United States - in Western Europe and rapidly industrializing nations such as China (Liu and others, 2013). Organic forms of nitrogen are also present in the atmosphere, often bound with fine particulate matter (aerosols), but data for atmospheric organic nitrogen are limited (Holland and others, 2005; Cornell, 2011). Nutrient enrichment from deposition of organic nitrogen is not well understood, and more information is needed to support management decisions (Jickells and others, 2013; Samy and others, 2013).

Links between shifting nitrogen deposition and instream nitrogen concentrations have not been well documented. In the Triangle, concentrations of nitrate and ammonia generally trended down, while TON trended up. If increased ammonia is being deposited, it would likely be quickly converted to oxidized forms and (or) assimilated into the aquatic food web. Further research is clearly needed to better understand the mechanisms responsible for observed increases in TON concentrations.

Total nitrogen concentrations in the Triangle study area during 1989-2013 ranged from 0.11 to $31.7 \mathrm{mg} / \mathrm{L}$ as $\mathrm{N}$ among stream sites and from $<0.25$ to $3.4 \mathrm{mg} / \mathrm{L}$ among lake sites (table 5). Total nitrogen concentrations varied widely among stream sites and were higher in New Hope Creek (site S7), Northeast Creek (site S8), and Morgan Creek near Farrington (site S10) than at other stream sites (table 6). In contrast, concentrations were relatively similar among lake sites, with medians ranging from 0.61 to $1.1 \mathrm{mg} / \mathrm{L}$ (table 7).

Because trends among inorganic and organic nitrogen fractions often diverged at sites, trends in total nitrogen were complex (table 8; fig. 17). During 1989-2013, total nitrogen did not change significantly at six sites. A statistically significant, but small, upward trend was observed at University Lake (site L5). Significant, downward trends were noted at Eno River near Durham (site S2) and Little River Reservoir (site L1). The most pronounced decrease in total nitrogen was a step trend at Northeast Creek (site S8), where total nitrogen decreased by 61.0 percent $(4.19 \mathrm{mg} / \mathrm{L})$ after July 2005 . This decrease was largely driven by the reduction in nitrate that occurred when nitrogen removal was implemented at the upstream WWTP. Total nitrogen concentrations decreased significantly at Haw River below Jordan dam (site S12) during the early period (1989-2000), but increased significantly at White Oak Creek (site S11) during the late period (2002 to 2013). Both of these trends, although statistically significant, accounted for relatively small changes in concentration. Oelsner and others (2017) also reported decreasing trends in total nitrogen for the Eno River near Durham (site S2) and New Hope Creek (site S7) during 1992-2012, in agreement with the current study. Although they noted a significant increase in total nitrogen for the Eno River at Hillsborough (site S1), the current study found a nonsignificant upward trend for the same site.

At nine sites, 2-period trend models best fit the total nitrogen data, indicating that trends shifted in direction and (or) rate of change during the trend period. Total nitrogen decreased at Morgan Creek near White Cross (site S9) during both the early and late periods, with annual median concentrations decreasing from 1.27 to $0.55 \mathrm{mg} / \mathrm{L}$. Site S9 was the only site where all nitrogen fractions decreased significantly during the trend period. At five sites (S5, S7, S13, L2, and L3), total nitrogen trended downward during 1989-2001, then upward from 2002 to 2013. At three sites (S10, L6, and L7), total nitrogen trended upward during 1989-2001, then decreased from 2002 to 2013. Most of these trends were small in terms of actual concentration changes. However, the 2-period trends at New Hope Creek (site S7) and Morgan Creek near Farrington (site S10) were more substantial and were largely attributable to underlying trends in nitrate, similar to the pattern observed at site S8.

At many sites where 2-period trend models were selected for total nitrogen, annual median concentrations were similar at the beginning (circa 1989) and end (2013) of the trend period. A simplistic 1-period trend analysis might have led to the misleading conclusion that there was no change over time. Trends tended to change in direction and magnitude over time; therefore, one should not assume that uniform or monotonic trends will adequately describe water quality. In fact, such oscillations are evidence of the highly dynamic nature of nitrogen cycling. Furthermore, analysis of trends in total nitrogen alone would not have reflected the complex and underlying trends among the various nitrogen fractions. 


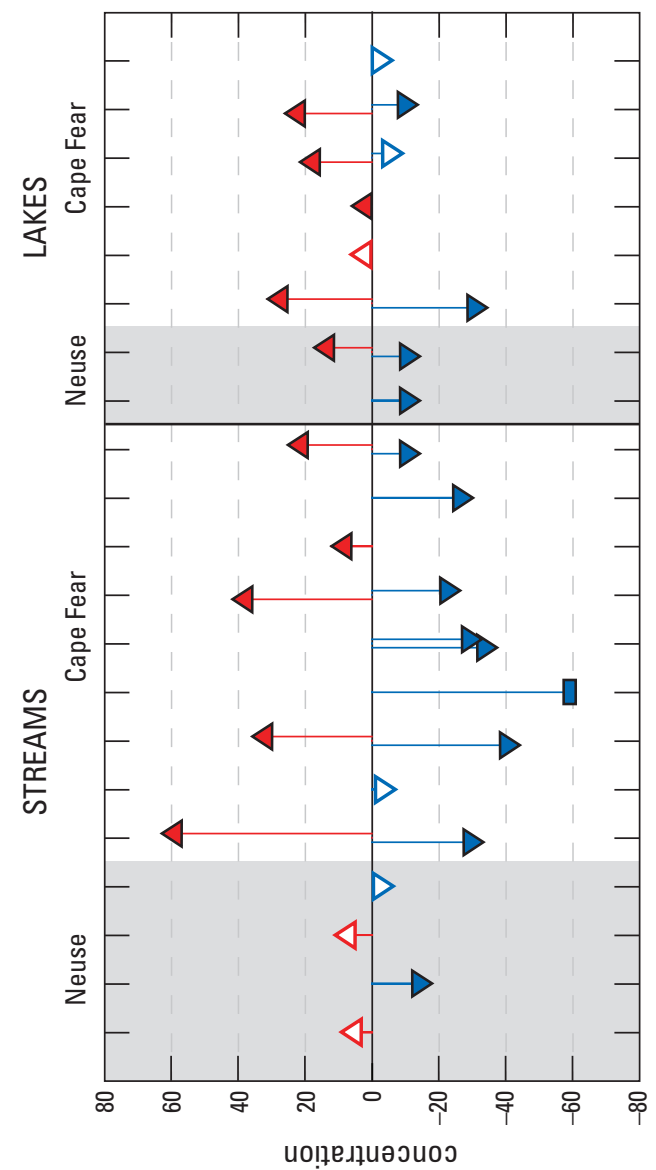

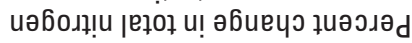
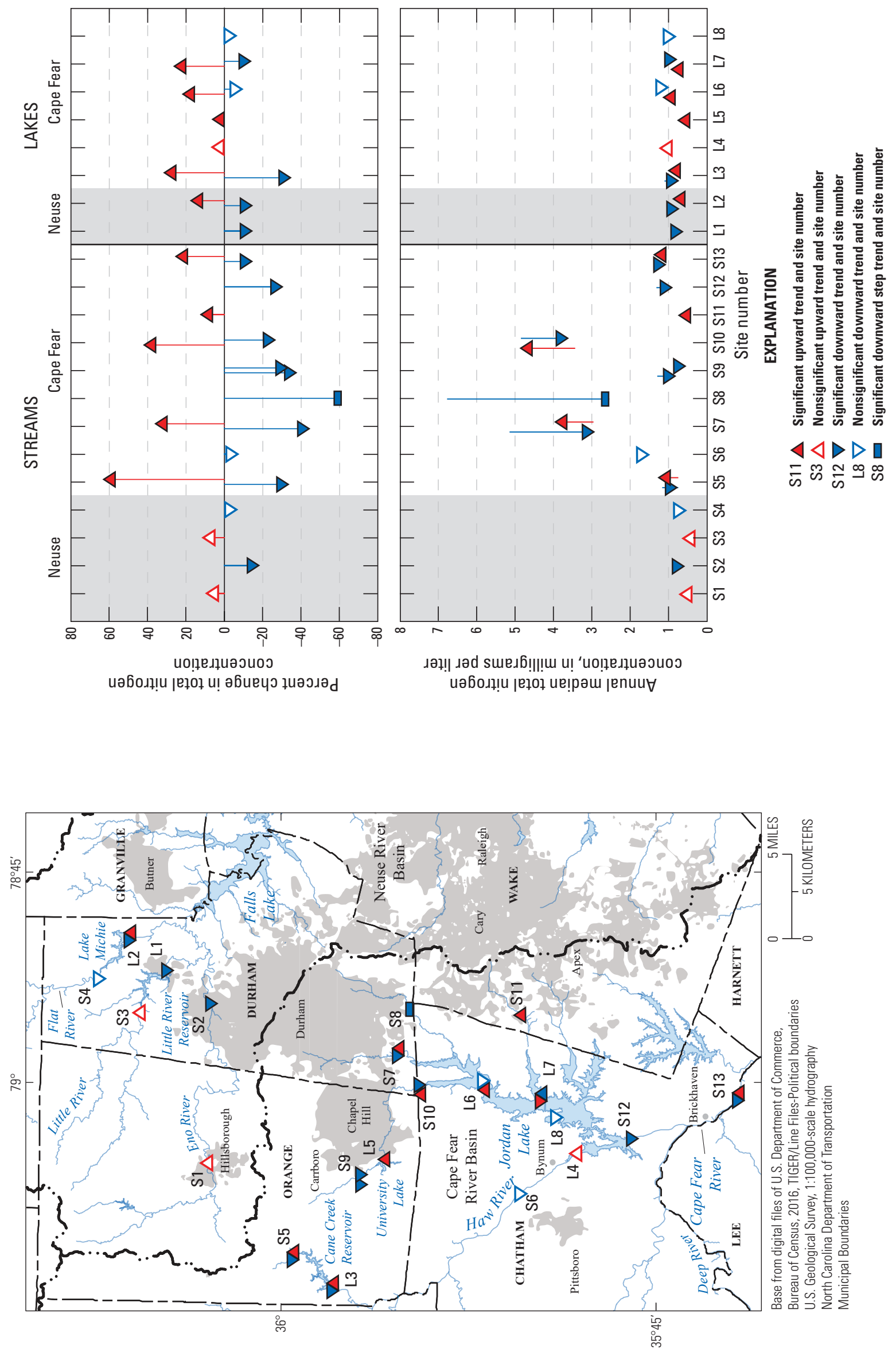

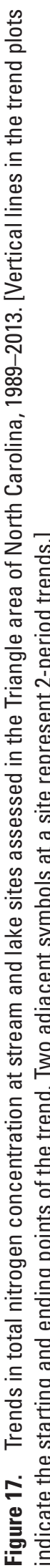


Like nitrogen, phosphorus occurs in water in several forms. Total phosphorus encompasses both inorganic and organic, and dissolved and particulate fractions. Sources of phosphorus in watersheds include decomposition of organic matter, human and animal waste, fertilizer, and soil runoff. In lakes, internal loading from sediment is another source of phosphorus. Excessive levels of phosphorus contribute to accelerated eutrophication, harmful algal blooms, and oxygen depletion. Water-quality standards for phosphorus currently have not been established in North Carolina but are under development.

At Triangle area sites, concentrations of total phosphorus were generally lower in lakes than in their upstream tributaries. Median concentrations among stream sites ranged from 0.030 to $0.280 \mathrm{mg} / \mathrm{L}$ as $\mathrm{P}$, and a maximum concentration of $4.10 \mathrm{mg} / \mathrm{L}$ was measured at New Hope Creek (site S7; table 6). Among lake sites, median concentrations ranged from 0.029 to $0.080 \mathrm{mg} / \mathrm{L}$ and were highest at Jordan Lake near Hanks Chapel (site L4) and Jordan Lake at Buoy 12 (site L6). The maximum lake concentration of $0.300 \mathrm{mg} / \mathrm{L}$ was measured at Jordan Lake at Buoy 12 (site L6; table 7). Stream and lake sites in the Neuse River Basin generally had lower concentrations of total phosphorus than most sites in the Cape Fear River Basin.

One-period trends in total phosphorus varied among sites in the study area (table 8; fig. 18). A statistically significant, upward trend in total phosphorus concentrations was noted at Jordan Lake near Hanks Chapel (site L4) and Jordan Lake at Bells Landing (site L8) during 1991-2013; upward but nonsignificant trends were noted at sites $\mathrm{S} 3$ and L5 during 1989-2013 and at site L6 during 1993-2013. The upward trend at site L4 represented a 48.6 percent increase, with annual median concentrations increasing from 0.064 to $0.094 \mathrm{mg} / \mathrm{L}$. It is of note that total phosphorus also increased by a substantial 57.8 percent at Jordan Lake at Farrington (site L6) during 1993-2013, from an annual median of 0.055 to $0.086 \mathrm{mg} / \mathrm{L}$; however, this trend was not statistically significant. Statistically significant downward trends during 1989-2013 were observed at Eno River near Durham, Flat River at Bahama, and Northeast Creek (sites S2, S4, and S8). Nonsignificant downward trends were noted at sites S10, L1, and L3 during 1989-2013, and at site S1 during 1990-2013. Oelsner and others (2017) previously reported downward trends in total phosphorus for sites S2 and S7 during 1992-2012, in agreement with the current study.

Trends for shorter periods varied considerably from site to site. Total phosphorus concentrations decreased significantly at Haw River below Jordan dam (site S12) during 1989-2000. At Haw River near Bynum (site S6) and Morgan Creek near White Cross (site S9), concentrations trended downward during both early and late periods but at different rates of change (table 8). At New Hope Creek (site S7), total phosphorus concentrations decreased from $0.397 \mathrm{mg} / \mathrm{L}$ in 1989 to $0.225 \mathrm{mg} / \mathrm{L}$ in 2001 (44.8 percent), which was the largest magnitude change observed during this study, followed by no significant trend during 2002-13. Total phosphorus concentrations increased significantly at White Oak Creek (site S11) during 2002-13, with annual medians rising from 0.045 to $0.068 \mathrm{mg} / \mathrm{L}$. Significant uptrends for four more sites were noted during either the early or late period (site S5, 2002-13; site S13, 1989-2001; site L2, 2002-13; site L7, 1991-2001) and were offset by similar downtrends during the corresponding period; consequently, annual median concentrations for those sites in 2013 were similar to values at the beginning of the study period. Oelsner and others (2017) previously reported significant downtrends in total phosphorus during 1992-2012 at sites S2 and S7, which generally agreed with results from the current study; however, they reported significant uptrends in total phosphorus at sites S1 and S4 during 2002-12, which were not supported by results from the current study. The current study included data from 2013, which may help account for the different trend results.

Some of the statistically significant downtrends at stream sites involved very small changes in total phosphorus concentration; however, annual median concentrations decreased more than $0.100 \mathrm{mg} / \mathrm{L}$ at four sites, including Haw River near Bynum (S6), New Hope Creek (S7), Northeast Creek (S8), and Morgan Creek near White Cross (S9). Three of these sites (S6, S7, and S8) have substantial inputs of treated municipal wastewater. Childress and Bathala (1997) previously analyzed water-quality trends in the Triangle area during 1983-95. They concluded that total phosphorus concentrations in all study streams showed a step-trend decrease after 1988, coinciding with the adoption of a statewide phosphate-detergent ban and increased phosphorus-removal practices at municipal wastewater-treatment facilities. The current study showed that total phosphorus continued to decline at sites S6, S7, and S8 through 2013 despite additional development and population growth in the watersheds; however, annual median concentrations in 2013 remained higher than at other sites. The significant decreases in total phosphorus and all nitrogen fractions at Morgan Creek near White Cross (site S9) may have resulted from improved land-management practices, including the closure of a dairy operation, restoration of riparian buffers, and livestock exclusion fencing, in this relatively undeveloped watershed (Ruth Rouse, Orange Water and Sewer Authority, written commun., February 27, 2018).

The upward trend in total phosphorus at Jordan Lake near Hanks Chapel (site L4) might appear to contradict the decreasing trend observed upstream at site S6, although it is interesting that the 2013 annual median concentrations at the two sites were in close agreement. Spruill and others (2006) previously noted that total phosphorus concentrations at Haw River near Bynum (site S6) decreased significantly during the period 1981-2004 and attributed this trend to loss of cropland, improved land-management practices, adoption of stringent wastewater-treatment practices in the watershed, and the statewide phosphate-detergent ban.

Total organic carbon provides an estimate of the amount of organic matter in water and, thus, is an important indicator of water quality for drinking-water suppliers. Elevated levels of total organic carbon in source water have been associated 

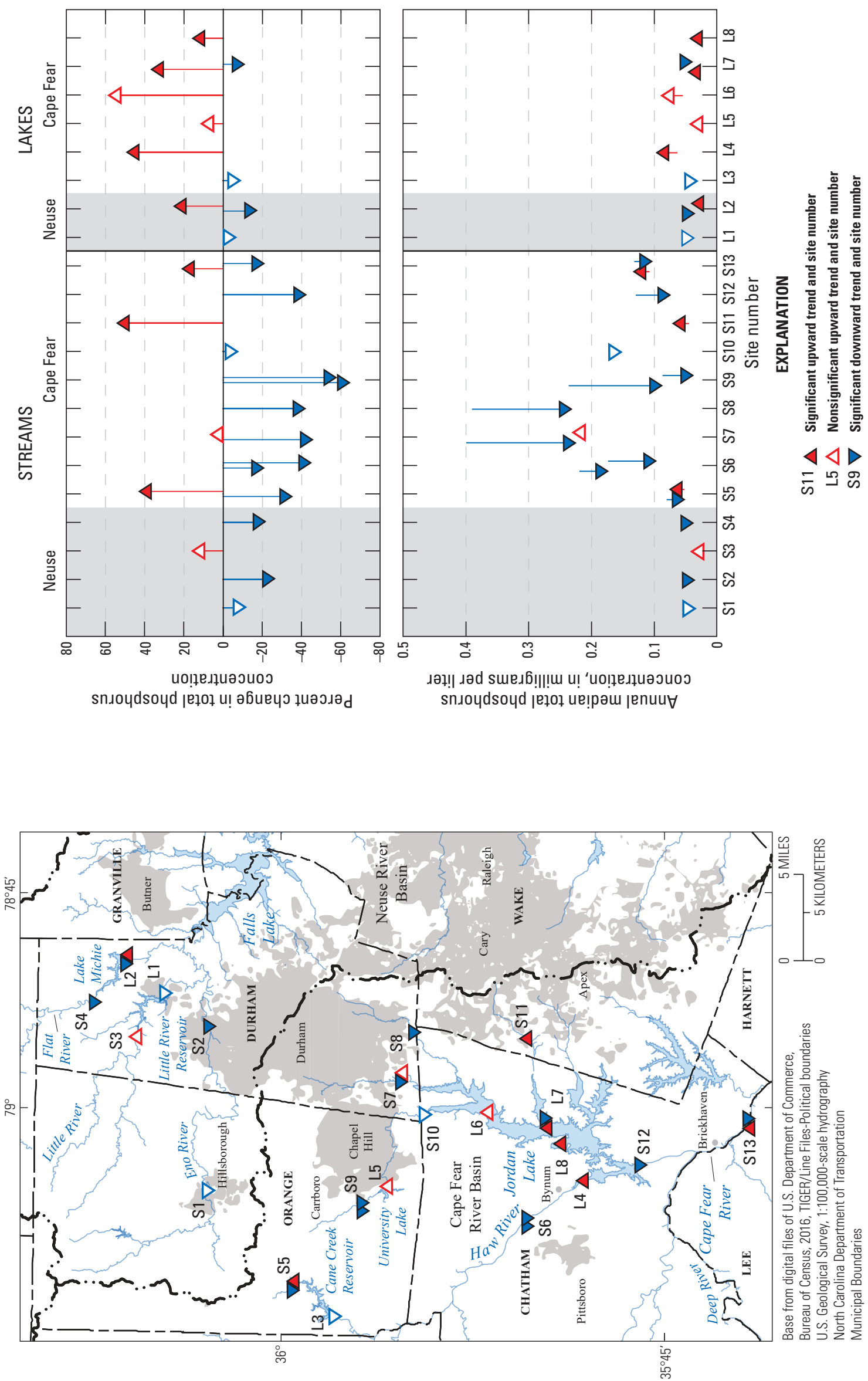
with increased formation of disinfection by-products during water treatment and with bacterial regrowth in water-

distribution systems. Organic carbon in water originates from natural organic matter and synthetic sources.

Total organic carbon data were available for five stream sites and eight lake sites in the study area. Concentrations ranged from 0.8 to $58.0 \mathrm{mg} / \mathrm{L}$ at the stream sites (table 6) and from 2.1 to $17.0 \mathrm{mg} / \mathrm{L}$ at the lake sites (table 7). White Oak Creek (site S11; $11.1 \mathrm{mg} / \mathrm{L}$ ) and Jordan Lake at Buoy 12 (site L6; $10.6 \mathrm{mg} / \mathrm{L}$ ) had the highest median concentrations among stream and lake sites, respectively.

Trends for total organic carbon were analyzed for the 13 sites for which data were available (table 8; fig. 19). All but two sites had sufficient data to evaluate both the 1- and 2-period trend models. Trends could be evaluated only for the late period (2002-13) at White Oak Creek (site S11) and only for the early period (1989-2001) at Cape Fear River near Brickhaven (site S13). One-trend models indicated that total organic carbon increased significantly at three sites from 1989 to 2013, including Eno River at Hillsborough (S1), Lake Michie (L2), and University Lake (L5) and nonsignificantly at four additional sites (S5, L1, L3, and L7). The maximum percent increase was observed at Eno River at Hillsborough (site $\mathrm{S} 1 ; 19.8$ percent), and the maximum concentration increase was observed at University Lake (site L5; $1.3 \mathrm{mg} / \mathrm{L}$ ). The uptrend at site $\mathrm{S} 1$ was corroborated in a national assessment of stream water-quality trends for the period 1992-2012 (Oelsner and others, 2017).

A nonsignificant downtrend was observed at White Oak Creek (site S11) during the late period, and a nonsignificant uptrend was noted at the Cape Fear River (site S13) during the early period. Trends at the four remaining sites were best described by 2-period trend models that included both uptrends and downtrends. The downward trend at Morgan Creek near White Cross (site S9) during 2002-13 represented the greatest percent decrease (21.1 percent). Annual median concentrations decreased $1.1 \mathrm{mg} / \mathrm{L}$ from 2002 to 2013 at both site S9 and Jordan Lake near Hanks Chapel (site L4).

\section{Total Suspended Solids and Suspended Sediment in Streams}

Total suspended solids and suspended sediment were measured in study area streams. Both constituents provide information on the amount of solid-phase material suspended in the water column, but the results are not interchangeable because of differences in sampling technique and laboratory analytical methods (Gray and others, 2000). Total suspended solids data generally demonstrate a negative or low bias but may still be useful for trend comparisons.

Total suspended solids were measured by the NCDEQ, UCFRBA, and MCFRBA at nine sites, but trends were not analyzed at two of these sites (S3 and S6) because more than 20 percent of the values were censored (tables 6,9). Sufficient data were available to evaluate both the 1- and 2-period trend models at the remaining seven sites (table 9; fig. 20). Total suspended solids decreased significantly from 1989 to 2013 at three sites, including Flat River at Bahama (S4), New Hope Creek (S7), and Northeast Creek (S8). A nonsignificant downtrend was observed at the Eno River near Durham (site S2). The most pronounced downtrend (42.3 percent, with annual median concentrations declining from 23 to $10 \mathrm{mg} / \mathrm{L}$ ) was associated with a step trend at Northeast Creek (site S8) that began July 2005. It is not known whether the decrease in total suspended solids was directly related to upgrades at the upstream wastewater-treatment facility or if other factors were involved. Downtrends occurred at sites S7 and S8 despite substantial increases in population density, loss of forested land, and gains in developed area in the watersheds (tables 2 and 3 ).

Two-period trend tests revealed shifts in trend direction and (or) magnitude at the three remaining sites (S10, S12, and S13). The overall magnitude of change at these sites was relatively small - annual median concentrations at the beginning and end of the trend period changed by only 3 or $4 \mathrm{mg} / \mathrm{L}$.

Suspended-sediment samples were collected and analyzed by the USGS at most stream sites in the study area; however, only six sites had sufficient data for analyzing trends (table 9; fig. 21). Suspended-sediment concentrations decreased significantly during the entire trend period at Eno River at Hillsborough (site S1; 44.7 percent) and Flat River (site S4; 56.7 percent), equivalent to reductions in annual median concentrations of $5 \mathrm{mg} / \mathrm{L}$ and $9 \mathrm{mg} / \mathrm{L}$, respectively. Reasons for the downtrends at these sites are uncertain but could relate to improved land-management practices. In addition, suspended-sediment concentrations at site S1 may have been influenced by the construction of a new reservoir upstream (West Fork Eno Reservoir) in 2000. Although there was little overall change in percent agricultural land cover in the Flat River watershed during the trend period (table 3), this watershed has experienced a loss of cropland and an increase in lands used for pasture and hay, which typically have lower rates of soil loss. Suspended-sediment concentrations also decreased significantly (45.4 percent; $10 \mathrm{mg} / \mathrm{L}$ ) at Cape Fear River near Brickhaven (site S13) during 1989-2001. A downward trend noted at Morgan Creek near White Cross (site S9) during 2002-13 was statistically significant, but was associated with a negligible change in concentration $(2 \mathrm{mg} / \mathrm{L})$. The only stream site with a significant, increasing trend was White Oak Creek (S11) for the late period 2002-13 (72.6 percent; $8 \mathrm{mg} / \mathrm{L}$ ). The watershed for this site had the highest increases in population density (table 2) and amount of developed land (table 3 ) of all the watersheds in the study.

Comparison of trends for total suspended solids and suspended sediment was possible for two stream sites. At Flat River (site S4), trends for both constituents were computed for the 1989-2011 period. Significant downtrends were observed for both total suspended solids and suspended sediment. At Cape Fear River near Brickhaven (site S13), significant downward trends were observed for total suspended solids trends during 1992-2001 and for suspended sediment during 

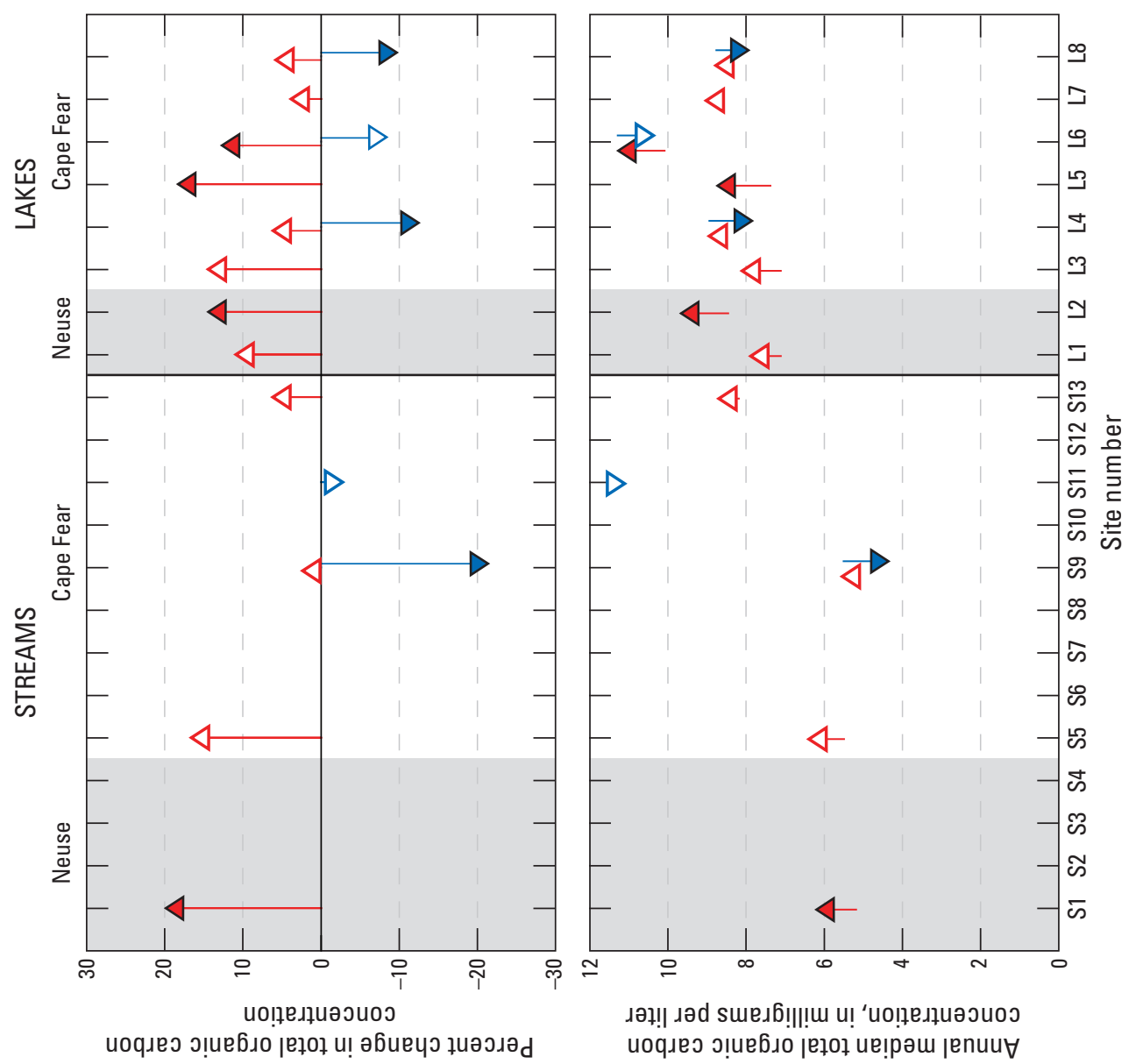

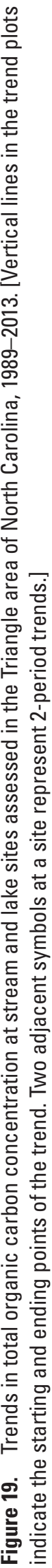

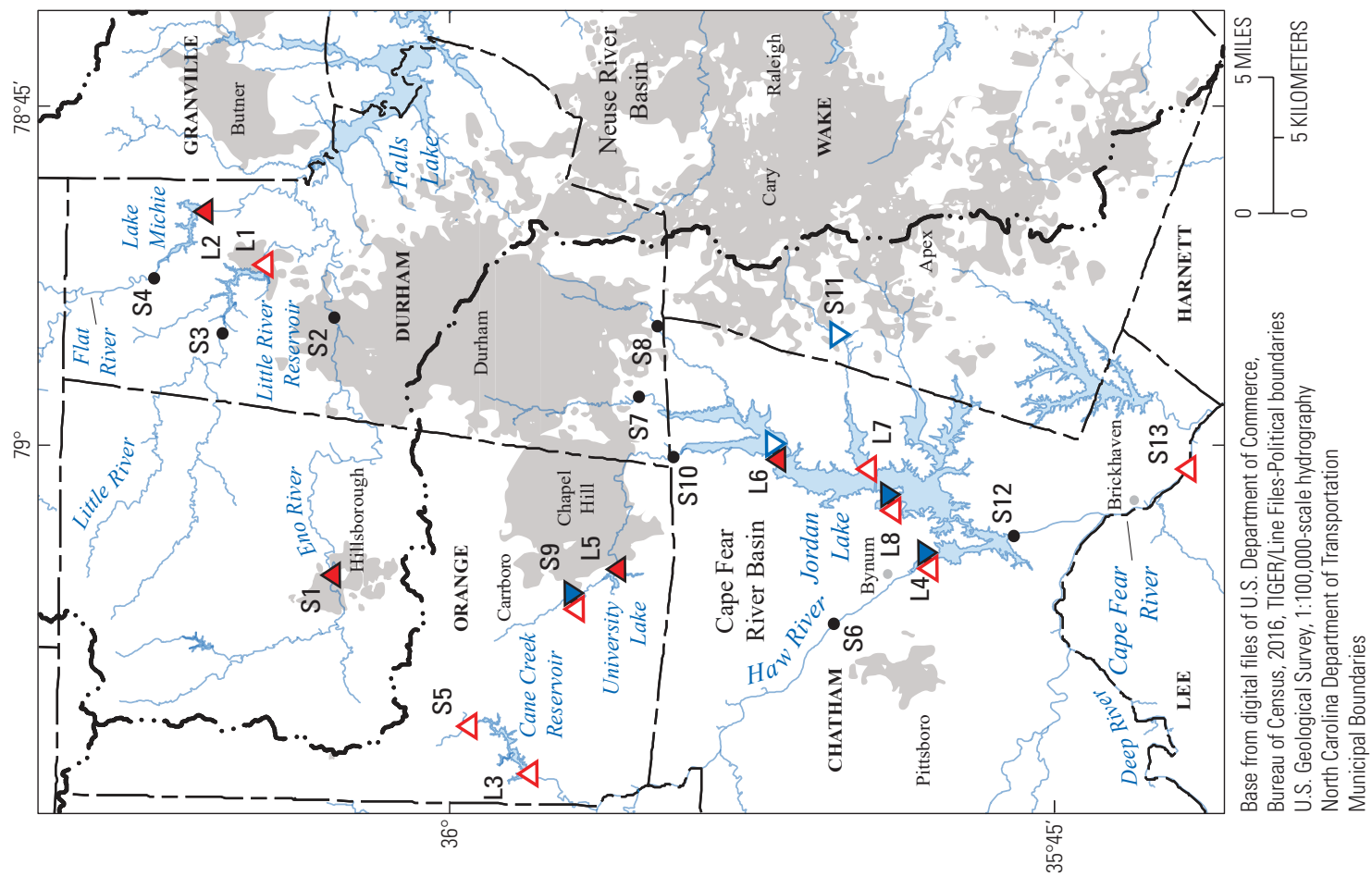


Table 9. Summary of trend results based on data collected during 1989-2013 for total suspended solids and suspended sediment at stream sites assessed in the Triangle area of North Carolina.

[Bold red font indicates statistically significant (at p-value less than 0.05) upward trend results, and bold blue font indicates statistically significant downward trend results. Gray shading indicates no trend results are presented because more than 20 percent of the data were censored. Abbreviations: USGS, U.S. Geological Survey; NC, North Carolina; mg/L, milligram per liter; $<$, less than]

\begin{tabular}{|c|c|c|c|c|c|c|c|}
\hline $\begin{array}{l}\text { Map no. } \\
\text { (fig. 1) }\end{array}$ & USGS station name & $\begin{array}{l}\text { Best-fit trend } \\
\text { model }\end{array}$ & $\begin{array}{l}\text { Trend } \\
\text { period }\end{array}$ & $\begin{array}{l}\text { Percent } \\
\text { change }\end{array}$ & p-value & $\begin{array}{l}\text { Fitted annual } \\
\text { median } \\
\text { concentration } \\
\text { for first year } \\
\text { in period }\end{array}$ & $\begin{array}{l}\text { Fitted annual } \\
\text { median } \\
\text { concentration } \\
\text { for last year } \\
\text { in period }\end{array}$ \\
\hline \multicolumn{8}{|c|}{ Suspended solids (mg/L) } \\
\hline $\mathrm{S} 2$ & Eno River near Durham, NC & 1-period & 1989-2013 & -10.0 & 0.3055 & 12 & 7 \\
\hline $\mathrm{S} 3$ & $\begin{array}{l}\text { Little River at SR } 1461 \text { near Orange Fac- } \\
\text { tory, NC }\end{array}$ & none & $1989-2013$ & \multicolumn{2}{|c|}{ highly censored } & & \\
\hline S4 & Flat River at Bahama, NC & 1-period & 1989-2011 & -29.2 & 0.0045 & 9 & 7 \\
\hline S6 & Haw River near Bynum, NC & none & $1989-2013$ & \multicolumn{2}{|c|}{ highly censored } & & \\
\hline S7 & New Hope Creek near Blands, NC & 1-period & $1989-2013$ & -37.2 & $<0.0001$ & 25 & 16 \\
\hline $\mathrm{S} 8$ & $\begin{array}{l}\text { Northeast Creek at SR } 1100 \text { near Genlee, } \\
\text { NC }\end{array}$ & Step, July 2005 & $1992-2012$ & -42.3 & $<0.0001$ & 23 & 10 \\
\hline \multirow[t]{2}{*}{$\mathrm{S} 10$} & Morgan Creek near Farrington, NC & 2-period & 1989-2001 & -7.4 & 0.3107 & 12 & 11 \\
\hline & & & 2002-2013 & 38.0 & 0.0020 & 11 & 15 \\
\hline \multirow[t]{2}{*}{$\mathrm{S} 12$} & Haw River below B. Everett Jordan Dam & 2-period & $1989-2001$ & -8.8 & 0.2899 & 11 & 10 \\
\hline & near Moncure, NC & & $2002-2013$ & -30.5 & 0.0119 & 10 & 7 \\
\hline \multirow[t]{2}{*}{$\mathrm{S} 13$} & Cape Fear River at State Highway 42 & 2-period & $1992-2001$ & -30.5 & 0.0147 & 15 & 11 \\
\hline & near Brickhaven, NC & & $2002-2012$ & 4.8 & 0.3625 & 11 & 11 \\
\hline \multicolumn{8}{|c|}{ Suspended sediment (mg/L) } \\
\hline $\mathrm{S} 1$ & Eno River at Hillsborough, NC & 1-period & 1990-2013 & -44.7 & 0.0003 & 12 & 7 \\
\hline S4 & Flat River at Bahama, NC & 1-period & 1989-2011 & -56.7 & $<0.0001$ & 16 & 7 \\
\hline S5 & Cane Creek near Orange Grove, NC & 1-period & 1989-2013 & 3.9 & 0.8875 & 7 & 8 \\
\hline \multirow[t]{2}{*}{ S9 } & Morgan Creek near White Cross, NC & 2-period & 1989-2001 & 27.1 & 0.1582 & 6 & 7 \\
\hline & & & $2002-2013$ & -37.6 & 0.0270 & 7 & 5 \\
\hline $\mathrm{S} 11$ & $\begin{array}{l}\text { White Oak Creek at mouth near Green } \\
\text { Level, NC }\end{array}$ & Late period & 2002-2013 & 72.6 & 0.0002 & 11 & 19 \\
\hline $\mathrm{S} 13$ & $\begin{array}{l}\text { Cape Fear River at State Highway } 42 \\
\text { near Brickhaven, NC }\end{array}$ & Early period & 1989-2001 & -45.4 & 0.0005 & 22 & 12 \\
\hline
\end{tabular}



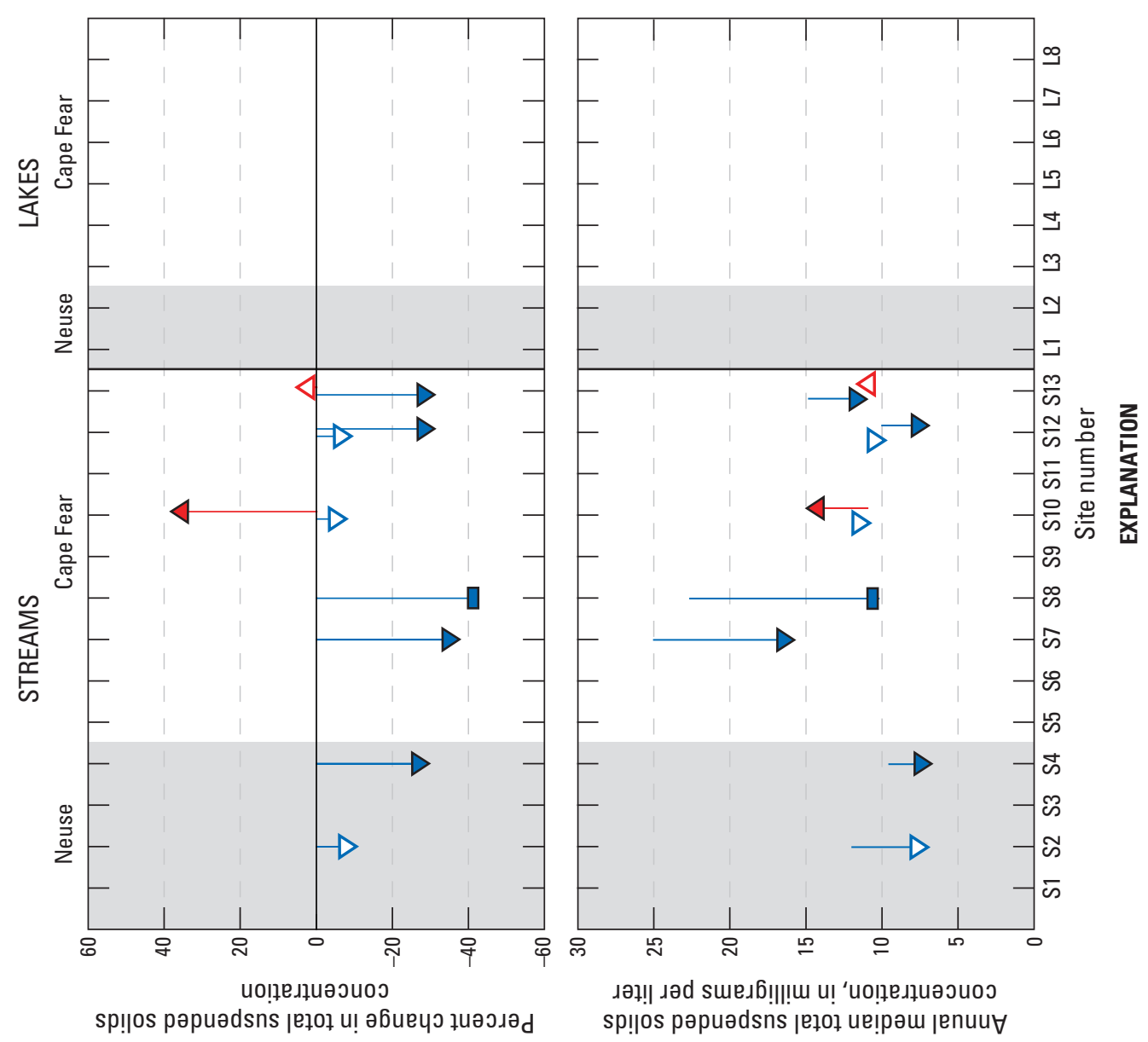

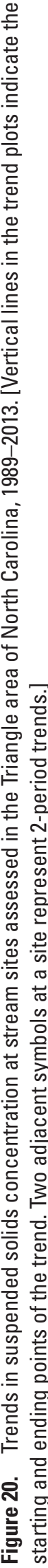

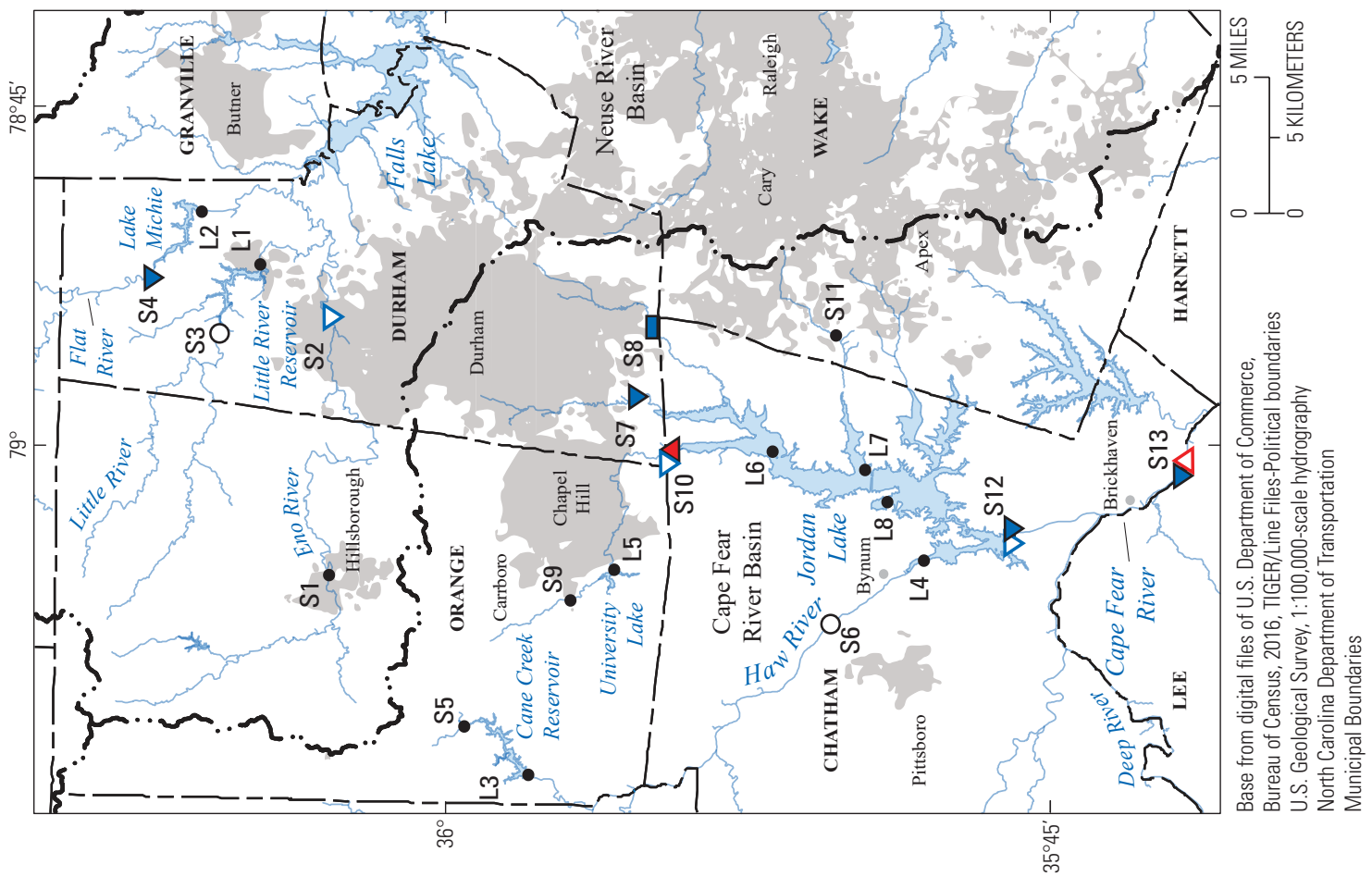



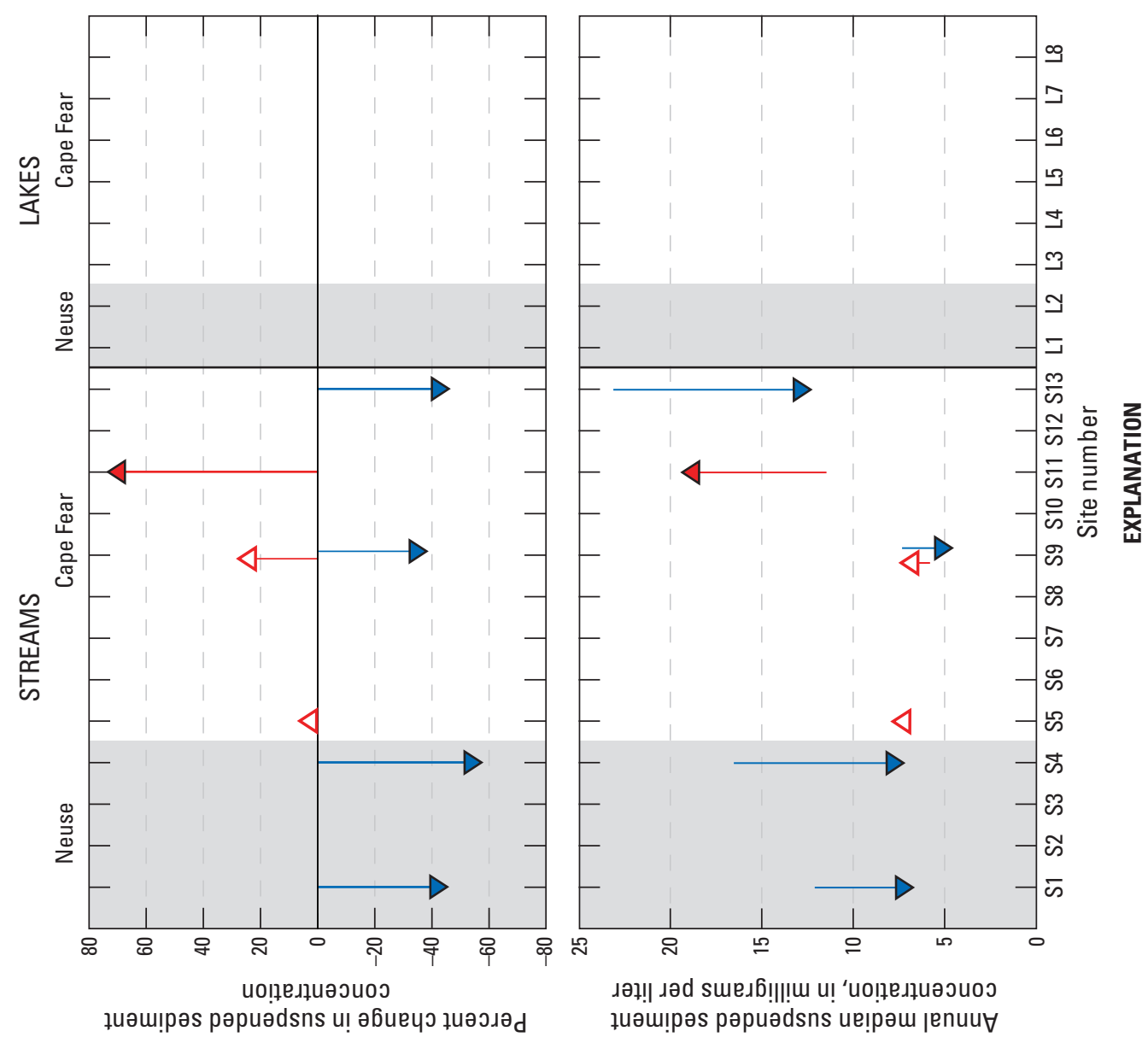

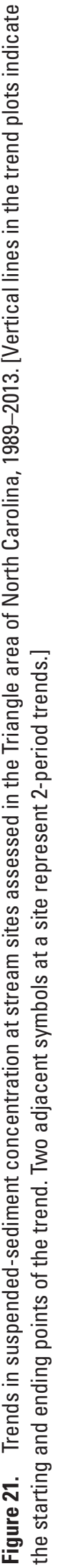

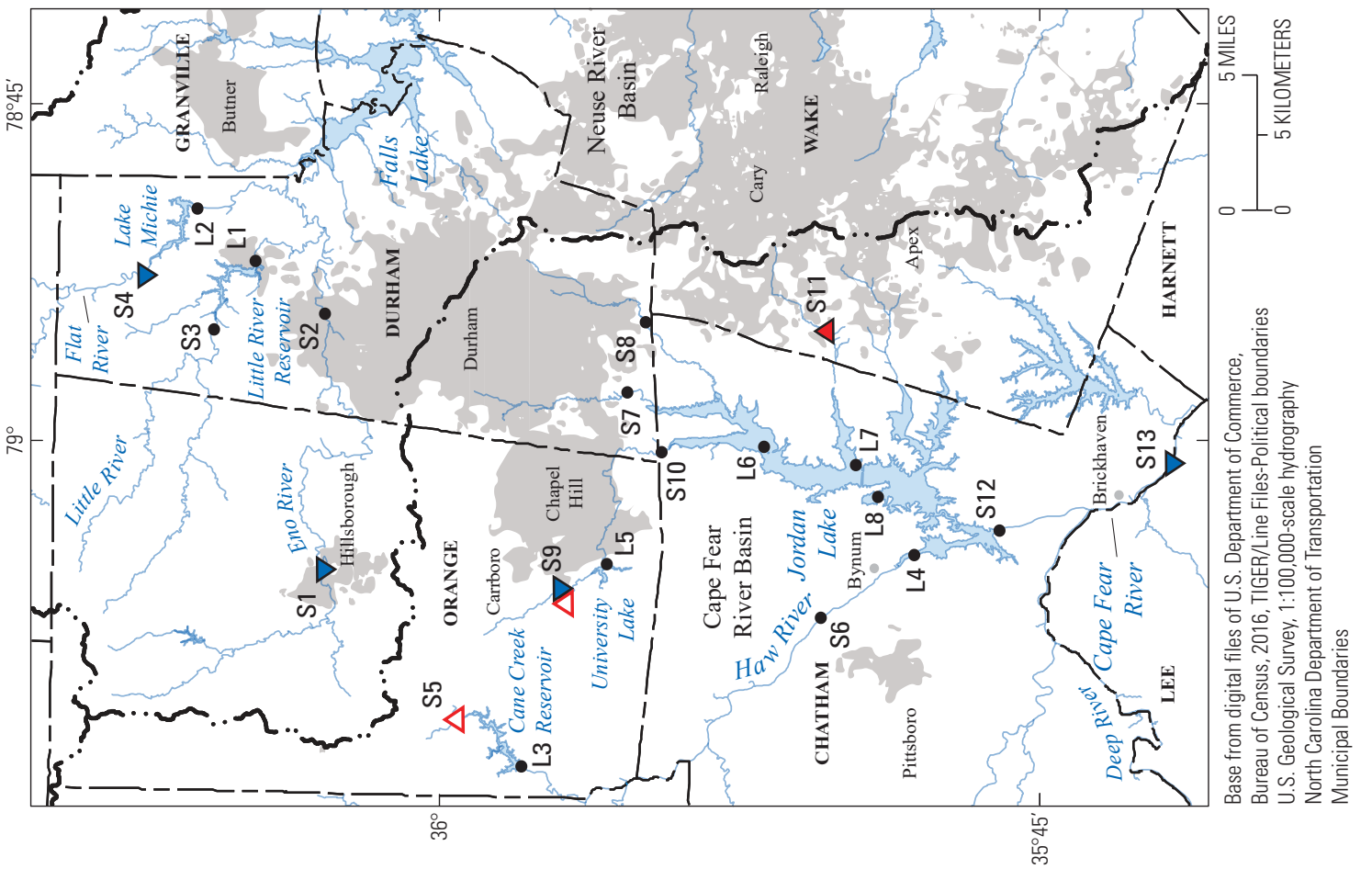


the early period 1989-2001. Therefore, trend directions for these two constituents were in agreement at both sites, although the trend magnitudes were higher for suspended sediment (table 9).

\section{Secchi Transparency and Chlorophyll a in Lakes}

Secchi transparency and chlorophyll $a$ were measured only at lake sites. All data included in the trend analysis were obtained from samples collected by the USGS. The USGS began measuring Secchi transparency in the study area in 1993; therefore, the trend-analysis period for this water-quality property is 1993 to 2013. Secchi transparency is a measure of water clarity and can be used to estimate the depth of the water column where sufficient light is available to support the growth of phytoplankton and (or) rooted aquatic plants. Secchi-depth measurements provide a useful indicator of lake productivity. Highly productive, or eutrophic, lakes tend to have shallower Secchi depths. In this study, median Secchi depths measured at lake sites ranged from $0.50 \mathrm{~m}$ at Jordan Lake at Buoy 12 (site L6) to $1.20 \mathrm{~m}$ at Cane Creek Reservoir (site L3; table 7).

Water clarity did not change significantly at University Lake (site L5) or Jordan Lake near Hanks Chapel (site L4) during the study period. Water clarity increased significantly at six lake sites during 1993-2013 (table 10; fig. 22), including Little River Reservoir (L1), Lake Michie (L2), Cane Creek Reservoir (L3), and three sites in the New Hope Creek arm of Jordan Lake (L6, L7, L8). Significant increases ranged from 24.8 to 65.6 percent, which corresponded to magnitudes of change ranging from 0.12 to $0.46 \mathrm{~m}$. The greatest increases in clarity were seen at Cane Creek Reservoir (site L3; $0.46 \mathrm{~m}$ ) and Little River Reservoir (site L1; $0.41 \mathrm{~m}$ ). Both of these reservoirs were constructed in 1988. Newly impounded reservoirs typically undergo a sequence of water-quality changes characterized by an initial surge of eutrophication followed by recovery and stabilization (Thornton and others, 1996). The initial surge of productivity is fueled by decaying organic matter from flooded vegetation and soils. The duration of this period depends on the amount of organic matter that was left in the flooded area, but typically lasts several years. It is likely that water clarity improved as these two reservoirs stabilized.

Chlorophyll $a$, the primary plant pigment active in photosynthesis, is useful as an indicator of algal biomass and, thus, lake productivity. Step-trend analysis compared concentrations for the periods before and after the change in chlorophyll $a$ laboratory methods that occurred on October 1, 2005. As anticipated, this change resulted in apparent increases in chlorophyll $a$ concentrations at all lake sites, ranging from 37.1 to 426 percent (table 10). The 1-period trend results (table 10; fig. 23) indicated that chlorophyll $a$ decreased significantly from 1992 to 2013 at three lake sites, Lake Michie (L2), University Lake (L5), and Jordan Lake at Buoy 12 (L6). Nonsignificant downward trends were noted at Little River Reservoir (site L1), Cane Creek Reservoir (site L3), and Jordan Lake near Hanks Chapel (site L4). Chlorophyll $a$ concentrations increased at Jordan Lake at Wilsonville (site L7) and Jordan Lake at Bells Landing (site L8), but these upward trends were not statistically significant.

It should be noted that chlorophyll $a$ concentrations vary seasonally, and annual median concentrations are not especially meaningful from an environmental standpoint. The computed annual median concentrations for 2013 incorporate effects of both the step and 1-period trends and are presented solely for the purpose of summarizing model-fitted concentrations at the beginning and end of the trend-analysis period. Given the highly variable nature of chlorophyll $a$ concentrations in lakes, trend results computed for these data should be interpreted broadly and with caution. It would be expected that decreasing trends in chlorophyll $a$ would be associated with increases in Secchi depth, and this inverse relation was observed at all lake sites except two Jordan Lake sites-L7 and L8 (figs. 22 and 23). 
Table 10. Summary of trend results based on data collected during 1992-2013 for Secchi transparency and chlorophyll a at lake sites assessed in the Triangle area of North Carolina.

[Bold red font indicates statistically significant (at p-value less than 0.05) upward trend results, and bold blue font indicates statistically significant downward trend results. Abbreviations: USGS, U.S. Geological Survey; NC, North Carolina; m, meter; <, less than; $\mu \mathrm{g} / \mathrm{L}$, microgram per liter]

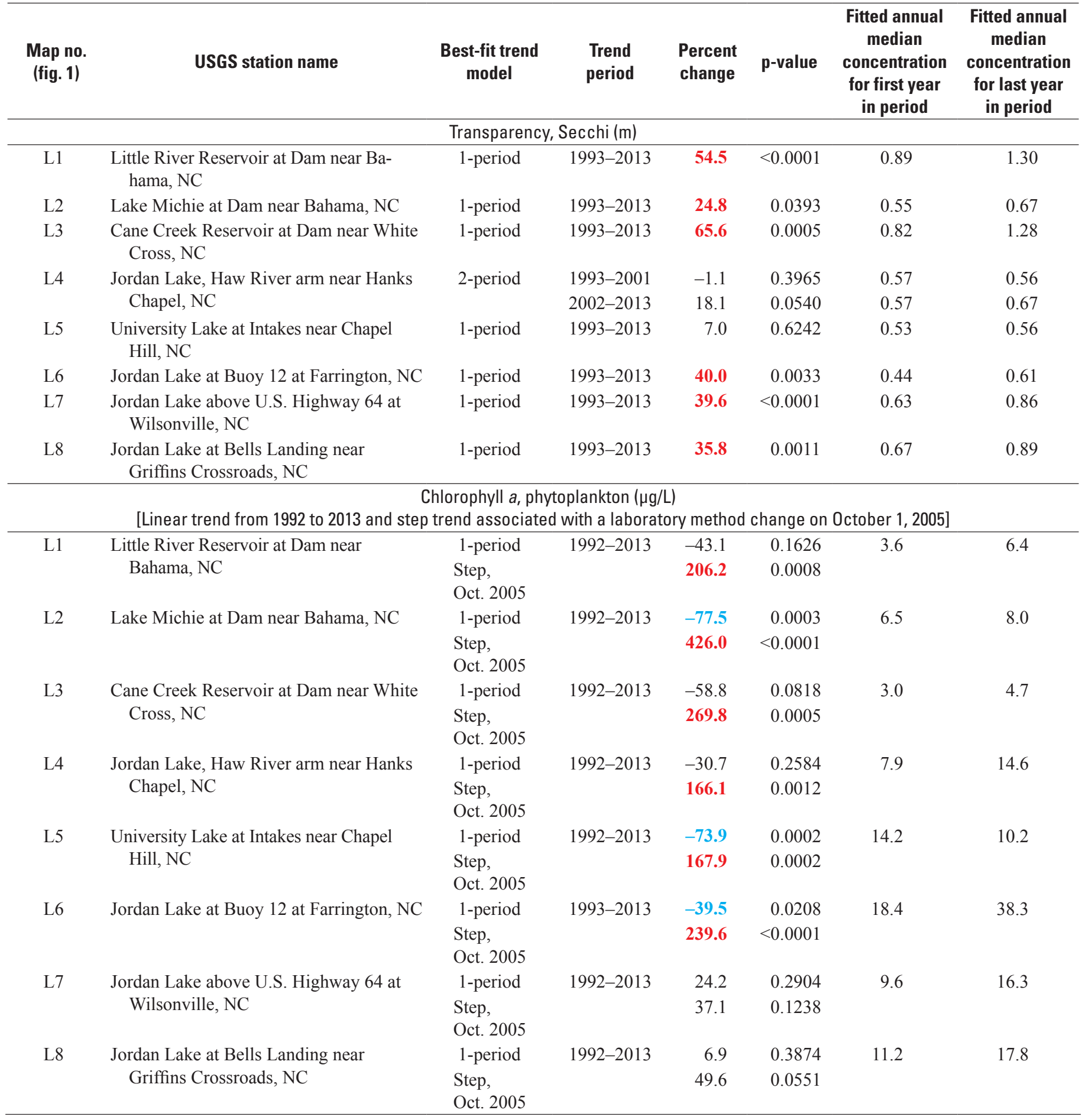



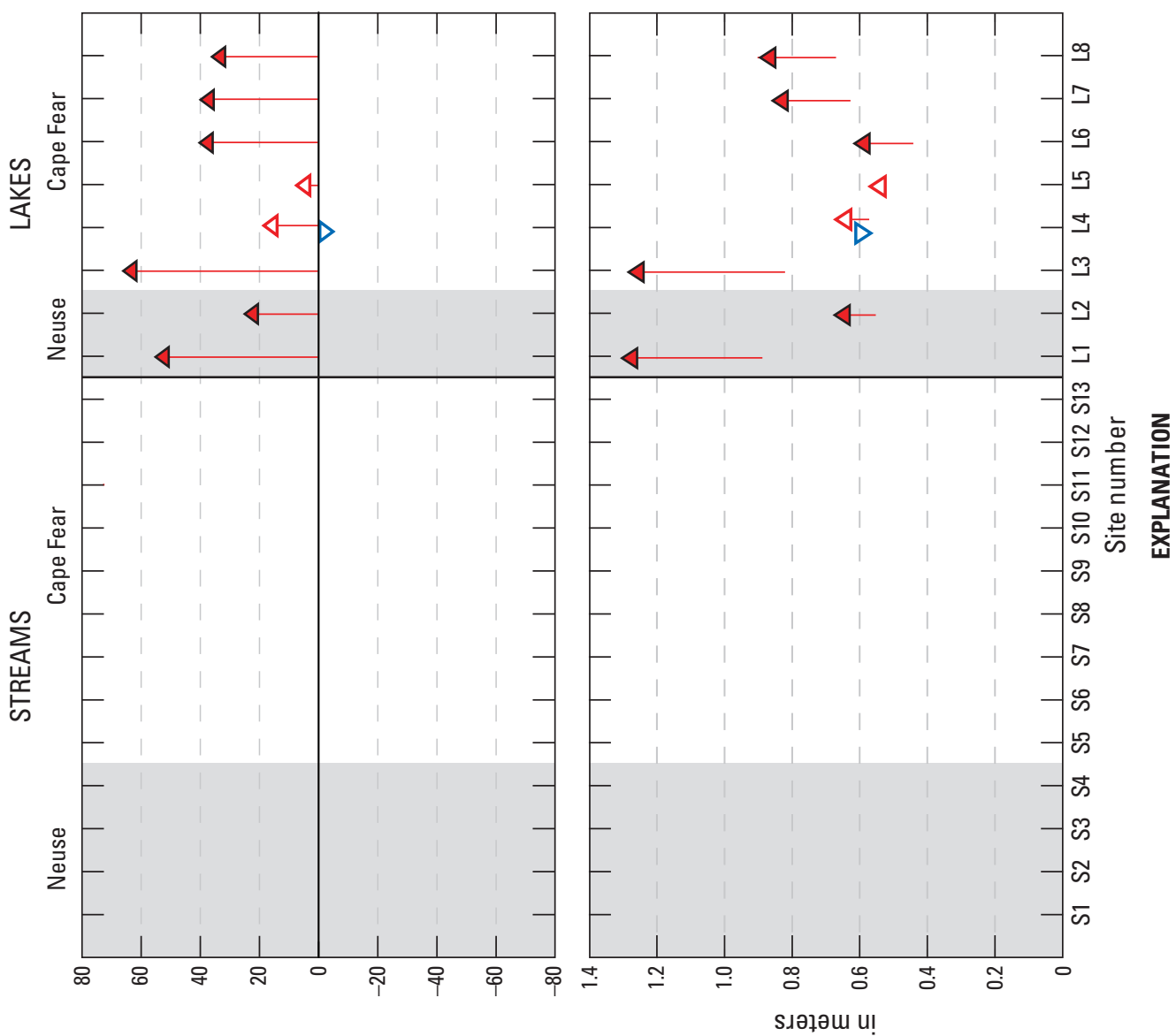

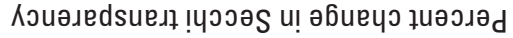

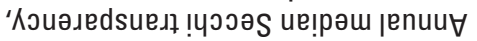

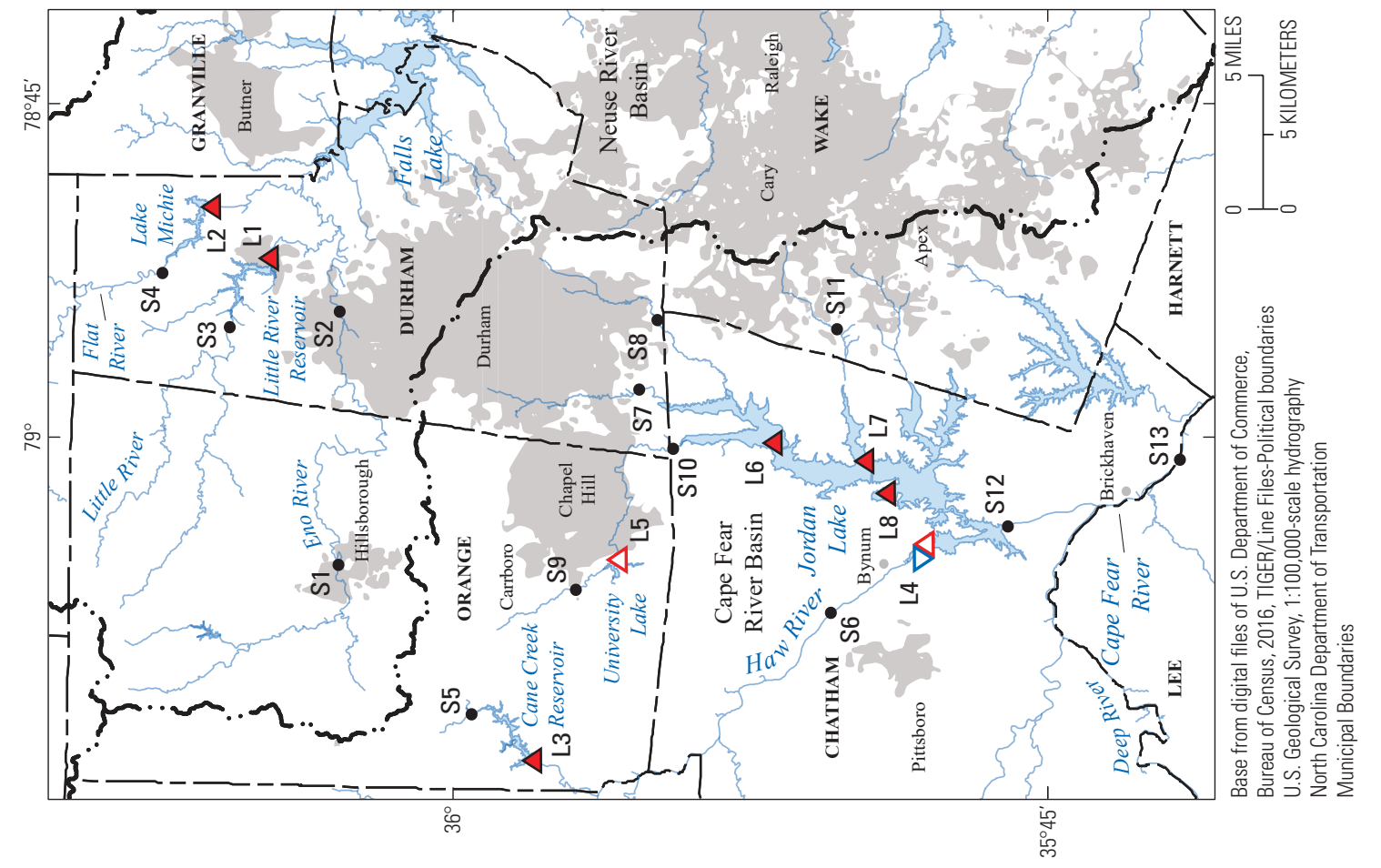

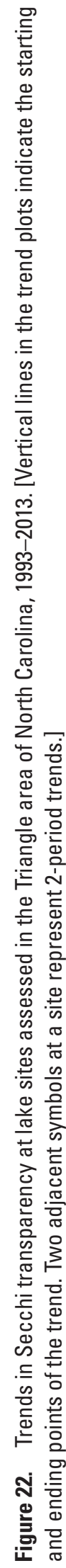




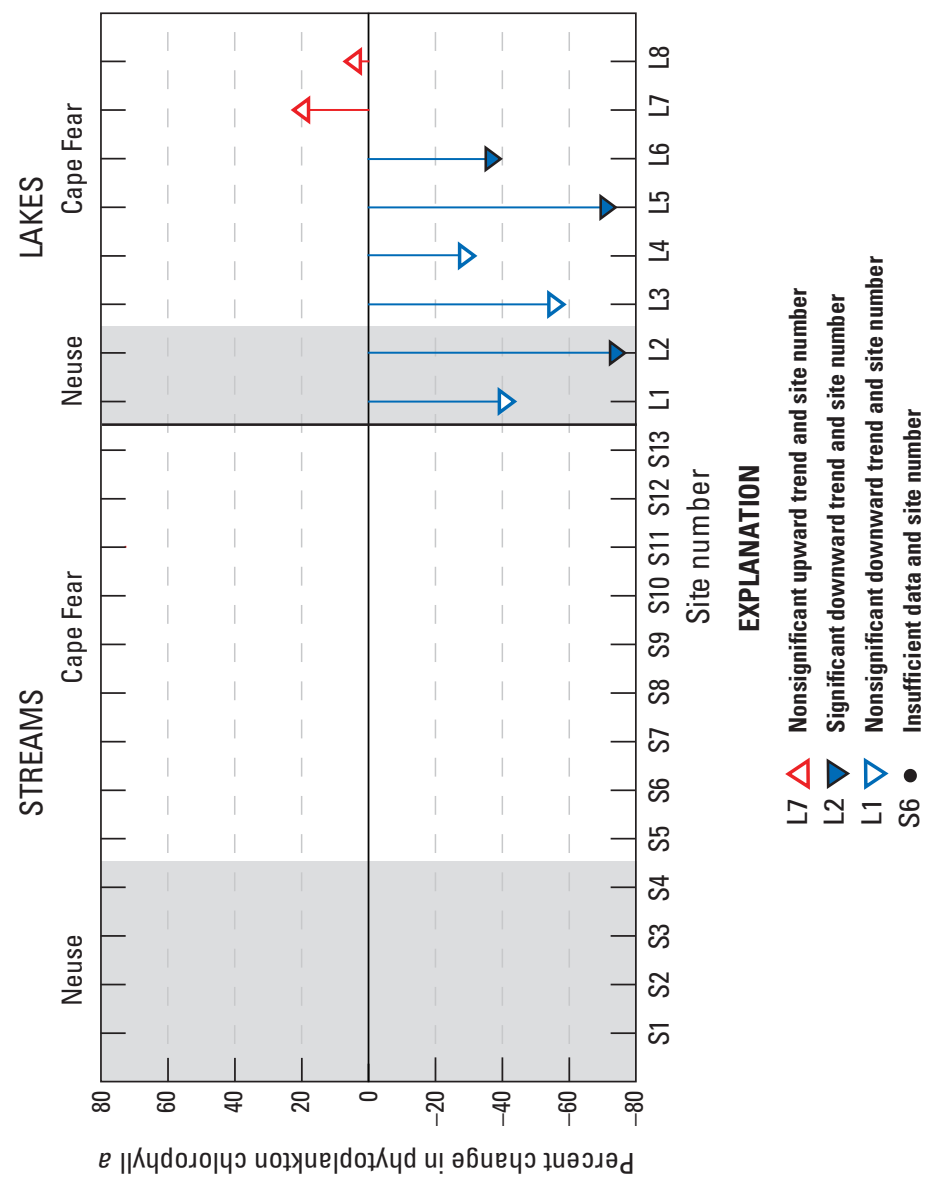

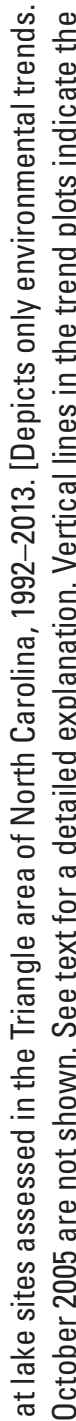

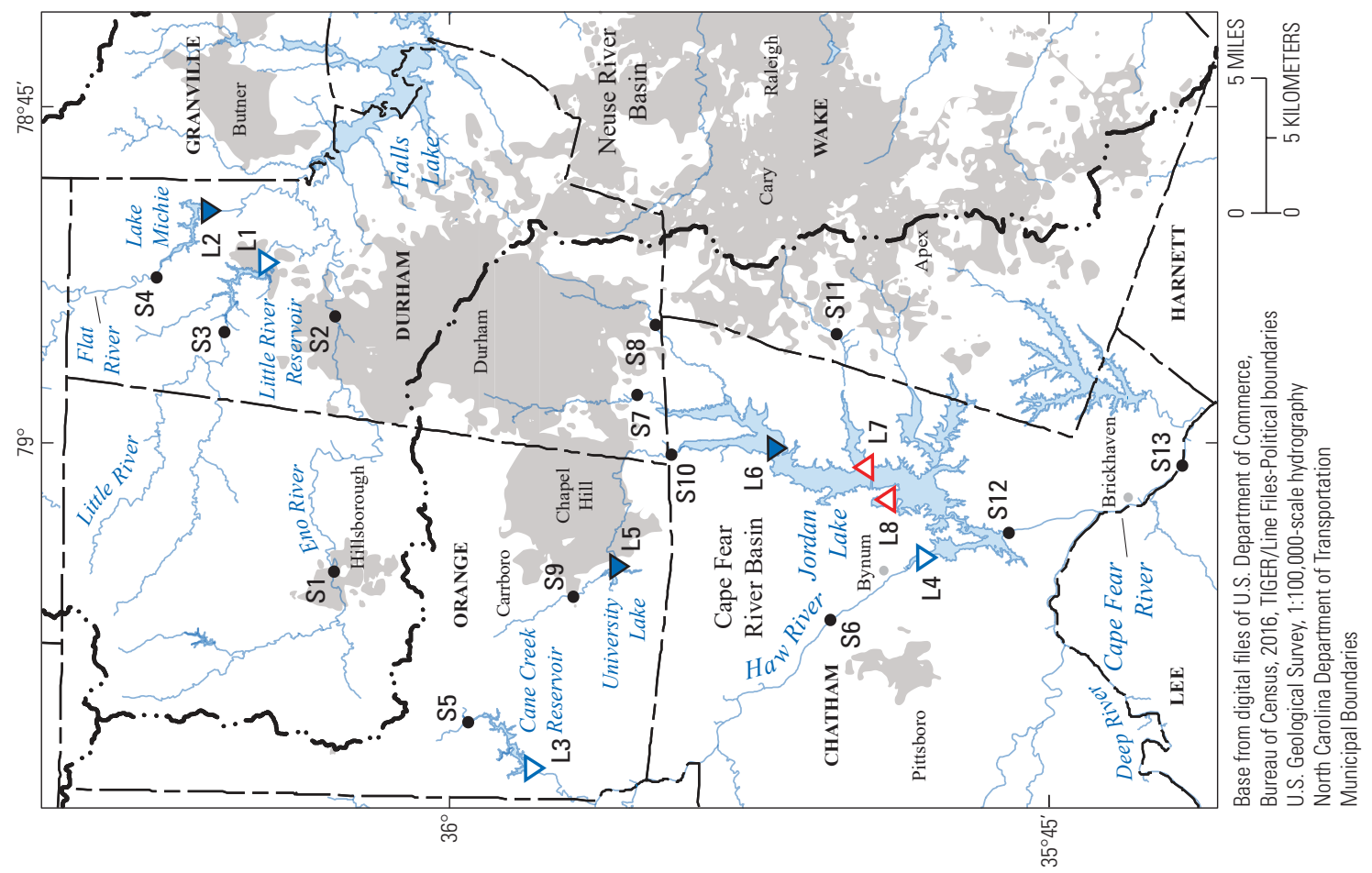

흐 .

䒿

仓ั

○े

일

층 는

흥 뚱

든 흥 형

든 즌

든

은

芒咅兽

들 흥

s c

ฮํㅓㅇ

눵

ฟ่ ปั

๑)

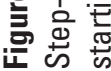




\section{Summary and Conclusions}

Lakes and their tributary streams are critical sources of public drinking water for residents of the Triangle area of North Carolina. This report provides an assessment of trends in streamflow and water-quality constituent concentrations at selected sites in the study area from 1989 through 2013. A statewide phosphate-detergent ban was adopted in 1988, and, since then, numerous additional nutrient-reduction and watersupply watershed protection measures have been put in place in the study area to address point-source and nonpoint sources of nutrients and other pollutants. In addition, population, urban development, and water-supply demands have continued to expand in the study area. Results from the current trend study are useful for understanding progress toward water-quality goals in the region and for understanding how water quality is responding to increased population, land-cover change, and hydrologic alteration.

Population density and percentage of developed lands increased in all study-site watersheds during the trend period, but intensity of growth varied considerably among watersheds. Overall, gains in developed lands were accounted for by losses in forested lands, with little change in percentages of agricultural land. Streamflow trended downward at several streamgaging sites, especially those with upstream withdrawals or small watersheds. Ongoing, continuous monitoring of streamflow is critical for documenting whether these changes are short-term fluctuations or long-term trends. One should note that flow at various Triangle area streams is influenced by upstream impoundments, inflows of treated municipal wastewater and urban runoff, and (or) water-supply withdrawals.

Across the study area, upward trends in specific conductance, calcium, magnesium, sodium, and chloride likely were related to regional patterns of population growth, increases in developed land, and decreases in forested lands. These upward trends are consistent with those observed in other areas in the United States that are undergoing urbanization. Sites that began the trend period with the highest specific conductance values also experienced the greatest increases, specifically, three tributaries to the upper New Hope arm of Jordan Lake. For several sites with strong trends in specific conductance, data were insufficient to assess trends in individual ions. Because elevated concentrations of different ions have varying implications for water treatment, agricultural use, and aquatic health, it could be beneficial to consistently monitor ion concentrations at additional locations in the study area.

Concentrations of nitrate and ammonia decreased in most stream sites; trends could not be determined at most lake sites. At Northeast Creek, nitrate plus nitrite concentrations decreased 75.5 percent and ammonia concentrations decreased 57.3 percent after an upstream wastewater-reclamation facility implemented nitrogen-removal practices. In contrast, concentrations of total organic nitrogen increased at most stream and lake sites throughout the study area, suggesting that broad, rather than site-specific, factors were responsible for the increase. Potential interactions between atmospheric and aquatic nitrogen cycling in the Triangle area are not well understood but warrant further research. Because trends for inorganic and organic nitrogen fractions often differed, trends in total nitrogen were not as informative as those computed for the individual nitrogen fractions. At nine sites, total-nitrogen trend directions and (or) magnitude changed significantly during the 25-year trend period. Monotonic trend tests would not have characterized these changes adequately. Total phosphorus concentrations decreased at most stream sites, suggesting that stream water quality in the Triangle area continues to benefit from the phosphate-detergent ban and wastewater-treatment upgrades that were implemented in the late 1980s and early 1990s. However, total phosphorus increased significantly at one formerly rural stream that underwent considerable increases in population density and land development. Trends in total phosphorus in Triangle lakes were mixed and generally not statistically significant; however, upward trends in Jordan Lake warrant continued monitoring.

Total suspended solids and suspended sediment decreased significantly at most stream sites in the study area. A comparison of trends for these two constituents was only possible for two stream sites. At both sites, trend directions for total suspended solids and suspended sediment were in agreement; however, trend magnitude was higher for suspended sediment.

Secchi transparency increased significantly at six lake sites, indicating that water clarity improved during 1993-2013. After step increases related to a laboratory method change were accounted for by the trend time-series analysis, significant downward trends in chlorophyll $a$ concentrations were noted for three lake sites, nonsignificant downward trends were noted for three additional lake sites, and nonsignificant upward trends were noted for the remaining two lake sites.

In addition to the regional trends described in this study, trends observed at individual sites also reflected the influence of local factors. For example, nutrient reductions were observed at three stream sites downstream from wastewaterreclamation facilities that implemented nutrient-removal processes. At another stream site, conservation efforts likely reduced nutrient inputs from nonpoint sources in the watershed. These improvements in water quality occurred at these four sites despite concurrent population growth and development. In contrast, nutrients and suspended sediment increased at a stream site in a formerly rural watershed that experienced tremendous development during the trend period. These indicators of deteriorating water quality at the site were likely related to hydrologic alteration and increased inputs from nonpoint sources.

Several important lessons were learned in the course of this study. Changes in sampling and laboratory methods may directly affect water-quality data and, thus, trend results. Method changes that are well documented by data-collection agencies and appropriately incorporated into trend analysis and other data-interpretation activities can benefit the resulting analyses. Data collected by different agencies can be highly complementary; for example, U.S. Geological Survey highflow samples and samples from rural streams supplement 
fixed-interval sampling conducted by the North Carolina Department of Environmental Quality, Upper Cape Fear River Basin Association, and Middle Cape Fear River Basin Association. Data from different agencies can be "harmonized" for use in a combined dataset provided assumptions about the data are verified. For long-term trend analysis, approaches that accommodate disparities in sampling frequency and data gaps are preferred, because sampling programs typically shift over time. Lastly, streamflow data are essential for interpreting water-quality data and typically benefit a wide audience of users. Streamgages, coupled with historical water-quality data, are "magnets" for supplemental monitoring and data-analysis efforts. Since the project began in late 1988, Triangle Area Water Supply Monitoring Project stream sites have been included in several regional and national studies, leveraging investments made by local project partners. It is important to continue the programs that have been put in place in the Triangle area to protect water supplies and to continue tracking water quality over time.

Results of this study suggest that the simple question, "Is water quality getting better or worse?" is overly simplistic, especially in areas that are rapidly changing like the Triangle area of North Carolina. Water quality is influenced by multiple, often confounding factors. Within similar timeframes, watersheds may experience increases in population, developed lands and impervious surfaces, groundwater and surface-water withdrawals, wastewater inputs, septic tank installations, and urban stormwater runoff. At the same time, open spaces and riparian buffers, urban and agricultural best management practices, wastewater-treatment improvements, and water-conservation measures may be implemented; and agricultural land uses may shift-for example, from row crops to pasture. Therefore, as long-term data become available for analysis, it has become apparent that water-quality changes are not uniform over time. Long-term monitoring and flexible analytical approaches are critical for determining how ongoing growth and development may affect water quality and for ensuring the resiliency of water supplies for the future.

\section{References Cited}

Bain, G.L., and Brown, C.E., 1981, Evaluation of the Durham Triassic basin of North Carolina and technique used to characterize its waste-storage potential: U.S. Geological Survey Open-File Report 80-1295, 132 p., accessed February 15, 2018, at https://pubs.usgs.gov/of/1980/1295/ report.pdf.

Cain, J.L., Harden, S.L., and Giorgino, M.J., 2018, Datasets for trends in water quality of selected streams and reservoirs used for water supply in the Triangle area of North Carolina, 1989-2013: U.S. Geological Survey data release, accessed May 11, 2018, at https://doi.org/10.5066/F7MS3S17.
Childress, C.J.O., and Bathala, N., 1997, Water-quality trends for streams and reservoirs in the Research Triangle area of North Carolina, 1983-95: U.S. Geological Survey WaterResources Investigations Report 97-4061, 18 p.

Cohn, T.A., and Lins, H.F., 2005, Nature's style-Naturally trendy: Geophysical Research Letters, v. 32, L23402, accessed June 27, 2017, at https://doi.org/10.1029/ 2005GL024476.

Cornell, S.E., 2011, Atmospheric nitrogen depositionRevisiting the question of the importance of the organic component: Environmental Pollution, v. 159, no. 10, p. 2214-2222. [Also available at https://doi.org/10.1016/ j.envpol.2010.11.014.]

Daniel, C.C., III, and Dahlen, P.R., 2002, Preliminary hydrogeologic assessment and study plan for a regional ground-water resource investigation of the Blue Ridge and Piedmont Provinces of North Carolina: U.S. Geological Survey Water-Resources Investigations Report 2002-4105, 60 p., accessed April 11, 2018, at https://pubs.er.usgs.gov/ publication/wri024105.

Dugan, H.A., Bartlett, S.L., Burke, S.M., Doubek, J.P., Krivak-Tetley, F.E., Skaff, N.K., Summers, J.C., Farrell, K.J., McCullough, I.M., Morales-Williams, A.M., Roberts, D.C., Ouyang, Z., Scordo, F., Hanson, P.C., and Weathers, K.C., 2017, Salting our freshwater lakes: Proceedings of the National Academy of Sciences, v. 114, no. 7, p. 4453-4458, accessed March 1, 2018, at https://doi.org/10.1073/ pnas. 1620211114 .

Forstall, R.L., 1996, Population of states and counties of the United States-1790 to 1990: U.S. Bureau of the Census, 225 p. [Also available at https://www.census.gov/ population/www/censusdata/pop1790-1990.html.]

Galloway, J.N., and Cowling, E.B., 2002, Reactive nitrogen and the world - 200 years of change: AMBIO-A Journal of the Human Environment, v. 31, no. 2, p. 64-71.

Gray, J.R., Glysson, G.D., Turcios, L.M., and Schwarz, G.E., 2000, Comparability of suspended-sediment concentration and total suspended solids data: U.S. Geological Survey Water-Resources Investigations Report 00-4191, 14 p.

Harden, S.L., Cuffney, T.F., Terziotti, S., and Kolb, K.R., 2013, Relation of watershed setting and stream nutrient yields at selected sites in central and eastern North Carolina, 1997-2008: U.S. Geological Survey Scientific Investigations Report 2013-5007, 47 p., accessed February 23, 2018, at https://pubs.usgs.gov/sir/2013/5007/.

Helsel, D.R., 2005, Nondetects and data analysis-Statistics for censored environmental data: Hoboken, N.J., Wiley Interscience, John Wiley \& Sons, Inc., 250 p. 
Helsel, D.R., and Hirsch, R.M., 2002, Statistical methods in water resources: U.S. Geological Survey Techniques of Water-Resources Investigations, book 4, chap. A3, 510 p.

Hirsch, R.M., 2011, A perspective on nonstationarity and water management: Journal of the American Water Resources Association, v. 47, no. 3, p. 436-446.

Hirsch, R.M., and De Cicco, L.A., 2015, User guide to exploration and graphics for RivEr Trends (EGRET) and dataRetrieval - R packages for hydrologic data (version 2.0, February 2015): U.S. Geological Survey Techniques and Methods, book 4, chap. A10, 93 p., accessed February 16, 2018, at https://doi.org/10.3133/tm4A10.

Hirsch, R.M., Moyer, D.L., and Archfield, S.A., 2010, Weighted regressions on time, discharge, and season (WRTDS), with an application to Chesapeake Bay River inputs: Journal of the American Water Resources Association, v. 46, no. 5, p. 857-880, accessed April 19, 2018, at https://doi.org/10.1111/j.1752-1688.2010.00482.x.

Hirsch, R.M., and Slack, J.R., 1984, A nonparametric trend test for seasonal data with serial dependence: Water Resources Research, v. 20, no. 6, p. 727-732.

Holland, E.A., Braswell, B.H., Sulzman, J., and Lamarque, J.-F., 2005, Nitrogen deposition onto the United States and Western Europe-Synthesis of observations and models: Ecological Applications, v. 15, no. 1, p. 38-57.

Homer, C.G., Dewitz, J.A., Yang, L., Jin, S., Danielson, P., Xian, G., Coulston, J., Herold, N.D., Wickham, J.D., and Megown, K., 2015, Completion of the 2011 National Land Cover Database for the conterminous United StatesRepresenting a decade of land cover change information: Photogrammetric Engineering and Remote Sensing, v. 81 , no. 5, p. 345-354, accessed June 22, 2017, at https://www.mrlc.gov/nlcd2011.php.

Huffman, B.A., Pfeifle, C.A., Chapman, M.J., Bolich, R.E., Campbell, T.R., Geddes, D.J., Jr., and Pippin, C.G., 2006, Compilation of water-resources data and hydrogeologic setting for four research stations in the Piedmont and Blue Ridge Physiographic Provinces of North Carolina: U.S. Geological Survey Open-File Report 2006-1168, 102 p., accessed April 20, 2018, at https://pubs.usgs.gov/ of/2006/1168/.

Jickells, T., Baker, A.R., Cape, J.N., Cornell, S.E., and Nemitz, E., 2013, The cycling of organic nitrogen through the atmosphere: Philosophical Transactions of the Royal Society B, Biological Sciences, v. 368, accessed February 25, 2018, at https://doi.org/10.1098/rstb.2013.0115.
Kaushal, S.S., Duan, S., Doody, T.R., Haq, S., Smith, R.M., Newcomer Johnson, T.A., Delaney Newcomb, K., Gorman, J., Bowman, N., Mayer, P.M., Wood, K.L., Belt, K.T., and Stack, W.P., 2017, Human-accelerated weathering increases salinization, major ions, and alkalinization in fresh water across land use: Applied Geochemistry, v. 83, p. 121-135, accessed July 10, 2017, at https://doi.org/10.1016/ j.apgeochem.2017.02.006.

Kendall, M.G., 1938, A new measure of rank correlation: Biometrika, v. 30, no. 1/2, p. 81-93.

Li, Y., Schichtel, B.A., Walker, J.T., Schwede, D.B., Chen, X., Lehmann, C.M.B., Puchalski, M.A., Gay, D.A., and Collett, J.L., Jr., 2016, Increasing importance of deposition of reduced nitrogen in the United States: Proceedings of the National Academy of Sciences, v. 113, no. 21, p. 5874-5879, accessed February 24, 2018, at https://doi.org/10.1073/pnas.1525736113.

Lins, H.F., and Cohn, T.A., 2011, Stationarity-Wanted dead or alive?: Journal of the American Water Resources Association, v. 47, no. 3, p. 475-480, accessed April 25, 2018, at https://doi.org/10.1111/j.1752-1688.2011.00542.x.

Liu, X., Zhang, Y., Han, W., Tang, A., Shen, J., Cui, Z., Vitousek, P., Erisman, J.W., Goulding, K., Christie, P., Fangmeier, A., and Zhang, F., 2013, Enhanced nitrogen deposition over China: Nature, v. 494, p. 459-462, accessed April 25, 2018, at https://doi.org/10.1038/nature11917.

McDonald, R.I., Weber, K.F., Padowski, J., Boucher, T., and Shemie, D., 2016, Estimating watershed degradation over the last century and its impact on water-treatment costs for the world's large cities: Proceedings of the National Academy of Sciences, v. 113, no. 32, p. 9117-9122, accessed April 25, 2018, at https://doi.org/10.1073/pnas.1605354113.

Moore, J., Bird, D.L., Dobbis, S.K., and Woodward, G., 2017 , Nonpoint source contributions drive elevated major ion and dissolved inorganic carbon concentrations in urban watersheds: Environmental Science and Technology Letters, v. 4, no. 6, p. 198-204, accessed July 10, 2017 , at https://doi.org/10.1021/acs.estlett.7b00096.

National Oceanic and Atmospheric Administration [NOAA], 2016, Climate divisions with counties: National Weather Service, Climate Prediction Center website, accessed June 28, 2016, at http:/www.cpc.noaa.gov/products/ analysis_monitoring/regional_monitoring/CLIM_DIVS/ states_counties_climate-divisions.shtml.

National Oceanic and Atmospheric Administration [NOAA], 2017, Data tools - 1981-2010 normals: National Centers for Environmental Information website, accessed June 29, 2017, at https://www.ncdc.noaa.gov/cdo-web/datatools/ normals. 
National Oceanic and Atmospheric Administration [NOAA], 2018, Climate at a glance: National Centers for Environmental Information website, accessed April 12, 2018, at https:/www.ncdc.noaa.gov/cag/divisional/time-series.

North Carolina Department of Environmental Quality, 2014, 2014 North Carolina water quality assessment for 305(b): North Carolina Department of Environmental Quality, Integrated Report Files website, 2014 Integrated Report, accessed February 7, 2018, at https://files.nc.gov/ncdeq/ Water\%20Quality/Planning/TMDL/303d/2014v2/2014_ NC_WQ_Asmnt2.16.15.pdf.

North Carolina Department of Environmental Quality, 2017, Important information for users of NC DWR ambient water quality monitoring data, August 2017, version 2.6: North Carolina Department of Environmental Quality website, accessed February 12, 2018, at https://files.nc.gov/ncdeq/ Water\%20Quality/Environmental\%20Sciences/ECO/ AMS_Data_Explanations_v2_6.pdf.

North Carolina Department of Environmental Quality, 2018, River basin classification schedule: North Carolina Department of Environmental Quality website, accessed February 7, 2018, at https://deq.nc.gov/river-basinclassification-schedule.

North Carolina Department of Health and Human Services, 2018, Is your well-water safe?: North Carolina Department of Health and Human Services, accessed June 7, 2018, at http://epi.publichealth.nc.gov/oee/docs/wellwater.pdf.

North Carolina Department of Natural Resources and Community Development, 1987, Eno River area capacity use investigation, executive summary: Raleigh, N.C., Division of Water Resources, $34 \mathrm{p}$.

North Carolina Office of State Budget and Management, 2017, Population overview, 2010-2036: North Carolina Office of State Budget and Management, accessed February 13, 2017, at https://ncosbm.s3.amazonaws.com/s3fs-public/demog/ countytotals_populationoverview.html.

Oblinger, C.J., 2004, Triangle Area Water Supply Monitoring Project, October 1988 through September 2001, North Carolina-Description of the water-quality network, sampling and analysis methods, and quality-assurance practices: U.S. Geological Survey Open-File Report 2004-1278, 56 p., accessed April 25, 2018, at https://pubs.usgs.gov/ of $/ 2004 / 1278 /$.
Oelsner, G.P., Sprague, L.A., Murphy, J.C., Zuellig, R.E., Johnson, H.M., Ryberg, K.R., Falcone, J.A., Stets, E.G., Vecchia, A.V., Riskin, M.L., De Cicco, L.A., Mills, T.J., and Farmer, W.H., 2017, Water-quality trends in the Nation's rivers and streams, 1972-2012-Data preparation, statistical methods, and trend results: U.S. Geological Survey Scientific Investigations Report 2017-5006, 136 p., accessed February 16, 2018, at https://doi.org/10.3133/ sir20175006.

Samy, S., Robinson, J., Rumsey, I.C., Walker, J.T., and Hays, M.D., 2013, Speciation and trends of organic nitrogen in Southeastern U.S. fine particulate matter (PM2.5): Journal of Geophysical Research-Atmospheres, v. 118, p. 1996-2006, accessed February 24, 2018, at https://doi.org/10.1029/2012JD017868.

Sprague, L.A., Mueller, D.K., Schwarz, G.E., and Lorenz, D.L., 2009, Nutrient trends in streams and rivers of the United States, 1993-2003: U.S. Geological Survey Scientific Investigations Report 2008-5202, 196 p., accessed February 26, 2018, at https://pubs.usgs.gov/sir/2008/5202/.

Spruill, T.B., Jen, P.S., and Rasmussen, R.B., 2006, Suspended sediment and nutrients in the upper Cape Fear River Basin, North Carolina, 2002-04, with an analysis of temporal changes, 1976-2004: U.S. Geological Survey Scientific Investigations Report 2005-5271, 40 p., accessed June 15, 2017, at https://pubs.usgs.gov/sir/2005/5271/pdf/report.pdf.

Thornton, J., Steel, A., and Rast, W., 1996, Reservoirs, chap. 8 of Chapman, D. (ed.), Water quality assessments-A guide to use of biota, sediments and water in environmental monitoring: UNESCO/WHO/UNEP, 41 p., accessed February 22, 2018, at http:/www.who.int/water sanitation_health/resourcesquality/wqachapter8.pdf.

U.S. Army Corps of Engineers, 2018, B. Everett Jordan-Cape Fear River Basin, daily elevation, inflow and outflow data: Wilmington District Water Management web interface, accessed February 14, 2018, at http://epec.saw.usace.army. mil/jord.htm.

U.S. Census Bureau, 2017, American FactFinder: U.S. Census Bureau website, accessed February 13, 2017 , at https://factfinder.census.gov/faces/nav/jsf/pages/ index.xhtml.

U.S. Environmental Protection Agency, 2014, STORET Central Warehouse: U.S. Environmental Protection Agency web interface, accessed August 20, 2014, at https://ofmpub.epa.gov/storpubl/dw_pages.querycriteria.

U.S. Geological Survey, 2014, USGS water data for the Nation: U.S. Geological Survey National Water Information System database, accessed September 17, 2014, at https://doi.org/10.5066/F7P55KJN. 
Vecchia, A.V., 2000, Water-quality trend analysis and sampling design for the Souris River, Saskatchewan, North Dakota, and Manitoba: U.S. Geological Survey Water-Resources Investigations Report 00-4019, 77 p., accessed April 25, 2018, at http://nd.water.usgs.gov/pubs/wri/wri004019/.

Vecchia, A.V., 2003, Water-quality trend analysis and sampling design for streams in North Dakota, 1971-2000: U.S. Geological Survey Water-Resources Investigations Report 03-4094, 73 p., accessed June 26, 2017, at http://nd.water.usgs.gov/pubs/wri/wri034094/.

Vecchia, A.V., 2004a, Using time series analysis to analyze trends in concentration: Proceedings of the National Monitoring Conference, Chattanooga, Tenn., May 17-20, 2004, 19 p., accessed April 25, 2018, at https://acwi.gov/ monitoring/conference/2004/.

Vecchia, A.V., 2004b, Statistical techniques for trend and load estimation: Proceedings of the National Monitoring Conference, Chattanooga, Tenn., May 17-20, 2004, 74 p., accessed April 25, 2018, at https://acwi.gov/monitoring/ conference/2004/.
Vecchia, A.V., 2005, Water-quality trend analysis and sampling design for streams in the Red River of the North Basin, Minnesota, North Dakota, and South Dakota, 1970-2001: U.S. Geological Survey Scientific Investigations Report 2005-5224, 54 p., accessed September 16, 2015, at http://pubs.usgs.gov/sir/2005/5224/.

Vogelmann, J.E., Howard, S.M., Yang, L., Larson, C.R., Wylie, B.K., and Van Driel, J.N., 2001, Completion of the 1990's National Land Cover Data Set for the conterminous United States: Photogrammetric Engineering and Remote Sensing, v. 67, p. 650-662, accessed June 22, 2017, at https://www.mrlc.gov/nlcd1992.php.

Weaver, J.C., 2016, Low-flow characteristics and flowduration statistics for selected USGS continuous-record streamgaging stations in North Carolina through 2012 (ver. 1.1, March 2016): U.S. Geological Survey Scientific Investigations Report 2015-5001, 89 p., accessed June 27, 2017, at https://doi.org/10.3133/sir20155001.

Weaver, J.C., Terziotti, S., Kolb, K.R., and Wagner, C.R., 2012, StreamStats in North Carolina - A water-resources web application: U.S. Geological Survey Fact Sheet 2012-3137, 4 p., accessed April 25, 2018, at https://pubs.usgs.gov/fs/2012/3137/. 
Manuscript was approved on June 5, 2018

Publishing support was provided by the USGS Science Publishing Network, Reston Publishing Service Center

For additional information, contact

Director, South Atlantic Water Science Center

U.S. Geological Survey

720 Gracern Road

Stephenson Center, Suite 129

Columbia, SC 29210

Or visit the South Atlantic Water Science Center website at https://www.usgs.gov/water/southatlantic/ 


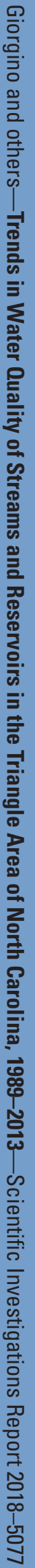

